\title{
International Low Level Waste Disposal Practices and Facilities
}

Fuel Cycle Research \& Development






\section{DISCLAIMER}

This information was prepared as an account of work sponsored by an agency of the U.S. Government. Neither the U.S. Government nor any agency thereof, nor any of their employees, makes any warranty, expressed or implied, or assumes any legal liability or responsibility for the accuracy, completeness, or usefulness, of any information, apparatus, product, or process disclosed, or represents that its use would not infringe privately owned rights. References herein to any specific commercial product, process, or service by trade name, trade mark, manufacturer, or otherwise, does not necessarily constitute or imply its endorsement, recommendation, or favoring by the U.S. Government or any agency thereof. The views and opinions of authors expressed herein do not necessarily state or reflect those of the U.S. Government or any agency thereof. 


\section{FCT Quality Assurance Program Document}

\section{Appendix E \\ FCT Document Cover Sheet}

Name/Title of Deliverable/Milestone

Work Package Title and Number

Work Package WBS Number

Responsible Work Package Manager

Date Submitted

Deliverable/Milestone

$\square$ QRL-3

This deliverable was prepared in accordance with

International Low Level Waste Disposal Practices and Facilities / M41UF030301

Perspectives in Nuclear Waste Management / FTAN11UF0303

\subsubsection{3}

W. Mark Nutt (electronic signature)

(Name/Signature)

QA program which meets the requirements of

$\bigotimes$ DOE Order 414.1

$\square$ NQA-1-2000

This Deliverable was subjected to:

$\square$ Technical Review

Technical Review (TR)

Review Documentation Provided

Signed TR Report or,

Signed TR Concurrence Sheet or,

Signature of TR Reviewer(s) below

Name and Signature of Reviewers

Peer Review

Peer Review (PR)

Review Documentation Provided

Signed PR Report or,

Signed PR Concurrence Sheet or,

Signature of PR Reviewer(s) below

*Note: In some cases there may be a milestone where an item is being fabricated, maintenance is being performed on a facility, or a document is being issued through a formal document control process where it specifically calls out a formal review of the document. In these cases, documentation (e.g., inspection report, maintenance request, work planning package documentation or the documented review of the issued document through the document control process) of the completion of the activity along with the Document Cover Sheet is sufficient to demonstrate achieving the milestone. QRL for such milestones may be also be marked N/A in the work package provided the work package clearly specifies the requirement to use the Document Cover Sheet and provide supporting documentation. 


\section{CONTENTS}

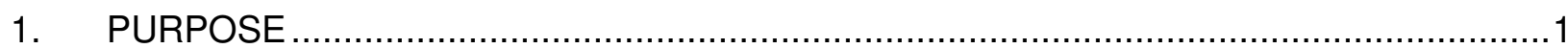

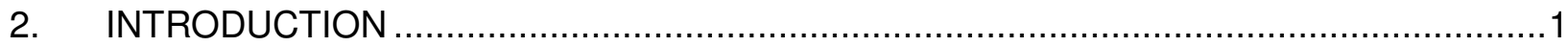

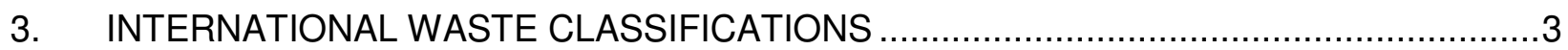

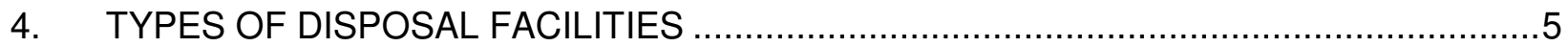

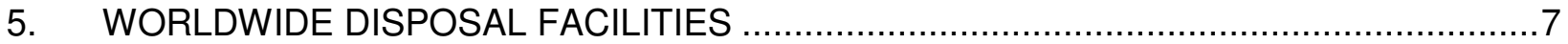

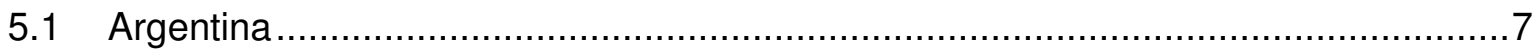

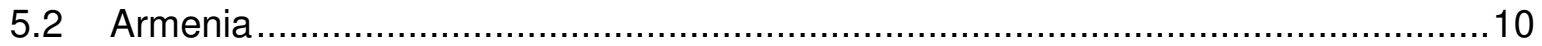

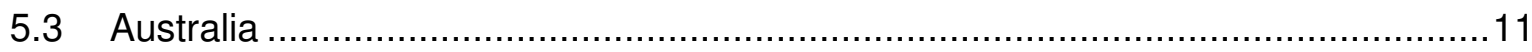

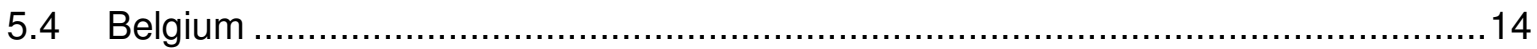

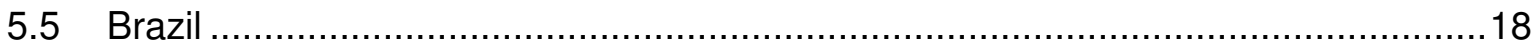

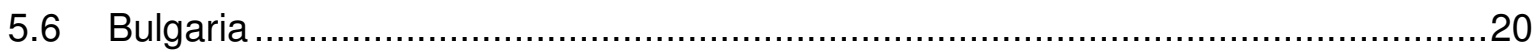



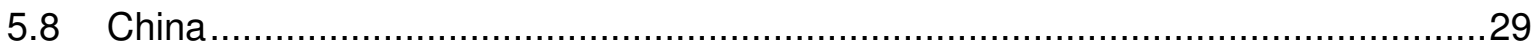

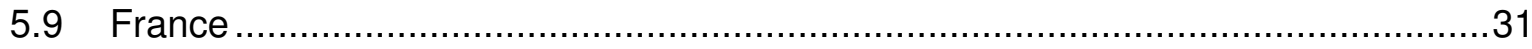

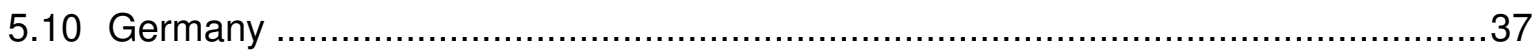

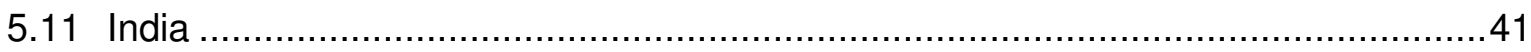

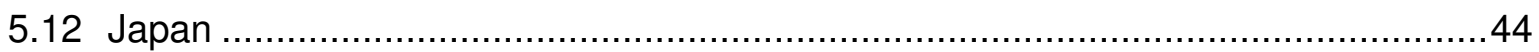



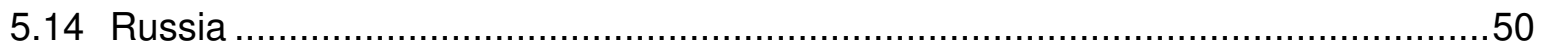

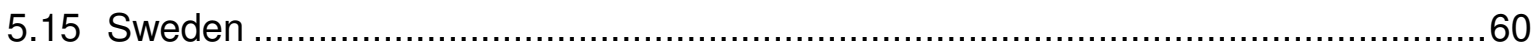

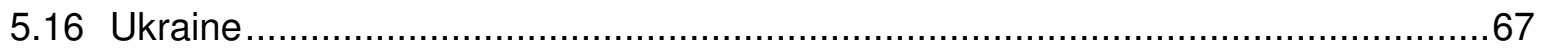

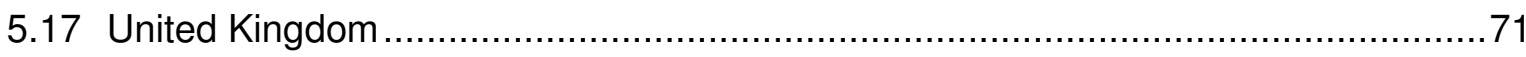

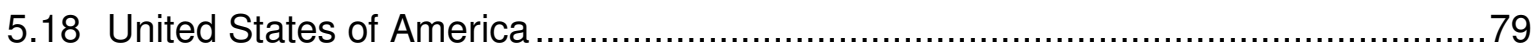

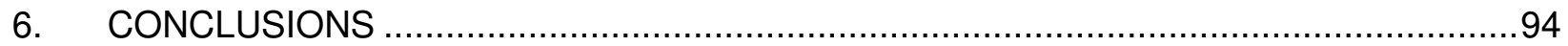

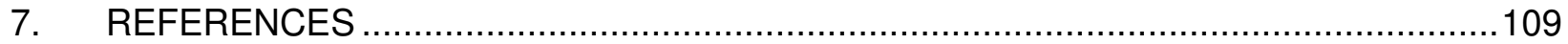




\section{FIGURES}

Figure 1. United Nations Classification of the World in Regions ....................................... 3

Figure 2. Conceptual Illustration of the IAEA Waste Classification Scheme ............................ 1



Figure 4. Diagram and picture of trench type used for the disposal of solid LLW at the

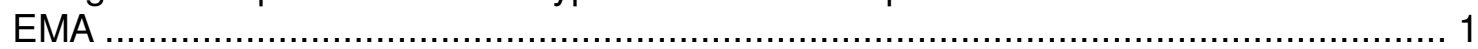

Figure 5. Illustrative design approaches for Austrailian LILW disposal facilities..................... 1

Figure 6. Diagram of Disposal Shaft at Mt Walton East IWDF ...................................... 1

Figure 7. Cross-section of concrete monolithic blocks at Dessel facility ............................... 1

Figure 8. Illustration of the Dessel LLW surface disposal facility after permanent closure ......... 1

Figure 9. Dessel surface disposal facility................................................................ 1

Figure 10. Angra 1, 2 radioactive waste interim storage facilities ..................................... 1

Figure 11. Temporary storage at Abadia de Goiás ....................................................... 1

Figure 12. Repositories at Abadia de Goiás post-closure ............................................... 1

Figure 13. RCC placement in warehouse storage at the Kozloduy NPP ............................... 1

Figure 14. Temporary storage facilities at Novi Han ..................................................... 1

Figure 15. Positioning of disposal modules and chambers at the proposed Radiana

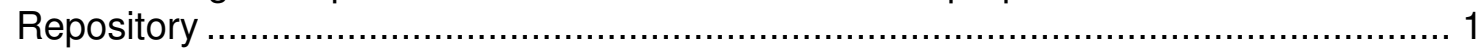

Figure 16. Overhead and cross sectional view of disposal chamber and RCC placement......... 1

Figure 18. Western Waste Management Facility .......................................................... 1

Figure 19. Modular above-ground storage (MAGS) structure at CRL ................................ 1

Figure 20. Proposed Deep Geologic Repository for L\&ILW on the BNPD Site ....................... 1

Figure 21. Conceptual design for the Port Hope Project at the site of WWMF ...................... 1

Figure 22. Conceptual design for the Port Granby Project ........................................... 1

Figure 23. Waste package placement and mound closure coverings at Centre de la Manche LILW Repository ........................................................................... 1

Figure 24. Centre de la Manche LILW Repository ........................................................ 1

Figure 25. Centre de l'Aube LILW Repository ............................................................... 1

Figure 27. Concrete disposal vaults at the Centre de l'Aube LILW Repository ........................ 1

Figure 26. Facility Layout for the CSTFA in France ....................................................... 1

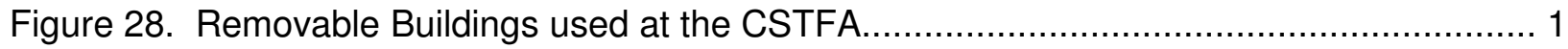

Figure 29. Cross Section of a VLLW Disposal Cell at the CSTFA ..................................... 1

Figure 30. Comparison of German and IAEA waste classification schemes .......................... 1

Figure 31. Stacked LLW drums at the Morsleben LILW Repository..................................... 1

Figure 32. Salt-lined chamber at the Asse Research Mine ................................................ 1 
Figure 33. Disorganized piles of nuclear waste lie untouched since their disposal …….......... 1

Figure 34. Typical schematic diagram of reinforced concrete trench at a NSDF in India ........... 1

Figure 35. Typical construction details of tile hole and shielding plug at a NSDF in India .......... 1

Figure 36. Workers at a nuclear plant disposing of LLW drums in Japan ............................... 1

Figure 37: JNPL LLW Disposal Facility Structures ........................................................ 1

Figure 38: Waste packages are stacked inside disposal facility by crane …............................. 1

Figure 39. LLW Disposal Center at the JNFL site in Rokkasho ............................................ 1

Figure 40. Wolsong LILW Disposal Center site in Gyeongju .................................................. 1

Figure 41. Conceptual drawing of the post-closure disposal silo ............................................ 1

Figure 42. Floating reactor compartments awaiting long-term storage in Sayda Bay ................. 1

Figure 43. Overview of the Sayda Bay long-term storage facility conceptual design and

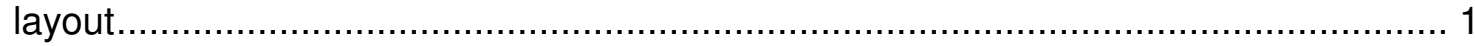

Figure 44. Reactor compartments on land at the interim storage facility in Sayda Bay .............. 1

Figure 45. Envisioned Sayda Bay disposal Centre at the current location of the long-



Figure 46. Sayda Bay construction site as of October 2009 ............................................. 1

Figure 47. Evolution of reservoirs at the Mayak site ……................................................. 1

Figure 48. Satellite view of the Mayak site ……............................................................. 1

Figure 49. Underground injection sites at Seversk ……................................................. 1

Figure 50. The M/S Sigyn - SKB's custom built nuclear waste ship ................................... 1

Figure 51. Different types of waste containers for LILW .................................................... 1

Figure 52. Placement of radioactive waste in the silo and rock vaults ................................... 1

Figure 53. Swedish final repository (SFR) for short lived LILW at Forsmark .......................... 1

Figure 54. Shallow land burial at Oskarshamn .......................................................... 1

Figure 55. ENSDF at the Vektor Complex in the Chernobyl exclusion zone .......................... 1

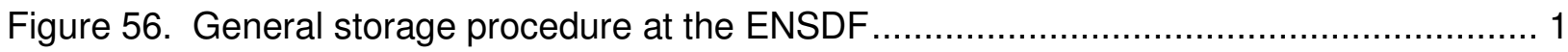

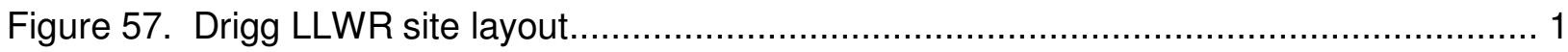



Figure 59. 12 component layered cap for the LLWR ……................................................. 1

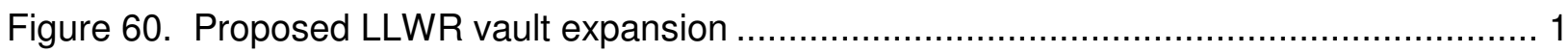

Figure 61. Conceptual diagrams of Dounreay LLW disposal vaults during operation and



Figure 62. Current Dounreay nuclear site and proposed location of the new LLW

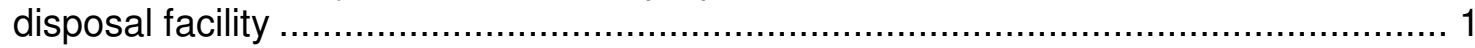

Figure 63. Commercial Disposal Facilities and LLW Interstate Compacts ................................ 1

Figure 64. DOE Low-Level and Mixed Low-Level Disposal Facilities ...................................... 1 


\section{TABLES}

Table 1. Nuclear Power Reactors in the World ............................................................. 2

Table 2. US Commercial Radioactive Waste Classification ............................................ 81

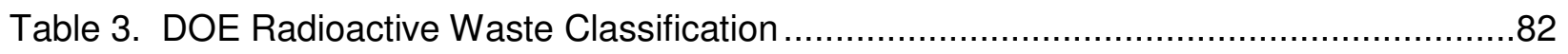

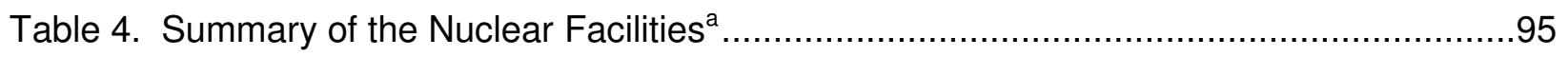

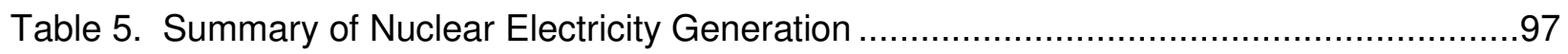

Table 6. Summary of international Waste Management Practice, Facilities, and

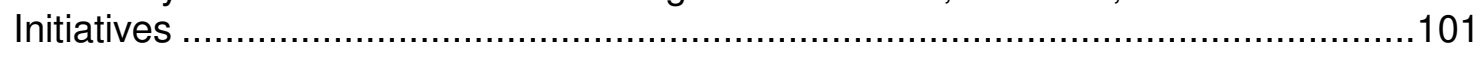





\section{USED FUEL DISPOSITION CAMPAIGN INTERNATIONAL LOW LEVEL WASTE DISPOSAL PRACTICES AND FACILITIES}

\section{PURPOSE}

The safe management of nuclear waste arising from nuclear activities is an issue of great importance for the protection of human health and the environment now and in the future. The primary goal of this report is to identify the current situation and practices being utilized across the globe to manage and store low and intermediate level radioactive waste. The countries included in this report were selected based on their nuclear power capabilities and involvement in the nuclear fuel cycle. This report highlights the nuclear waste management laws and regulations, current disposal practices, and future plans for facilities of the selected international nuclear countries. For each country presented, background information and the history of nuclear facilities are also summarized to frame the country's nuclear activities and set stage for the management practices employed.

\section{INTRODUCTION}

The production of nuclear energy, including all the steps in the nuclear fuel cycle, results in the generation of radioactive waste. However, radioactive waste may also be generated by other activities such as medical, laboratory, research institution, or industrial use of radioisotopes and sealed radiation sources, defense and weapons programs, and processing (mostly large scale) of mineral ores or other materials containing naturally occurring radionuclides. Radioactive waste also arises from intervention activities, which are necessary after accidents or to remediate areas affected by past practices (IAEA 2009b; IAEA 2007).

The radioactive waste generated arises in a wide range of physical, chemical, and radiological forms. It may be solid, liquid, or gaseous. Levels of activity concentration can vary from extremely high, such as levels associated with spent fuel and residues from fuel reprocessing, to very low, for instance those associated with radioisotope applications. Equally broad is the spectrum of half-lives of the radionuclides contained in the waste (IAEA 2009b).

These differences result in an equally wide variety of options for the management of radioactive waste. There is a variety of alternatives for processing waste and for short term or long term storage prior to disposal. Likewise, there are various alternatives currently in use across the globe for the safe disposal of waste, ranging from near surface to geological disposal, depending on the specific classification of the waste (see the following section for more details regarding international waste classifications).

At present, there appears to be a clear and unequivocal understanding that each country is ethically and legally responsible for its own wastes, in accordance with the provisions of the Joint Convention on the Safety of Spent Fuel Management and on the Safety of Radioactive Waste Management (Soda et al. 2009). Therefore the default position is that all nuclear wastes will be disposed of in each of the 40 or so countries concerned with nuclear power generation or part of the fuel cycle (WNA 2011c). To illustrate the global distribution of radioactive waste now and in the near future, Table 1 provides the regional breakdown, based on the UN classification 
of the world in regions illustrated in Figure 1, of nuclear power reactors in operation and under construction worldwide (IAEA 2011b). In summary, 31 countries operate 433 plants, with a total capacity of more than 365 gigawatts of electrical energy (GW[e]). A further 65 units, totaling nearly $63 \mathrm{GW}(\mathrm{e})$, are under construction across 15 of these nations. In addition, 65 countries are expressing new interest in, considering, or actively planning for nuclear power to help address growing energy demands to fuel economic growth and development, climate change concerns, and volatile fossil fuel prices. Of these 65 new countries, 21 are in Asia and the Pacific region, 21 are from the Africa region, 12 are in Europe (mostly Eastern Europe), and 11 in Central and South America. However, 31 of these 65 are not currently planning to build reactors, and 17 of those 31 have grids of less than $5 \mathrm{GW}$, which is said to be too small to accommodate most of the reactor designs available. For the remaining 34 countries actively planning reactors, as of September 2010: 14 indicate a strong intention to precede with introduction of nuclear power; 7 are preparing but haven't made a final decision, 10 have made a decision and are preparing infrastructure, 2 have ordered a new nuclear power plant, and 1 has a plant under construction (WNA 2011b; IAEA 2010).

In all countries interested in pursuing nuclear power, it is necessary for the governments to create an environment for investment and advancement of nuclear power, including development of a professional and independent regulatory framework and regime, knowledge and refinement of skills in nuclear safety and control, definition of policies on nuclear waste management and decommissioning, and participation in international non-proliferation measures. Specifically related to radioactive waste management, nuclear facilities and industries that utilize radioactive material work to well-established safety standards for the management of their waste.

Table 1. Nuclear Power Reactors in the World

\begin{tabular}{|c|c|c|c|c|}
\hline Region & $\begin{array}{c}\text { In } \\
\text { Operation }\end{array}$ & $\begin{array}{c}\text { Under } \\
\text { Construction }\end{array}$ & $\begin{array}{l}\text { Long-term } \\
\text { Shutdown }^{\text {a }}\end{array}$ & $\begin{array}{l}\text { Permanent } \\
\text { Shutdown }\end{array}$ \\
\hline \multicolumn{5}{|l|}{ Africa } \\
\hline Southern Africa & 2 & - & - & - \\
\hline \multicolumn{5}{|l|}{ America } \\
\hline Central America & 2 & - & - & - \\
\hline North America & 122 & 1 & 4 & 31 \\
\hline South America & 4 & 2 & & \\
\hline \multicolumn{5}{|l|}{ Asia } \\
\hline Eastern Asia & 92 & 36 & 1 & 9 \\
\hline Southern Asia & 24 & 7 & - & - \\
\hline Western Asia & 1 & - & - & 1 \\
\hline \multicolumn{5}{|l|}{ Europe } \\
\hline Eastern Europe & 65 & 17 & - & 16 \\
\hline Northern Europe & 32 & 1 & - & 32 \\
\hline Southern Europe & 9 & - & - & 6 \\
\hline Western Europe & 80 & 1 & - & 42 \\
\hline World & 433 & 65 & 5 & 138 \\
\hline
\end{tabular}

a Long-term shutdown: units that have been shut down for an extended period (usually several years) without any firm recovery schedule at the beginning, but with the intention to eventually re-start. 


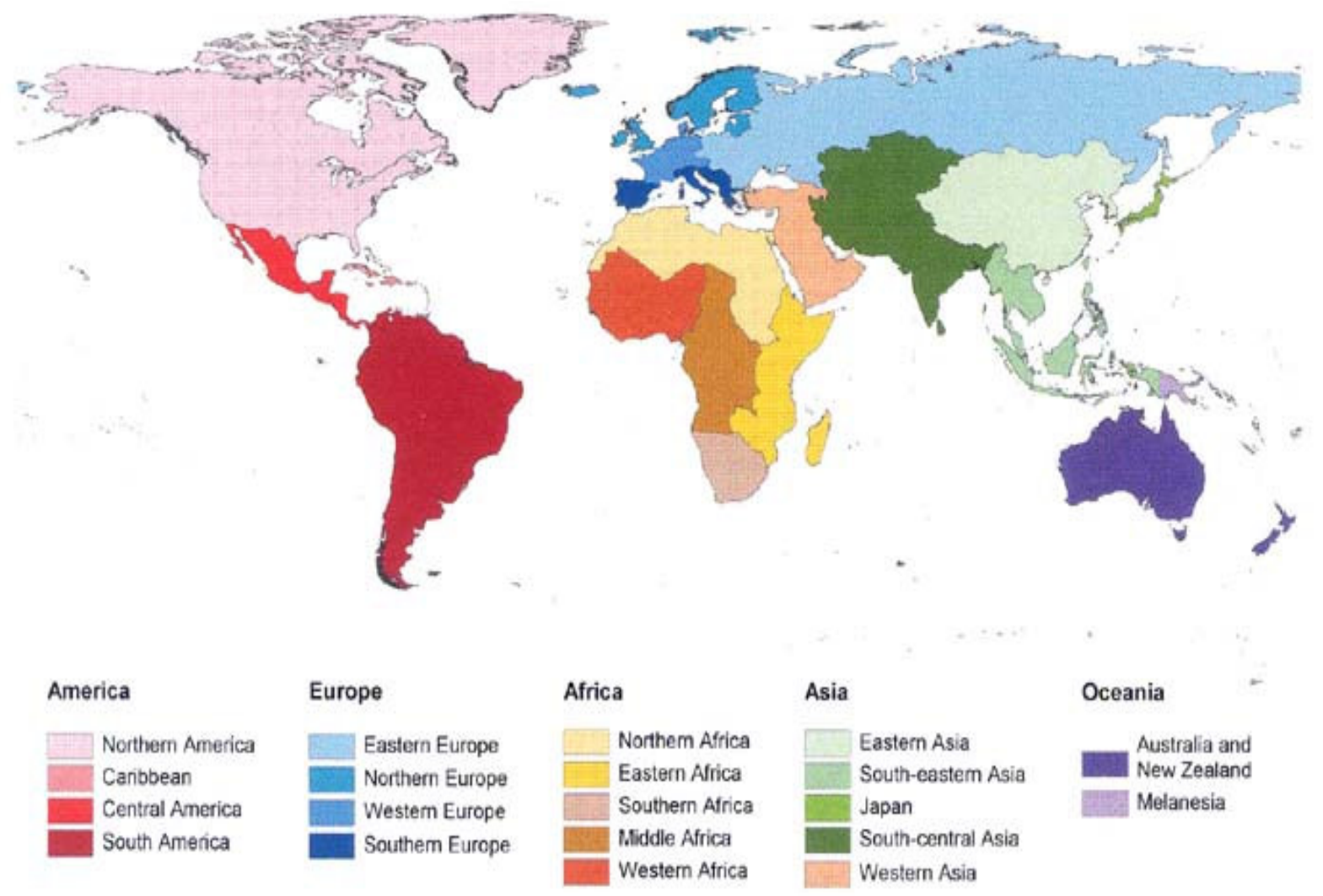

Figure 1. United Nations Classification of the World in Regions (FAO 2005)

International and regional organizations, such as the International Atomic Energy Agency (IAEA), the Nuclear Energy Agency (NEA) of the Organization for Economic Co-operation and Development (OECD), the European Commission (EC) and the International Commission on Radiological Protection (ICRP), develop standards, guidelines, agreements, directives, and recommendations under a framework of co-operation to assist countries in establishing and maintaining national standards. National policies, legislation, and regulations are all developed from these internationally agreed standards, guidelines, and recommendations. Amongst others, these standards aim to ensure the protection of the public and the environment, both now and into the future (WNA 2011b; WNA 2011v; IAEA 2009b).

\section{INTERNATIONAL WASTE CLASSIFICATIONS}

A classification scheme is of particular importance for the management of radioactive waste arising from the nuclear fuel cycle and decommissioning of nuclear facilities. Unfortunately, the global nuclear industry has not reached a consensus about a uniform waste classification system with unambiguous standards. A widely used classification system based on dose rates identifies waste as one of three levels: low, intermediate, or high (HLW). However, for the long term management of radioactive waste, it may be more practical to employ a classification based on the activity levels and longevity (or half-life) of radioactive constituents in the waste (IAEA 2007). 
A conceptual illustration of a waste classification scheme, as defined by the IAEA and adopted by many countries, is presented in Figure 2 (IAEA 2009b). This scheme divides waste into six different categories. The horizontal axis represents the half-life of the radionuclides contained in the waste, which can range from seconds to millions of years. In terms of radioactive waste safety, a radionuclide with a half-life of less than about 30 years is considered to be short lived. The vertical axis represents the activity content of the waste (in becquerel per gram $[\mathrm{Bq} / \mathrm{g}]$ ), which can range from negligible to very high. At the lower range of the vertical axis, below clearance levels, the management of the waste can be carried out without consideration of its radiological properties. At the very high end of the activity range includes very high concentrations of radionuclides or very high specific activity. The higher the activity content, the greater the need to contain and isolate the waste.

Limitations placed on the activity (total, specific, or activity concentration of waste that can be disposed of in a given disposal facility will depend on the radiological, chemical, physical and biological properties of the waste and on the particular radionuclides it contains. As can be seen from Figure 2, in some cases, the amount of activity, rather than activity concentration, may be used to determine the class of the waste. For example, waste containing only very small amounts of certain radionuclides (e.g., low energy beta emitters) may be excluded or cleared from regulatory control (IAEA 2009b).

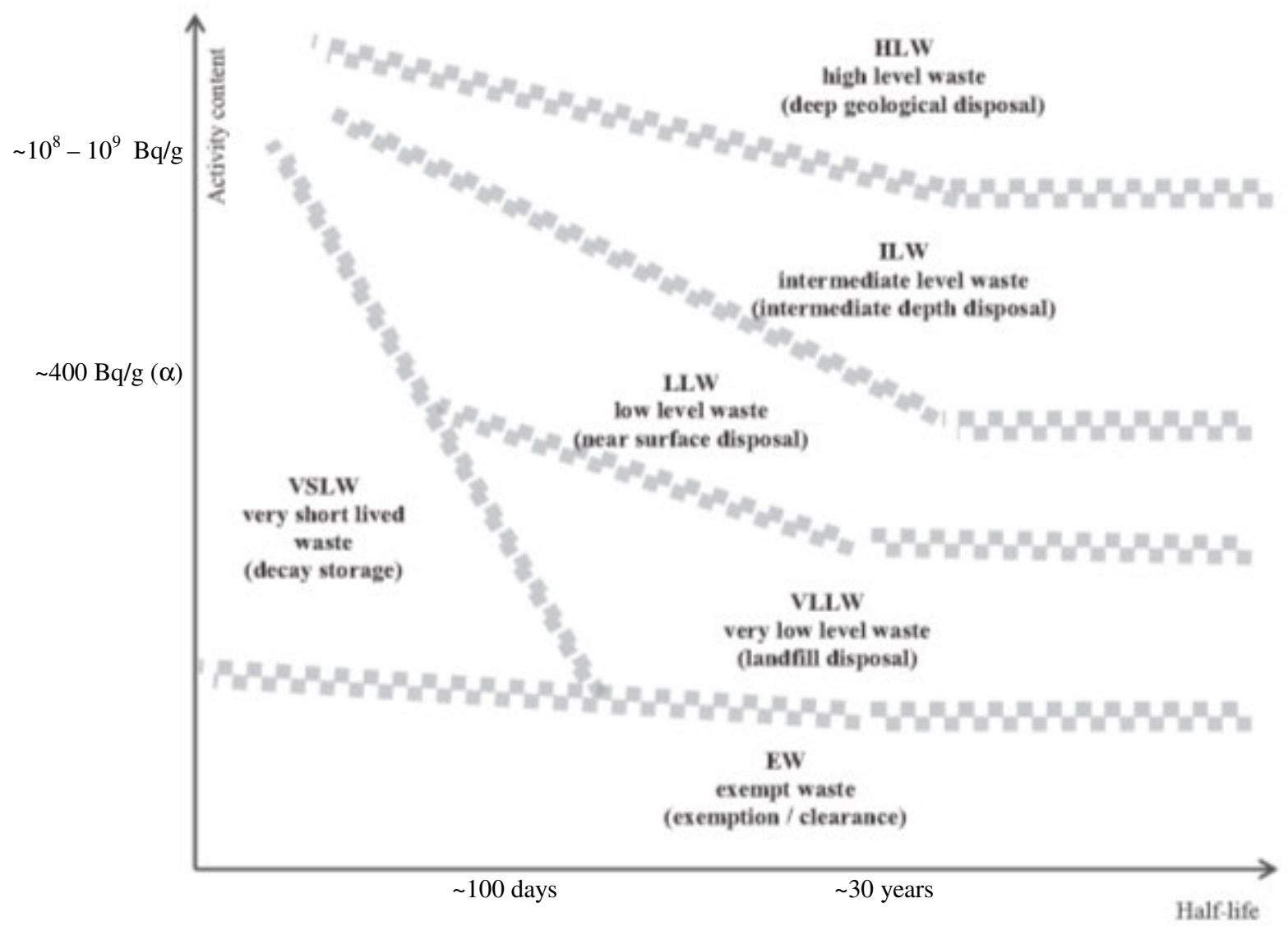

Figure 2. Conceptual Illustration of the IAEA Waste Classification Scheme (IAEA 2009b) 
Low level waste (LLW) covers a very broad range of waste. It may include short lived (SL) radionuclides at higher levels of activity concentration, as well as long lived (LL) radionuclides at relatively low levels of activity concentration, and comprises some ninety percent of the volume but only one percent of the radioactivity of all radioactive waste (WNA 2011v; IAEA 2009b). It ranges from radioactive waste with an activity content level just above that for very LLW (VLLW), that is, not requiring shielding or particularly robust containment and isolation, to waste with a level of activity concentration such that shielding and more vigorous containment and isolation are necessary (typically suitable for disposal in engineered near surface facilities) for periods up to several hundred years.

A definitive or precise boundary between LLW and intermediate level waste (ILW) cannot be specified in a general manner with respect to activity concentration levels, as limits on the acceptable levels of activity will differ between individual radionuclides or radionuclide groups. In general, ILW contains higher amounts of radioactivity, requires some shielding, a greater degree of containment and isolation than LLW, and makes up about seven percent of the waste volume with four percent of the total radioactivity (WNA 2011v). The waste acceptance criteria for a particular near surface repository, and whether they will accept LLW and/or ILW, will be dependent on the actual design of and planning for the facility (e.g. engineered barriers, duration of institutional control, site specific factors) and considerations for both short- and longterm safety-management (IAEA 2009b; CNSC 2008).

There are many licensed disposal being safely operated worldwide for low and intermediate level radioactive waste (LILW). However, in some countries facilities have been closed and are presently under active institutional control. In other countries, these types of waste are currently in interim surface or sub surface storage, to ensure the safe storage of radioactive waste pending the availability of a long-term management/disposal (WNA 2010b). For some of these countries without disposal capacities, radioactive waste is or has been generated to the extent that disposal facility construction must be considered and some have already initiated facility development.

\section{TYPES OF DISPOSAL FACILITIES}

Commonly accepted international management options for LLW include near-surface disposal at or below ground level, or placement in rock cavities below ground level (IAEA 2009b; IAEA 2007; WNA 2010b). A range of technical solutions exist for the emplacement of radioactive waste in near surface environments. The selection of a disposal option depends on many factors, both technical and administrative, such as the radioactive waste management policy; national legislative and regulatory requirements; waste origin, characteristics and inventory; climatic conditions and site characteristics; public opinion; etc. (IAEA 2007). All types of near surface disposal rely on a system of passive engineered and natural barriers to prevent, or very drastically delay, the transport of radionuclides into the environment. The specific features and characteristics of the protective barriers may differ significantly between various facilities.

Disposal facilities constructed on the surface, typically forming a mound or hill, use primarily engineered barriers to prevent water from entering into the disposed waste, thus maintaining diffusion controlled transport of radionuclides, which is an extremely slow process (Bergman 2006). An advantage of this mound-type repository design is that the waste is emplaced well above the groundwater table and the waste stays dry as long as the protective barriers are intact, which may be on the order of hundreds of years. These mound-type disposal facilities 
also have relatively moderate technical requirements for the site, so it is usually easy to find places to locate them. The main disadvantage for surface disposal is that the protective cover of the waste is exposed to weathering and erosion that can endanger the integrity of the repository (Bergman 2006). A typical example is the repositories in Centre de l'Aube in France.

Trench-type near surface repositories emplace waste in engineered trenches (also commonly referred to as vaults or pits) in the ground and can be located above or below the groundwater table. These types of disposal facilities are not as heavily impacted by weathering and erosion, as compared to the hill-type. Construction costs for trench-type facilities are usually comparative to the hill-type disposal option; however, it is generally more difficult to find technically suitable locations for this the trench style concept, since there are larger constraints on the hydrogeological parameters. Also, the fact that they are normally located closer to or in the groundwater table makes it more difficult to assess the long term safety and degradation of structures may be larger (Bergman 2006). Typical examples are the repositories at Sellafield in UK and Rokkasho-Mura in Japan.

Underground near surface and deep disposal facilities utilize caverns, rock cavities, or boreholes, with access through tunnels, and can be built in existing mines or in intentionally excavated caverns in various geological formations. In rock cavity disposal, the waste is normally placed below the ground water table and will thus have a water saturated environment outside the engineered barriers soon after closure of the repository. The location requirements for construction of an underground repository are higher than for construction on and in the surface; therefore it may not be as easy to find technically suitable sites. The construction of these types of facilities is typically more costly than corresponding construction on or in the ground. However, underground repositories have the benefit of being less visible (Bergman 2006). The repository at Forsmark in Sweden is an example of underground facilities constructed in wet crystalline rock, tens of meters below the bottom of the Baltic Sea. Investigations to make repositories in rock salt and clay are also currently done in Germany, Russia, and Belgium.

Finally, specially designed interim surface or sub surface storage waste facilities can be used to ensure the safe storage of LILW pending the availability of a long-term management/disposal option. Interim storage can be short-term or long-term, but is not a final solution. Interim storage is typically used by smaller countries that may not have the land area, favorable geology, or resources necessary to take the proper measures on their own to assure adequate safety and security, or they may not have enough radioactive waste to make construction and operation of their own repositories economically feasible. However, interim storage facilities are also currently in use in many countries, including Australia, Belgium, and Germany, with operational land-based near-surface disposal facilities (WNA 2010b).

It has been suggested that there could be multinational or regional repositories located in a willing host country that would accept waste from several countries. These facilities might include, for example, use by others of a national repository operating within a host country, or a fully international facility owned by a private company operated by a consortium of nations or an international organization. However, for the time being, many countries would not accept nuclear waste from outside their borders under their national laws (WNA 2010b). Thus, no such facility currently exists.

However, for several years, the EC has attempted to pass directives aimed at ensuring a common approach to radioactive waste management and nuclear safety. The "top-down" approach has met with considerable opposition from several Member States, and, as a result, 
has been revised on several occasions. In July 2011, the European Union (EU) finally adopted a version that requires member countries to develop national waste management plans for EC review by 2015 . The plans must include firm timetables for the construction of disposal facilities, descriptions of needed implementation activities, cost assessments, and financing schemes. The agreement also allows two or more member nations to develop joint disposal facilities and permits transport of used fuel and radioactive wastes within the EU. Exports outside the EU would only be possible to countries that already have a repository in operation that meets IAEA standards. In additional, the shipment of used fuel and radioactive wastes to African, Pacific, and Caribbean countries and to Antarctica is explicitly banned. Safety standards promulgated by the IAEA will also become legally binding within the EU-wide policy framework (WNA 2011v; EC 2010).

\section{WORLDWIDE DISPOSAL FACILITIES}

This section discusses status in individual countries regarding their nuclear capabilities, regulation and legislations, waste management practices and facilities, and current and future initiatives. The countries included were selected based on their nuclear power capabilities and involvement in the nuclear fuel cycle.

\subsection{Argentina}

\section{Nuclear Capabilities}

Argentina has two nuclear power plants (NPP) in operation, Atucha-1 and Ernbalse, generating nearly one-tenth of its electricity. They also have a third reactor in the advanced stage of construction, expected to go online on in early 2012, and two more are being planned, with the Atucha site the most likely location (WNA 2011d; ARN 2010). In addition, Argentina has five research reactors in operation (one more planned and two additional shut down or under decommissioning), complete facilities at the front end and back end of the fuel cycle, and several laboratory facilities that support numerous major research and development (R\&D) programs, including: innovative reactors, advanced fuel elements for nuclear power plants and research reactors, materials, radiochemistry, radioisotopes for medicine and industry, sent fuel management, radioactive waste management, health physics, nuclear safety, etc. (WNA 2011d; Harriague et al. 2007; Audero 2004; Jinchuk 1999; Maset and Andresik 2007).

\section{Regulation and Legislation}

The National Law of Nuclear Activity, passed in April 1997, is the legal framework for the peaceful uses of nuclear energy. This act states the National Atomic Energy Commission (Comisión Nacional de Energía Atómica, CNEA), initially set up in 1950, will perform the functions of nuclear research and development. In addition, the CNEA is the organization responsible for radioactive waste management and nuclear power plant decommissioning. Waste management is financed using a special national fund, also created by the National Law of Nuclear Activity, which is paid into by the various operating plants. All regulatory activities related and applicable to nuclear activities and radiological safety are controlled by the Argentine Nuclear Regulatory Authority (ARN), a completely independent organization that reports directly to the Argentine President (WNA 2011d; ARN 2010). 


\section{Waste Management Practices and Facilities}

With only two major power plants in operations, and no nuclear defense program, the amounts of radioactive wastes are relatively small compared to other industrialized nations. The major waste producers are the two operating NPP's that contribute approximately 50 cubic meters $\left(\mathrm{m}^{3}\right)$ per year (yr) of LLW. In addition, it has been calculated that the decommissioning of the nuclear installations within Argentina would produce approximately $60,000 \mathrm{~m}^{3}$ of radioactive waste (around 90 percent would come from the dismantling the NPP's), without conditioning or recycling. Of this decommissioning waste, 85 to 90 percent would be classified as LLW. The remainder of the nuclear activities, including research reactors, R\&D laboratories, hospitals, universities, isotope production plants, and industrial and medical application facilities, produces only about $60 \mathrm{~m}^{3} / \mathrm{yr}$ of LLW, which are negligible when compared to those arising from the NPPs operation and decommissioning (Audero 2004; Jinchuk 1999).

In general, all LLW from Argentina's nuclear activities are handled at CNEA's Ezeiza Radioactive Waste Management Area (EMA), which is part of the Ezeiza Atomic Center (EAC), located in the Province of Buenos Aires. The EMA covers an area of nearly 20 acres (8 hectares [ha]) and has been in operation since the early 1970's (Rep Arg 2008; Maset and Andresik 2007; IAEA 2011a). Figure 3 provides an overview of the various facilities located in the EMA site, which are described in further detail below. Beginning in 1995, only conditioned LLW requiring isolation periods of up to 50 years are subjected to final disposal at the EMA, with wastes disposed of before 1995 considered historic. Thus, the EMA also has temporary storage for wastes that, based on their characteristics, type of radionuclides, and activity concentration cannot be disposed of in the EMA and are waiting for the construction of an appropriate repository (Maset and Andresik 2007). The LLW disposal facility at the EMA has a

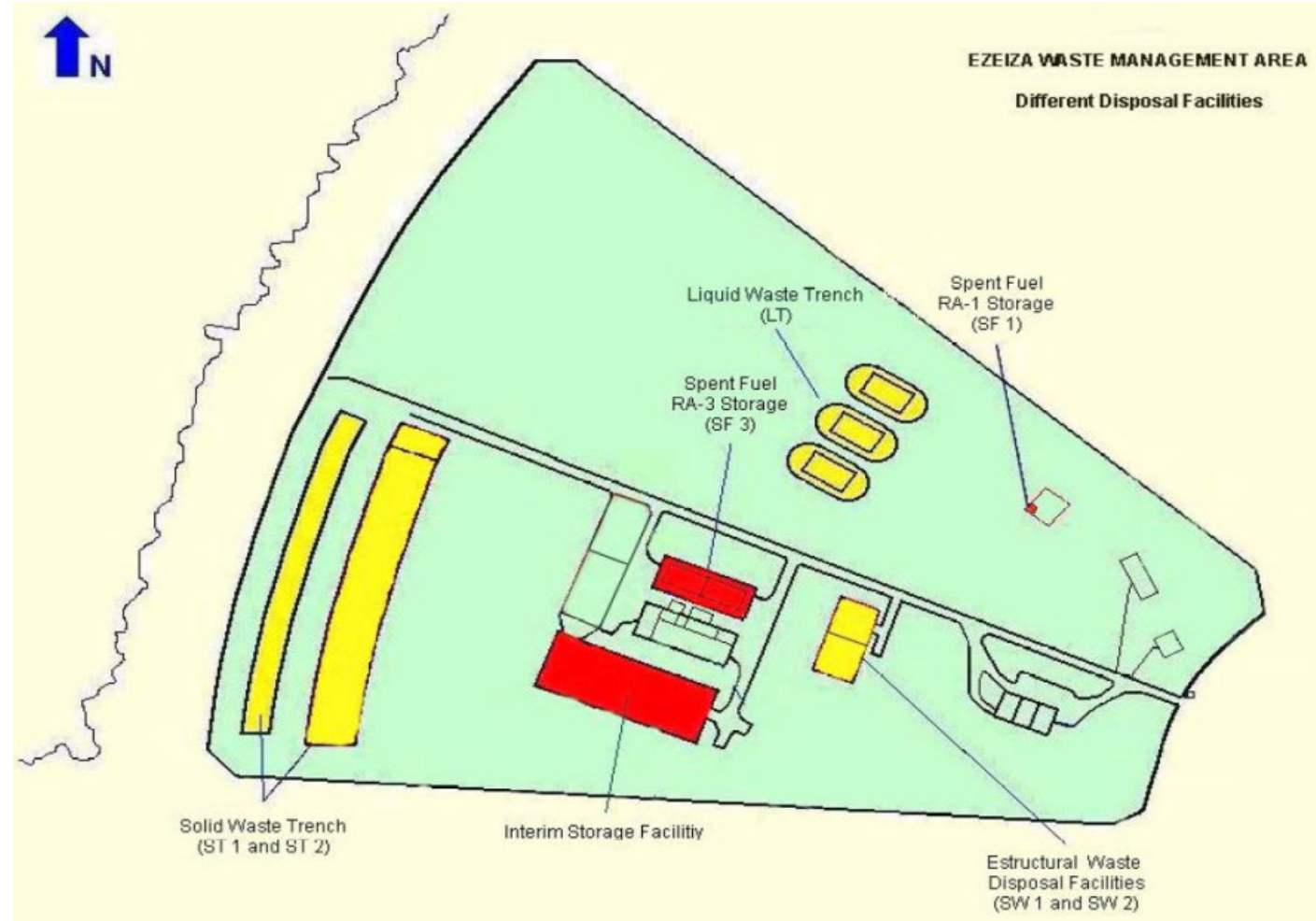

Figure 3. Disposal facilities located at the EMA (Maset and Andresik 2007) 


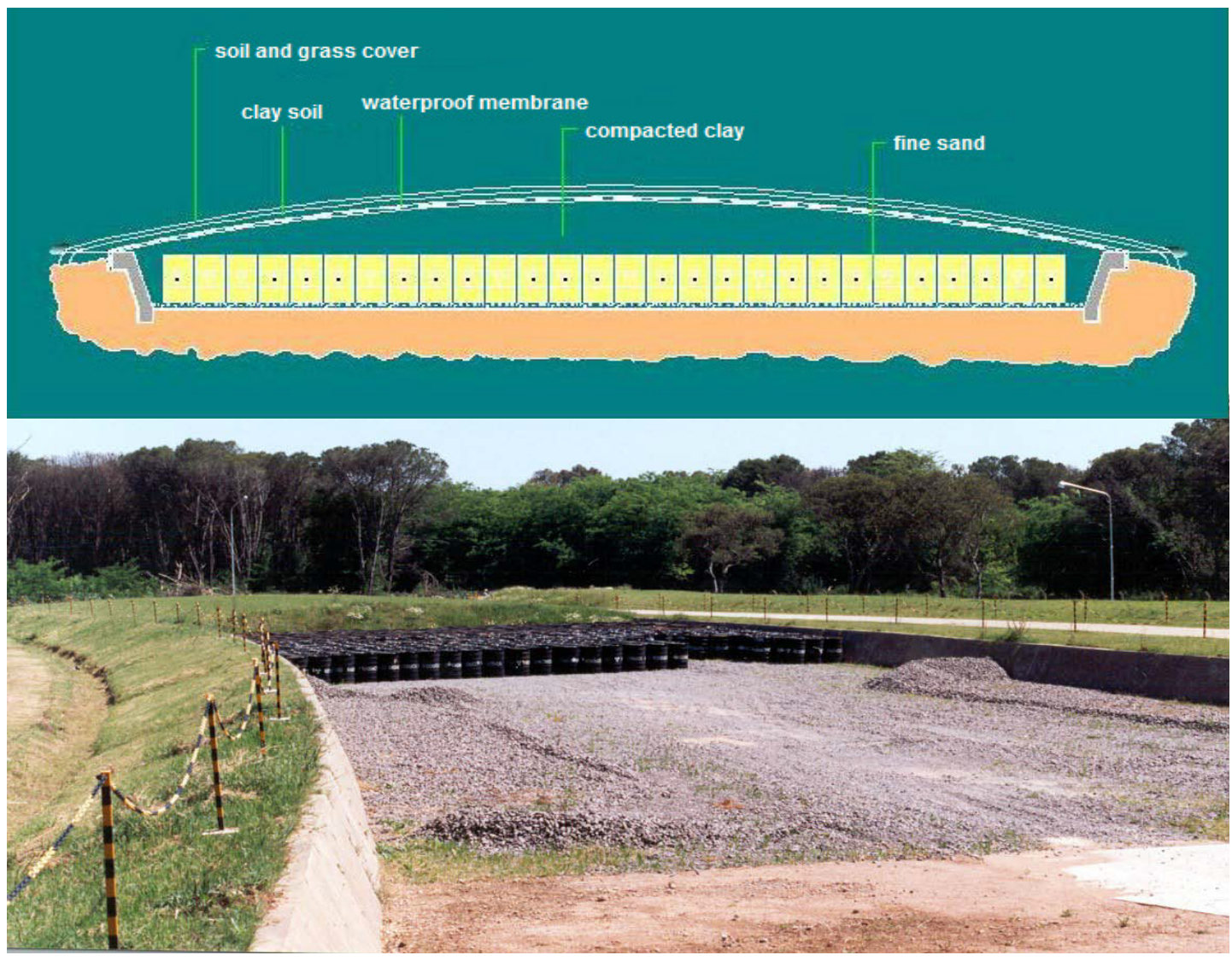

Figure 4. Diagram and picture of trench type used for the disposal of solid LLW at the EMA (Grattone 2010)

sorting area, incineration furnace, compactor, decontamination facility, and equipment for immobilization and cementation of solid and liquid wastes (Jinchuk 1999; IAEA 2011a). Following treatment, solid LLW is packaged into 200 liter (L) drums and disposed of in nearsurface engineered trenches. There are two solid waste trenches at the Ezeiza facility. The first trench $\left(700 \mathrm{~m}^{3}\right.$ capacity) opened in 1975 . It was built in natural soil without any type of engineered improvement and was subsequently closed in 1988 with some historic waste in it (IAEA 2011a). The second trench (1120 $\mathrm{m}^{3}$ capacity) started operation in 1989, and is illustrated in Figure 4. It was built in compacted calcareous-silty soil, supporting a leveled broken stone bed with slopes toward both sides, 30 centimeter $(\mathrm{cm})$ thick concrete perimeter retaining walls, and a rain water drainage system that would prevent water accumulation around drum is filled with sand and bentonite, and successive layers of compacted soil, asphalt, sand, polyethylene film, loose soil, and grass are placed on the top of the drums (Jinchuk 1999).

The solid LLW from the NPPs is treated, conditioned, compacted or immobilization in cement, and packaged into drums in-situ in special facilities built at each of the two sites (Jinchuk 1999; IAEA 2011a; IAEA 2004). The $200 \mathrm{~L}$ drums produced at Atucha-1 were sent to the Ezeiza facility for disposal (prior to 2001), and are currently being stored on a temporary unit on-site. The LLW waste drums produced in Embalse are installed for interim dry storage in a special building located in the same site, due to a province regulation forbidding transportation of any radioactive waste through this province (IAEA 2004).

The Ezeiza Atomic Centre also has concrete pits, which are considered an alternative waste management option for low-impact solid waste that according to its activity or geometry cannot 
be disposed of in the existing trenches. Wastes disposed of in this system are usually metal parts from contaminated areas. The system comprises two underground pits $\left(240 \mathrm{~m}^{3}\right.$ total capacity) that are $4 \mathrm{~m}$ diameter and $10 \mathrm{~m}$ deep, with $30 \mathrm{~cm}$ thick reinforced concrete side walls and bottom. Periodically, concrete is poured inside the pits in order to immobilize the contaminated materials and reduce the dose rate at the top. The first pit was commissioned in 1972 and was operated until 1995 without an Operating License and therefore the wastes in it are considered historic. The second pit was in operation from 1999 to 2001, when the safety reassessment was commenced. In addition, there are another two previous and smaller pits with historic wastes (IAEA 2011a).

ILW consists primarily of activated or contaminated parts arising from maintenance and repairs at the operating NPPs, research reactors, and radioisotope facilities. Due to the small volume produced up to date, ILW is under interim storage either at the NPPs (resins placed in tanks, large parts in the spent fuel elements pool), or in drums placed in concrete containers stored in a special building at the Ezeiza Atomic Centre (Audero 2004).

\section{Current and Future Initiatives}

Following the initiation safety re-assessment and subsequent shutdown of all radioactive waste disposal system at EMA in 2001, a characterization of the EMA site and surrounding areas were started in order to reassess the area safety, maintain an appropriate radiological and environmental surveillance, and decide future actions (Maset and Andresik 2007). In 2006, the CNEA decided to permanently suspend operation of the final disposal systems at the EMA, independent of the results from the safety reevaluation, since these systems had already concluded their operative stage of approximately 30 years (Rep Arg 2008; Maset and Andresik 2007). Post 2001, the LLW wastes temporarily stored at interim facilities at the NPPs, are awaiting a decision on their final management or the construction of an appropriate new LLW repository (Rep Arg 2008; ARN 2010).

The amount of ILW that has and will be generated, especially from the dismantling and decommissioning of the nuclear facilities, indicates the need for a permanent ILW repository for final disposal. This ILW repository would likely be of a near-surface monolithic concrete or subsurface geologic type (Audero 2004). Since Argentina already requires a location for the siting of a new LLW repository, it plans to build both final disposal facilities at the same, yet to be determined, site (Maset and Andresik 2007).

\subsection{Armenia}

\section{Nuclear Capabilities}

The Republic of Armenia has relied heavily on nuclear power since 1976. It currently has one NPP in operation (at Metsamor), which supplies approximately $40 \%$ of the total electricity produced, and plans to build another by 2018 (WNA 2010a).

The present Metsamor NPP is a safety concern to the European Union (EU) and to neighboring Turkey, $16 \mathrm{~km}$ away. A powerful earthquake in late 1998, which did not damage the facility itself, lead to a precautionary shut down of the two operating reactors due to concerns related to seismic vulnerability. Unit 1, after 13 years operation, is being decommissioned. Unit 2, which restarted in 1995 due to the severe economic crisis and lack in national energy resources, has 
undergone safety improvements with the assistance of the IAEA, but is currently scheduled to close before the end of its design lifetime (in 2016, or later), provided that alternative replacement capacity is available (WNA 2010a; IAEA 2006b).

\section{Waste Management Practices and Facilities}

There is currently no waste disposal facility in Armenia to deal with the large amounts of LLW generated from nuclear activities and the decommissioning of nuclear facilities; however, the Government adopted a decision to collect all kinds of wastes, both radioactive and chemical, in one place (Zarafyan 2010). All the LLW generated historically (total volume around $5,000 \mathrm{~m}^{3}$ ) and at present (Unit 2 produces about $310 \mathrm{~m}^{3} / \mathrm{yr}$, according to design specifications) from the Metsamor NPP is being stored at the plant site. The LLW storage facility consists of two compartments, each measuring approximately 27 by 36 by $9 \mathrm{~m}$, with total storage volume around $17,000 \mathrm{~m}^{3}$ (IAEA 2006b). Although capacity of the radioactive waste storage facilities is sufficient for the operational lifetime of the current NPP, government officials are currently discussing the construction of a burial site for radioactive wastes from the proposed NPP. The parameters proposed for the new waste burial site, exceed all the existing waste burial sites in Armenia by many times, covering nearly 100 acres (400 ha) with a one (or two) km long tunnel dug underground through the mountains to a storage bunker at least $150 \mathrm{~m}$ deep. Presently, this facility is to be constructed in the Ararat Region, but details have yet to be finalized (EcoLur 2011)

\subsection{Australia}

\section{Nuclear Capabilities}

Australia does not have an active nuclear power program, although it has some of the world's largest uranium deposits and actively mines and exports uranium for nuclear fuel. However, since 1958, three separate nuclear research reactors have been built and operated, only one of which is currently in service (NTI 2011a). As a result, compared to countries that have national nuclear power programs, the amount of waste in Australia is relatively small. In general, radioactive waste in Australia is generated from two main sources: mining activities and radionuclide use in research, industry, medical applications, and radiopharmaceutical production (OECD-NEA 2009a; FNCA 2007).

\section{Regulation and Legislation}

In Australia, radioactive waste generators are responsible for the waste they produce. Australia's regulation of radioactive waste management and disposal comes under both State/Territory and Commonwealth (federal) regulation. The Commonwealth Government is responsible for managing radioactive material from organizations under its control (including government Departments and Agencies). Commonwealth organizations are regulated by the Australian Radiation Protection and Nuclear Safety Agency (ARPANSA), while the Federal Department of Resources Energy and Tourism (DRET) is the governmental agency responsible for radioactive waste management. The States and Territories are similarly responsible for monitoring the use, transport, and disposal of radioactive materials under their control or the control of private companies or individuals in accordance with State and Territory acts and regulations, which are administered by State or Territory radiation safety authorities (OECDNEA 2009a; FNCA 2007). 
Australia recently developed a nationally endorsed radioactive waste classification system. This scheme is based primarily on the IAEA classification, including considerations of long term safety and disposal of the waste, but is adapted for the Australian situation (ARPANSA 2010). The radioactive material found in Australia is comprised largely of short-lived LILW (with very small amounts of long-lived ILW) arising from industrial, medical, and research practices and includes abandoned sources and contaminated soils (CoA 2008; DRET 2009).

\section{Waste Management Practices and Facilities}

Australia does not have a permanent national repository for LILW. The current general practice in Australia is to primarily hold radioactive waste for an indefinite period in interim storage at over one hundred locations around the country in both rural areas and urban centers.

Radioactive waste management facilities in Australia range from purpose built decontamination facilities and radioactive waste stores (illustrated in Figure 5), to temporary storage facilities where radioactive material is held in transit. None of these solutions are considered suitable for long-term strategies (OECD-NEA 2009a; WNA 2007; FNCA 2007).

According to estimations, around $95 \%$ of the stored Australian LILW inventory (approximately $4,000 \mathrm{~m}^{3}$ total) was generated by and is in storage at, Commonwealth Government institutions throughout Australia (DRET 2011a). The largest single stockpile is located at the Lucas Heights Research Laboratories of the Australian Nuclear Science and Technology Organization (ANSTO), on the south-western outskirts of Sydney. The remainder of the waste is split between by various State and Territory Government stores, Australian Defense Establishments, and private companies. The annual increase in combined LILW requiring storage is estimated approximately 30 to $40 \mathrm{~m}^{3}$, plus the future decommissioning wastes from Australia's three

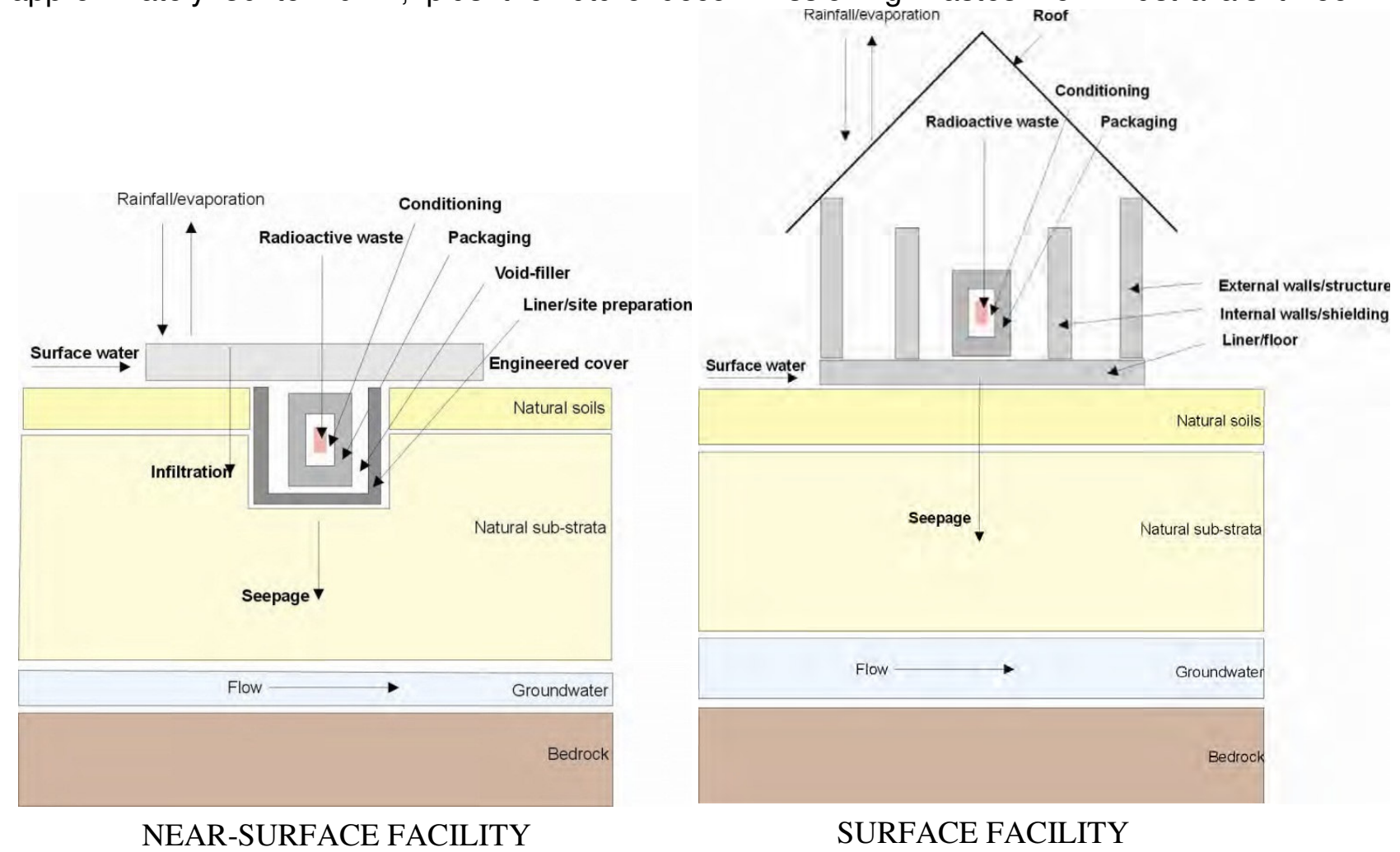

Figure 5. Illustrative design approaches for Austrailian LILW disposal facilities (DRET 2009) 
research reactor totaling about $300 \mathrm{~m}^{3}$ of LLW and $380 \mathrm{~m}^{3}$ of ILW (WNA 2007; DRET 2011a).

It should also be noted that some near surface disposal facilities already exist in Australia; however access to these repositories is limited. For example, the Mount (Mt) Walton East Intractable Waste Disposal Facility (IWDF), located approximately $480 \mathrm{~km}$ northeast of Perth, accepts waste originating from within Western Australia only. The IWDF opened in 1988 and currently is owned and operated by Waste Management (WA) on behalf of the Western Australian Government, with senior officers in the Australian Environmental Protection Authority (EPA), working for WA, managing the site (DTF 2011; Hartley 1998; EPA 2000). This site occupies nearly 25,000 acres ( $2500 \mathrm{ha}$ ) includes a near surface repository for LLW, along with disposal options for chemical, and other intractable wastes and is only used when all other practicably available disposal, recycling, and re-use options have been exhausted (EPA 2000). The LLW waste disposed of at Mt Walton East is packaged in $60 \mathrm{~L}$ drums and placed inside $200 \mathrm{~L}$ drums that are filled with a cement mix. The $200 \mathrm{~L}$ drums are disposed of by placing them in a $2 \mathrm{~m}$ diameter by $28 \mathrm{~m}$ deep shaft with three drums per layer, as illustrated in Figure 6. The tops of the shafts were prepared with concrete collars. A concrete base was laid at the bottom of each shaft. Drums are progressively concreted into place and the shaft is eventually covered with $8 \mathrm{~m}$ of natural fill and capped with a $0.15 \mathrm{~m}$ layer of concrete (Hartley 1998). Alternately, LLW disposal may be carried out using the trench burial technique (EPA 2000).

\section{Current and Future Initiatives}

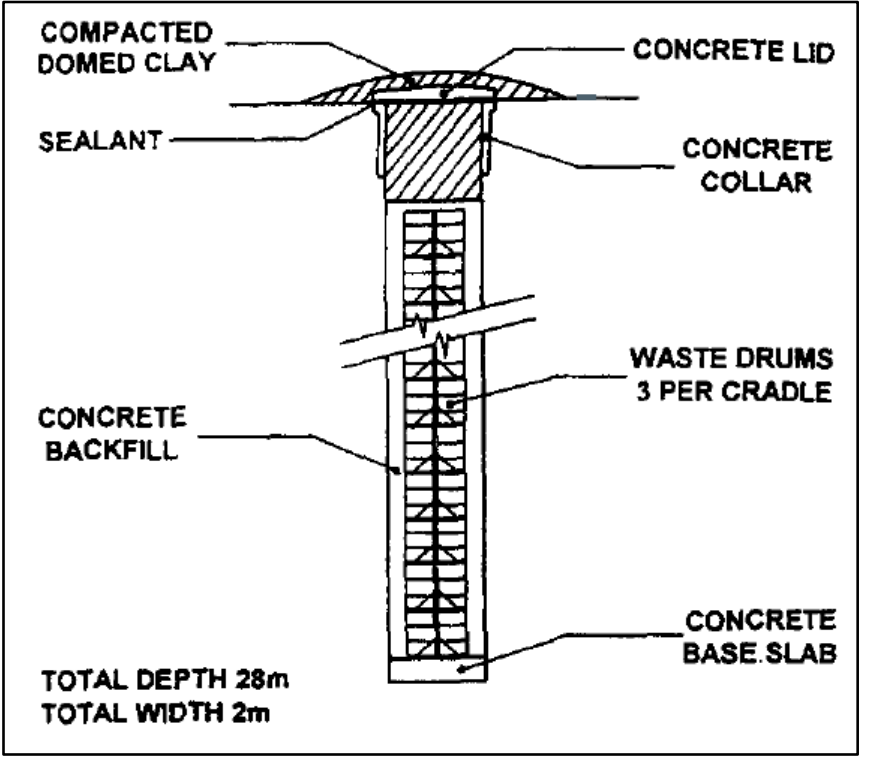

Figure 6. Diagram of Disposal Shaft at Mt Walton East IWDF (Hartley 1998)

The increasing volumes of material in storage facilities, and general community concern, highlight the need for the establishment of national and/or state repositories. The Australian government is committed to the development and implementation of an integrated long-term waste management strategy to safely dispose of radioactive wastes arising from its nation's activities and minimize the burden on future generations (CoA 2008; FNCA 2007). In line with this strategy, Australia is in the process of selecting a site for a Commonwealth Radioactive Waste Management Facility (CRWMF), which likely involve a near surface repository design.

Since the late 1970s, there has been an evolving process of site selection for a national radioactive waste repository for LLW and short-lived ILW (WNA 2007). In May 2003, a final site for the national repository near Woomera in South Australia was decided; however, in mid-2004, bowing to state-level political implications, the Australian government abandoned these plans and instructed the states each to set up their own, to international standards. In 2005, with the passing of the Commonwealth Radioactive Waste Management Act, the Australian Government announced that a new CRWMF, for management of radioactive waste of Commonwealth origin only, would be located in the Northern Territory. Selection was to be based on a field assessment, followed by environmental assessment, and licensing. During 2006-08, site investigations at four locations in the Northern Territory, including three on land managed by the 
Department of Defense, were undertaken as potential sites for a low-level waste repository and community consultations occurred (OECD-NEA 2009a; CoA 2008; WNA 2007; FNCA 2007).

In 2010, new legislation, entitled the National Radioactive Waste Management Bill, was introduced to repeal the Commonwealth Radioactive Waste Management Act of 2005. The new act will establish a facility to manage radioactive waste generated by Australia's medical, industrial, agricultural, and research use of nuclear material and will ensure that the selected site undergoes full environmental, heritage, and other approval processes. In addition, this new bill requires any site to be volunteered by landowners; thus, the previously selected three sites have since been ruled out and there will be no pre-determined site selection process (DRET 2011b). In addition, Australia does not currently have a repository for its long-lived ILW and thus requires such a purpose-built store. As a result, the Commonwealth has decided to investigate sites at which both types of facility can be accommodated (DRET 2009).

Criterion for siting a repository is identified within the Code of Practice for the near-surface disposal of radioactive waste in Australia that was first developed in 1992 by the National Health and Medical Research Council (NHMRC) and is now administered by the ARPANSA. This code, which also establishes facility design and operational requirements, includes as part of the site selection process consideration of the hydrology, geology, seismology, geochemistry, meteorology, ecology, and demography of a site and surrounding area (NHMRC 1992; DRET 2009). Once a preferred site is selected, a 2-year environmental assessment process will begin, in conjunction with the site licensing process. It is expected that the LLW and short-lived ILW will be contained in drums or concrete and disposed of in a shallow, engineered trenches with a secure multi-layer cover at least $5 \mathrm{~m}$ thick, to ensure that radioactive material is contained and allowed to decay safely to background levels (WNA 2007). The facility for conditioned longlived ILW is planned as an engineered, above-ground building (DRET 2009). The Australian Government, represented by the DRET will own the CRWMF, but it is expected that a contractor will manage the facility on a day-to-day basis (OECD-NEA 2009a).

\subsection{Belgium}

\section{Nuclear Capabilities}

Belgium has seven nuclear power reactors that supply between 50 to 60 percent of the country's domestically-generated electricity. The Belgian Nuclear Research Centre (Studiecentrum voor Kernenergie, or SCK/CEN) also operates one large research reactor along with two smaller units, and is planning construction of a fourth unit in 2015 (WNA 2011e; OECDNEA 2010a).

\section{Regulation and Legislation}

The Belgian Agency for Management of Radioactive Waste and Enriched Fissile Materials (Organisme national des déchets radioactifs et des matières fissiles/Nationale instelling voor radioactief afval en splijtstoffen, or ONDRAF/NIRAS) is the national agency responsible for the development and implementation of a coherent and safe waste management policy for all radioactive materials located on Belgian territory. The ONDRAF/NIRAS was established by Belgian authorities in 1980 in order to entrust the management of radioactive waste to one single institution under public control and ensure that the public interest would play a crucial part in all decisions on the subject. Management activities include the transport, treatment, 
processing, conditioning, interim storage, and disposal of radioactive waste, along with some aspects of decommissioning (at the request of the nuclear facility operator). The ONDRAF/NIRAS is also in charge of establishment and maintenance of a qualitative and quantitative inventory of radioactive waste and the country's nuclear liabilities (i.e., all facilities and sites containing radioactive substances) on Belgian territory. This inventory deals with not only the amounts and physico-chemical and radiological characteristics of existing waste, but also any future operational and decommissioning waste, be it conditioned or non-conditioned, expected to arise until the end of the Belgian nuclear program (Belgium 2006; Cosemans 2004).

In Belgium, radioactive waste is classified according to characteristic radiological and chemical similarities, using a system that is somewhat compatible with the IAEA international classification and can, if necessary, be adapted to take account of changes that may occur in the waste management (Belgium 2006). For conditioned waste, the ONDRAF/NIRAS classifies waste into three categories. Category A includes short-lived LILW, which is defined as containing small amounts of mainly beta and gamma emitting radionuclides with half-lives of less than 30 years, with minute quantities of long-lived alpha emitters (i.e., maximum of between 400 to $4,000 \mathrm{~Bq} / \mathrm{g}$ activity). Category A waste is considered suitable for surface disposal. Category B, or long-lived LILW, includes waste containing primarily alpha emitters with half-lives exceeding 30 years, with intermediate amounts of amounts of beta and gamma emitters. In general, waste included in category $B$ is that which does not meet the radiological criterion for belonging to category $\mathrm{A}$, but does not generate enough heat to belong to category $\mathrm{C}$. Category $\mathrm{C}$ includes long-lived HLW, which contains substantial quantities of alpha, beta, and gamma emitters of various life spans together and generates considerable amounts of thermal power (i.e., more than $20 \mathrm{~W} / \mathrm{m}^{3}$ ). Waste from categories $B$ and $C$ is to be disposed of such a manner that it is permanently isolated from the biosphere, for example, via deep geological disposal (ONDRAF/NIRAS 2011; OECD-NEA 2010a; Belgium 2006).

\section{Waste Management Practices and Facilities}

In Belgium, about 70 to 80 percent of the radioactive waste produced arises from the nuclear power industry, with the remaining 20 to 30 percent generated by nuclear research, production of radioisotopes, use of radioisotopes in medicine, industry, and private laboratories, and the Euratom Institute for Reference Materials and Measurements (IRMM). According to 2009 estimations, the total volume of conditioned waste to be managed through 2070 is approximately $70,000 \mathrm{~m}^{3}$ for category $A$ and between about 9,000 and $11,000 \mathrm{~m}^{3}$ for category $B$ (OECD-NEA 2010a; ONDRAF/NIRAS 2011).

ONDRAF/NIRAS started working on the long term management of short lived LLW shortly after its creation in 1980. Sea disposal of conditioned LLW, which had been practiced on a regular basis in Belgium until the early eighties, had become very uncertain as of 1984, when Belgium decided to adhere to the international moratorium of 1983 between the signatory countries of the London Convention on sea pollution (Hooft and Boyazis 2007). One of the agency's first actions after sea disposal had been suspended, was the development and implementation of a methodology for waste processing and conditioning, to ensure the stabilization of short-lived LLW, and the construction of interim storage buildings. As of the end of 2009, there were two storage buildings in operation for LLW (housing more than $14,500 \mathrm{~m}^{3}$ of conditioned waste, with total combined capacity of around $16,600 \mathrm{~m}^{3}$ ) and three for ILW (storing approximately $4,700 \mathrm{~m}^{3}$ of conditioned waste) (OECD-NEA 2010a). 


\section{Current and Future Initiatives}

Once the short-term management of the waste had been ensured, ONDRAF/NIRAS concentrated its efforts on the development of solutions for long term waste management. In June 2006, after years of studies and coordination with local authorities, the government decided to situate the primary waste treatment, conditioning, and storage facility at Dessel. The Dessel site, located in the Campine area of Belgium about $60 \mathrm{~km}$ east of Antwerp, covers an area of nearly 6,700 acres (about 2,700 ha) (Derveaux and Waffeleart 2004). Since the 1950s, nuclear related facilities and businesses have established their headquarters in the surrounding district creating a nuclear zone that extends over the municipalities of Dessel, Mol, and Geel. In addition to the various industrial companies, this zone contains two nuclear research institutes, the Studiecentrum voor Kernenergie (SCK-CEN) in Mol and Instituut voor Referentie Materialen en Metingen (IRMM) in Geel (STOLA 2004). The Dessel project is currently in its detailed studies phase, which covers the period 2007 to 2011, during which all the components of the project are elaborated and decided on in preparation for the implementation and realization phase, which is planned to begin in 2012. Full operation of the surface disposal facility is expected by the year 2016 (OECD-NEA 2010a).

The Dessel LLW disposal facility will be run by Belgoprocess, an international private company and industrial subsidiary of ONDRAF/NIRAS that offers integrated nuclear waste management and decommissioning services and has its home base in Dessel (and Mol) (Belgoprocess 2009). The Studie- en Overleggroep Radioactief Afval Dessel (STORA, or Dessel Study and Consultation Group on Radioactive Waste), an independent non-profit association composed of organizations and residents of the Belgian municipality of Dessel, is responsible for the monitoring of all nuclear affairs in Dessel, including the various kinds of radioactive waste that are being transported, processed, stored and which possibly in the future will be disposed of there. STORA keeps the population of Dessel informed about all these affairs, watches out for their interests, and formulates advice with a view to municipal policy (STORA 2011). The costs associated with managing the facility are passed on to the producers of radioactive waste, notably the power companies. Utilities pay a levy on each kilowatt-hour (kWh) of electricity sold, which goes into a decommissioning and waste management fund (WNA 2011e; Van Zaelen and Cosemans 2005).

The Dessel facility will act as waste generator (conditioning waste as a subcontractor of ONDRAF/NIRAS) and waste receiver (storage facilities). Several techniques are used to optimize the overall concept of waste conditioning and treatment, including incineration, pre-compaction, super compaction, and mechanical and thermal size reduction techniques (Van Zaelen and Cosemans 2005). The surface disposal facility was designed in a progressive, flexible, and reversible manner. Category A waste, which may or may not be first packed in $400 \mathrm{~L}$ steel drums, is disposed of in concrete casings (measuring 2 by 2 by 1.3 $\mathrm{m})$ that are filled up with cement mortar. These monolithic blocks, illustrated in Figure 7, are then placed in one of 40 large above ground concrete modules, arranged in two by two rows of 10 modules, that can hold nearly 940 monoliths each piled in six layers. The Dessel surface

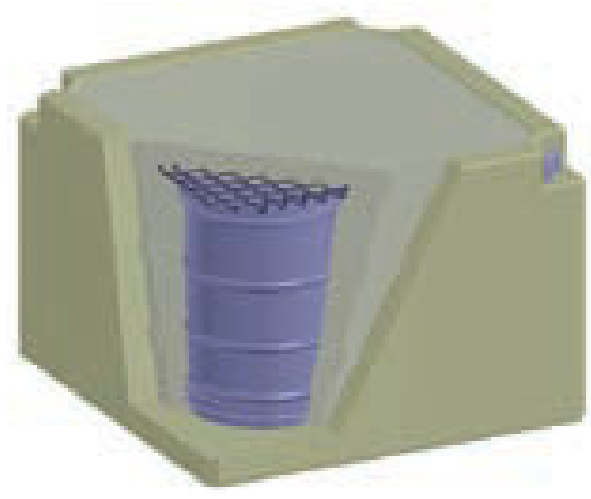

Figure 7. Cross-section of concrete monolithic blocks at Dessel facility (ONDRAF/NIRAS 2007) disposal facility is illustrated in Figure 8. During construction and placement, the disposal modules are temporarily covered by fixed steel roofs. When the module ready for permanent 


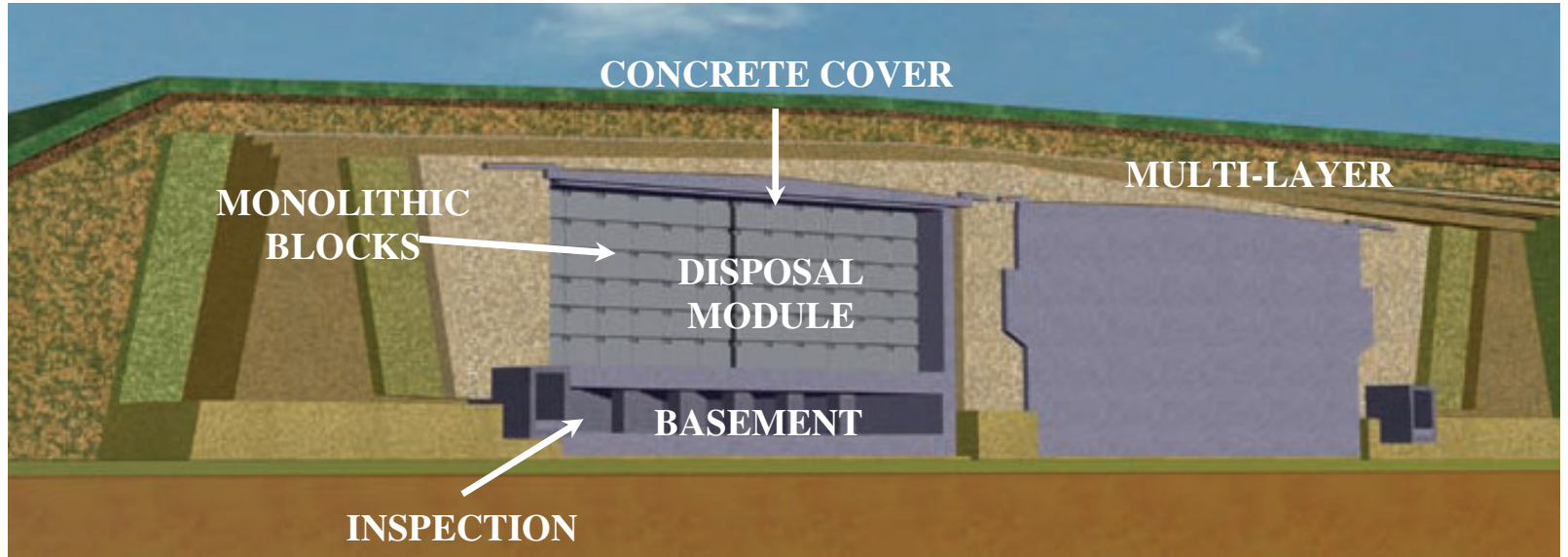

\section{Figure 8. Dessel surface disposal facility (STOLA 2004)}

closure, all remaining space will be backfilled with sand and the steel roof replaced with a concrete cover plate and definitive multi-layer impermeable protective covering consisting of a variety of natural and synthetic materials. After final covering, the disposal site will look like two hills $20 \mathrm{~m}$ high and together approximately 160 by $950 \mathrm{~m}$, as illustrated in Figure 99 . The floor of the disposal modules is supported by $2 \mathrm{~m}$ high pillars that create basements under the modules, which are accessible from the inspection galleries, such that the lower part of the modules can be checked for cracks or leaks. A network of pipes collects any water that might seep into the disposal installation and sampling pipes are positioned around the disposal site for groundwater monitoring (Derveaux and Waffeleart 2004; ONDRAF/NIRAS 2006; ONDRAF/NIRAS 2007).

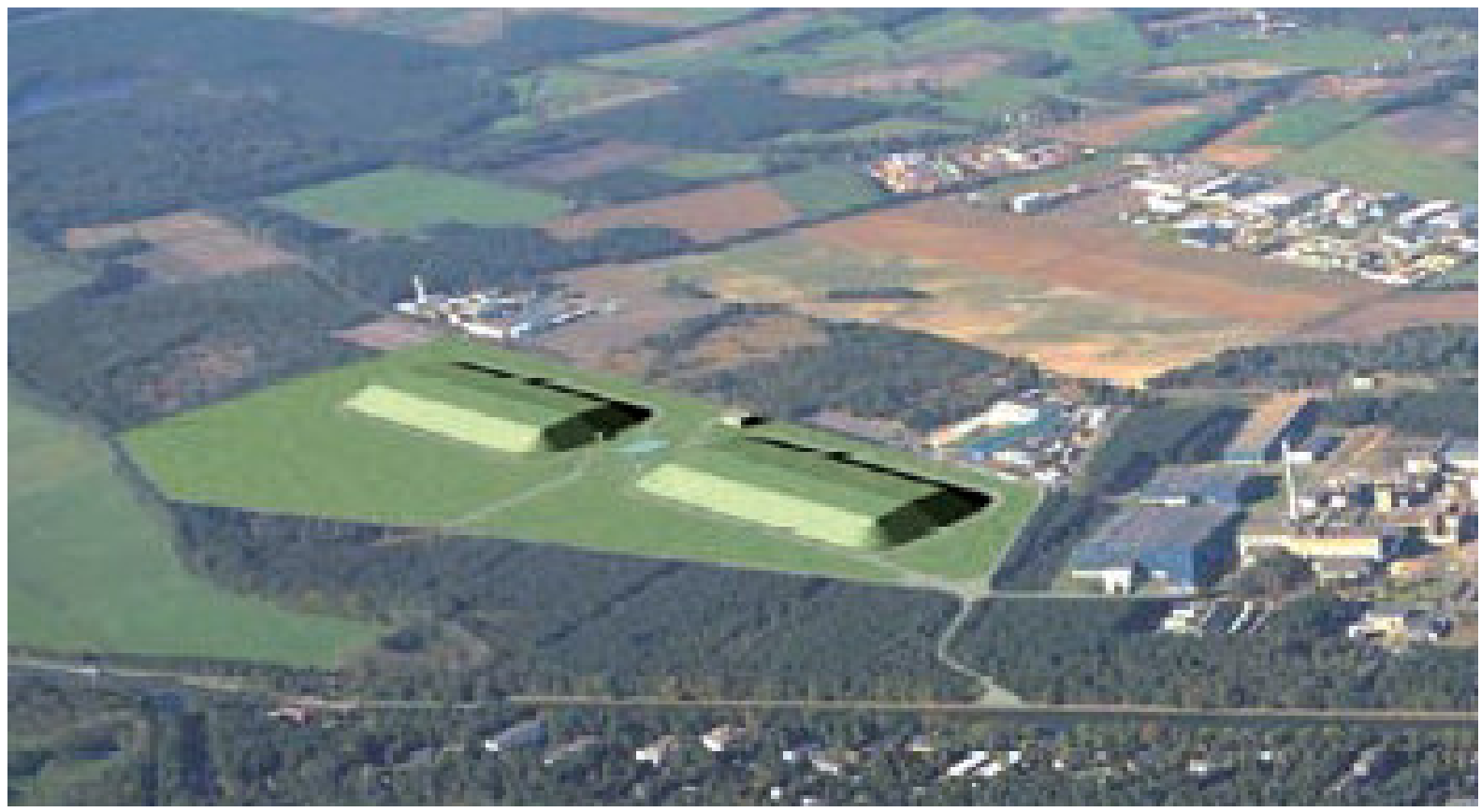

Figure 9. Illustration of the Dessel LLW surface disposal facility after permanent closure (ONDRAF/NIRAS 2007) 


\subsection{Brazil}

\section{Nuclear Capabilities}

Brazil has two NPPs, Angra 1 and Angra 2, located near the city of Angra dos Reis, about 130 $\mathrm{km}$ from Rio de Janeiro, which provide only about 3\% of Brazil's electricity. Brazil also has four operating research reactors, a third NPP currently under construction, and four additional NPPs in the planning stages (WNA 2011f; IAEA 2006a). Radioactive material is also generated due to the application of isotopes in the medicine, industry, agriculture and research, and occasionally as a result of the decontamination process following radiological incidents (IAEA 2011a; FRB 2008).

\section{Regulation and Legislation}

The Brazilian National Commission for Nuclear Energy (CNEN), which reports to the Ministry of Science and Technology (MCT), is the governmental body responsible for regulation, receipt, and final disposal of the radioactive waste from the whole country (IAEA 2011a; Fleming and Mourão 2007). Brazil currently follows the waste classification system developed by the IAEA, and with respect to waste management, short lived LIWL are grouped together.

\section{Waste Management Practices and Facilities}

The primary producers of radioactive waste are Brazil's two NPPs that are equipped with on-site systems for treatment, conditioning, and storage for all the radioactive waste they produce. Compressed solid LILW are typically conditioned in $200 \mathrm{~L}$ drums and non-compressed wastes placed in special 1,000 L boxes. For the time being, the solid LILW waste is stored in interim storage at the Angra site (pictured in Figure 8), to be later removed to a final repository. As of 2008, the total volume of LILW in interim storage in Brazil was about 3,100 $\mathrm{m}^{3}$ (IAEA 2011a).

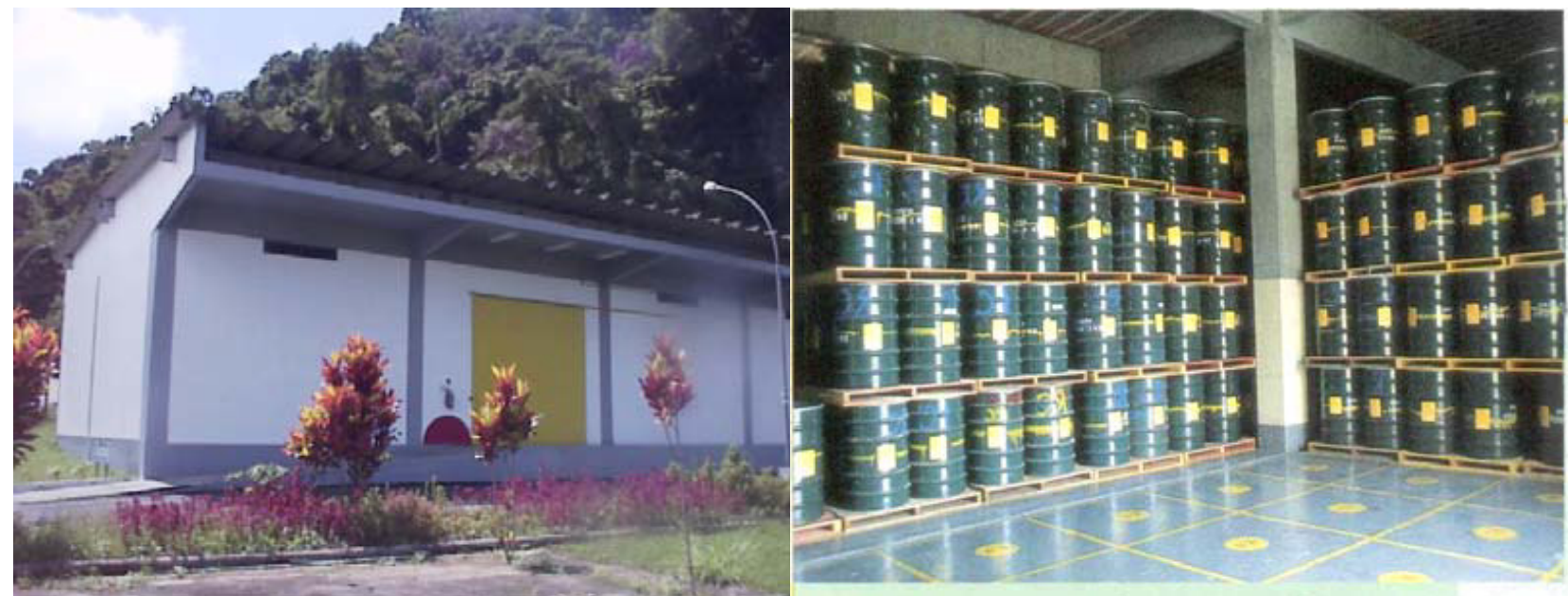

Figure 8. Angra 1, 2 radioactive waste interim storage facilities (FRB 2008)

The on-site storage at Angra 1 currently consists of three units (Storage Facility 1, 2, and 3). Storage Facility 1 entered operation in 1981, with a design capacity for about $490 \mathrm{~m}^{3}$ (nearly 2,450 drums: 500 of low level; 950 of medium level activity). As of early 2008, this facility was operating beyond its capacity, utilizing the inspection and backup areas originally destined to 
store damaged drums to increase the primary storage space (FRB 2008). Storage Facility 2 has two modules, with $2 \mathrm{~A}$ operational and $2 \mathrm{~B}$ under licensing and commissioning. Storage Facility 2A was built 1992 with the capacity to store $621 \mathrm{~m}^{3}$ (FRB 2008). According to data from March of 2008, the total amount of LILW in storage at the Angra 1 NPP was more than $1860 \mathrm{~m}^{3}$ combined. When Storage Facility 3 was authorized for operation, the waste containers were redistributed among the three interim storage buildings (FRB 2008; FRB 2010).

At the Angra 2 NPP, all the produced waste is stored in a compartment inside the plant. This inplant storage facility has a total capacity of about $330 \mathrm{~m}^{3}$ (or 1640 drums) and held just over 40 $\mathrm{m}^{3}$ (or 200 drums) as of March 2008. Additional quantities of radioactive wastes are also being temporarily stored at various CNEN research institutes throughout the country (FRB 2008). Due to the increase in the applications of the nuclear energy and radionuclide applications, the growth rate of radioactive waste in Brazil is estimated to be $50 \%$ every ten years, and consequently, the capacity available for this interim storage system will diminish quickly (Fleming and Mourão 2007).

In 1995, a near surface disposal facility was constructed in Abadia de Goiás, a small town about $23 \mathrm{~km}$ from Goiânia, following the 1987 accident with a disused ${ }^{137} \mathrm{Cs}$ source that resulted in the contamination of a significant part of the city of Goiânia. According to the IAEA classification, all the radioactive waste collected in Goiânia falls into the category of low-level short lived, which allows for disposal at shallow depths, in engineered storage facilities. There was approximately $3,500 \mathrm{~m}^{3}$ of radioactive waste packaged in drums and metal boxes, which was temporarily stored on open-air concrete platforms (pictured in Figure 9) while they awaited final disposal. The disposal facility includes two near-surface repositories. One repository, called Great Capacity Container, was designed to handle disposal of lowest activity waste (average concentration $27 \mathrm{~Bq} / \mathrm{g}$ ), which accounted for almost half of the total volume and was technically considered exempt from regulatory control (Paschoa et al. 1993). The other, called Goiânia Repository, was designed with more elaborate engineered barriers for the disposal of the higher activity radioactive wastes. The Abadia de Goiás facility has been officially closed with environmental restoration performed, as pictured in Figure 10 (Fleming and Mourão

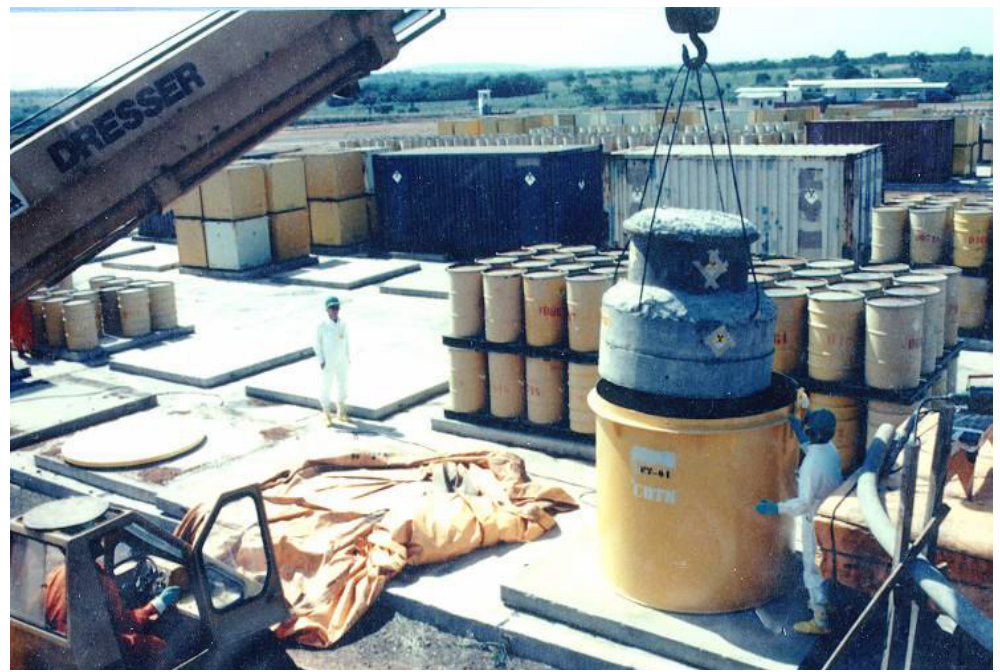

Figure 9. Temporary storage at Abadia de Goiás (FRB 2008) 2007; FRB 2008).

The radioactive waste volume generated by nuclear activities outside of the NPPs, including research, medical, and industrial application, is very small when compared to the figures mentioned above. Currently, all radioactive material is housed in temporary storage facilities, typically at or near the waste's point of generation (FRB 2008). 

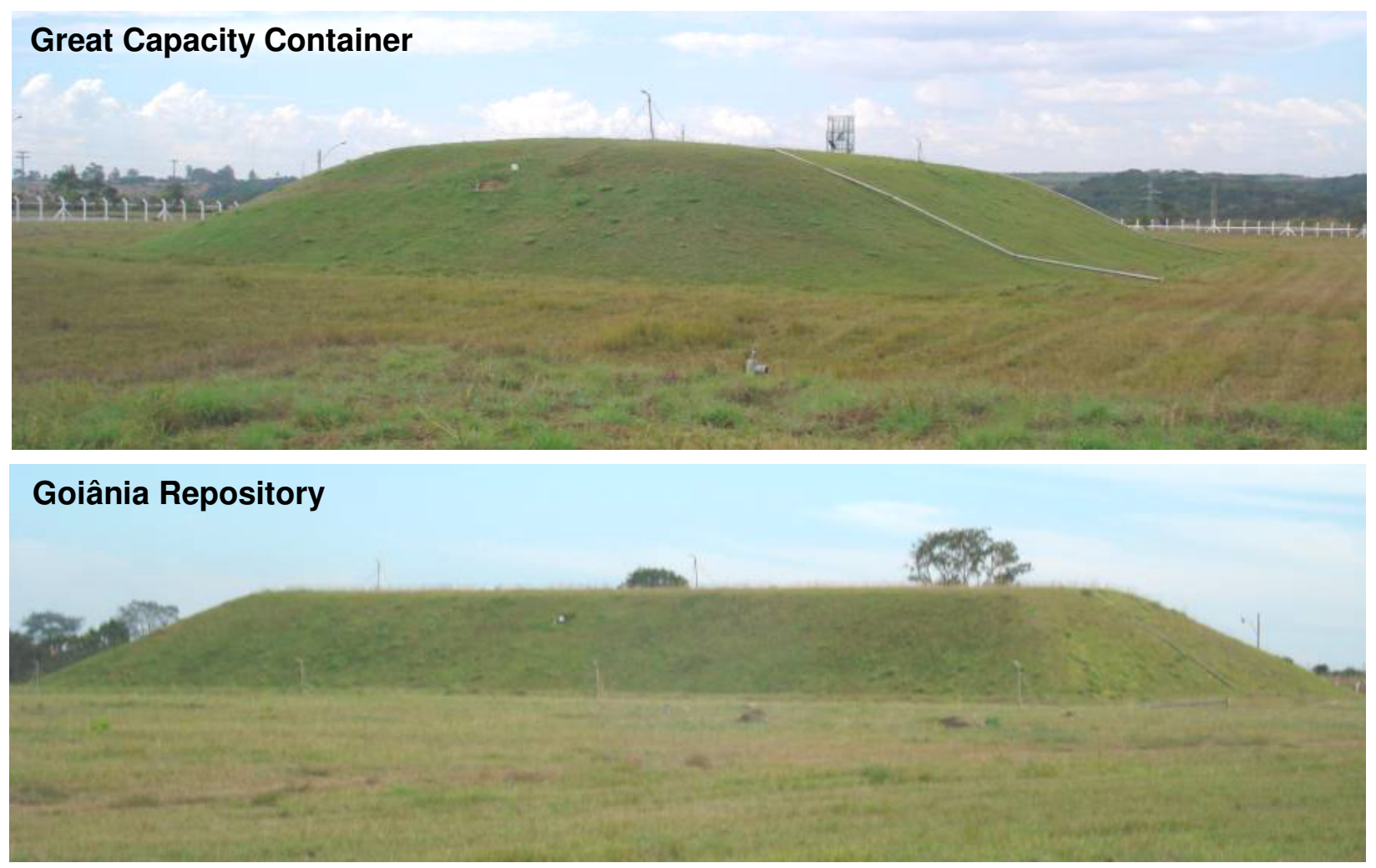

Figure 10. Repositories at Abadia de Goiás post-closure (FRB 2008)

\section{Current and Future Initiatives}

A Committee for Development of the Brazilian Nuclear Program (Comitê de Desenvolvimento do Programa Nuclear Brasileiro - CDPNB) was established in 2010 with the participation of 12 different ministries. This Committee approves governmental proposals in the areas of electric energy, fuel cycle, nuclear waste, medical, industrial and agricultural applications, organizational structure, human resources and international cooperation. These proposals include, among others, the construction of a national waste repository for medium and low level waste by 2018 (FRB 2010). Plans are currently under development and Government review, and the time frame for construction of the first module of the repository is estimated to be 5 years following final site selection and approval (FRB 2008).

\subsection{Bulgaria}

\section{Nuclear Capabilities}

Bulgaria has one operating nuclear power facility, Kozloduy, which supplies about 35 percent of the country's electricity and exports electricity to the Balkans. The Kozloduy facility has a total of six nuclear power units. However, in pursuance of the country's commitments associated with the accession to the European Union, reactor units 1 and 2 were shut in 2002 and units 3 and 4 followed in 2006. Currently, only two of the existing six reactors (units 5 and 6) are in operation; however, there are proposals to restart two others (units 3 and 4). A second NNP is 
being constructed in Belene, with an expected completion date of December 2013 (unit 1) and June 2014 (unit 2) (WNA 2011g; Bulg 2010).

\section{Regulation and Legislation}

The Energy Ministry is responsible for the nuclear power industry. The State Enterprise Radioactive Waste (SE RAW), also known by the Bulgarian acronym DP RAO, is the Bulgarian state-owned company responsible for the radioactive waste management in the country (Borissova 2007; WNA 2011g). The company was established at the beginning of 2004 and has a non-profit enterprise status. According to the Bulgarian legislation, the main activities of SE RAW include planning, implementation, and reporting of management of radioactive waste outside the site of generation; construction, operation and decommissioning/closure of radioactive waste management facilities; and establishment of waste acceptance criteria for long term management. The radioactive wastes become state property at their transfer to SE RAW, and SE RAW is responsible for the safety and security of the accepted waste and of the facilities where these waste are managed. The activities of SE RAW are subject to regulatory control according to the Act on the Safe Use of Nuclear Energy (Borissova 2007; IAEA 2009a) and are carried out in compliance with the requirements of the Joint Convention on Safety of Spent Nuclear Fuel Management and on Safety of Radioactive Waste Management, the IAEA radioactive waste management principles being applied (IAEA 2009a).

In 1992, two national funds were created under the Minister of Economy and Energy, one for the safe disposal of radioactive waste (Radioactive Waste Management Fund) and one for the decommissioning of nuclear facilities (Nuclear Facilities Decommissioning Fund) (WNA 2011g; IAEA 2009a; Borissova 2007). The real functioning of these Funds did not start until 1999, after approval of the corresponding Regulations. The funds are independent from the nuclear industry and managed by the government. The main contribution to the two funds comes from an electricity price levy specified by the Bulgarian Council of Ministers. The Kozloduy nuclear plant pays $3 \%$ of the price of its power into the waste management fund and a further $7.5 \%$ into the decommissioning fund (WNA 2011g).

National classification of radioactive waste is defined in the Regulation on Safety of Waste Management from 2004 and is substantially the same as the IAEA classification. Category 1, or transitional waste, corresponds to IAEA exempt waste. Categories $2 \mathrm{a}$ and $2 \mathrm{~b}$ are the same as IAEA's LILW-SL and -LL, respectively (IAEA 2011a).

\section{Waste Management Practices and Facilities}

The Kozloduy NPP site has its own on-site treatment, conditioning, and storage facility for the LILW radioactive waste generated during its own operation and decommissioning activities (WNA 2011g; IAEA 2009a). Since 2006, this radioactive waste management facility site has been a part of SE RAW. The management of the activities at the Kozloduy NPP facility is in compliance with the requirements of the Vienna Convention on Safety of Radioactive Wastes Management (RAW). The storage facility for the LILW is designed only for temporary storage prior to permanent disposal. It includes a combination of reinforced concrete trench-type surface disposal and warehouse building storage, which provides the necessary physical barriers between the stored waste and personnel and/or environment. Figure 11 shows reinforced concrete containers (RCC) used for conditioned LILW in temporary storage at the Kozloduy NPP site (SE RAW 2011). 
In December 2008, it was announced that units 1 and 2 were to be converted into radioactive waste management facilities and transferred to SE RAW. Pursuant to this decision, the Kozloduy NPP continued operating these units in shut down mode (i.e., without electricity and/or heat generation and storage of spent nuclear fuel at the reactor spent fuel pool) until the relevant licenses were obtained by SE RAW. In October 2010, the Bulgarian Nuclear Regulatory Agency issued licenses to SE RAW for the operation and management of units 1 and 2 as radioactive

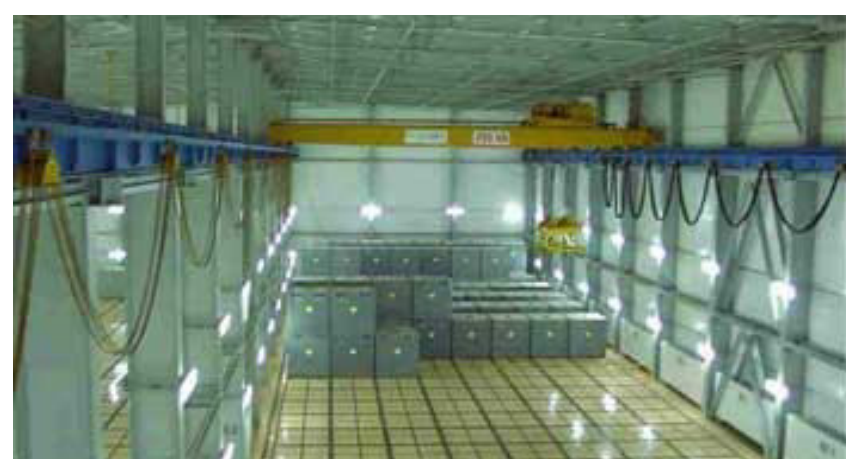

Figure 11. RCC placement in warehouse storage at the Kozloduy NPP (SE RAW 2011) waste facilities.

An additional near-surface repository Novi Han, in Losen Mountain about $35 \mathrm{~km}$ southeast of Sofia, was originally established and licensed in 1964 for non-nuclear radioactive wastes.



Figure 12. Temporary storage facilities at Novi Han (ENS 2006)
Managed by SE RAW (as of 2006), this permanent repository for radioactive waste (PRRAW) is the only existing repository in Bulgaria for final disposal of radioactive waste generated during the applications of radionuclides in medicine, research, and industry. Similar to the Kozloduy NPP facility, the LILW storage facilities also consists of a combination of trench and vaulttype surface disposal options with multi-layer engineered barriers. Currently the disposal vaults are out of operation (closed, but not sealed) and the radioactive waste are stored in temporary above ground storage facilities, as pictured Figure 12 (WNA 2011g; IAEA 2009a; Bulg 2010).

\section{Current and Future Initiatives}

In mid-2005, the Council of Ministers resolved that a national LILW disposal facility should be constructed by SE RAW for operation in 2015 and paid for from the radioactive waste fund. In April 2009, SE RAW awarded a three-year contract to a consortium responsible for site selection, design, safety assessment construction, and commissioning of the facility. Currently, the National Repository for RAW (NRRAW) is at the site selection stage (WNA 2011g; IAEA 2009a). Overall, 78 potential sites were initially studied, further narrowed down to 12 as most suitable for the locating a RAW repository, then four were pre-selected for site characterization. After expert assessment and analysis of the four candidate sites, the Radiana site was defined as the priority location. The Radiana repository and its facilities is situated on land of the village of Hurlets, in the Municipality of Kozloduy, and shall occupy approximately 90 acres (36 ha) within the boundaries of the 3-km radiation protection area of Kozloduy NPP (SE RAW 2011).

The NRRAW will be designed as a near surface multi-barrier modular engineered trench facility intended for disposal of conditioned and packaged short-lived LILW received from the operation of Kozloduy units 5 and 6, decommissioning activities of Kozloduy units 1 to 4 , future operation of Belene NPP, and other conventional non-NPP sources (e.g., medical, research, and 
industrial generators). The preliminary repository proposal envisages the construction of 8 uniform reinforced concrete modules (measuring $117 \mathrm{~m}$ in length, $35.5 \mathrm{~m}$ in width and $10 \mathrm{~m}$ in height), arranged in two parallel rows, as shown in Figure 13, with a total design capacity of nearly $140,000 \mathrm{~m}^{3}$ of LILW.

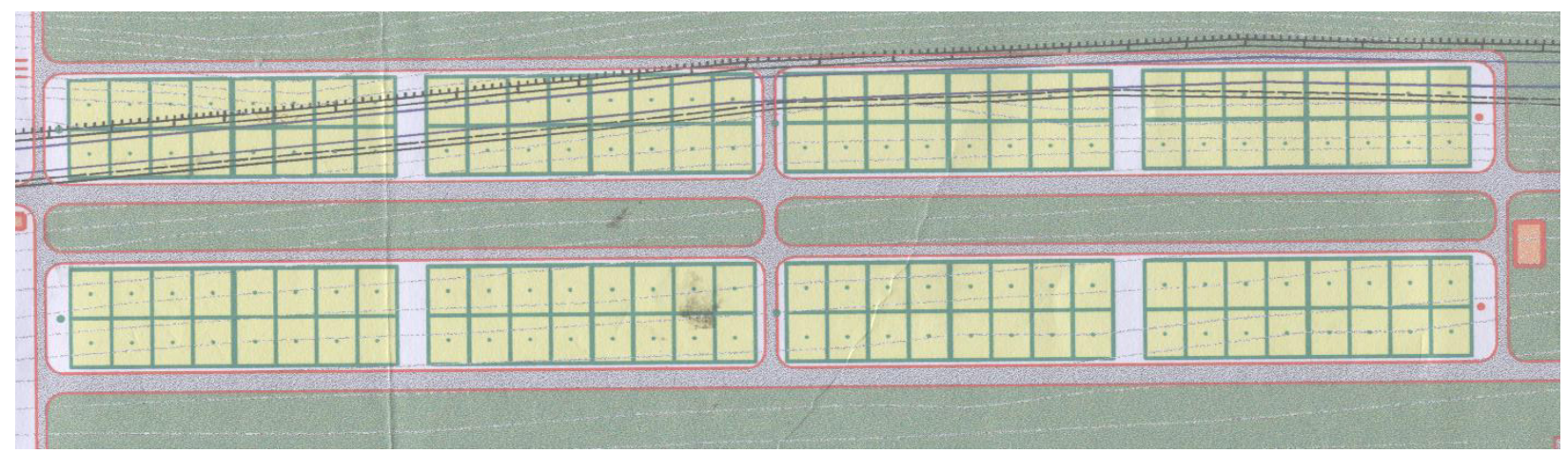

Figure 13. Positioning of disposal modules and chambers at the proposed Radiana Repository (SE RAW 2011)

The modules will be separated by longitudinal and transverse walls covered with waterproof material forming a sealed chamber. Each module consists of 16 identical reinforced concrete chambers (measuring $17 \mathrm{~m}$ long $\times 14 \mathrm{~m}$ wide), also located in two parallel rows of 8 chambers in a row. RCC containing the LILW are to be positioned in four rows and groups in the disposal chamber using a gantry crane, as illustrated in Figure 14, with approximately $90 \mathrm{~cm}$ empty space between each group allowing for inspections carried out during the operation period.

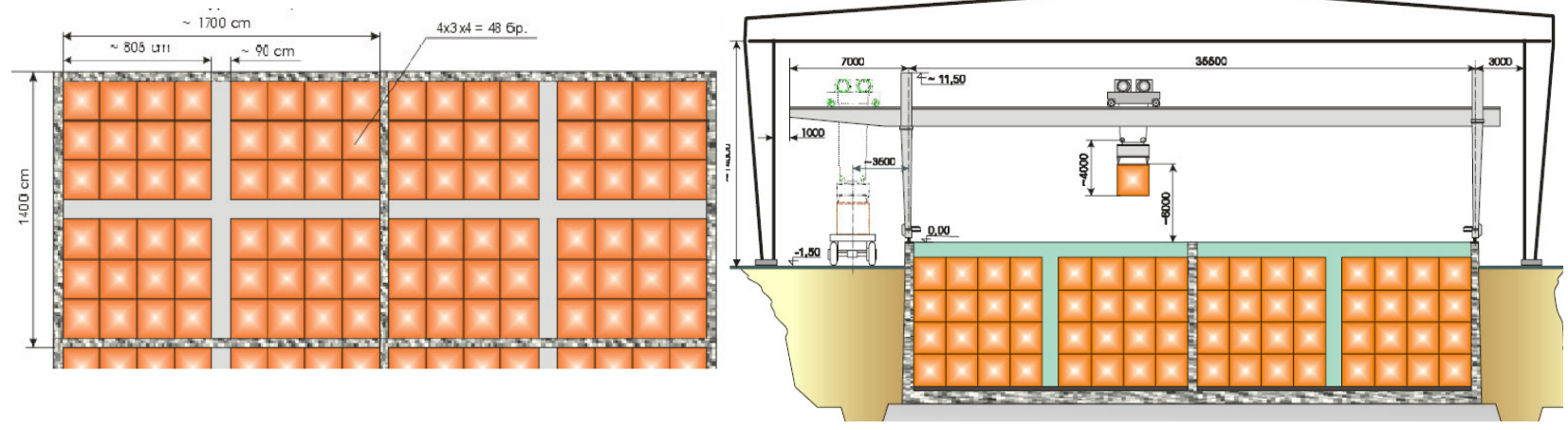

Figure 14. Overhead and cross sectional view of disposal chamber and RCC placement (SE RAW 2011)

During operation, the modules are covered by a temporary protective hall. On closing the module, empty space will be filled with grout containing an appropriate absorption material (e.g., zeolite) and a permanent reinforced concrete roof and multi-barrier protective cover will be placed. The multi-barrier protective cover will consist of a layer of sand for drainage, compacted clay for insulation from rainwater, sand and gravel mix for additional drainage, and soil stabilized by vegetation for erosion protection. An illustration of the exterior of the sealed repository is provided in Figure 15. Under the bottoms of the chambers reinforced concrete inspection galleries will be used to inspect the bottom of the disposal chambers and act as part of the leakage control system (SE RAW 2011). 


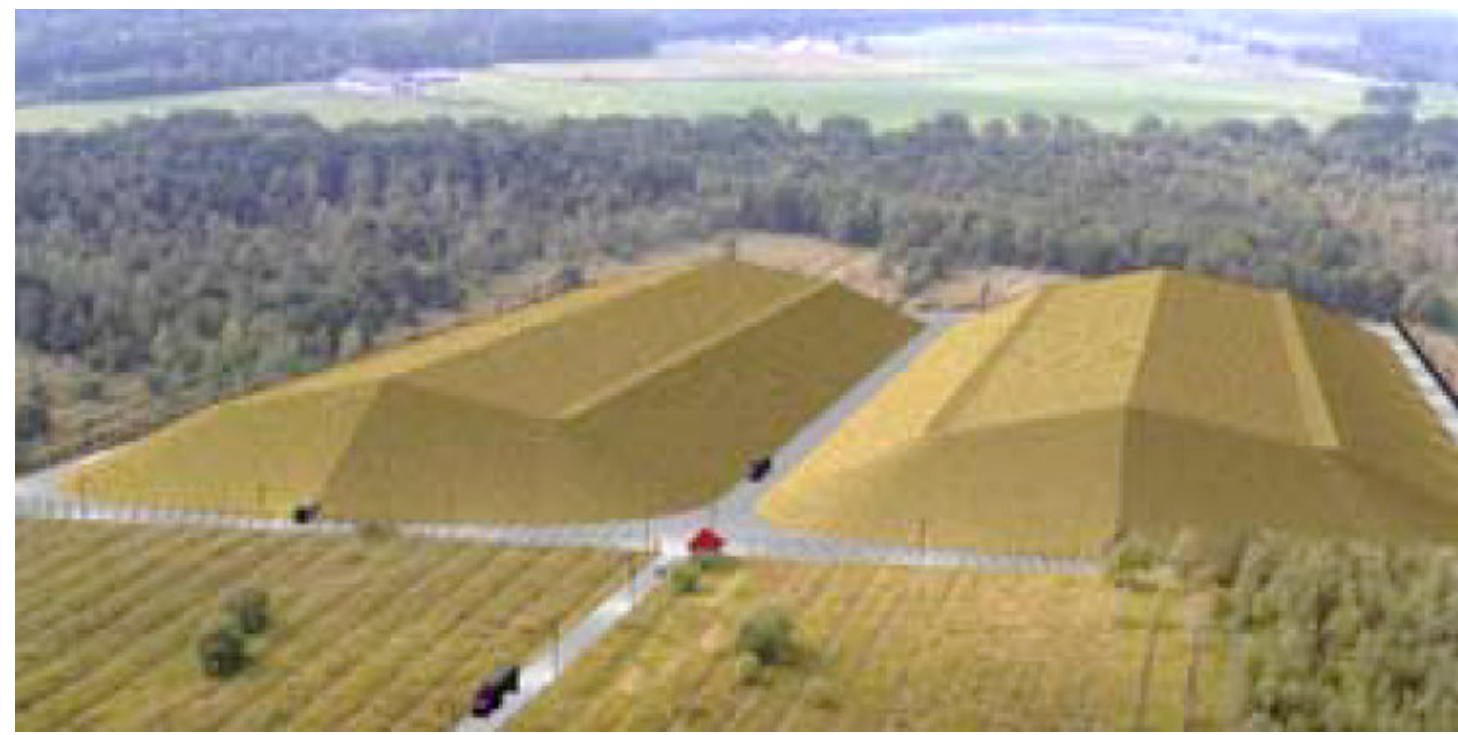

Figure 15. Sealed modular trench repository with built multi-barrier protective cover at the proposed Radiana Repository (SE RAW 2011)

\subsection{Canada}

\section{Nuclear Capabilities}

Radioactive waste has been produced in Canada since the early 1930s, when the first radium and uranium mine opened in Port Radium, Northwest Territories. The ore was transported to Port Hope, Ontario, where it was refined to produce radium for medical purposes and, later, uranium for nuclear fuel and military applications. Originating from research begun in 1944, when an engineering design team was brought together in Montreal, Quebec to investigate a heavy water moderated nuclear reactor, Canada has developed its own line of nuclear power reactors. Currently, Canada has eighteen operating nuclear power reactors (plus four in longterm shutdown), which produced nearly 15\% of Canada's electricity in 2008 (WNA 2011h; CNSC 2008). Canada plans to expand its nuclear capacity over the next 10 years by building as many as nine additional reactors. In addition, Canada has been a leader in nuclear research and technology operating eight research reactors, exporting reactor systems developed in Canada, as well as providing a high proportion of the world's supply of radioisotopes used in medical applications (WNA 2011h).

\section{Regulation and Legislation}

Canada's federal government has jurisdiction over nuclear energy, and Natural Resources Canada (NRCan) is the department responsible for nuclear energy and radioactive waste management policies. Canada's independent nuclear regulatory body, the Canadian Nuclear Safety Commission (CNSC), regulates the management of radioactive waste to ensure that it causes no undue radiological hazard to the health and safety of persons or to the environment. The government also established the Atomic Energy of Canada Limited (AECL) in 1952, with a mandate to research and develop peaceful uses of nuclear energy. The AECL also staffs and manages the Low-Level Radioactive Waste Management Office (LLRWMO), which is the national agent for the clean-up and management of Canada's historic waste. In 1996, the 
Government of Canada announced a Policy Framework for Radioactive Waste. The Framework sets the foundation for the further development of institutional and financial arrangements to manage and dispose of radioactive waste in a safe, environmentally sound, comprehensive, cost-effective, and integrated manner. The Policy Framework specifies that the federal government has the responsibility to develop policy, to regulate, and to oversee radioactive waste producers and owners in order that they meet their operational and funding responsibilities in accordance with approved disposal plans (IAEA 2003a; CNSC 2008). The Nuclear Waste Management Organization (NWMO) was set up under the 2002 Nuclear Fuel Waste Act (NFWA) by the nuclear utilities operating in conjunction with AECL. Its directive is to explore options for storage and disposal, to then make proposals to the government and to implement what is decided (WNA 2011h; IAEA 2011a; CNSC 2008).

Historic LLW in Canada refers to waste that was managed in the past in a manner no longer considered acceptable, but for which the current owner cannot reasonably be held responsible and for which the Government of Canada has accepted the long-term responsibility. In 1982, the Government of Canada established the LLRWMO within AECL as the federal agent for the cleanup and management of historic low-level radioactive waste in Canada. NRCan provides policy direction and funding to the LLRWMO, enabling it to carry out its work (CNSC 2008).

The Canadian Standards Association (CSA), in collaboration with industry and government, developed a standard radioactive waste classification system, which takes into account the IAEA Radioactive Waste Classification as well as the needs of the Canadian industry. The Canadian radioactive waste-classification system is organized according to the degree of containment and isolation required to ensure safety in the short- and long-term and takes into consideration the hazard potential of different types of radioactive waste. The system recognizes four main classes: HLW, ILW, LLW, and uranium mine and mill waste.

\section{Waste Management Practices and Facilities}

At present, radioactive waste is generated in Canada from the various stages and uses associated with the nuclear fuel cycle, including uranium mining and milling, refining and conversion, nuclear fuel fabrication, nuclear reactor operations, nuclear research, and radioisotope manufacture and use (CNSC 2008). In general, the producers of LILW all manage and operate storage facilities for their wastes. To date, LLW volumes in Canada are being safely stored on an interim basis (WNA 2011h; IAEA 2003a). Canadian methods for the management of radioactive waste place emphasis on minimization, volume reduction, conditioning, and temporary long-term storage of the waste. All radioactive waste currently generated is stored in such a way that it can be retrieved when permanent long-term management facilities become available (CNSC 2008).

The major nuclear utility in Canada, Ontario Power Generation (OPG), which owns 20 of Canada's 22 nuclear reactors, currently produces nearly 77 percent of the annual volume of LILW in Canada. The other major producer of LILW radioactive waste is the AECL, accounting approximately 17 percent of Canada's annual LILW volume. The AECL's mandate includes the management of the waste it generates from ongoing research, legacy radioactive waste and decommissioning liabilities on its properties, as well as for the waste it accepts for long-term management from non-utility radioactive waste producers across Canada on a fee-for-service basis (which amounts to a further three percent of Canada's annual volume). The other two nuclear power reactors, owned by New Brunswick Power Corporation (NB Power) and HydroQuébec ( $\mathrm{HQ})$, and Cameco Corporation's uranium processing and conversion facilities in Ontario generate most of the remaining waste (CNSC 2008). 
Radioactive wastes resulting from nuclear reactor operations are stored in a variety of structures located in waste management facilities at the various nuclear reactor sites. Prior to storage, the volume of the wastes may be reduced by incineration, compaction, shredding, or baling. In addition, there are facilities for the decontamination of parts and tools, laundering of protective clothing and the refurbishment and rehabilitation of equipment. In general, LLW is stored in above ground storage buildings and ILW is stored in either in-ground structures (including trenches, concrete vaults, vertical cylindrical concrete tile holes, and other containers) or aboveground engineered structures (including shielded buildings and specially designed quadricells) (WNA 2011h; CNSC 2008; Orr 2007). The majority of LILW produced as a result of OPG's nuclear power reactors is stored in a central location at the Western Waste Management Facility (WWMF), which it has operated since 1974 at the Bruce Nuclear Power Development (BNPD) site in Kincardine, Ontario (WNA 2011h; CNSC 2008). The WWMF, pictured in Figure 16, includes a waste volume reduction building for the receipt of wastes and compaction, shredding, baling, and incineration prior to storage. The LILW storage areas include low-level storage buildings, refurbishment waste storage buildings, quadricells, in-ground containers, trenches, and tile holes. As of December 2007, the inventory at the WWMF included more than $66,000 \mathrm{~m}^{3}$ of LLW and $9,300 \mathrm{~m}^{3}$ of ILW. NB Power and HQ have their own LILW storage facilities on site at their nuclear reactor facilities, with a combined inventory of only $760 \mathrm{~m}^{3}$ of LLW and less than 60 $\mathrm{m}^{3}$ of ILW (CNSC 2008).

Regarding research and development, AECL has waste storage facilities at its two laboratory sites: Chalk River Laboratories (CRL) in Renfrew County, Ontario and shutdown Whiteshell Laboratories in Pinawa, Manitoba, as well as at its three prototype research reactor sites (Nuclear Power Demonstration (NPD) reactor in Rolphton, Ontario; Douglas Point reactor in Kincardine, Ontario; and Gentilly-1 reactor in Bécancour, Quebec) (NLLP 2010; Metcalfe et al. 2009). AECL storage facilities for LLW include sand trenches, and engineered bunkers, and shielded above-ground storage buildings (illustrated in Figure 17); while ILW is typically stored in in-ground concrete bunkers or tile holes.

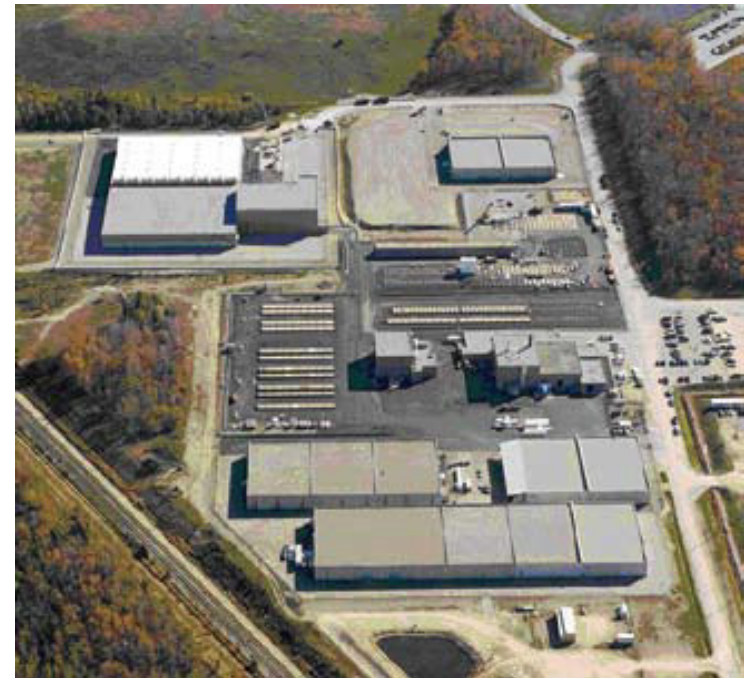

Figure 16. Western Waste Management Facility (CNSC 2008)

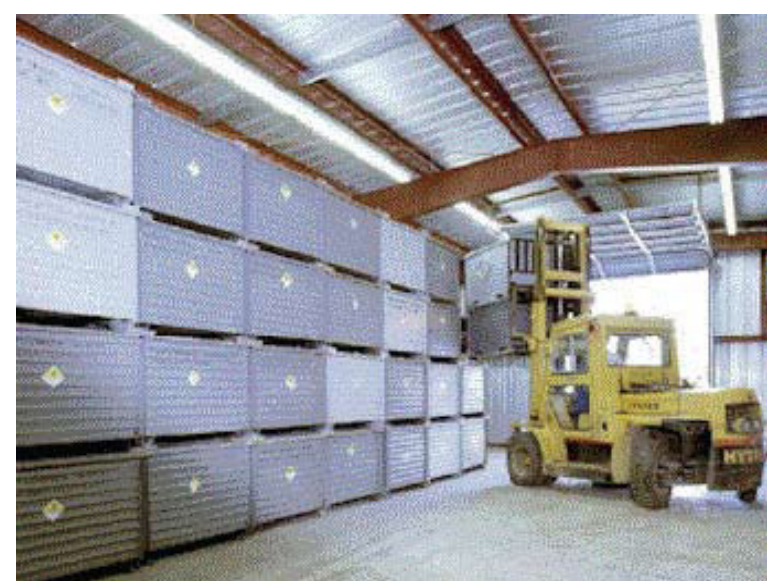

Figure 17. Modular above-ground storage (MAGS) structure at CRL (CNSC 2008)

The CRL site, which covers nearly 9,900 acres (4,000 ha), was established in the mid-1940s, and has a history of various nuclear operations and facilities, primarily related to research. The $\mathrm{CRL}$ also provides some fee-based waste management for institutions such as universities, hospitals, and industrial users, which have no other means to manage their wastes. As of 
December 2007, the various active and closed LILW waste management areas (WMAs) located within the CRL property hold a combined inventory of more than 95,000 $\mathrm{m}^{3}$ of LLW and 18,000 $\mathrm{m}^{3}$ of ILW. The Whiteshell Laboratories (WL) facility is a nuclear research and test establishment comprised of a number of facilities, including a research reactor, shielded facilities, and research laboratories. The WL site has one WMA, which has been in operation since 1963, contained nearly $20,000 \mathrm{~m}^{3}$ of LLW and $900 \mathrm{~m}^{3}$ of ILW at the end of 2007 (CNSC 2008).

Canada's historic LLW inventory, which amounts to roughly 2 million $\mathrm{m}^{3}$, consists largely of radium and uranium contaminated soils. The bulk of this historic LLW is located in the southern Ontario communities of Port Hope and Clarington (Port Granby) and originates from the operations of a radium and uranium refinery in the dating back to the 1930s. Most of the remaining historic waste is located along the Northern Transportation Route and is a result of the past transport of radium and uranium bearing ore and concentrates from the Port Radium Mine in the Northwest Territories to the barge-to-rail transfer point at Fort McMurray, Alberta. From 1975 to 1982, the Atomic Energy Control Board (AECB), now the CNSC, on behalf of the Federal-Provincial Task Force on Radioactivity, carried out a cleanup of developed residential, public and commercial properties. Since then, the LLRWMO has conducted further historic waste investigations and cleanups across Canada and continues to monitor, inspect, and maintain several sites. At some of the sites, materials have been placed in interim storage pending the development of a long-term management approach. For example, the Welcome Waste Management Facility, located in Port Hope, has approximately $500,000 \mathrm{~m}^{3}$ of historic LLW stored from 1944 until its closure in 1955 at the facility from Eldorado's former uranium refining operations (PHAI 2011; MPH 2009; CNSC 2008).

\section{Current and Future Initiatives}

Canada's two major LILW producers and owners, OPG and AECL, currently have initiatives underway to develop and implement long-term management solutions. In October 2004, OPG entered into an agreement with the Municipality of Kincardine to host a Deep Geologic Repository (DGR), on the Bruce Nuclear Power Development (BNPD) site, designed to hold current and future LILW from OPG's 20 reactors (CNSC 2008). OPG will be the owner and licensee of the DGR; however, NWMO was contracted to manage development of the DGR from the beginning of 2009. The DGR concept, illustrated in Figure 18, is composed of horizontally excavated emplacement rooms, which will be arranged in two panels with access provided via two vertical, concrete-lined shafts. The DGR is planned for a depth of approximately between 660 and $680 \mathrm{~m}$ beneath the WWMF and will be constructed to meet international and Canadian safety standards with a high margin of safety. In 2007, two deep boreholes were drilled to confirm the expected stratigraphy at the site. More than $200 \mathrm{~m}$ of lowpermeability shale (as illustrated in Figure 18) form a protective cap over the low-permeability limestone formation where the repository will be constructed. The environmental impact assessment and licensing is expected to take 6-8 years, beginning with the submission of the environmental assessment to CNSC in April 2011, followed by issuance of a construction license in 2012, and full service operation beginning around 2017-18 (WNA 2011h; CNSC 2008).

In 2006, the Government of Canada adopted a new long-term strategy to deal with the nuclear legacy liabilities that have resulted from more than 65 years of nuclear research and development carried out on behalf of Canada by the National Research Council (1944 to 1952) and AECL (1952 to present). The overall objective of the Nuclear Legacy Liabilities Program (NLLP) is to safely and cost-effectively reduce the liabilities and associated risks over a 70-year 

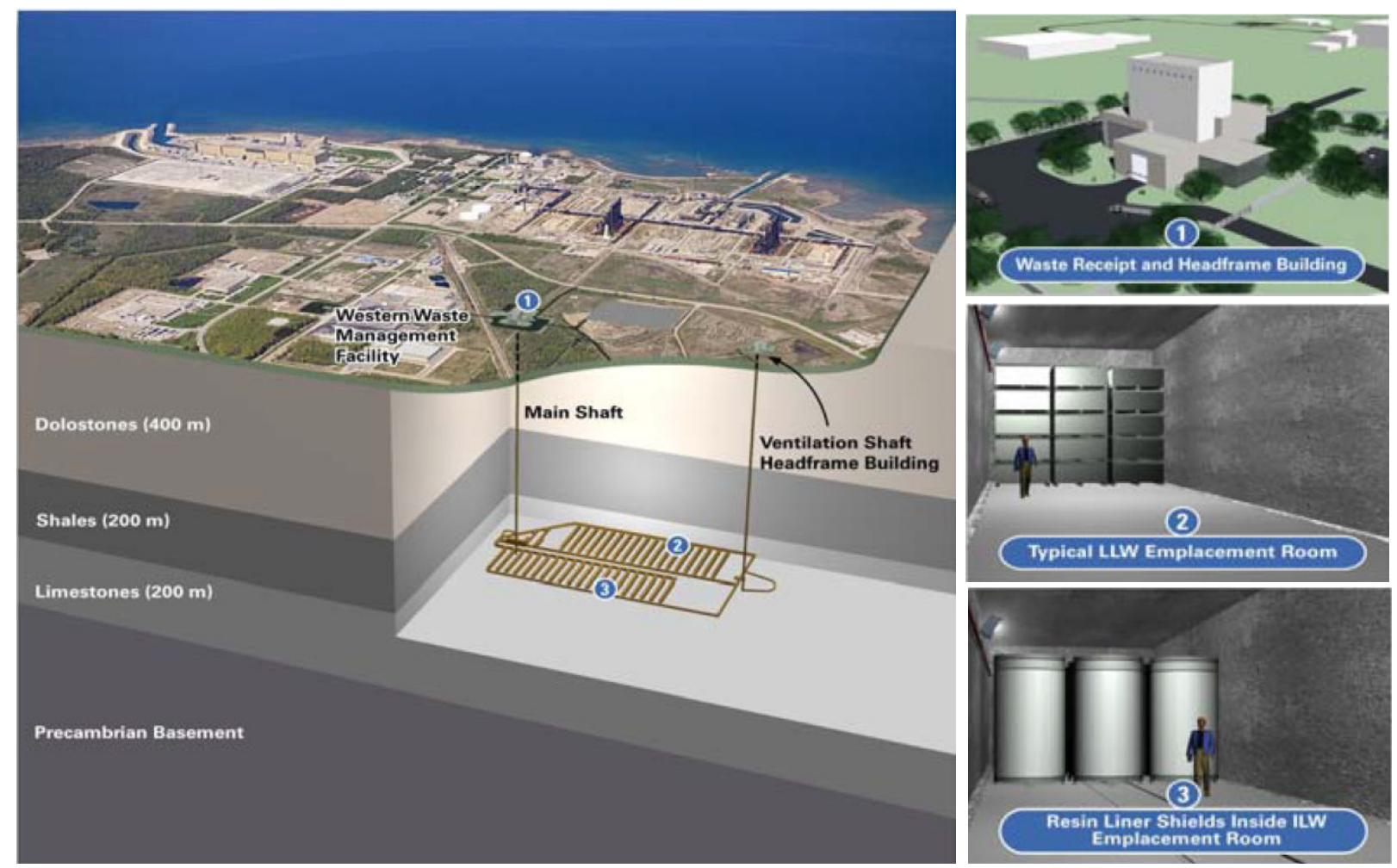

Figure 18. Proposed Deep Geologic Repository for L\&ILW on the BNPD Site (Orr 2007)

period (NLLP 2010; Metcalfe et al. 2009). Several studies are being initiated to better define the waste processing, treatment, and long-term management facilities necessary to deal with the wide variety of legacy waste types that exist at all AECL sites (NLLP 2010; Metcalfe et al. 2009; CNSC 2008). A number of the studies underway support the evaluation of the CRL site for a deep repository to serve the long-term management of AECL's inventory of solid LILW. These studies include the complication of existing geologic information, installation of micro-seismic activity monitors, and exploratory drilling of boreholes to obtain the necessary geochemical data to assess the suitability of site geology (Metcalfe et al. 2009; CNSC 2008). As the long-term strategy is further developed and refined, public consultations will be carried out to inform this work and the decisions on next steps.

In regards to legacy LLW, the Government of Canada recognizes that, although there are no urgent risks from a health or environmental standpoint, intervention measures are required in order to implement more appropriate long-term management measures for these materials. In March 2001, the Government of Canada and the local municipalities partnered on community developed proposals to address the cleanup and long-term management of these wastes, thereby launching the Port Hope Area Initiative (PHAI). The PHAl will result in the long-term management of these historic wastes in two aboveground mounds that will be constructed in the local communities (CNSC 2008). The initiative includes two projects, the Port Hope Project (planned as an extended site of the existing Western Waste Management Facility (WWMF) and Port Granby Project, both of which are currently in the environmental assessment and regulatory review phase, which is expected to be completed in late 2011. Figure 19 and Figure 20 provide a conceptual design illustration and cross sectional view of the disposal mound for the Port Hope and Port Granby Projects, respectively. Both proposed facilities will be above ground disposal mounds designed to isolate the historic LLW by securely encasing it on the top, bottom and sides with thick, multiple layers of natural and specially manufactured materials. 
These layers form components (cover and baseliner) that, independently, are robust enough to prevent contaminants from entering the environment. Together, they function as multiple, backup safety systems. The construction and development phase will continue for several years until the waste is safely transported and emplaced in the new facilities. After the waste has been emplaced, control systems with sensors and testing wells will be installed within and around the mounds that will monitor the waste for hundreds of years (Fahey 2010; PHAI 2011).
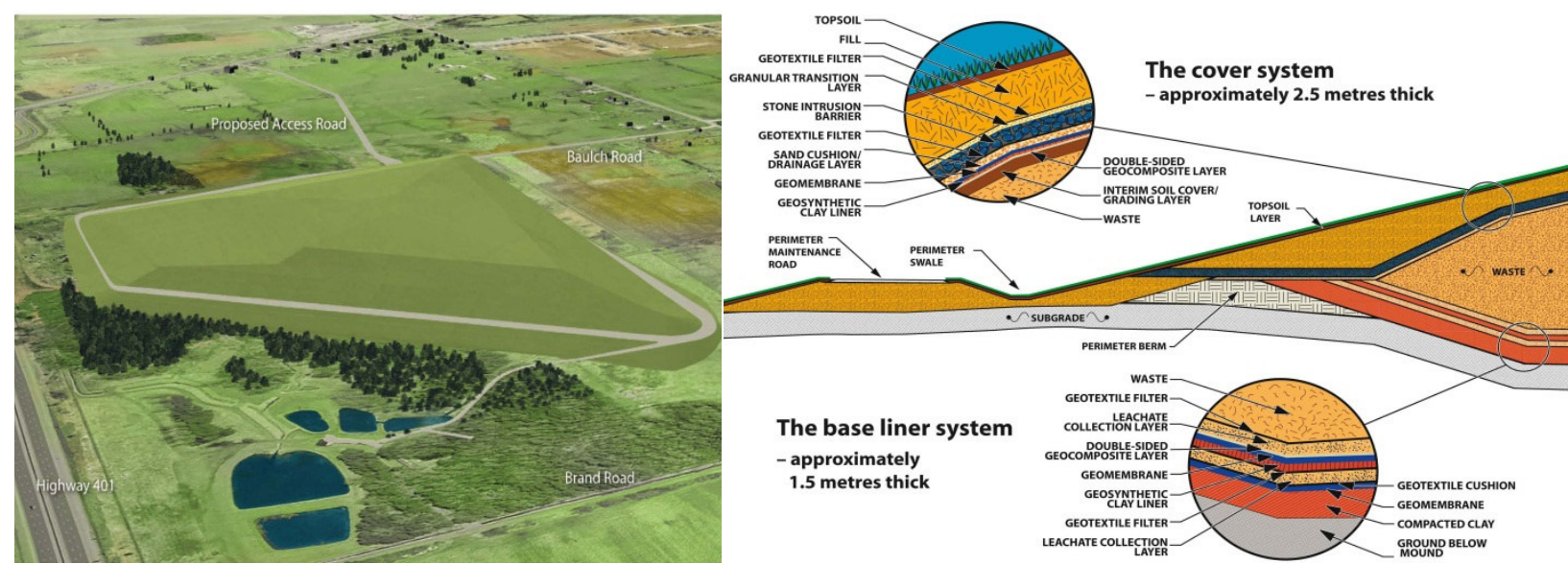

Figure 19. Conceptual design for the Port Hope Project at the site of WWMF (PHAI 2011)
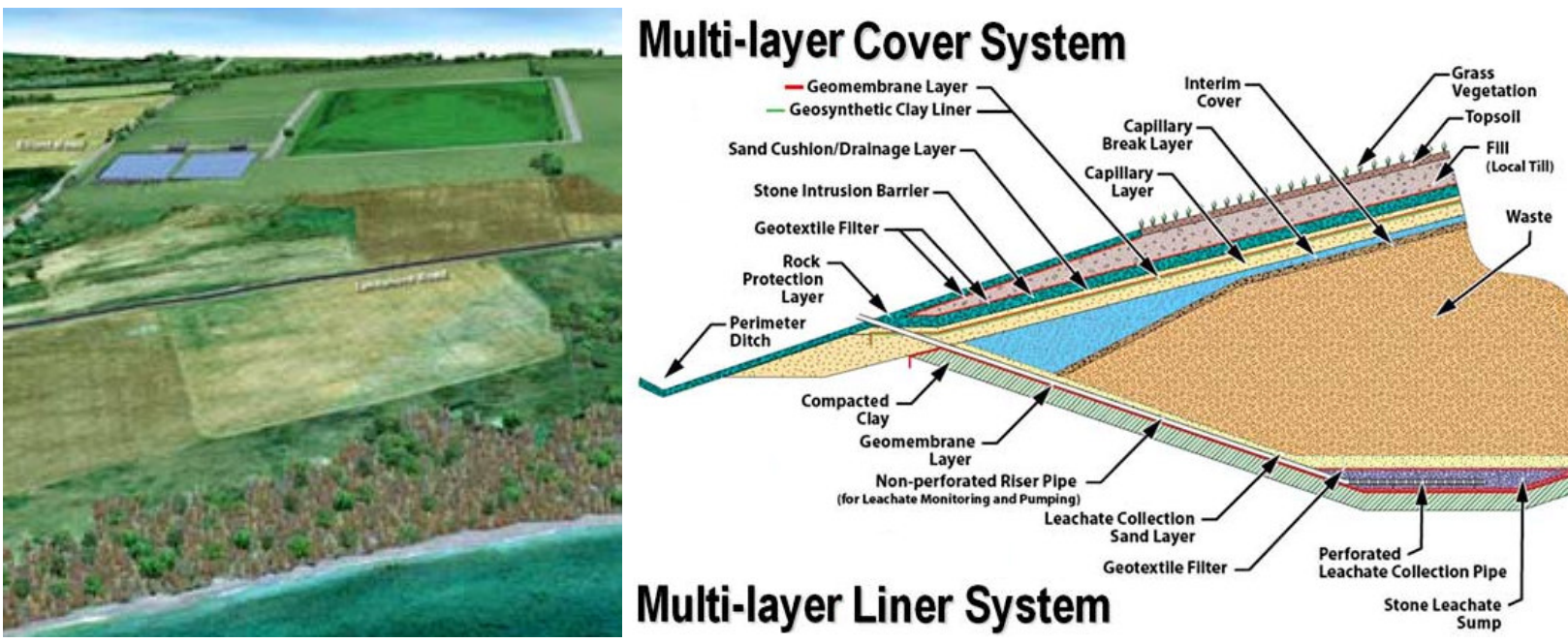

Figure 20. Conceptual design for the Port Granby Project (PHAI 2011)

\subsection{China}

\section{Nuclear Capabilities}

The People's Republic of China (China) is the world's most populous country and the second largest energy consumer (after the United States). Most of mainland China's electricity is produced from fossil fuels $(74 \%$ in 2010$)$ and hydropower $(22 \%)$, with wind and nuclear power at only about three and one percent, respectively. However, nuclear power has an important role, especially in the coastal areas remote from the coalfields and where the economy is 
developing rapidly. Currently, mainland China has 15 nuclear reactors in operation, 27 under construction, more than 20 in the planning phase, and about 140 additional ones being proposed, including some of the world's most advanced technologies drawn from France, Canada, and Russia. China is rapidly becoming self-sufficient in both nuclear reactor design and facility construction (WNA 2011i). In addition to the nuclear industry, there are currently more than 50,000 institutions producing, selling, and/or using radioisotopes and irradiation facilities in China (NNSA 2009).

\section{Regulation and Legislation}

China's nuclear licensing and regulatory body, National Nuclear Safety Administration (NNSA), was set up in 1984 and maintains international agreements regarding safety. The NNSA is currently under the China Atomic Energy Authority (CAEA), which plans new capacity and approves feasibility studies for new plants. Thus, the NNSA is not technically an independent authority, even though it reports directly to the State Council. The State Environment Protection Administration (SEPA), now elevated to a Ministry of Environmental Protection (MEP), is the department directly under the State Council responsible for radiological monitoring and radioactive waste management. The China National Nuclear Corporation (CNNC), established by the State Council in 1988 as a self-supporting economic entity, controls most nuclear sector business including $R \& D$, engineering design, uranium exploration and mining, enrichment, fuel fabrication, reprocessing, and waste disposal. It also claims to be the major investor in all nuclear plants in China (WNA 2011; WNA 2011j; IAEA 2003b).

Radioactive waste classification for the purposes of disposal is regulated in the Radioactive Pollution Prevention and Control Act (2003). This act revised the earlier standards, originally set 1988 , and was based on the updated IAEA radioactive waste classification scheme. In general, specific activity for the LLW categorization shall not exceed $4,000 \mathrm{~Bq} / \mathrm{g}$; whereas, the ILW categorization falls between 4,000 and $400,000,000 \mathrm{~Bq} / \mathrm{g}$, depending on half-life and heat release rate, which shall not exceed $2 \mathrm{~kW} / \mathrm{m}^{3}$. Disposal options for LILW are categorized as near-surface disposal. This act also separates naturally occurring radioactive material (NORM) from nuclear application wastes, which are further classified according to the waste characteristics and processing approach (China 2008; FNCA 2007).

\section{Waste Management Practices and Facilities}

Radioactive waste management facilities can be grouped into three sub-categories: on-site treatment and storage, provincial storage, and regional disposal. Each NPP and most the largescale nuclear facilities, such as fuel manufacture plant, also have their own treatment and storage facilities for radioactive waste. The treatment facilities can include waste segregation, incineration, solidification, cementation, and compaction (FNCA 2007). For decommissioning activities, on-site storage, via permanent emplacement in an engineered near surface structures, has been used as a disposal option for large volume and very low-level activity waste (Wen and Liu 2007).

In order to keep pace with the development of nuclear technology application, temporary radioactive waste storage facilities of different scales have been constructed in China since the 1960's. These provincial storage facilities were designed for interim storage of radioactive wastes arising from nuclear applications, primarily accepted from hospitals, universities, and nuclear technique applications. By the end of 2006, these temporary storage facilities had received on the order of $1,300,000 \mathrm{~kg}$ radioactive waste in total (China 2008). In recent years, China has developed a national project to specifically handle the country's radioactive waste 
produced outside of the nuclear power industry. This project, which has put into trial at the provincial level, includes building national Urban Radioactive Waste Storage Repositories. By the end of 2009, 23 repositories were completed, 4 provincial storages had been caped, and 4 facilities were still incomplete. Much of the disused radioactive sources and waste, which had historically been stored in the provincial radioactive waste storages, has been transported to the national Urban Repositories for centralized management and regulation (NNSA 2009; China 2008; FNCA 2007).

Siting work for regional LILW repositories was initiated in the 1980s and conducted in South China, East China, Northwest China, and Southwest China based on the distribution of nuclear facilities at the time. Currently, regional scale disposal of LILW from the nuclear industry, institutions, and NPPs is available at two near surface repositories located in the Northwest (Northwest LILW Repository) and South (Beilong LILW Repository). Underground and partial underground disposal methods are employed at these two repositories using a multilayer combination of engineered and natural barriers to cover the top. During the emplacement of waste, the disposal cell is equipped with a mobile rain shelter, which is used to prevent raining intrusion. There is also a pipeline network below the disposal cells, which is designed to deliver infiltrating water to a collection tank and monitoring stations (FNCA 2007; Xiande 1999).

The Northwest LILW Repository is located near Yumen in northwest Gansu province near the Gobi desert. The disposal cells consist of concrete vaults with a compacted soil foundation and reinforced cement top plate. After placement, the space between waste drums would be backfilled with sandy soil. At closure, the top of each unit will be covered with $2 \mathrm{~m}$ thick overburden. With a total design capacity of $200,000 \mathrm{~m}^{3}$, the Northwest Repository is in trial operation with first phase capacity of $20,000 \mathrm{~m}^{3}$ (completed in 1998). By the end of 2009, Northwest had accepted approximately $3,300 \mathrm{~m}^{3}$ LILW that totaled nearly 6,700 barrels/boxes.

The Beilong LILW Repository is situated in Guangdong province, near the Daya Bay NPP in South China. The disposal cells consist of reinforced concrete vaults with a concrete slab bottom and caps. Following placement, the space between waste drums will be backfilled with sand and cement grout. After closure, the top of each unit will be covered with $5 \mathrm{~m}$ thick overburden. According to the facility design, the repository can handle a total of $240,000 \mathrm{~m}^{3}$ of waste, with the first phase capacity of $80,000 \mathrm{~m}^{3}$. Three of the disposal cells have already been constructed and have accepted approximately 350 waste packages for temporary storage, as of the end of 2009 (WNA 2011a; NNSA 2009; FNCA 2007; China 2008). In addition, China has a national centralized storage facility for disused radioactive sources that serves as the storage site for legacy disused source of nuclear industry and has accepted more than 4,200 disused source packages, as of the end of 2009 (NNSA 2009).

\subsection{France}

\section{Nuclear Capabilities}

France is currently the world's largest exporter of electricity and gains over $€ 3$ billion per year from this. Over the last decade, France has exported power to Belgium, Germany, Italy, Spain, Switzerland, and the United Kingdom (UK). However, this was not always the case. In the early 1970 's, France was importing more than $75 \%$ of national energy consumption, since French indigenous natural fossil fuel resources were limited and costly. This situation turned around in 1974, just after the first oil crisis, when the French government first established its current long- 
standing policy based on energy independence and security. These new energy policies lead to the implementation of a large nuclear power program, which provided a solution to minimize energy imports, stabilize prices, and achieve greater energy security. The share of nuclear power in primary energy supply increased from less than 2 percent in the late 1970s to about one third in the mid-1990s and reached 42 percent by 2005. Today, France derives about threequarters of its electricity from 19 NPPs, with 58 total reactors, which are operated by Electricité de France (EdF) and regulated by the French Nuclear Safety Authority (Autorité de Sûreté Nucléaire, ASN). In addition, France has 11 research reactors, 10 of which are operated by the French Atomic Energy Commission (CEA) and 1 operated by the Institut Laue-Langevin (ILL), a research institute grouping several European partners. France is also currently building its first Generation III commercial reactor, with a second in the planning stages, which will offer significant safety, efficiency, and economic improvements over the current Generation II reactor designs (WNA 2011k; Rep Fra 2010; IAEA 2006c). The country has a policy of reprocessing, the used nuclear fuel from the French reactors is sent to La Hague plant in Normandy for reprocessing, and about 17\% of France's electricity is from reprocessed fuel (WNA 2011k)

\section{Regulation and Legislation}

Within the French Government, the Ministry for Ecology, Energy, Sustainable development and Town and country planning (Le ministère de l'Écologie, de l'Énergie, du Développement durable et de l'Aménagement du territoire) is the agency with responsibility for radioactive waste management. Actual waste management and disposal is pursued under France's 1991 Waste Management Act, which established the National Radioactive Waste Management Agency (Agence nationale pour la gestion des déchets radioactifs, or ANDRA) as the independent agency tasked with managing the nation's radioactive waste. In 2006, the National Assembly and Senate passed the Nuclear Materials and Waste Management Program Act, which defined a roadmap for management of all radioactive waste, in particular by requiring the National Plan for the Management of Radioactive Materials and Waste (PNGMDR) (PNGMDR 2006). The PNGMDR constitutes the key element in the leadership of the French National Management Policy. Its purpose is the creation of a national management plan defining the solutions, goals to be achieved, and research actions required to reach these goals. This plan is updated every three year and published according to the law on nuclear transparency and security (WNA 2011k; ASN 2009; Rep Fra 2008; IAEA 2006c).

Financial provisions have been annually made by most of the nuclear plants operators for future waste management and dismantling of the existing plants. For example, the EdF sets aside $€ 0.14$ per kilowhatt-hour (kWh) of nuclear electricity. The Parliament will participate in the control of those financial provisions as dedicated assets in the companies' accounts (WNA 2011k; IAEA 2011a).

France classifies its nuclear waste based on origin, disposal options, and the nature of waste, which includes activity level, and half-lives of main radionuclides. Half-lives are divided into very-short (less than 100 days), short (between 100 days and 31 years), and long (over 31 years). The French waste classes, which do not exactly correspond to any of IAEA classes, include: VLLW; LILW, short-lived; LLW, long-lived; ILW, long-lived; and HLW. VLLW mainly originates from the operation, maintenance, and dismantling of NPPs, fuel-cycle facilities, and research establishments. Its activity level is close to that defined for exempt waste, and cannot be assimilated to any of the IAEA classes. The disposal option is a surface repository. Short lived LILW results mainly from the operation and dismantling of nuclear power plants, fuel-cycle facilities, and research establishments. Long-lived LLW is comprised mainly from former NPP's 
graphite waste and non-nuclear industrial radium-bearing waste. These 2 classes fall roughly between two of the IAEA classifications, LILW-SL and LILW-LL. The disposal option for these wastes is a near or sub-surface repository (IAEA 2011a; Rep Fra 2008; PNGMDR 2006).

\section{Waste Management Practices and Facilities}

Most current and historical short-lived LILW has been sent for final disposal to an ANDRA operated surface waste repository. There are two such repositories in France: Centre de la Manche and Centre de l'Aube. The Centre de la Manche Repository, pictured in Figure 22, was set up in 1969 at Digulleville, in the Cotentin Peninsula (Normandy), as the first French nearsurface radioactive waste disposal facility. It was initially run by a private company, INFRATOME, and regulated by the CEA through a technical liaison committee. The Centre de la Manche facility occupies an area of about 37 acres (15 ha) and has a total design capacity of approximately $530,000 \mathrm{~m}^{3}$ (ANDRA 2011a). At the start of operation, the waste was either buried directly in earthen trenches according to the activity of the waste packages. After one year of operation, the earth trenches were deemed unsafe and dismantled. Waste packages


Figure 21. Waste package placement and mound closure coverings at Centre de la Manche LILW Repository (ANDRA 2009)

were instead stacked on naturally layered or reinforced concrete platforms, as illustrated in Figure 21A. The voids between the packages were filled with gravel and covered with a layer of gravel and soil to form mounds, as illustrated in Figure 21B and C. The buried concrete trenches were also abandoned in the early 1980's and replaced by prefabricated reinforced

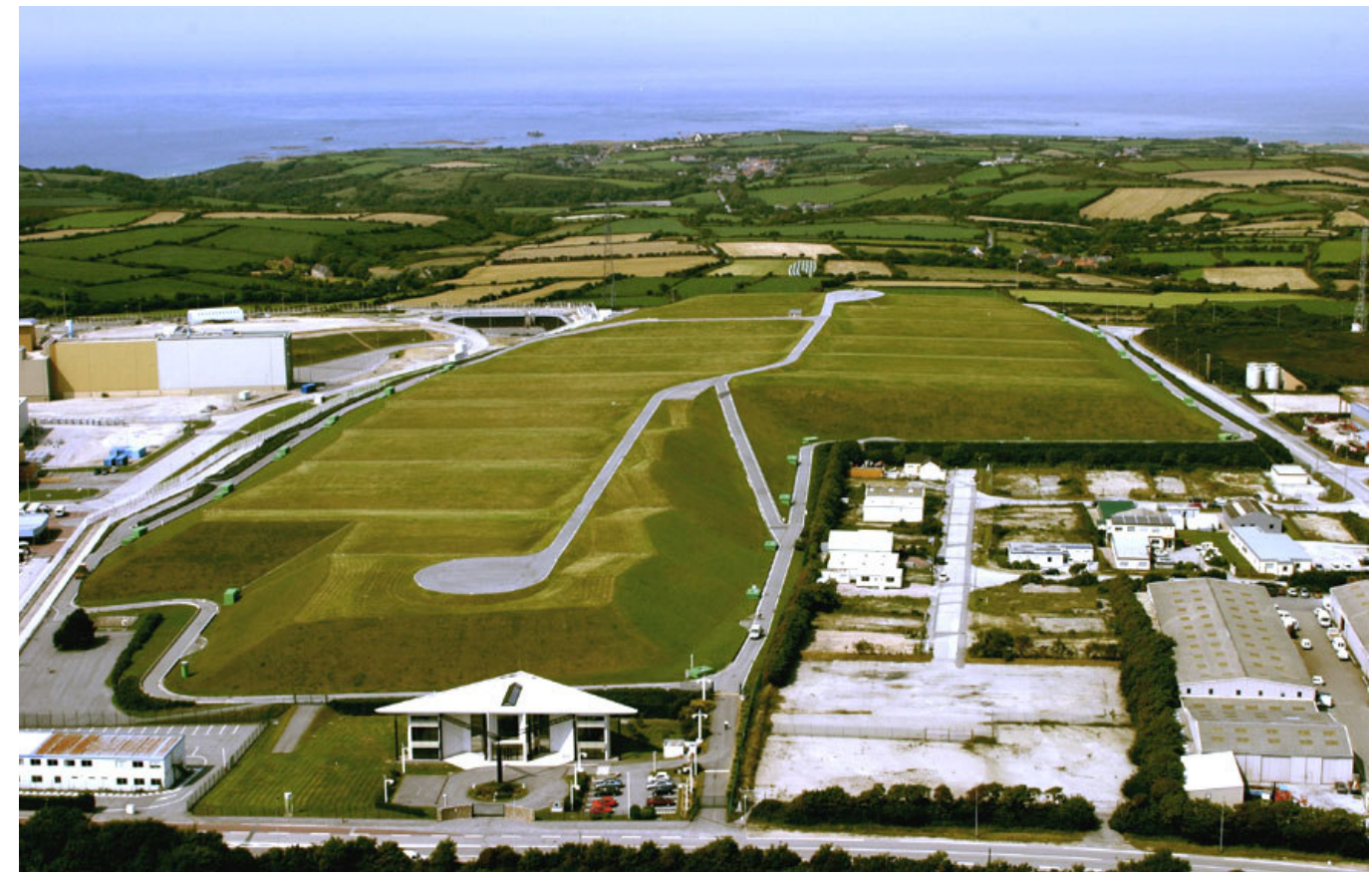

Figure 22. Centre de la Manche LILW Repository (ANDRA 2011a) 


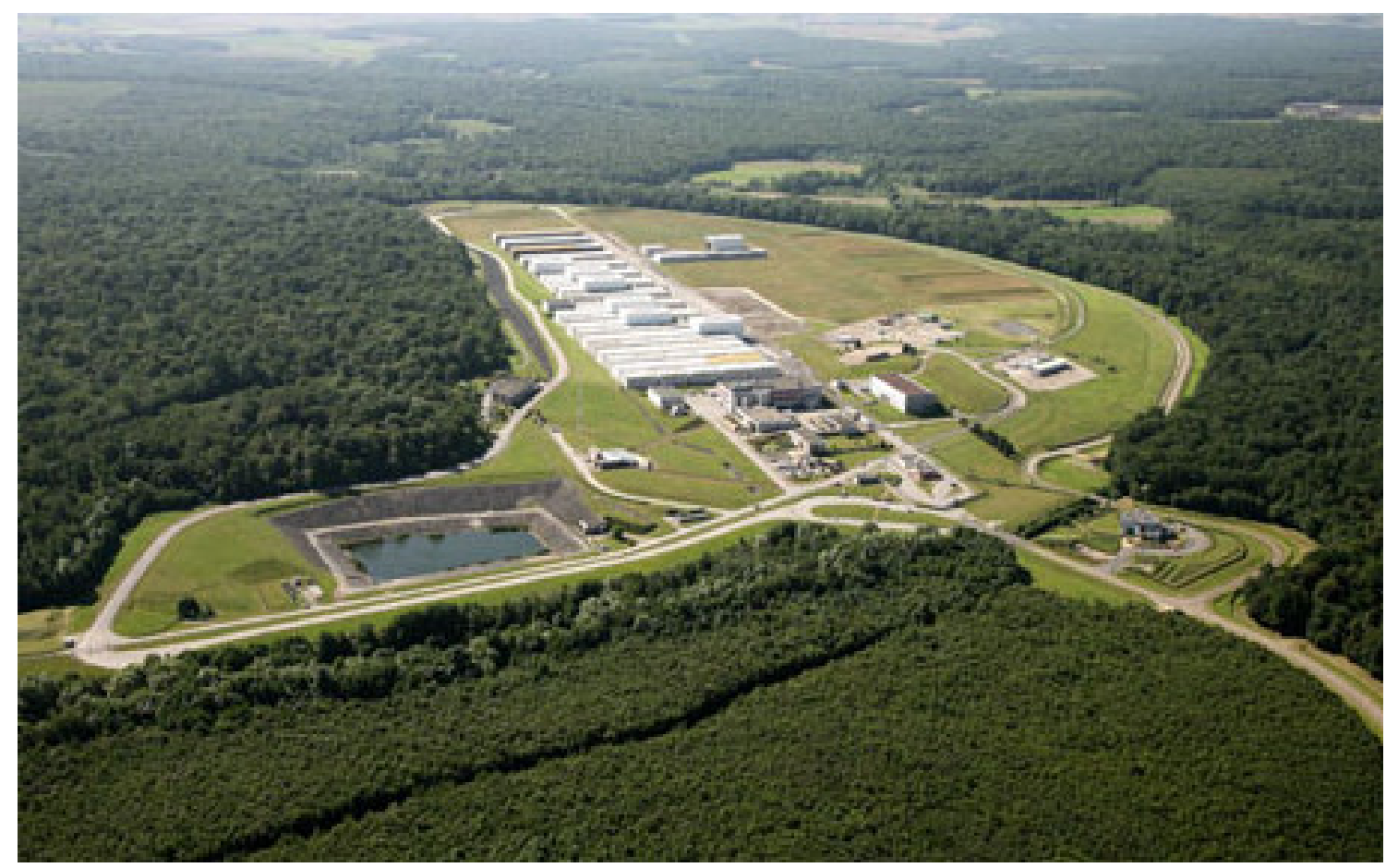

Figure 23. Centre de l'Aube LILW Repository (ANDRA 2011b)

concrete monoliths built on the host structures. The Centre de la Manche facility operated until July 1994. Between 1991 and 1997, ANDRA constructed and placed a cap that was designed to cover the disposal areas, isolate wastes from infiltrating water, and provide long-term protection against plant, animal, and human intrusion. In January 2003, the facility entered a post-closure monitoring and surveillance phase (for a maximum period of 300 years) to assess the operation of the cap and manage the safety of the facility (IAEA 2011a; Rep Fra 2008; IAEA 2001a; ANDRA 2011a).

The Centre de l'Aube Repository (CSFMA), pictured in Figure 23, is located in north-eastern France in Soulaines-Dhuys. The CSFMA was licensed in September 1989, became operational in January 1992, and took over a France's national LILW repository when the Centre de la Manche repository shut down. The site occupies about 95 acres (40 ha), with nearly a third used for disposal (ANDRA 2011b). Operating feedback from the Centre de la Manche was used to design this second French LILW repository. The CSFMA is authorized for $1,000,000 \mathrm{~m}^{3}$ total waste capacity (400 disposal structures) and contains facilities for waste disposal and conditioning.

Waste is deposited in engineered concrete disposal vaults, illustrated in Figure 24, that are divided by $8.5 \mathrm{~m}$ high internal concrete walls into a series of four or five cells designed to isolate the waste from groundwater and to have mechanical integrity for 300 years. These vaults are built as required and arranged in parallel rows over the disposal area. When a cell is ready for closure, it is backfilled, capped concrete slab, and a final multi-layer waterproof natural cover sloped to prevent stagnant water from collecting. Given an average annual waste delivery of between 10,000 to $15,000 \mathrm{~m}^{3}$, 92 disposal structures have been sealed from the facility commissioning in 1992, to the end of 2007. This volume of waste represents approximately 20 percent of the total authorized capacity of the repository (IAEA 2011a; Rep Fra 2008; IAEA 2001a; IAEA 2001b). 




Figure 25. Facility Layout for the CSTFA in France (ANDRA 2011b)

In addition, there is a dedicated facility for VLLW, the Centre de Morvilliers (CSTFA), located near the Centre de l'Aube around Troyes east of Paris. The CSTFA, pictured in Figure 25, has been in service since August 2003 and covers an area of more than 110 acres (45 ha), with nearly a two thirds used for disposal (ANDRA 2011b). This surface facility is licensed to hold $650,000 \mathrm{~m}^{3}$ of waste, primarily originating from nuclear facility decommissioning and dismantling, with average activity less than $10 \mathrm{~Bq} / \mathrm{g}$ (Voizard 2006). The CSTFA consists of four distinct areas: waste disposal area, earth storage area, storm basin, and industrial zone containing storage and conditioning buildings. A design cross section of a typical lined earthen disposal cell is illustrated in Figure 27, which utilizes removable buildings during the operational stage of disposal (as pictured in Figure 26). At the end of 2007, it had received over $89,000 \mathrm{~m}^{3}$ of waste intended for disposal, with an annual disposal rate of $25,000 \mathrm{~m}^{3}$. Close to 70 percent of this received waste (e.g., non-compactable rubble, metal scrap, etc.) was directed directly to the disposal area, after transiting through a storage building. The remaining 30 percent of the waste received was submitted to specific compaction and solidification treatments in dedicated areas before final disposal (IAEA 2011a; Rep Fra 2008).
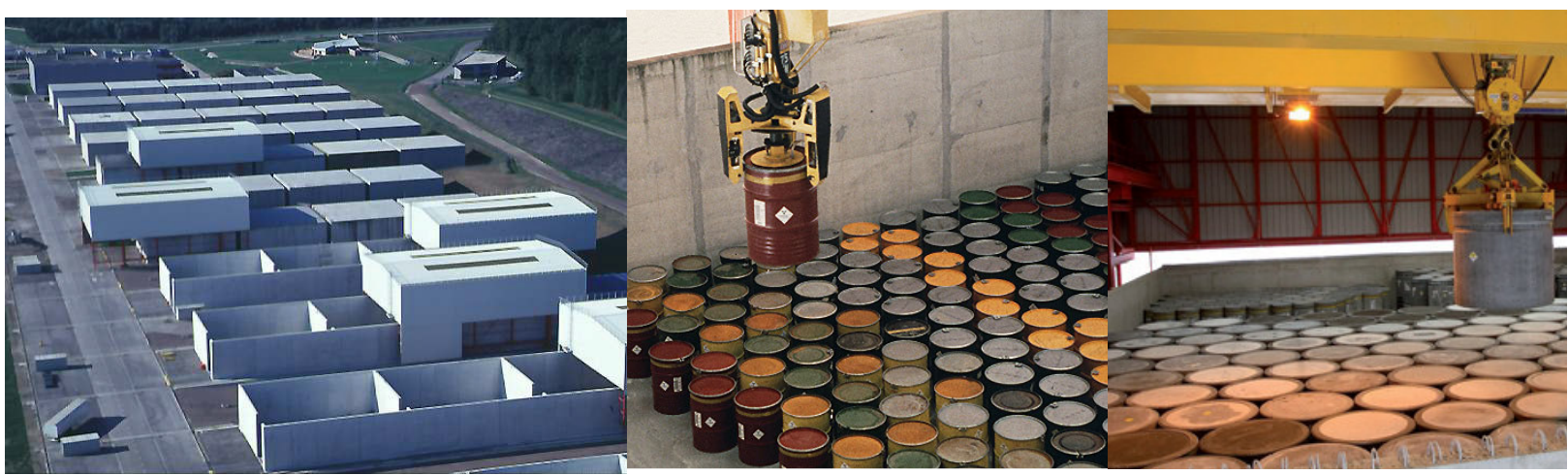

Figure 24. Concrete disposal vaults at the Centre de l'Aube LILW Repository (SE RAW 2011; ANDRA 2006, 2010) 


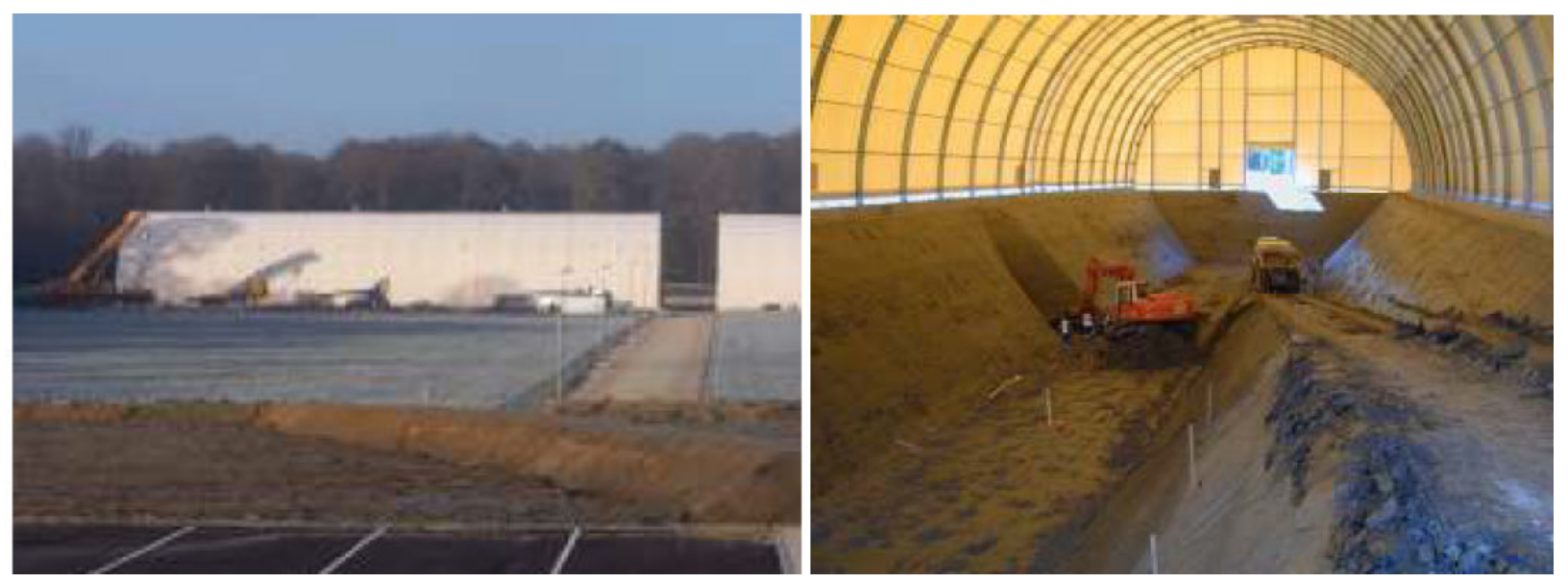

Figure 26. Removable Buildings used at the CSTFA (Voizard 2006)

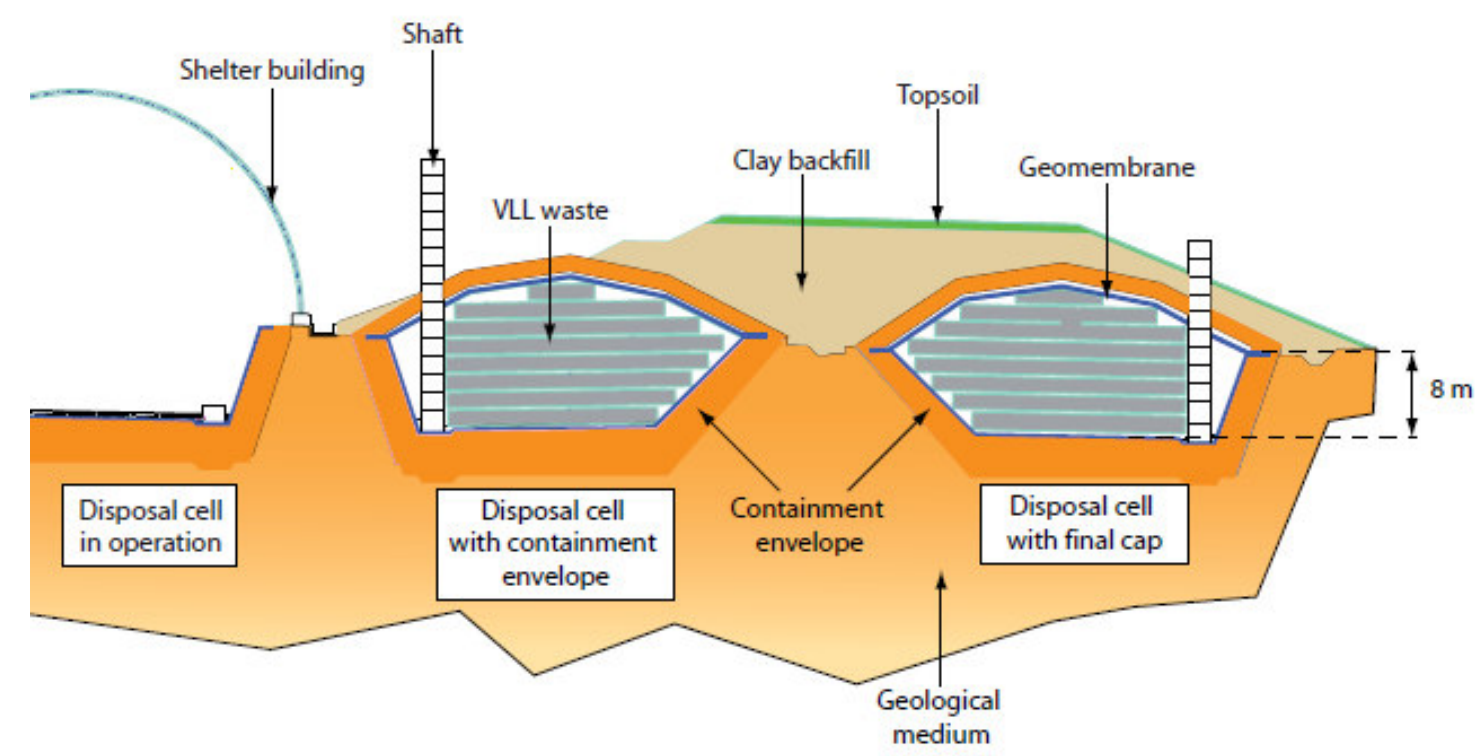

Figure 27. Cross Section of a VLLW Disposal Cell at the CSTFA (ANDRA 2008)

\section{Current and Future Initiatives}

For long-lived LLW, which includes waste containing radionuclides with half-lives over 30 years, a disposal center is under development with site selection and preliminary investigations are expected to be completed from 2008 to 2010, with operation planned for 2019. The final repository is likely to be a near-surface type constructed in clay, about $15 \mathrm{~m}$ below the land surface.

ANDRA also announced in August 2010 its intent to establish a commercially viable system to recycle materials recovered during decommissioning of nuclear facilities. Current French law prohibits using recycled materials from nuclear installations in non-nuclear applications, which not only discourages recycling of decommissioning waste but threatens to quickly fill ANDRA's Morvilliers disposal facility. Thus, the recycled materials, notably steel and concrete, would be used exclusively in the nuclear industry (WNA 2011k). 


\subsection{Germany}

\section{Nuclear Capabilities}

The nuclear power industry began in both West and East Germany, in the mid-1950's, with the assistance of the United States and Soviet Union, respectively. By the 1970s, after the first oil crisis, German support for nuclear energy was very strong in light of the perceived vulnerability regarding energy supplies. However, the last new NPP was commissioned more than 20 years ago (in 1989), as support faltered after the Chernobyl accident in 1986. At present, public opinion in Germany remains ambivalent and does not support building new nuclear plants.

Germany is currently working under a total nuclear phase out policy. Until March 2011, when the Chancellor decreed that the country's nuclear power reactors which began operation in 1980 or earlier should be immediately shut down, Germany had 17 operating nuclear power reactors, at twelve different sites, which accounted for approximately one quarter of total electricity. Currently, there are only 9 reactors remaining in operation at eight sites, in addition to twelve operational research reactors (WNA 2011I; IAEA 2009c). France, Poland, and Russia are expecting to increase electricity exports to Germany, mostly from nuclear sources, to meet Germany's energy demands (WNA 2011I).

\section{Regulation and Legislation}

In 2000, consensus talks between the German coalition government and electric utilities lead to an agreement for the eventual phasing out of nuclear power, which included limiting the operational lives of the reactors to an average of 32 years (WNA 2011I). According to a 2002 amendment to the country's 1959 Atomic Energy Act, each reactor has a fixed amount of megawatt hours that it is allowed to produce over its lifetime. When the reactor reaches its power limit, it has to be shut down permanently. Therefore, if this phase-out is not reversed, depending on their specific age and production history, all of Germany's reactors are expected to cease operating by 2023 (Sailer 2008).

As member state of the EU, OECD/NEA, and IAEA, Germany supports various international programs in nuclear safety and nuclear waste management. In 2007, the IAEA agency urged the German government to reconsider the policy in the light of adverse consequences, since it has been forecasted that, if Germany follows through with the nuclear phase-out policy, it will miss its carbon dioxide emission targets by a wide margin, face higher electricity prices, suffer more blackouts, and dramatically increase its dependence on foreign gas imports (particularly from Russia). The new coalition government elected in September 2009 is committed to rescinding the phase-out policy. After one year, a new agreement had been reached, to give 8year license extensions (from 2001-agreed dates) for reactors built before 1980, and 14-year extensions for later ones. These 2010 amendments to Germany's Atomic Energy Act, which are the core of national regulations with respect to nuclear safety and waste management in Germany, were confirmed by parliamentary vote in November 2010. However, in May 2011, after increasing pressure from anti-nuclear federal states, the German government decided to revive the previous phase-out plan. This will leave the eight oldest reactors closed (in March 2011), and result in the remaining nine closing by the end of 2022 (WNA 2011I; IAEA 2009c). 
The regulations laid down in the Atomic Energy Act are not exhaustive and are further specified by numerous ordinances, general administrative provisions, and non-legally binding regulatory guidance instruments. The Federal Office for Radiation Protection (BfS), founded in 1989 under the Federal Ministry for the Environment, Nature Conservation, and Nuclear Safety, is responsible for the management of radioactive waste, along with the design, construction, and operation of nuclear waste repositories. However, the BfS may employ the service of a third party, namely the German Company for the Construction and Operation of Waste Repositories (DBE, or Deutsche Gesellschaft zum Bau und Betrieb von Endlagern für Abfallstoffe mbH) specifically founded upon initiative of the Federal Government in 1979, to fulfill its tasks (BfS 2003; BMU 2008). The protection objective for disposal of radioactive waste in a repository is laid down in the Atomic Energy Act and the Radiation Protection Ordinance. The Federal Mining Act regulates the aspects concerning the operation of a disposal mine. The Safety Criteria for the Disposal of Radioactive Waste in a Mine specify the measures to be taken in order to achieve that this objective has been reached (IAEA 2009c). The cost of waste disposal, as all other waste management costs, is borne by the waste producers according to the polluter pays principle. To this aim, the Atomic Energy Act also includes two repository financing mechanisms ensuring sufficient funding is available as needed (Lempert and Biurrun1999; Sailer 2008).

Germany classifies radioactive waste into two waste categories (heat generating waste [HGW] and non-HGW), and six radiation protections groups based on activity limits, with further subdivision into solid, liquid, and sealed source (Lempert and Biurrun1999). In general, the nonHGW includes LLW and most ILW (as long as it is not heat generating) and is comparable to IAEA classification for LILW. Figure 28 provides a comparison of the German waste classification scheme with that defined by the IAEA (BMU 2008). Waste with very low radioactivity does not need to be specially handled if its radioactivity is below the clearance levels provided by German radiation protection ordinance and miscellaneous provisions. The

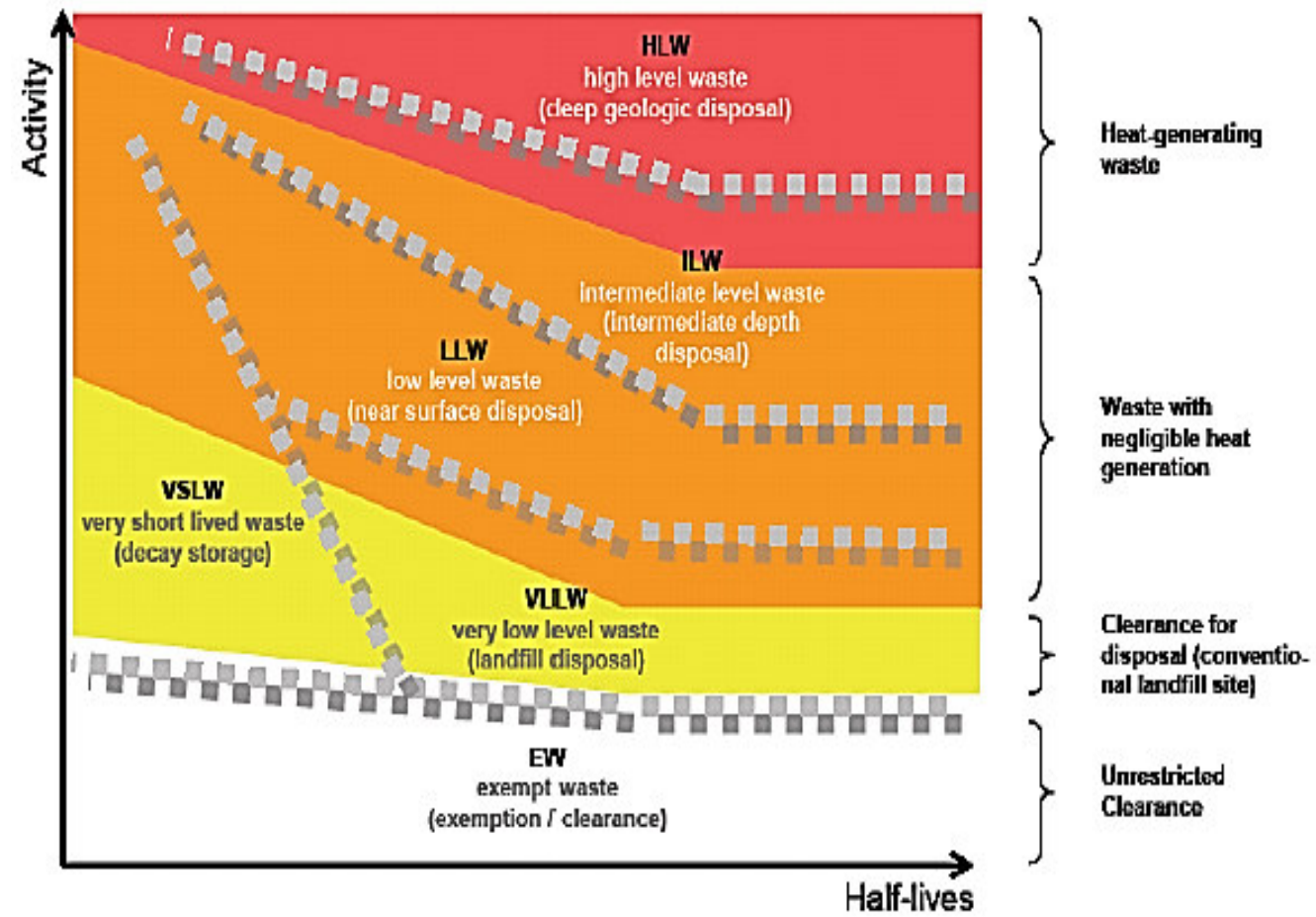

Figure 28. Comparison of German and IAEA waste classification schemes (BMU 2008) 
country doesn't differentiate between waste with long-lived isotopes and short-lived isotopes (Sailer 2008).

\section{Waste Management Practices and Facilities}

Germany does not have its own near surface disposal facility for reasons including the high population density and unfavorable climatic conditions. Thus, the disposal of all types of radioactive waste is intended to be in existing deep geological formations for a lifetime of 500 years, with the option to recover waste using the help of various mining techniques. Development work in this field started in the late 1960s (IAEA 2009c). There are currently two repositories in Germany storing LILW: Morsleben and Asse.

East Germany erected a repository at the former salt mine at the Morsleben site, which operated for about 70 years until 1969, leaving approximately 8 million $\mathrm{m}^{3}$ of open cavities (DEB 2011; Lempert and Biurrun1999). The Morsleben Repository for Radioactive Waste (ERAM) was licensed for disposal of LILW in 1981, and then re-licensed post reunification in 1990, and took in waste from nuclear power plants as well as waste from research, medical, and industrial applications (BMU 2008). The facility had a depth of depth of 400 to $600 \mathrm{~m}$ deep. In this worldwide pioneer deep geologic repository, approximately $37,000 \mathrm{~m}^{3}$ of waste, stacked in $200-$, 280-, 400-, and 570-L drums and concrete containers in underground chambers (as pictured in Figure 29), was emplaced until 1998, when the facility closed. The installation, which is considered to be in poor condition due to rock and mechanical instabilities caused by extensive mining activities and a high excavation ratio in the central section of the mine, is now being decommissioned and stabilized with an estimated $740,000 \mathrm{~m}^{3}$ of special-purpose concrete (IAEA 2009c; DBE 2011; WNA 2011I; Brewitz and Rothfuchs 2007).
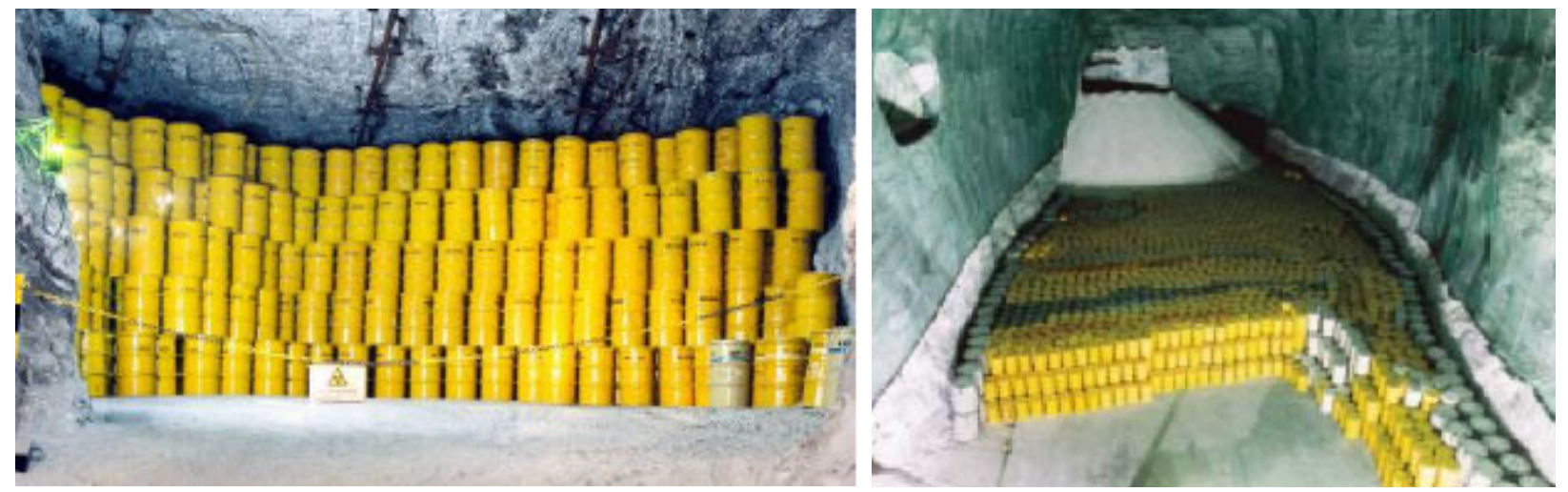

Figure 29. Stacked LLW drums at the Morsleben LILW Repository (Brewitz and Rothfuchs 2007)

West Germany operated the Asse research mine, which is a 100-yr old potash mine and salt dome in Lower Saxony, where the Helmholtz Zentrum München carried out fundamental research on radioactive waste disposal in salt rock from 1965 to 1992 . The Asse mine was licensed as a repository for LILW disposal by federal and state agencies from 1967 until 1978. During this time, workers stored drums of LILW (90 percent of which originated from nuclear power plants) inside former mine chambers as deep as $750 \mathrm{~m}$ (as pictured in Figure 30). After 1978, further emplacement was halted, although research and development on the safe disposal of radioactive waste was performed until 1992. In the beginning of 2009, responsibility for the operation of the Asse mine was transferred from Helmholtz Zentrum München to the 
Federal Office for Radiation Protection (BfS) (IAEA 2009, CNNP Ger; WNA 2011; Owen 2010; IAEA 2011a; Brewitz and Rothfuchs 2007).

The Asse repository is now closed and is considered to represent a failure of the German licensing process (WNA 2011l). Since its closing, rock instabilities caused by extensive past mining activities have led to problems of mechanical stability, similar to those at ERAM, resulting in water seepage into the mine and dissolution of the rock salt. Authorities fear that



Figure 30. Salt-lined chamber at the Asse Research Mine (Schwarz 2010) groundwater in the region could become contaminated with radioactive waste, and are currently pumping some 3,170 gallons $(12,000 \mathrm{~L})$ of salt-saturated water a day from the mine to stop it from coming into contact with the nuclear waste. As a result, the BfS decided in 2010 to move the more than 120,000 containers of LLW (packed in 200- or 400-L drums or concrete shields) and about 1,300 containers of ILW (in 200-L drums) stored there, rejecting the alternative of filling the mine with concrete to provide a stable matrix (WNA 2011l; Owen 2010). However, poor recordkeeping regarding exactly what is in many of the barrels and the previous practice of disorganized dumping into jumbled piles (as illustrated by the 1970s photographs in Figure 31), poses numerous challenges and potential hazards for the waste removal teams. If removal is successful, the Konrad site (described below) will likely be the final destination for the relocated LILW (WNA 2011I).
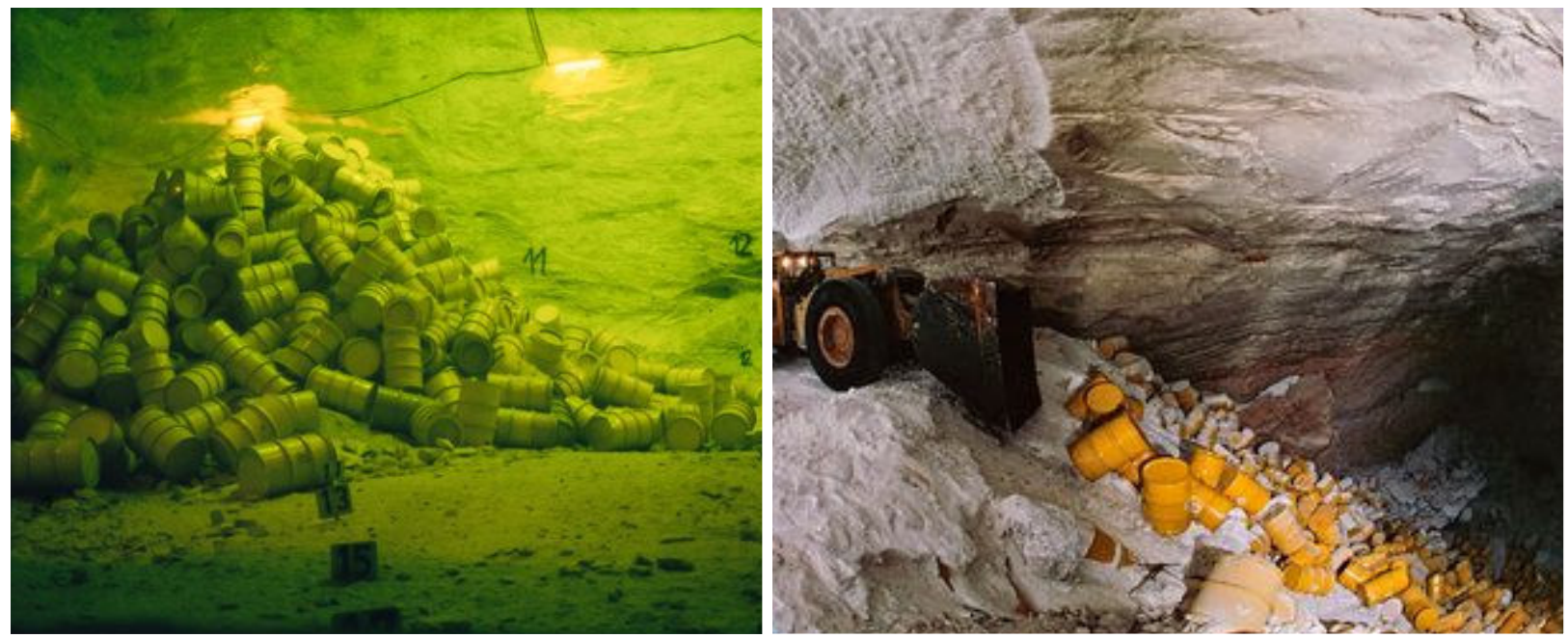

Figure 31. Disorganized piles of nuclear waste lie untouched since their disposal (Kristof 2010) 


\section{Current and Future Initiatives}

The salt dome at the Gorleben site, whose top is about $250 \mathrm{~m}$ below the surface and base is located at a depth of between 3,200 and 3,400 m, was initially assessed in 1979 for its suitability as repository for all types of radioactive waste (including HLW). The above ground portion of the site covers an area of nearly 70 acres (28 ha) with a planned total underground storage capacity of around $400,000 \mathrm{~m}^{3}$. Underground exploration work started in 1985, and several levels, ranging from 820 to $930 \mathrm{~m}$, have been excavated in the exploration mine. In total, about $7 \mathrm{~km}$ of drifts and galleries with a volume of approximately $234,000 \mathrm{~m}^{3}$ and about $16,000 \mathrm{~m}$ of boreholes had been drilled and excavated by October 2000, when exploration was suspended. Work was interrupted as part of the nuclear phase out agreement for a span of up to ten years, pending further study with respect to the suitability of salt as host rock in general and of the Gorleben site in particular. Currently, the geological findings do not contradict the suitability of the site as a repository; however a definitive statement can only be made following further examination of alternative sites with favorable geological settings and conclusion of safety analyses (IAEA 2009, CNNP Ger; WNA 2011w; IAEA 2011a; BMU 2008). Ongoing work at Gorleben is essentially limited to service and maintenance activities, as well as the survey and documentation work, that is necessary and useful to sustain the mine during the moratorium period as not to render the previous investment and exploration work meaningless (DBE 2011).

A fourth LILW repository site, located at the former Konrad iron ore mine in Salzgitter, has been under development since 1975. After almost 20 years of proceedings, which qualifies as the longest public hearing process in the history of German administrative law, the plan to convert the Konrad mine and to operate it as a final repository for disposal of non-HGW was approved in May 2002. It was not until 2007, after 5 years battling legal challenges and appeals against the licensing decision, which were all eventually dismissed, that the BfS founded a working group responsible for planning the conversion of the mine into a safe repository. A construction license was issued in January 2008 and the Konrad repository is expected to be operational between 2013 and 2014. The encasement drifts and waste disposal areas, which could then be backfilled and sealed, are to be located at depths between 800 and 1,300 m (Sailer 2008; Borrmann et al. 2007). The rock layers surrounding the waste drifts are mainly sandstone underneath clayey sediments. Konrad will initially take some $300,000 \mathrm{~m}^{3}$ of wastes, which accounts for about 90 percent of the country's waste volume, with $1 \%$ of the radioactivity. However, DBE plans indicate a total design capacity for $650,000 \mathrm{~m}^{3}$ of wastes. In the conditions for acceptance of non-HGW issued by the federal agency for radiation protection, the allowed waste packages are specified as waste 200 - and 400-L drums and containers with those waste drums inside. The conditions also include specifications for the content of radionuclides and the chemical and mechanical form of the waste. Before delivery to the final disposal facility, the waste must adhere to these conditions and be verified by the federal agency for radiation protection, which a majority of the country's existing non-heat-generating waste already does (IAEA 2009, CNNP Ger; DBE 2011; WNA 2011l; BMU 2008).

\subsection{India}

\section{Nuclear Capabilities}

Electricity demand in India is increasing rapidly, with 2008 production numbers triple the nation's 1990 output. Thus, there is good acceptance of nuclear power that has resulted in a flourishing and largely indigenous nuclear power program, which aims to supply $25 \%$ of the country's 
electricity from nuclear power by 2050 . There are currently 20 nuclear power reactors operating and producing only about three percent of the country's electricity. However, six additional units are under various stages of construction (WNA 2011m).

Because India is outside the 1970 Nuclear Non-Proliferation Treaty, due to its weapons program, it was essentially excluded for decades from trade in nuclear plant or materials, which has hampered its development of civil nuclear energy until 2009. As a result, India's nuclear power program has proceeded largely without fuel and technological assistance from other countries, which has led to the unique development of a nuclear fuel cycle to exploit its reserves of thorium. In addition, this has resulted in the necessity of India to operate waste management facilities covering the entire nuclear fuel cycle. Since 2009, foreign technology and fuel have boosted India's nuclear power plans considerably. To date, some 300 reactor-years of operation had been achieved (WNA 2011m; Kumar et al. 1999).

\section{Regulation and Legislation}

The Atomic Energy Commission (AEC) was established in 1948 under the Atomic Energy Act as a policy body. Then in 1954, the Department of Atomic Energy (DAE) was set up to encompass research, technology development, and commercial reactor operation. The current Atomic Energy Act (1962) is the main law governing the nuclear industry and permits only government-owned enterprises to be involved in nuclear power. The Atomic Energy Regulatory Board (AERB) was formed by the Government in 1983 to carry out regulatory and safety functions as envisaged in the Act. The Atomic Energy (Safe Disposal of Radioactive Wastes) Rules, issued under the main Act in 1987, establishes the requirements for the disposal of radioactive waste arising out of operation of NPP in the country (India 2007). In addition, management of radioactive wastes is carried out in conformity with the guidelines specified by the Regulatory Authorities based on internationally accepted principles in line with the guidelines laid down by the international agencies (WNA 2011m; Munshi 2007). For management purposes, India classifies its wastes into four categories: potentially active waste (PAW, similar to VLLW), LLW, ILW, and HLW (Ramana et al. 2001).

The safe management of radioactive waste, including its disposal, has been given utmost importance right from the inception of India's nuclear power program. All nuclear power plant sites in India are self-sufficient in the management of radioactive waste generated there. Adequate facilities have been provided for handling, treatment and disposal of wastes generated from plant operation at these sites. This has helped national acceptance of governmental policies by the public at large (India 2007; Munshi 2007).

\section{Waste Management Practices and Facilities}

Considering the vastness of India and the fact that nuclear reactors are located all over the country, the logistics for the safe transportation of radioactive waste dictates that the Near Surface Disposal Facilities (NSDFs) for the disposal of LILW are co-located with the NPP complex in the $1.6 \mathrm{~km}$ radius exclusion zone from the reactor building. Thus, the concern for acquisition of additional land for repositories is addressed along with the reactors siting requirements (Munshi 2007; IAEA 2001a; India 2010).

Currently there are seven operating NSDFs for LILW in India co-located with power/research reactors: Trombay, Maharashtra (1956); Tarapur, Maharashtra (1969); Kota, Rajasthan (1972); Kalpakkam, Tamil Nadu (1984); Narora, Uttar Pradesh (1989); Kakrapar, Gujrat (1993); and Kaiga, Karnataka (2000). All of these facilities designed and constructed to address widely 
varying geological and climatic conditions. In general, each of these NSDFs is sub-divided into zones for the various types of waste disposal and employs the multiple barrier approach. Disposal cells typical for an Indian LILW facility include stone-lined earth trenches, reinforced concrete trenches/vaults, and steel lined concrete tile holes (Munshi 2007; India 2007; Raj et al. 2006; IAEA 2001a; IAEA 2001b).

The earth trenches are mainly used for LLW. They are typically excavations that are 1 to $4 \mathrm{~m}$ deep and provided with stone lining for stability and integrity. On completion of the disposal, the void space is backfilled with a mix of vermiculite, bentonite and native soil (with good sorption properties) and closed with a one meter thick soil cover.

Reinforced concrete vaults are modular in construction and planned in a zone-wise manner. A typical trench is generally about $5 \mathrm{~m}$ deep, 2.5 $\mathrm{m}$ wide, and $15 \mathrm{~m}$ long with an outer containment wall varying from 0.35 to $0.75 \mathrm{~m}$, as depicted in Figure 32. Due to special considerations, such as seismicity at Narora and less soil coverage at the Kota site, the trenches may be constructed totally or partially above ground (Kumar et al. 1999). Each zone of trenches is serviced by either a gantry or a mobile crane. All outer surfaces are given waterproofing treatment to prevent ingress of groundwater and partially filled trenches are protected using mobile covers. After the vaults are filled, pre-cast concrete slabs are placed on top to provide necessary shielding. Over these top slabs, a RCC is added and given a necessary



Figure 32. Typical schematic diagram of reinforced concrete trench at a NSDF in India (Raj et al. 2006) slope to facilitate self-drainage. The placement of the RCC is followed by a polythene sheet, rich cement mortar, broken brick rubble, and finally a water repellent cement plaster.

Tile holes designed and constructed for disposal of ILW waste (classified as containing more than $4000 \mathrm{~Bq} / \mathrm{g}$ of alpha activity), which has activity higher than permissible for reinforced

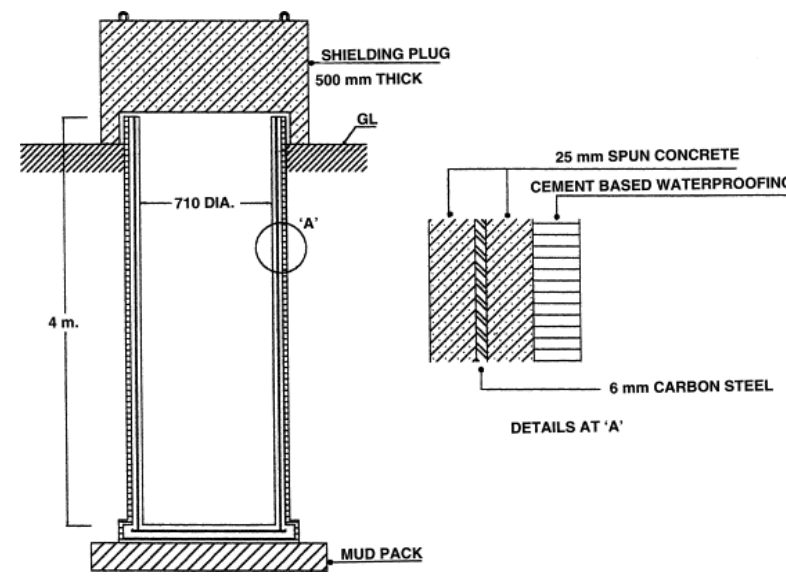

Figure 33. Typical construction details of tile hole and shielding plug at a NSDF in India (Raj et al. 2006) concrete trenches. In general, conditioned waste is packaged in standard 200-L drums and retrievably stored in these tile holes. These circular vaults are nearly $4 \mathrm{~m}$ below ground level with an average inside diameter of about $0.7 \mathrm{~m}$. Each tile hole has a carbon steel shell, with one end closed, covered inside and out with a cement mortar applied over reinforcing mesh. Typical construction details are given in Figure 33. At closure, cement, non-reactive aggregates, and inert fillers, like garnet and granite sand, are used to fill voids and facilitate the sealing and placement of precast concrete plugs that provide the necessary shielding. Additional protection with waterproofing is done on the outer surface, thus sealing the joints and open ends. 
To provide necessary biological shielding and working space around the disposal facilities, earthen embankments with stone pitching are provided on all sides of the facilities. Apart from continuous monitoring and surveillance of these repositories, a buffer zone is kept between disposal facilities and repository boundary to delay the migration of radionuclides. In addition, due care is taken to address the basic socioeconomic and public acceptance aspects related to these facilities (Munshi 2007; Raj et al. 2006; IAEA 2001a; IAEA 2001b).

\subsection{Japan}

\section{Nuclear Capabilities}

Japan depends on fossil fuel imports for approximately 80 percent of its primary energy needs, primarily due to the fact that it has few natural resources of its own and as an island nation it is not possible for Japan to exchange energy with neighboring countries through power transmission lines or pipelines (FEPC 2002). The Japanese energy policy has developed a major nuclear program as one of the mainstays of the nation's energy supply. Japan's first commercial nuclear power plant began operation in Ibaraki Prefecture in 1966. Before March 11, 2011 earthquake, there were 54 power reactors in operation (with 1 in long-term shutdown), 2 additional power units under construction, and 15 functioning research reactors. According to the Japan's existing energy policy nuclear power reactors accounted for nearly 30 percent of the domestic electricity production and there were plans to increase this figure to just over 40 percent by 2017, and 50 percent by 2030 (WNA 2011n; Japan 2008; FEPC 2002).

Because of limited natural resources, the country also has a policy of reprocessing in which the spent nuclear fuel is reprocessed to recover unused uranium and plutonium. Currently, a small reprocessing plant is operating at Tokai Mura and a large reprocessing complex at RokkashoMura in Aomori Prefecture is under construction (the operation is expected to start in 2012).

After the March 11, earthquake followed by $42 \mathrm{ft}$ high tsunami, four units (units 1-4) of Fukushima Daiichi plants are seriously damaged. After this nuclear crisis, Japan's energy policy is currently under 12-month government review. In mid May 2011, only 17 nuclear power reactors were operating, 20 units were shut for periodic inspection, 2 units were shut for unplanned inspection or equipment replacement, 2 units were shutdown to increase their resistance to tsunami, 9 units were shutdown during the earthquake.

\section{Regulation and Legislation}

The Japanese Agency with responsibility for radioactive waste management policy is the Ministry of Economy, Trade, and Industry (METI). The treatment, storage, and disposal of radioactive waste generated during operation of nuclear facilities are regulated by either the Law for Regulation of Nuclear Source Material, Law for Nuclear Fuel Material and Reactor Regulation, or Law for Prevention of Radiation Hazard due to Radioisotopes (according to the kind of facilities which generate the wastes). Basically, these laws state that radioactive wastes generated at nuclear facilities are the responsibility of the generator and are to be safely managed at the individual sites, prior to final disposal (FNCA 2007; FEPC 2002). Ultimately, Japanese waste policy is defined in the Specified Radioactive Waste Final Disposal Act (2000), which mainly prescribes methods for final radioactive waste disposal, a funding mechanism for securing disposal costs (Radioactive Waste Management Funding and Research Center 
[RWMC]), and a site selection process to be carried out by the Nuclear Waste Management Organization (NUMO) of Japan (WNA 2011n).

\section{Waste Management Practices and Facilities}

In Japan, LLW typically refers to all radioactive waste other than HLW (which includes liquid and vitrified waste from spent fuel reprocessing). The Japanese Nuclear Safety Commission (JNSC) issued a document in May 2007, which provides for upper bounds of concentration of radioactive elements in waste packages. The upper bounds are so decided, that the public exposure due to waste packages is well within the reference value are in conformity with the latest knowledge in the international community. Thus, the disposal of radioactive waste is categorized into two categories: Category 1 - geological disposal, and Category 2 intermediate waste disposal, near surface disposal with artificial barrier, and near surface disposal without artificial barrier (Japan 2008).

Category 2 LLW is further classified based on origin. The LLW from Japan's nuclear power reactors is placed in $200-\mathrm{L}$ drums after treatment (e.g., concentration and solidification for liquids; incineration and compaction for solids) and temporarily stored in specifically designed on-site storage facilities (see Figure 34) while they await final disposal. Low-level uranium waste produced via the fuel cycle is placed into drums and also stored at on-site depositories. Radioactive waste generated from non-nuclear power related facilities (e.g., medical, industrial, and research) that use radioisotopes and radiation generating apparatus is collected by the license holders of the waste management business, who store it at their own depositories after compaction or incineration. Finally, radioactive waste generated in the facilities of research reactor and fuel

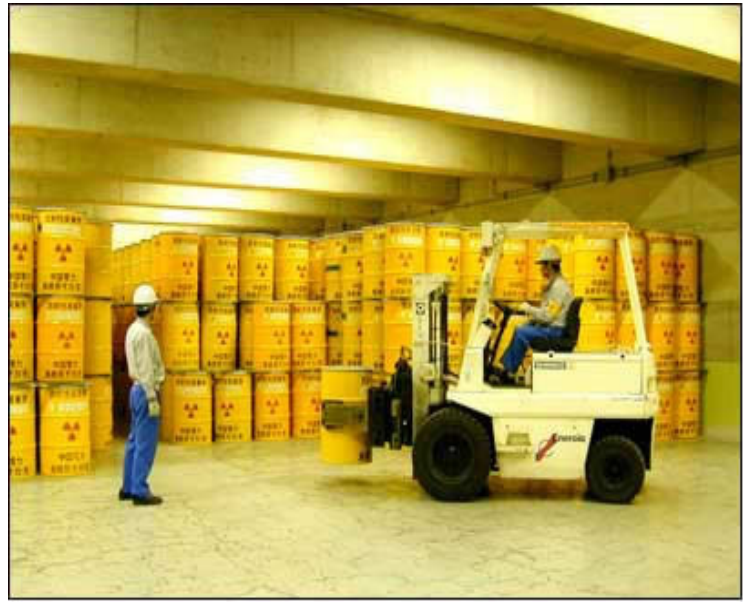

Figure 34. Workers at a nuclear plant disposing of LLW drums in Japan (FEPC 2002) material use of the Japan Atomic Energy Agency (JAEA) and universities are stored at their own depositories after compaction or incineration (Japan 2008). 

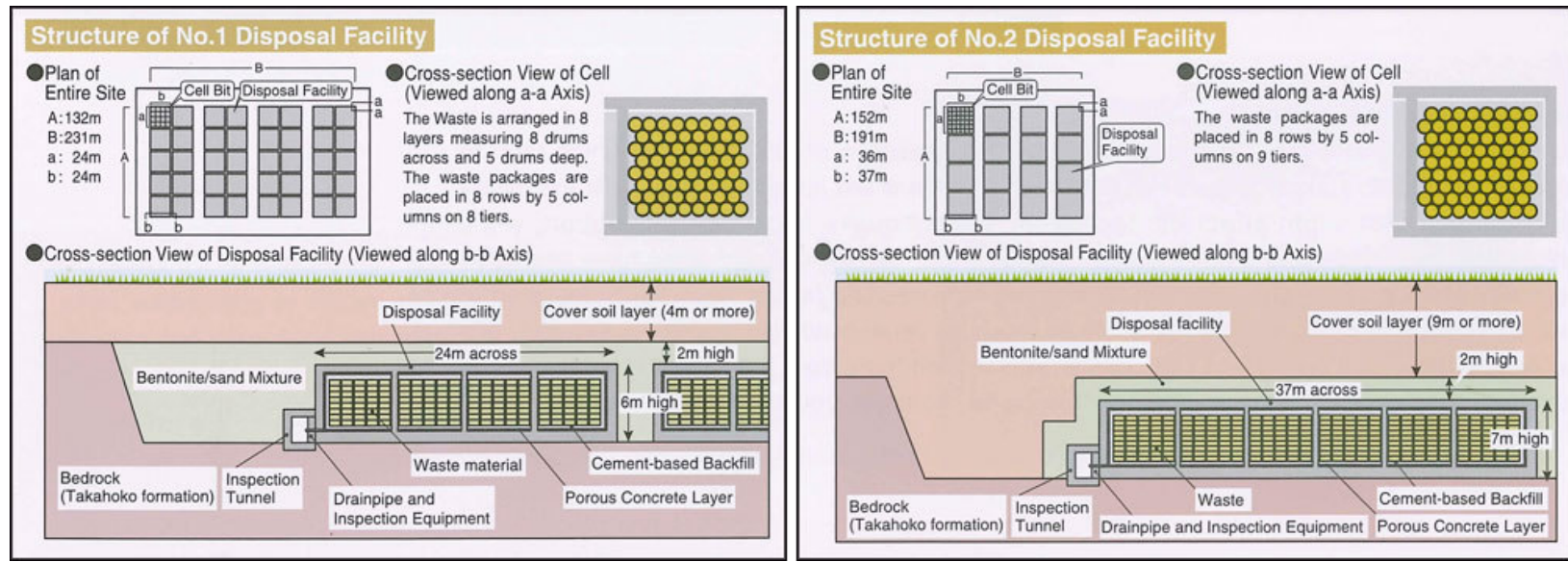

Figure 35: JNPL LLW Disposal Facility Structures (JNPL 2011)

The principal LLW disposal center for Japan, located in Rokkasho Village of Aomori Prefecture (see Figure 37), has been operational since 1992. This disposal center is part of the Japan Nuclear Fuel Limited (JNFL) nuclear fuel cycle facilities. JNFL is a private venture led by ten domestic electric power companies. Following on-site storage, LLW is shipped to this site from individual nuclear power plants throughout the country. The majority of the waste consists of liquid waste concentrates, spent resins, waste sludge, and other operational wastes placed in 200-L metal drums. The LLW disposal center is comprised of two licensed near-surface facilities with a total authorized capacity of about $80,000 \mathrm{~m}^{3}$ (equivalent to 400,000 waste drums), with the final total design capacity of $600,000 \mathrm{~m}^{3}$ (JNFL 2011; Thomson 2009; Sumi and Matsuo 2005). The facilities were constructed on top of bedrock below the water table and their basic structures are illustrated in Figure 35. The waste is disposed of in engineered concrete pits (white, square buildings in Figure 37, which measure $24 \mathrm{~m} \times 24 \mathrm{~m} \times 6 \mathrm{~m}$, that pit can hold up to 5,000 drums. Each pit is divided by bulkheads into 16 different cells where the drums are stacked using a specially designed burial crane (pictured in Figure 36). When closed, the empty space between the drums is backfilled with cement mortar and topped with a reinforced concrete lid. In order to further seal in the radioactive materials, the top and sides of the facility are covered by a $4 \mathrm{~m}$ thick mixture of water-impervious soil and bentonite (a kind of clay) topped with grass and trees (Japan 2008;

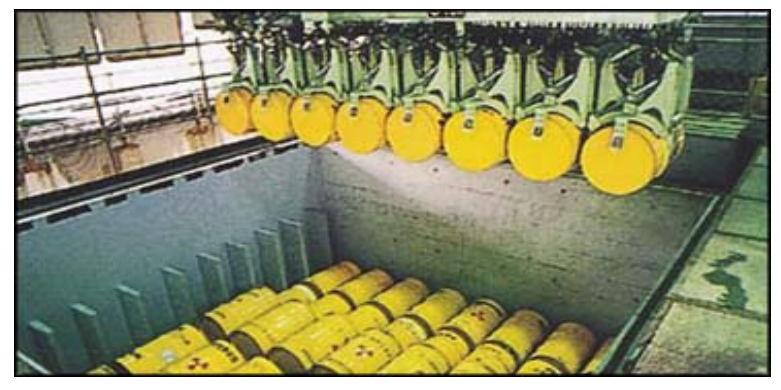

Figure 36: Waste packages are stacked inside disposal facility by crane (JNFL 2011)

JNFL 2011). As of March 2011, the JNFL LLW disposal facility has disposed of more than 230,000 steel drums of waste, as of the end of March 2008 . In addition, there are currently plans to construct a sub-surface disposal facility, at around a 50 to $100 \mathrm{~m}$ depth, for ILW (referred to as "relatively higher level LLW") and geological investigations were completed in March 2006 (JNFL 2011; Sumi and Matsuo 2005). 
Waste is also treated and stored at facilities operated by the JAEA, which is engaged in research and development on new types of power reactors and nuclear fuel cycle technology. The disposal facility is located at the Tokai Research and Development Center, Nuclear Science Research Institute of JAEA and utilizes shallow trench disposal for its VLLW (FNCA 2007). It started operation in 1995, with a design capacity equivalent to approximately 140,000 drums (nearly $28,000 \mathrm{~m}^{3}$ ), but has been at the preservation stage since October 1997 . Currently, nearly 1,700 tons of VLLW are stored here, with the majority resulting from the dismantling of the Japan Atomic Energy Agency (JPDR) demonstration reactor (Japan 2008).

\subsection{Korea (Republic of)}

\section{Nuclear Capabilities}

Nuclear energy is a strategic priority for the Republic of Korea (commonly referred to as South Korea). Commercial utilization of nuclear power began in 1978. Currently about one quarter of Korea's electricity needs are provided by its 21 reactors located at four nuclear power complexes. With 5 additional reactors currently under construction and 14 total new reactors projected to be online by 2024 , Korea has plans to increase the portion of electricity generated from nuclear power to more than 50 percent by 2020, and then to nearly than 60 percent by 2030 (WNA 2011p; NTI 2011b; FNCA 2007).

\section{Regulation and Legislation}

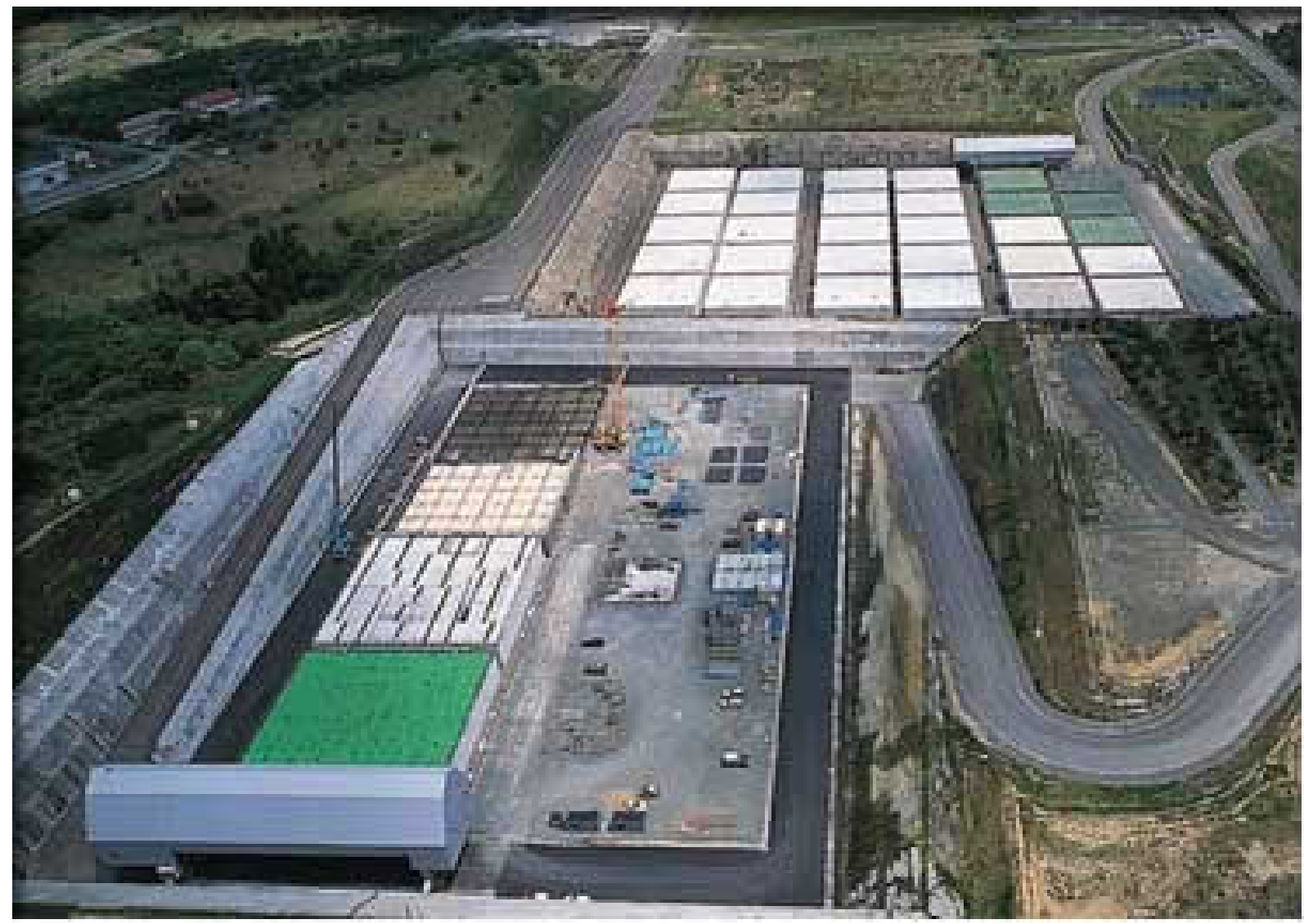

Figure 37. LLW Disposal Center at the JNFL site in Rokkasho (FEPC 2002) 
The Korean Atomic Energy Commission (AEC) is the highest policy-making body on nuclear matters, with the Prime Minister as chairperson. The Ministry of Education, Science, and Technology (MEST) is the authority of Korean Government that is responsible for establishing and implementing nuclear regulatory policies for the control of nuclear activities and applications. The Atomic Energy Act (1958) is the basic law for utilization and safety regulation of atomic energy. This Act has been amended several times, the one such amendment in 1986 provided the legal basis for the establishment of radioactive waste management fund by establishing a polluter pays principle, which levied a fee based on power generated. The fees were collected by the MEST and paid into a national Nuclear Waste Management Fund. In addition, several kinds of technical standards and criteria for radioactive waste management practices have been promulgated by MEST as Notices, including performance, general waste acceptance, siting, design features and quality assurance criteria for the repository and interim storage facility (FNCA 2007). In 1996, the Nuclear Environment Technology Institute (NETEC) was created as a dedicated agency responsible for radioactive waste management. A revised waste program was drawn up by NETEC and approved by the Atomic Energy Commission in 1998. The fundamental principles of the new national policy includes management under direct government control, minimization of waste generation, top priority for safety, reiteration of pollution pays principle, and transparency of the repository site selection process (OECD-NEA 2005; OECD-NEA 2010e)

In Korea, radioactive wastes are categorized into only two types. HLW is comprised of spent fuels, since Korea does not have any reprocessing plans, and the remainder of the radioactive waste produced falls into the category of LILW (FNCA 2007; OECD-NEA 2010e).

\section{Waste Management Practices and Facilities}

At the early stage of nuclear power development in Korea, radioactive waste management practice involved reduction of the waste volume by conditioning (e.g., evaporation, compaction, cementation, etc.) and storage within the nuclear facility site boundary. The final disposal facilities were to be considered and constructed at a later date; however, such facilities did not become operational until December of 2010 . Thus, there is currently about $12,000 \mathrm{~m}^{3}$ of treated nuclear power related LILW being temporarily stored in 200-L drums at the nuclear reactor sites. In addition, radioisotope related waste resulting from various medical, industrial, educational, and research applications is collected and stored at the NETEC, under the proprietorship of Korea Hydro and Nuclear Power Company, Ltd. (KHNP), separate from the NPP operational wastes. As the waste continues to pile up and interim storage facilities get closer to reaching their capacity, the necessity for a final disposal site continues to increase (WNA 2011p; FNCA 2007; OECD-NEA 2005; Park 1999). The Korea Radioactive Waste Management Co Ltd (KRWM) was set up early in 2009 as an umbrella organization to resolve Korea's waste management and disposition issues (WNA 2011p).

\section{Current and Future Initiatives}

For the past few decades, a great deal of effort has been exerted to secure a candidate site for the nation's central LILW repository. The Korea Atomic Energy Research Institute (KAERI) and MEST had responsibility for initial site selection from 1986 to 1996 . After five unsuccessful attempts, the NETEC took over the task of finding suitable repository sites. In 2000, the NETEC initiated an open solicitation to local communities calling for volunteers to host a disposal facility. Even though seven stepped forward, all local governments vetoed the proposal in 2001. Subsequently in 2003, the Ministry of Commerce, Industry, and Energy (now the Ministry of 
Knowledge Economy - MKE) then selected four sites for detailed consideration and preliminary environmental review, with an aim to negotiating acceptance with local governments. A Site Review Committee comprised of members of government, research institutes, nongovernmental social groups, and universities are to make the final selection. The area ultimately selected for the LILW facility will get 300 million won (about $\$ 260$ million US) in community support according to The Act for Promoting the Radioactive Waste Management Project and Financial Support for the Local Community (2000). The aim of this is to compensate for the psychological burden on residents, to reward a community (within a $5 \mathrm{~km}$ radius of the facility) participating in an important national project, and to facilitate amicable implementation of radioactive waste management. In November 2005, in the tenth attempt at site selection and after votes in four provincial cities, Gyeongju was designated as the site for the nation's first LILW repository (with nearly 90\% voter approval). In June 2006, the Korean Government officially announced that the municipality of Gyeongju, located on the east coast of Korea about $370 \mathrm{~km}$ southeast from Seoul, would be the site of Korea's first LILW repository (WNA 2011p; Korea 2008; FNCA 2007; IAEA 2009d; OECD-NEA 2005).

The Wolsong LILW Disposal Center, depicted in Figure 38, covers approximately 520 acres (210 ha) bounded by a national park to the north and the Wolsong NPP to the south (Park et al. 2009). The design will involve shallow geological disposal in a stable and homogeneous granite rock formation using engineered rock caverns (silos) built approximately 80 to $130 \mathrm{~m}$ below the



Figure 38. Wolsong LILW Disposal Center site in Gyeongju (Kim 2010)

surface. The disposal facility will initially consists of six silos reinforced with shotcrete and a concrete lining, each with a capacity of approximately 16,000 drums, and is initially licensed to dispose of 100,000 waste packages (200-L drums, totaling approximately $20,000 \mathrm{~m}^{3}$ ), but has a conceptualized design capacity of 800,000 packages. Most waste storage containers will be packed using disposal concrete containers that are then disposed of in the disposal silos. In 
addition to the disposal silos, the underground facilities include a construction tunnel, an operation tunnel, vertical entrances, and an unloading tunnel for construction and operation. A conceptual drawing of the post-closure disposal silo is presented in Figure 39. The Wolsong facility has been approved simultaneously for operation and construction. Construction started in April 2008 and operation commenced in December 2010, accepting its first 1000 drums of wastes there from the Ulchin NPP. These waste drums will be held in outdoor storage until the underground repository itself is finally commissioned in 2012. An estimated nine such shipments are expected annually (WNA 2011p; IAEA 2009; Korea 2008; CNPP RoK; FNCA 2007; Kim et al. 2007; OECD-NEA 2005).
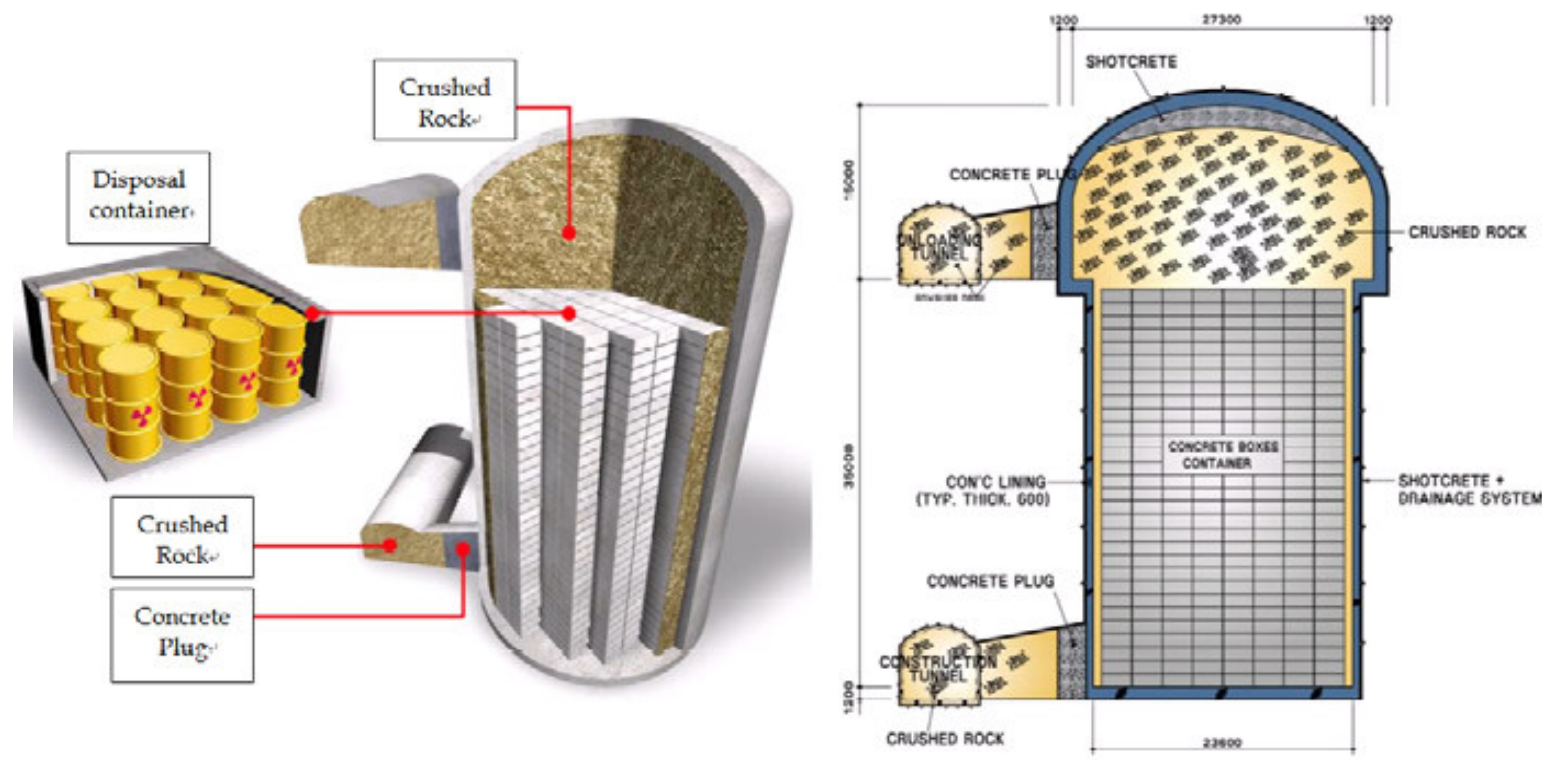

Figure 39. Conceptual drawing of the post-closure disposal silo (Kim 2010)

\subsection{Russia}

\section{Nuclear Facilities}

The Russia Federation's first nuclear power plant, Obninsk built in 1954 in the former Union of Soviet Socialist Republics (USSR or Soviet Union), was the first reactor in the world to produce electricity. By the mid-1980s, 25 power reactors were in operation within the Soviet Union, but the nuclear power industry was beset by problems. During the decade following the Chernobyl accident in the Ukraine and breakdown of the Soviet Union (1986 through the mid-1990s), Russia was focused on resolving its nuclear issues and, as a result, only commissioned 5 new reactor units. After the collapse of the Union of Soviet Socialist Republics (USSR or Soviet Union), economic reforms meant an acute shortage of funds for nuclear developments, and a number of projects were stalled. However, by the late 1990s exports of reactors and nuclear technologies to Iran, China, and India were negotiated and Russia's stalled domestic construction program was revived with new funds. Russia currently has 32 nuclear power reactors in operation providing about 10 percent of the nation's total electricity capacity. With 11 more reactors under construction, Russia is steadily moving forward with plans for more than doubling its nuclear energy output by 2020 (WNA 20110). 
In addition, from the late 1950s through the end of 1994, Russia (previously the Soviet Union) has built more nuclear powered submarines ( 245 total) than all other nations combined. The Russian nuclear fleet also includes guided-missile cruisers; nuclear-powered scientific research, support, and space-tracking vessels; and civilian nuclear-powered icebreakers. Russia's changing strategic and financial situation after the break-up of the Soviet Union in 1991 resulted in a significant reduction of it naval force, leaving only 37 in service as of October 2006. However, while much smaller than prior deployments, the current Russian nuclear fleet still represents the world's second largest nuclear submarine force after that of the United States. Thus, Russia faces not only decommissioning challenges of the submarines it no longer needs or cannot maintain, but also modernization and maintenance concerns of its remaining fleet (NTI 2007).

\section{Regulation and Legislation}

Prior to the 1980's, an independent nuclear regulatory body did not exist in the Soviet Union and radioactive waste management was primarily supervised by the State Sanitary Surveillance of Public Health Ministry, who really only looked at radioprotection considerations. In 1983, the State Committee for Safety Regulation in Atomic Power (Gosatomenergonadzor) was established and implemented supervision over safety of nuclear power plants (NPPs), research reactors, and nuclear ships for peaceful purposes. The Gosatomenergonadzor did not command much authority until well after the 1986 Chernobyl accident, which lifted the veil of secrecy that the USSR had maintained over its nuclear program and highlighted the necessity for strong regulation and enforcement of safety principles in the nuclear field.

The Russian nuclear related agencies and federal ministries went through multiple stages of restructuring and consolidation beginning in the late 1980's. In 1989, the Gosatomenergonadzor and Gosgortechnadzor (State Committee for the Supervision of Safety in Industry and Mining) were combined to form the USSR State Committee for the Supervision of Safety in Industry and Nuclear Power (Gosatomnadzor), the Russian equivalent of the US Nuclear Regulatory Commission (NRC). In 2004, the Ministry for Industry and Energy (MIE) was created to bring together the two main sectors - energy and weapons. As such, the MIE, among other things, not only incorporated Gosatomnadzor, but also assumed most of the duties of the Ministry of Atomic Energy (Minatom), the Russian equivalent of the US Department of Energy (DOE) (Bouldin 2004; Bradley 1997). Under the MIE, the Federal Agency for Atomic Energy (Rosatom) was created as the state body specifically responsible for nuclear power and nuclear weapons. In 2007, a law transformed the federal agency into a state corporation. The State Atomic Energy Corporation (SC Rosatom) is the largest utility in Russia incorporating more than 250 enterprises and scientific institutions, including all civil nuclear companies of Russia, nuclear weapons complex's facilities, and research organizations. Today, SC Rosatom is responsible for the management of Russia's military and civilian related nuclear assets (NTI 2010), gathering under one roof all structures of the atomic industry, beginning with uranium mining and its enrichment to decommissioning nuclear installations and disposal of radioactive waste. The SC Rosatom's National Enterprise for Radioactive Waste Management (RosRAO) commenced operation in 2009 under a temporary agreement pending finalization new radioactive waste management legislation. RosRAO also incorporates Radon, which was created in 1961 to develop management solutions for accepting, transporting, processing, and storing of radiological waste produced outside of fuel cycle (e.g., medical, scientific, and industrial) (WNA 2011y; Nikitin 2010; Rus Fed 2008; NTI 2003b).

In general, radioactive waste management was considered an issue of minor importance and no regulations related to its handling or storage were approved prior to the breakup of the USSR. 
The Environmental Protection Act of 1991 (revised in 1993) was the first major environmental legislation that included specific clauses pertaining to radioactive wastes. Since 1992, numerous attempts, with limited success, have been made to enact federal radioactive waste management legislation and comprehensive programs (Bradley 1997). The most recent effort has been in the form of the draft law, entitled "On Management of Radioactive Waste," which was initially developed in 1995. Over the last couple of decades, the draft law has evolved as a result of numerous governmental rejections, revisions, and amendments into a dramatically different version than the original (Johnson 2009). In general, the proposed legislation will provide a regulatory, economic, and legal framework and mechanisms to support safe management of legacy and future radioactive waste. A few of the favorable and concrete provisions offered by the draft law's more than 40 articles include: establishing basic definitions for the key terms and concepts used in the sphere of radioactive waste management; providing the necessary guidelines for the management of different types and categories of radioactive waste; setting requirements for storage and disposal sites; prohibiting the disposal nuclear materials and radioactive waste in water bodies (see the next section below for more details on Russian water-related disposal practices); and identifying the owners of storage sites as legally responsible for hazards to human health of the local population and the well-being of the environment (WNA 2011y; Nikitin 2010; Rus Fed 2008).

A law on radioactive waste is extremely necessary and long overdue for Russia. The most recent and evolving draft has been rather controversial over the years and the public has been generally dissatisfied with its overall scope and content. There have been three main issues specifically identified in regards to the development of the draft law. First, some drafts of the law would legalized the existing practice of injecting liquid radioactive waste into underground geological formations for disposal (see the next section below for more details on deep-well injection practices in Russia). Second, draft documents do not require the consultation or approval of local populations on the discussion making proses surrounding the placement of nuclear repositories. Basically, the official decisions with regard to designing, siting, building, operating, and closing of radioactive waste disposal sites shall be made by the Russian federal government, with local executive bodies simply informed of the fact that a decision has been made to build a facility in their region and local legislative branches having no say in the matter whatsoever. Ultimately, this means that the population residing in areas where authorities decide to build radioactive waste storage sites will be basically excluded from the decisionmaking process. Thirdly, the draft law describes the obligations and responsibilities of radioactive waste producers and specialized enterprises engaged in managing radioactive waste, which in turn offers, a partial measure of clarity as to the question of accountability. The draft law places the burden of financial responsibility for managing and final disposal of radioactive waste specifically on the waste producers. Money collected from the radioactive waste generators will be accumulated by the SC Rosatom's and placed in a special reserve fund, handled by a national operator, but under the control of SC Rosatom. It is unclear, however, precisely how these funds will be used or supervised. In addition, this stipulation on fiscal accountability will not apply retroactively to legacy wastes, which will remain the financial responsibility of the federal budget (i.e., taxpayers) and other such sources of funding. In conclusion, many believe that the passing of this law will not produce the necessary foundation needed to shift and improve the way Russia handles the many issues it faces in the field of safe management of radioactive waste, and may, under certain circumstance, even worsen the current radioactive waste management situation (Nikitin 2010; Johnson 2009).

In July 2011, Russia's government finally passed and signed a revised version of the Radioactive Waste Management Law, after nearly two years of consideration and numerous amendments. In summary, the new law establishes a legal framework for radioactive waste 
management and provides for a national radioactive waste management system meeting the requirements of the Joint Convention on the Safe Management of Spent Nuclear Fuel and on the Safe Management of Radioactive Waste ratified by Russia in 2006. SC Rosatom will be responsible for coordination and execution of works associated with radioactive waste management, notably its disposal. The law establishes time limits for interim radioactive waste storage, sets volume limits for waste generators, defines how generators should bring wastes in condition suitable for disposal, and outlines procedures for waste transfer to the national operator along with payment of disposal charges. In addition, the new law specifically prohibits disposal of liquid wastes into geological formations and bans the import and export of radioactive waste. Further legislation on used fuel and high-level wastes is envisaged (WNA 2011y).

\section{Waste Management Practices and Facilities}

It has been estimated that, as of the end of 2007 , more than 470 million $\mathrm{m}^{3}$ of liquid and about 80 million tons of solid radioactive waste have been produced and accumulated as a result of Russian nuclear activities. Currently, major amounts of radioactive waste is said to be located in 43 regions of the Russian Federation at nearly 140 enterprises in more than 1,400 temporary storage facilities and three deep geological facilities (Rus Fed 2008). A severe shortage of radioactive waste storage facilities, coupled with a lack of funding for new sites, has led to the precarious situation that currently threatens both security and the local environment of Russia (NTI 2010).

Russia's weak economy in the years following the collapse of the Soviet Union had a detrimental effect on its ability to deal effectively with the handling, storage, and disposal of radioactive waste and spent nuclear fuel. Historically, the Soviet Union and Russia have disposed of radioactive waste in three ways: dumping it into the Baltic and Arctic Seas as well as into the northern Pacific (primarily the Sea of Japan); storing radioactive waste on nuclear ships servicing the Northern and Pacific fleets of the Russian Navy; and placing it in land-based storage and disposal sites across the country (NTI 2010).

\section{Sea and Naval-Based Activities}

In the late 1980s, Soviet citizens began to voice concern over reports regarding the sea-based dumping of low-level radioactive waste and nuclear ship reactors by the Russian Navy and Murmansk Shipping Company, which operates Russia's fleet of nuclear icebreakers. As a result of these reports and an increasing public demand for more information, a government commission was formed to further investigate Russia's legacy of sea-based radioactive waste dumping. The commission focused on Russia's compliance with its international commitments and how dumping of radioactive waste would affect environmental safety in the future. The outcome of this investigation was a report, released in 1993, known as the White Book or Yablokov Report (named after Professor Aleksey Yablokov, who was head of the commission and President Boris Yeltsin Yeltsin's adviser on environmental issues). According to the White Book, the Soviet Union had been dumping radioactive waste into the seas since 1959 (Cochran et al. 1995). The dumping of radioactive waste into the sea, which was sanctioned by the USSR Ministry of Health (Minzdrav), was prohibited in July of 1993 by decree of the Russian Federation Government (Perovskiy 2011). 
In the Artic, twelve Russian Navy Northern Fleet facilities on the Kola Peninsula and two shipyards in Severodvinsk were responsible for the majority of the radioactive waste dumped. The majority of the solid radioactive waste in the Northern seas is LILW generated by nuclearpowered ships and submarines, which was dumped into eight areas of the Kara Sea, primarily in shallow bays on the eastern coast of Novaya Zemlya. Liquid radioactive waste was primarily dumped into five designated areas in the Barents Sea, and by 1992, the total volume of LRW dumped into the Barents Sea at all five sites was estimated to be more than $190,000 \mathrm{~m}^{3}$ (Cochran et al. 1995). The Russian Navy Pacific Fleet and naval facilities also deposited liquid and solid radioactive waste in ten designated areas within three Far East bodies of water: the Sea of Japan, the Sea of Okhotsk, and the North Pacific Ocean. The solid waste consists of LILW, similar to that in the Northern seas, dumped in four of the designated areas. However, in contrast with the North, the solid waste did not contain any reactors with spent nuclear fuel still in them. Liquid waste was dumped in nine of the ten designated areas, and as of 1992, the total volume of liquid radioactive waste dumped into the Far Eastern seas amounted to more than $120,000 \mathrm{~m}^{3}$. The last known incident of dumping at sea by the Russian Navy was in 1993, when approximately 900 tons of liquid radioactive waste was dumped into the Sea of Japan (Cochran et al. 1995). Currently, many of the same vessels previously used for the collection and dumping of waste into the sea are being used to transport and store radioactive waste, referred to as floating maintenance bases (FMB). The primary holding place for these FMB, along with decommissioned nuclear submarines and their components awaiting dismantlement and storage (pictured in Figure 40), is Sayda Bay on the coastal strip of the Kola Peninsula (Perovskiy 2011; Cochran et al. 1995).

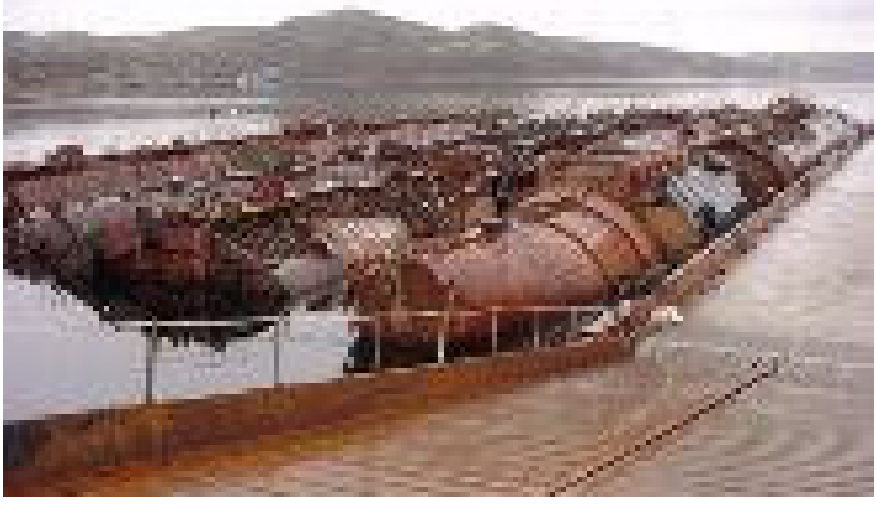

Figure 40. Floating reactor compartments awaiting long-term storage in Sayda Bay (BMWi 2011)

Since the end of the Cold War, Russia has decommissioned most of its Northern Fleet submarines for reasons of cost and age, as well as to meet various disarmament treaty obligations. At the 2002 summit for the G8 (The Group of Eight, a forum for the governments of major economies: France, Germany, Italy, Japan, United Kingdom, United States, Canada, and Russia) a new Global Partnership Against the Spread of Nuclear Weapons and Materials of Mass Destruction was launched. This partnership aims to prevent terrorist access to, and the spread of, nuclear weapons and materials of mass destruction, and under which the G8 states will undertake cooperative projects on the basis of agreed guidelines. One of Russia's top priorities as a member of the Global G8 Partnership is to dismantle the Russian navy's nuclear powered vessels in an environmentally safe manner. The guidelines adopted at the 2002 G8 summit laid the groundwork for not only the safe defueling, dismantlement, and land-based long-term interim storage (for up to 70 years) of Russian decommissioned nuclear submarines and surface vessels, but also the construction of a processing and storage facility for all LILW nuclear waste from radioactive elements in northwest Russia. 
The Sayda Bay long-term storage facility, located on nearly 14 acres (5.5 ha), aims to establish a land-based long-term interim storage facility for 150 reactor compartments, two complete nuclear submarines, and 26 additional reactor compartments from surface vessels (e.g. atomic icebreakers, cruisers, and service ships). The facility design is illustrated in Figure 41.

The design calls for decommissioned nuclear powered vessels, as well as reactor compartments that are currently floating in Sayda Bay (pictured in Figure 40), to be towed to the Nerpa shipyard on a floating dock, where they will be dismantled. The reactor compartments will be separated, hoisted out of the water, sealed, and transported on rails to the concrete platform of the interim storage area (as pictured in Figure 42). The front and rear sections of the submarines will be dismantled in the conventional fashion and the metal components will be scrapped for recycling. Phase one of the storage facility opened for operation in July 2006. Construction of phase two, which included the final 58 storage spaces, was finished in 2009, with the exception for the repair shed and some residual road-building work scheduled for completion by late 2010. All ongoing construction work has no effect on the storage of reactor compartments (BMWi 2006; BMWi 2011).


Figure 41. Overview of the Sayda Bay long-term storage facility conceptual design and layout (BMWi 2006)



Figure 42. Reactor compartments on land at the interim storage facility in Sayda Bay (BMWi 2011)
The Regional Centre for Conditioning and Storage of Radioactive Waste (TsKDKh RAO) will be located on 50 acres (20 ha) adjacent to the site of the Sayda Bay reactor compartment long-term interim storage facility. The disposal Centre is intended to completely finish the disposal chain for nuclear submarines in the northwest of Russia. The design, illustrated in Figure 43 , is intended to include a complex (white building on the left side illustration in Figure 43) for the acceptance, decontamination, conditioning, and packaging of radioactive materials and for the assessment of material which can potentially be returned to the economic cycle following treatment (BMWi 2006; BMWi 2011; Perovskiy 2011). 


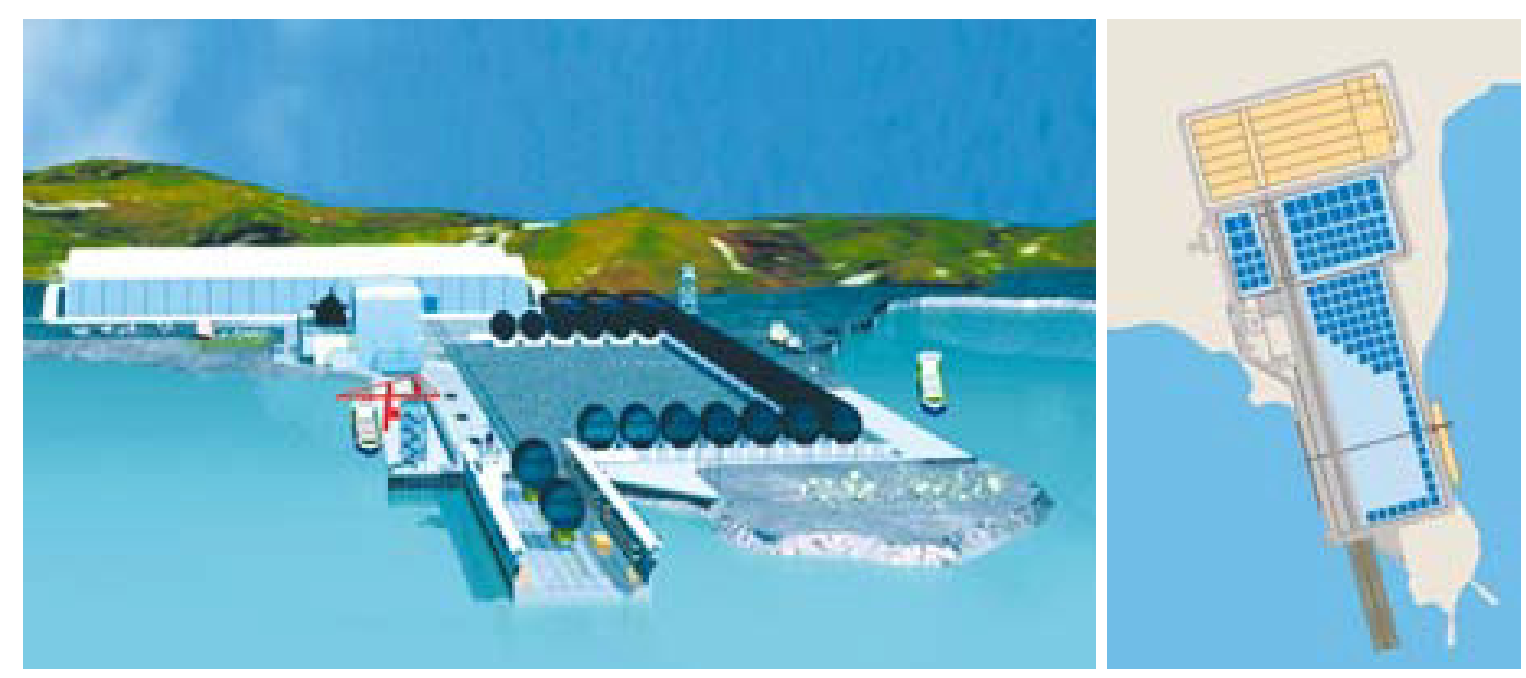

Figure 43. Envisioned Sayda Bay disposal Centre at the current location of the long-term storage facility (BMWi 2006)

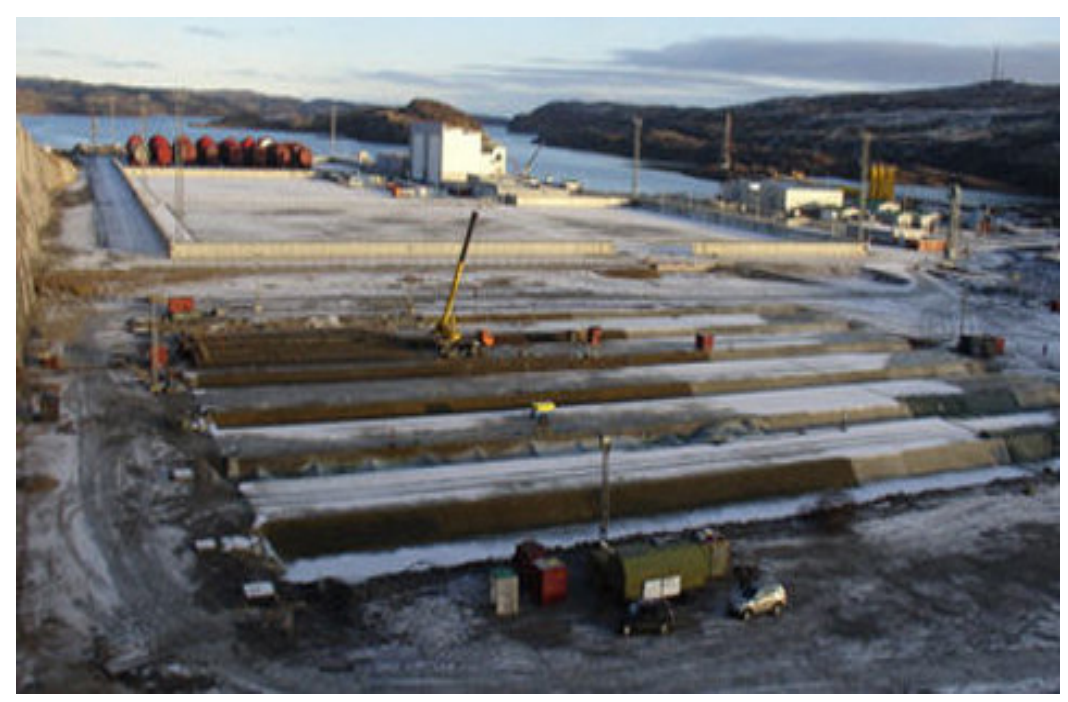

Figure 44. Sayda Bay construction site as of October 2009 (BMWi 2011) scheduled for completion at the end of 2014. Construction is financed by Germany within the scope of the Global Partnership program, scientific accompaniment and project design are being performed by Russian institutes, and all decisions have been approved by the expert community (BMWi 2011).

\section{Land-Based Activities}

For the remainder of Russia, national land-based radiological waste repositories do not yet exist in Russia. For about 45 years, SC Rosatom and its predecessors have been collecting, transporting, treating, and storing LILW generated in nuclear, scientific, and social institutions and some industrial enterprises throughout the nation (Dmitriev 2007; SC Rosatom 2011). Over the years, the majority of the LILW waste has been disposed of either at near-surface sites (rarely utilizing sufficient barriers to contain the waste long term) or by using deep-well 
injections. However, the end of the Cold War revealed the regular and continuing practices of storing radioactive waste in open reservoirs and dumping it directly into natural surface and ground water bodies (Cochran et al. 1995; NTI 2010; Bradley 1997).

There are a large number of near-surface burial sites throughout Russia. In general, the primary principle applied to the disposal of radioactive waste in Russia is simply to reduce the distance between the production site and the waste burial site to a minimum (Cochran et al. 1995). Thus, disposal site were typically located at or near the point of production, so nearly every nuclear facility and plant had, and still has, its own burial site for its radioactive waste.

A prime example of Russian land-based disposal practices is the Mayak nuclear complex (also referred to by the Russian code name Chelyabinsk-65), situated in western Siberia about $15 \mathrm{~km}$ east of the city of Kyshtym on the east side of the Southern Urals. The original Mayak plant began operations in 1948 as a plutonium production complex for weapons, but later specialized in plutonium reprocessing from decommissioned weapons and reactor wastes. Today, the plant makes tritium and radioisotopes. Since it began operation, the radiological contamination resulting from the Marak disposal practices has been a known source of serious regional contamination, which was kept secret by the Soviet regime for about 30 years. During the first few years of operation, radioactive waste management was practically nonexistent. Through the 1950s and into the 1960s, the Mayak complex practiced direct dumping for all levels of liquid

Techa River and Villages in 1951

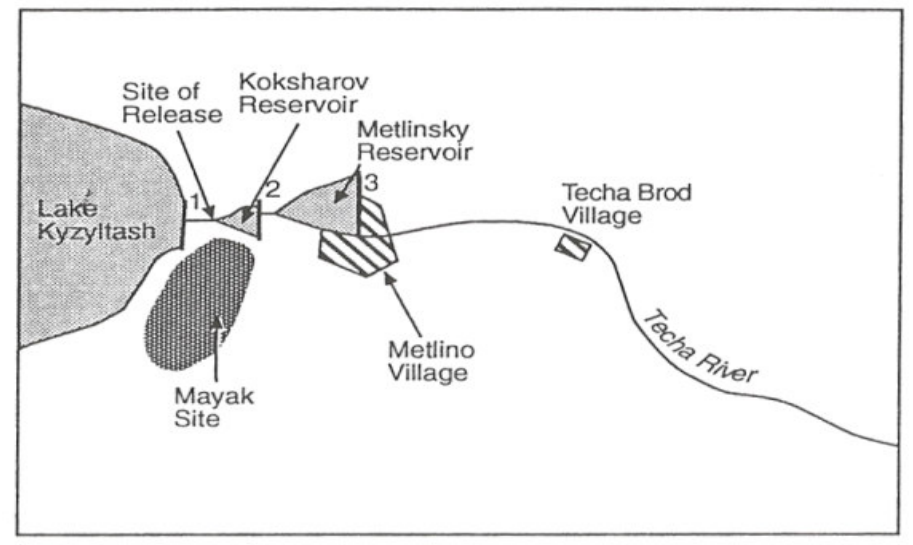

Techa River and Reservoirs in 1961

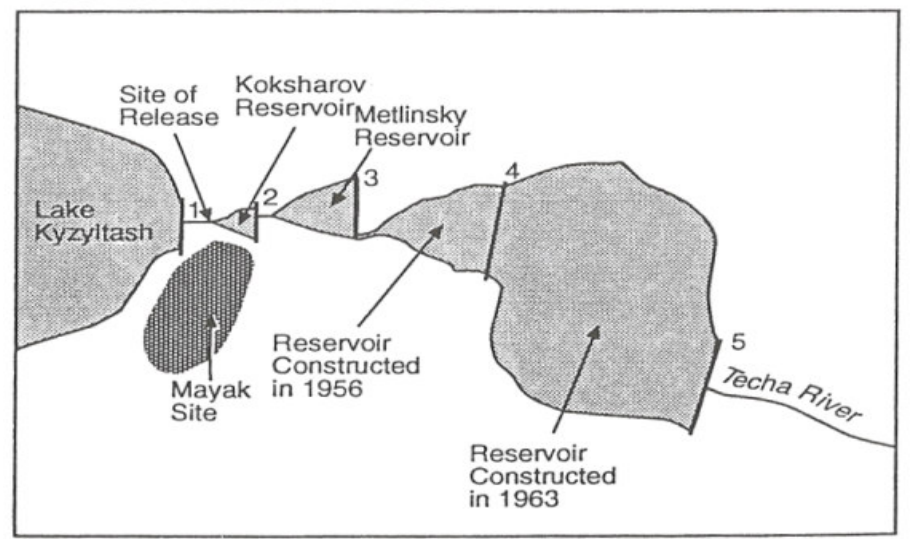
radioactive waste into the Techa River, Lake Karachary, Lake Staroe Boloto, and other area reservoirs. Figure 45 provides an illustration of the evolution of reservoirs at the Mayak site and Figure 46 provides an aerial satellite view of the site and surrounding area today. Although dumping into the Techa River ceased in 1956, liquid LILW continues to be dumped into the lake and reservoirs around the Mayak even today. As a result, there is more than 340 million $\mathrm{m}^{3}$ of liquid radioactive waste in open reservoirs on site.

Figure 45. Evolution of reservoirs at the Mayak site (Bradley 1997) 
Solid and solidified liquid LILW is typically buried in clay lined trenches dug in the ground and without being processed, due to a lack of proper facilities (e.g. incinerators, compactors, etc.) to treat the waste. After being filled, the trenches are covered with a layer of clay. The burial sites for LILW are located in areas where the water table is greater than $4 \mathrm{~m}$ below the bottom of the trench. However, the clay lining offers little protection from water infiltration and radionuclide migration from the burial sites. As of the 1990's, there were more than 230 solid waste burial sites (about 10 percent still receiving waste) comprising total area of about 74 acres (30 ha), with the burial sites occupying more than 50 acres ( $21 \mathrm{ha})$. This site contains more than 500,000 tons of solid waste, of which nearly 30 percent is LLW and more than 65 percent is ILW (NTI 2003a; Cochran et al. 1995; Bradley 1997).

Deep-well injection of liquid radioactive waste involves the pumping of liquid wastes under pressure into deep underground porous rock formations, which are separated by low and impermeable layers. The more than 20 sites throughout Russia that have or currently use the injection method, such as those in Seversk and Zheleznogorsk, typically have wells ranging

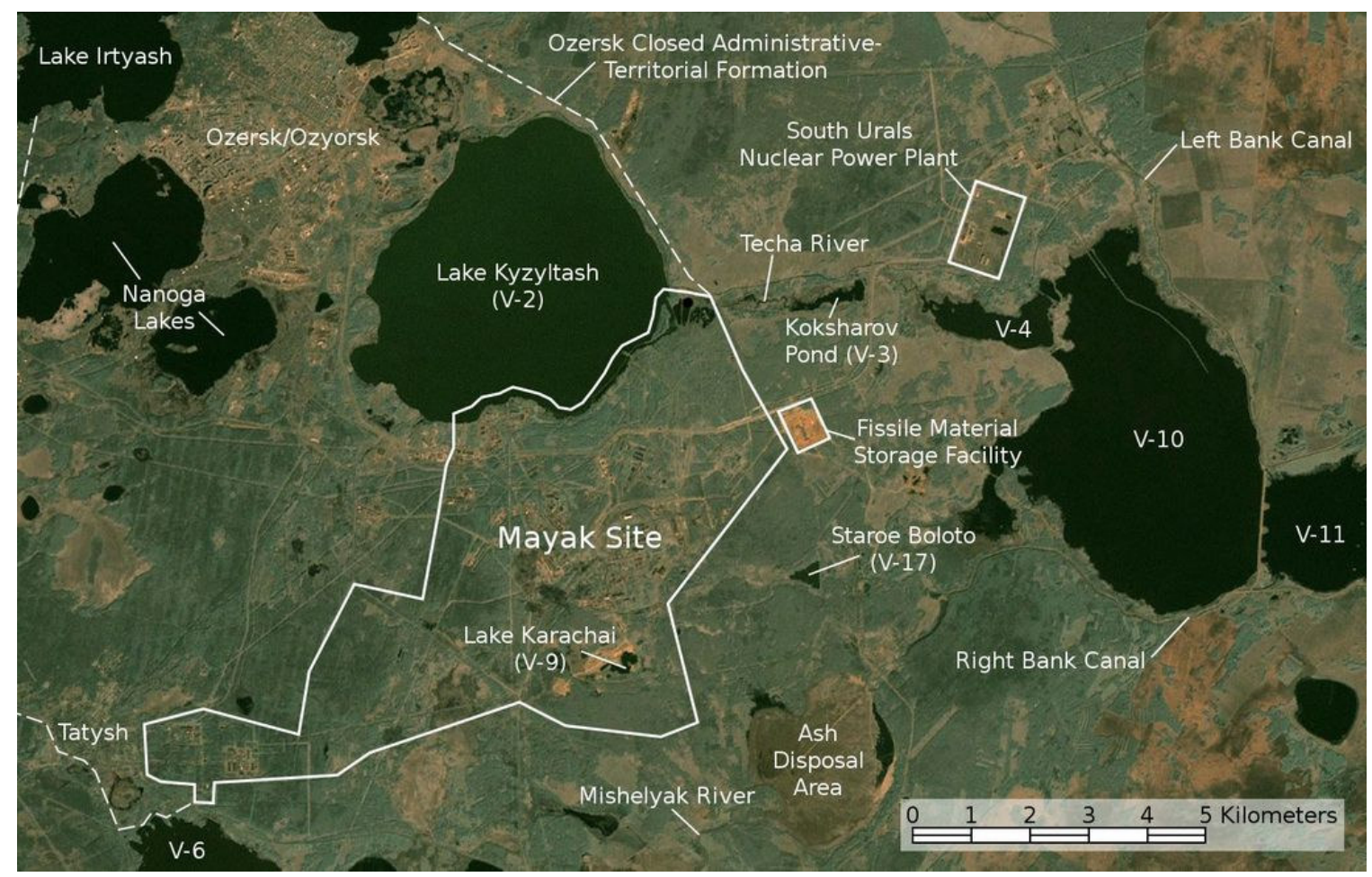

Figure 46. Satellite view of the Mayak site (Rieke 2010)

from 150 up to $500 \mathrm{~m}$ deep, but can go as deep as 2,600 $\mathrm{m}$ for disposal. After the waste is injected, it will neither be treated nor removed. However, this method provides no guarantees that, once underground, the liquid waste will not migrate and penetrate into adjacent aquifers (e.g., the Seversk and Zelenogorsk sites are located within a few km of the edge of the Western Siberian artesian groundwater basin), with the risk that radionuclides will then end up contaminating water supply systems in populated areas (Bradley 1997; Cochran et al. 1995; WNA 2011y; Nikitin 2010). It has been stated that deep-well injection is the only radioactive waste management technology currently used in Russia on the industrial scale (Bradley 1997); although it is extremely unpopular among the general public (Nikitin 2010). And even though the IAEA does not have any relevant regulations that might provide specific guidelines for such 
a method of disposing of liquid radioactive waste, this practice has delayed Russian acceptance of an IAEA standard for radioactive waste disposal in general, since the deep-well injection disposal method has no packaging or engineered barriers and relies on the geology alone for safe isolation (WNA 2011y; Nikitin 2010).

The Siberian Chemical Combine site, in the Soviet Union secret city and still closed town of Seversk (formerly known as Tomsk-7), was opened in 1954 and is made up of several large facilities, including a nuclear power station, fossil fuel plant, chemical separations plant, plutonium processing and storage facility, uranium enrichment plant, and nuclear waste management facilities. The site and its sanitary protection zone is said to occupy an area of more than 50,000 acres $(20,000$ ha). Over the course of plant operations, nearly 130,000 tons of solid and more than 30 million $\mathrm{m}^{3}$ of liquid wastes have accumulated at the Seversk site. The majority of the liquid waste, of unknown concentrations, has been pumped into sandy beds at a depth of 250 to $460 \mathrm{~m}$, as depicted in Figure 47 (Cochran et al. 1995; GlobalSecurity 2005b).

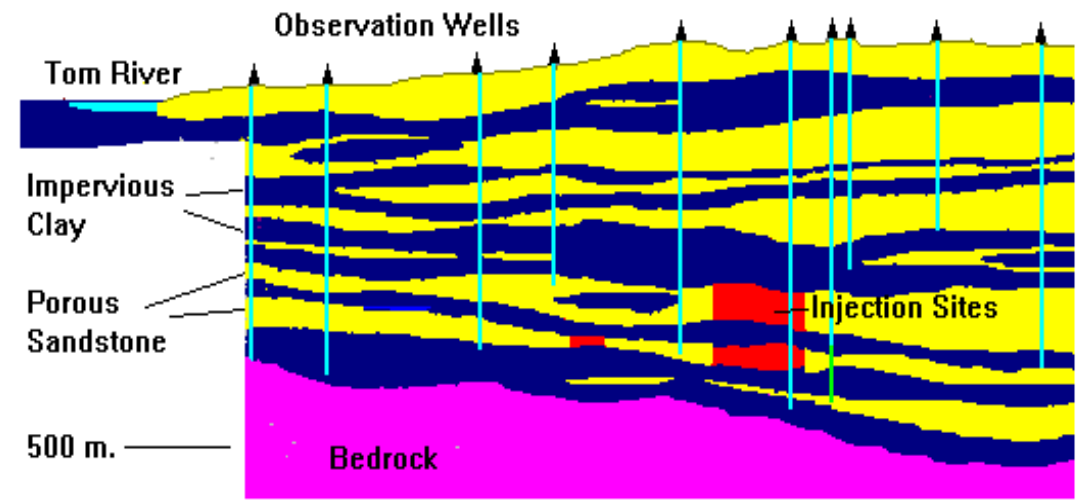

Figure 47. Underground injection sites at Seversk (Dutch 1999)

The Mining and Chemical Combine site, in the Soviet Union secret city and still closed town of Zheleznogorsk (formerly known as Krasnoyarsk-26), covers an area of about 4,200 acres $(1,700 \mathrm{ha})$ within a larger sanitary protection zone of greater than 32,000 acres $(13,000 \mathrm{ha})$. The site began operation in 1958 and is comprised of three plutonium production reactors, a fossil fuel plant, a coolant water preparation plant, a chemical separation plant, a radiochemical reprocessing plant, waste treatment and storage, and numerous auxiliary facilities. The majority of the major production and separation facilities are located within a huge multilevel cavern some 200 to $300 \mathrm{~m}$ underground. The waste injection site, known as the Northern or Severny Site, is approximately $15 \mathrm{~km}$ north-west of the main underground facility. Since 1967, there have been more than 100 injection, relief, monitoring, and observation wells drilled at the site. The subsurface environment consists of a sand and clay strata reaching about $450 \mathrm{~m}$ below the ground surface upon crystalline bedrock. LLW is injected into an aquifer spaced within the sedimentary layers at a depth of about 150 to $280 \mathrm{~m}$; whereas, ILW is injected into another aquifer at a depth of about 350 to $500 \mathrm{~m}$ below the surface. As of 1992, when two of the three production reactors shut down, more than 2.5 million $\mathrm{m}^{3}$ of LLW and 2 million $\mathrm{m}^{3}$ of ILW had been disposed of in the manner (Cochran et al. 1995; GlobalSecurity 2005a; Compton et al. 2000; Bradley 1997).

On the non-nuclear fuel cycle side of radioactive waste disposal, Radon has an estimated 16 to 30 LILW storage repositories located throughout Russia, however, many facilities and disposal sites are filled to capacity (WNA 2011y; NTI 2003b; IAEA 2001a). In general, Radon has utilized near surface reinforced concrete repositories for LILW disposal. Most of these repositories are excavated into the soil, although some have both above-grade and subsurface disposal cells, with typical dimensions of $60 \mathrm{~m}$ long, $20 \mathrm{~m}$ wide, and $4 \mathrm{~m}$ deep The cells have waterproof lining on the bottom and walls and hold waste forms in various packages emplaced in alternating 
layers of waste and cement mortar. The immobilization of the waste and protection against radionuclide migration are achieved by application of the multi-barrier principle, with additional protection from the waste matrix materials (concrete, glass, bitumen, metal), the package (concrete or steel container, metal drum, lead container), and stabilizing backfill materials (cement mortar, cement-clay mortar, natural sorbents) (IAEA 2001a).

\section{Current and Future Initiatives}

One of the key factors determining Russian policy and practices of radioactive waste management has been the presence of a significant amount of historical spent fuel and waste resulting from national defense programs, combined with the substantial financial constraints of the past couple of decades caused by the disintegration of the USSR (Rus Fed 2008). A first step in getting a handle on Russia's current radioactive waste situation and determining the path forward should include a complete inventory of all existing waste, the sites it is being stored at, and the condition of its placement (Linge 2009).

In the near-term, beyond the need for comprehensive federal radioactive waste management legislation and a unified state system, the principle challenge facing the Russian Federation is the need for a reduction of radioactive waste volumes. The strategy for resolving this issue is really two-fold. First, and among the most urgent ecologically, Russia must focus on reducing the fraction of waste stored in non-environmental isolated facilities (e.g., open surface reservoirs) and rendering these facilities safe. Remediation objectives include mitigating the radiation exposure from existing areas of contaminated land so as to reduce current and prolonged exposures and eventually releasing the land for unrestricted use. Second, one of Russia's main tasks must be to develop and establish new radioactive waste conditioning capacities, followed by controlled storage. These new conditioning procedures will need to include techniques to minimize and eliminate existing stored waste, such as through separation, clean-up, and repackaging of materials that have lost their activity (Perovskiy 2011; Rus Fed 2006; Rus Fed 2008). The waste conditioning and disposal efforts are especially pertinent when looking towards the future, considering the availability of storage space within current waste management facilities and the fact that Russia anticipates an increase in the volumes of generated radioactive waste due to expansion of both energy and weapons decommissioning activities (Rus Fed 2006).

As of 2008, there were tentative plans to develop new and modernize existing radioactive waste repositories. Included in this vision is the refurbishing of more than 15 waste storage facilities, establishment of four to six regional waste repositories for LILW containing short-lived radionuclides, and construction of one or two repositories for wastes containing long-lived radionuclides. The most recent update to these plans was in 2010, when RosRAO revealed intentions to draft a general scheme with locations of radioactive waste repositories (from both nuclear power plant operations and nuclear weapons disposal) to be set up by 2020-2035. (WNA 2011y; Rus Fed 2006)

\subsection{Sweden}

\section{Nuclear Capabilities}

Sweden's first reactor, an experimental research reactor, located in an underground rock cavern in Stockholm went critical in 1954. It was not until 1972 that the first commercial nuclear reactor 
was commissioned. Five additional reactors entered commercial service in the 1970 s and six in the 1980s. These 12 reactors are located at four sites (Barsebäck, Ringhals, Forsmark and Oskarshamn) around the southern coast of Sweden. As a result of political decisions (described in more detail in the next section), two units were permanently shut down in 1999 and 2005 respectively. Currently, Sweden has 10 operating nuclear power reactors, at three sites (Ringhals, Forsmark and Oskarshamn), providing approximately 40 percent of its domestically produced electricity. The power percentage changes from year to year depending on hydroelectric resources following winter precipitation. To manage these fluctuations, Sweden also imports and exports electricity, according to season, primarily with Finland, Norway, and Denmark. In general, electricity imports balance out exports, with a small net flow in from Norway and out to Finland (WNA 2011q; Sweden 2010, $5^{\text {th }}$ ).

\section{Regulation and Legislation}

In general, the objective of Swedish energy policy is to ensure reliable and economically competitive supplies of energy with minimum adverse effect on health, the environment or climate. In 1980, as a result of the Three Mile Island accident in the USA, the Swedish government passed a referendum to phase out nuclear power and aim for closing the 12 operating plants by 2010 , assuming new energy sources were available to realistically replace them. The Chernobyl disaster in 1986 created some pressure to progress the issue of nuclear decommissioning and in 1988, the government decided to begin the phase-out in 1995; however, this decision was ultimately overturned in 1991. The country's 1997 energy policy allowed 10 reactors to operate longer than envisaged by the initial 1980 phase-out policy (i.e., closing 2012 to 2025), but also resulted in the premature closure of the two reactors at the Barsebäck NPP site (situated in the south of Sweden $30 \mathrm{~km}$ from Malmö and only $20 \mathrm{~km}$ from Copenhagen). Its two reactor units were shut down in 1999 and 2005, respectively; but, neither of these is expected to be dismantled or decommissioned until around 2020. Finally, in June 2010, in response to increasing electricity prices, concerns over climate change, and overwhelming majority of public opinion, Parliament voted to repeal this phase out policy and allow for construction of new reactors at existing sites as replacements for those which would be retired, beginning with four due for shutdown in 2020 (WNA 2011q).

The basis of Sweden's legislation in the field of waste management, nuclear safety, and radiation protection can be found in four main legislative instruments. The Act on Nuclear Activities (1984) defines the licensing requirements for the construction and operation of nuclear facilities and for handling or using nuclear materials (including radioactive waste). This Act also identifies the holder of a license to operate a nuclear reactor primarily responsible for the safe handling and disposal all waste produced. The Radiation Protection Act (1988) defines the licensing requirements for radiological work and protection and requires the licensee to take all measures and precautions necessary to prevent or counteract radiation injury to human health and the environment. The Act on Financing of Management of Residual Products from Nuclear Activities (2006) outlines the principles of the financing for decommissioning and the disposal of nuclear waste. Finally, the Environmental Code (1998) provides for the siting and construction of new facilities, including the environmental impact statement that must accompany a license application. These Acts are further supplemented by a number of ordinances and other secondary legislation, which contain more detailed provisions for particular aspects of the legal framework (OECD-NEA 2009b; Sweden $20105^{\text {th }}$; Sweden 2008).

Since 2008, Sweden's integrated regulatory body for nuclear safety, radiation protection, and compliance of operations with legislation and regulations has been the Swedish Radiation Safety Authority (SSM), which is a result of a merger of the two earlier regulatory bodies: the 
Swedish Nuclear Power Inspectorate (SKI) and the Radiation Protection Authority (SSI). The roles and responsibilities of the SSM include radiation protection, nuclear safety, and regulation of all nuclear activities. The Ministry of the Environment is the official agency responsible for radioactive waste management, and the SSM reports to this Ministry. In the mid-1970s, the nuclear push became a political issue and legislation was passed in 1977 to ensure proper waste management. As a result, the Swedish Nuclear Fuel and Waste Management Company (Svensk Kärnbränslehantering $A B, S K B$ ) was formed by the nuclear utilities as the implementer of the radioactive waste management and disposal program in Sweden; however, the state maintains the ultimate responsibility for all nuclear and radiological waste (WNA 2011q; SKB 2006; OECD-NEA 2009b; Sweden 2008). Currently, there is no legally defined waste classification system in Sweden for radioactive waste; however, general waste acceptance criteria expressed as dose rate limits and activity concentration has been established for the different radioactive waste disposal routes, including clearance for disposal as conventional non-radioactive waste, shallow land burial, and repository placement (OECD-NEA 2009b; Sweden 2008).

The expenses for the disposal nuclear waste are to be covered by revenues from the production of nuclear generated energy that has resulted in these expenses. Thus, the nuclear utilities make payments into the Swedish Nuclear Waste Fund (Kärnavfallsfonden) to cover their share of the total costs for the safe handling, transportation, management, and disposal of radioactive waste produced, as well as dismantling nuclear facilities and disposing of the decommissioning waste. The Fund must also finance SKB'S R\&D activities. The SSM reviews the cost calculations every three years and submits a proposal to the Government for the size of the updated fees based on each individual utility. Thus, a separate fund exists for each utility. Contributions are made during the first 25 years of operation, in effect the normal operating lifetime of a nuclear reactor (WNA 2011q; WNA 2011x; OECD-NEA 2010b). In addition, a special fee has been levied since 1989 on the nuclear power utilities according to the Studsvik Act (1988). This fee, which is the same for all the utilities, is intended to cover expenses for the management of nuclear waste from and dismantling of older experimental facilities, including the test facilities at Studsvik (Sweden 2008).

\section{Waste Management Practices and Facilities}

The Swedish nuclear power program, including the Studsvik research facilities, will generate approximately $60,000 \mathrm{~m}^{3}$ short-lived LILW, 16,000 $\mathrm{m}^{3}$ long-lived LILW, and 160,000 $\mathrm{m}^{3}$ decommissioning waste (based on a reactor operational lifetime of 50-years for Forsmark and Ringhals and 60-years for Oskarshamn). The total annual production of LILW at the nuclear facilities is estimated to be between 1,000 to $1,500 \mathrm{~m}^{3}$ (Sweden $2010,5^{\text {th }}$ ).

Historically, sea dumping of LLW occurred in Swedish territorial waters, as well as in the Atlantic. The last dumping occurred at the end of the 1960's and it has been prohibited in Sweden since 1971 (Sweden 2008). Currently, waste management practices in Sweden for LILW include a transportation system, repository for operational radioactive waste (SFR-1), and shallow land burial. All waste management facilities, unless part of a nuclear power plant or the Studsvik nuclear research facility (which has no operating reactors), are owned and operated by the SKB. 
All transportation of nuclear waste to storage or repositories is by sea, since all the nuclear facilities are situated along the coast and have their own dedicated harbors. The transportation system has been in operation since 1982 and consists of the SKB's specially built and dedicated vessel - the M/S Sigyn, pictured in Figure 48. The ship has a double bottom and a double hull, providing extra high buoyancy and protection of the cargo in the event of collision or grounding. The transport casks and walls surrounding the hold are radiation-shielded and designed withstand major strain, as in the event of an accident. Both waste containers and terminal vehicles, shown in Figure 48, used for loading and unloading are carried on the ship (IAEA 2009e; SKB 2011b).

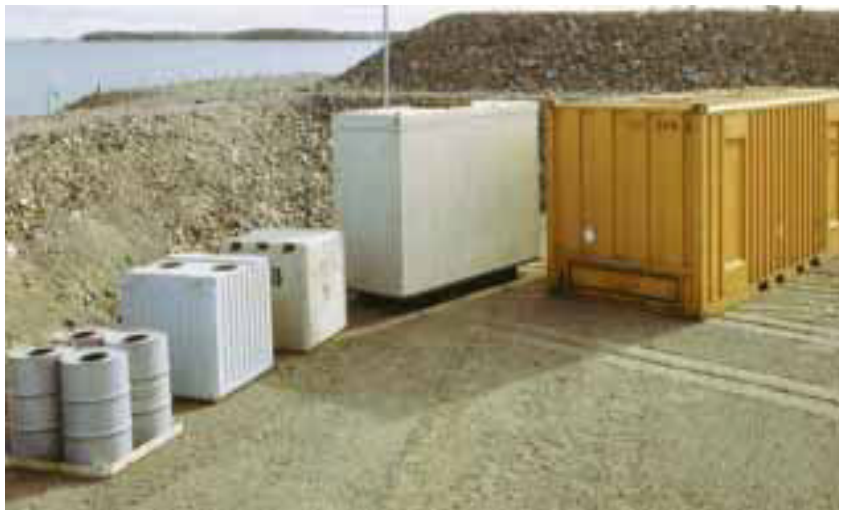

Figure 49. Different types of waste containers for LILW (SKB 2006)

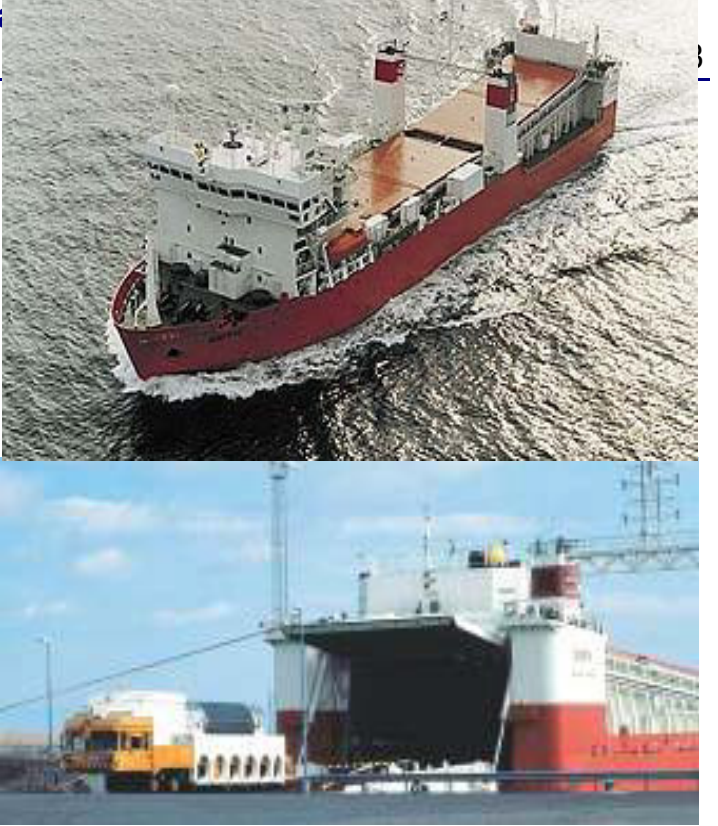

Figure 48. The M/S Sigyn - SKB's custom built nuclear waste ship (SKB 2011b)

The Swedish final repository (SFR-1) for short lived LILW, pictured in Figure 51, has been operating since 1988 in Forsmark, which is also the proposed location for a final HLW repository. The SFR-1 handles the operational LILW waste from the Swedish nuclear reactors, along with the small amounts (10 to $20 \mathrm{~m}^{3} / \mathrm{yr}$ ) of LILW generated by health care, industry, and research facilities (SKB 2011a). The SFR-1



Figure 50. Placement of radioactive waste in the silo and rock vaults (SKB 2006) 
is situated $1 \mathrm{~km}$ from the shore in the crystalline bedrock at depth of $50 \mathrm{~m}$ below the bottom of the Baltic Sea, which has a water depth of five meters, and is accessed by two parallel tunnels connecting from the Forsmark NPP facility site. The majority of the LILW is disposed of in one of four mined rock vaults, each of which has a length of $160 \mathrm{~m}$, widths varying from 15 to $20 \mathrm{~m}$ and heights varying from 10 to $17 \mathrm{~m}$ (IAEA 2001b). In general, the LLW is treated and compacted at the NPPs, packed into containers (e.g., 200-L drums, metal boxes, freight containers, etc., pictured in Figure 49). Because this type of waste does not require any radiation shielding, it is placed directly in the rock vault for low level waste (vaults named BLA) using an ordinary forklift truck (as illustrated in Figure 50). The BLA cavern is very simple in design; basically there is only a concrete floor on which containers are placed. During the operational phase a ceiling has been placed above the waste in order to minimize water dripping onto the waste. This inner roof will be dismantled before the repository is closed (Sweden 2008). About 0.2 percent of the total activity in SFR-1 will be placed in this vault (IAEA 2001b).

The three remaining rock vaults are used to dispose of the ILW (two vaults for dewatered filter resins in concrete tanks and one vault for hard-to-handle waste emplaced in shafts). The waste is handled and placed using a radiation-shielded forklift truck or a remote-controlled overhead crane. The tanks in the two rock vaults for concrete tanks (vaults named BTF) are each $10 \mathrm{~m}^{3}$ in volume and piled in two levels with four tanks in each row. A concrete radiation protection lid is placed on top of the pile after placement. The BTF vaults are also used to dispose of the large reactor components and drums containing radioactive ash. The rock vault for intermediate level waste (BMA) generally houses lower activity ILW contained in concrete molds or metal drums. Inside the cavern a concrete construction has been raised such that the vault is divided

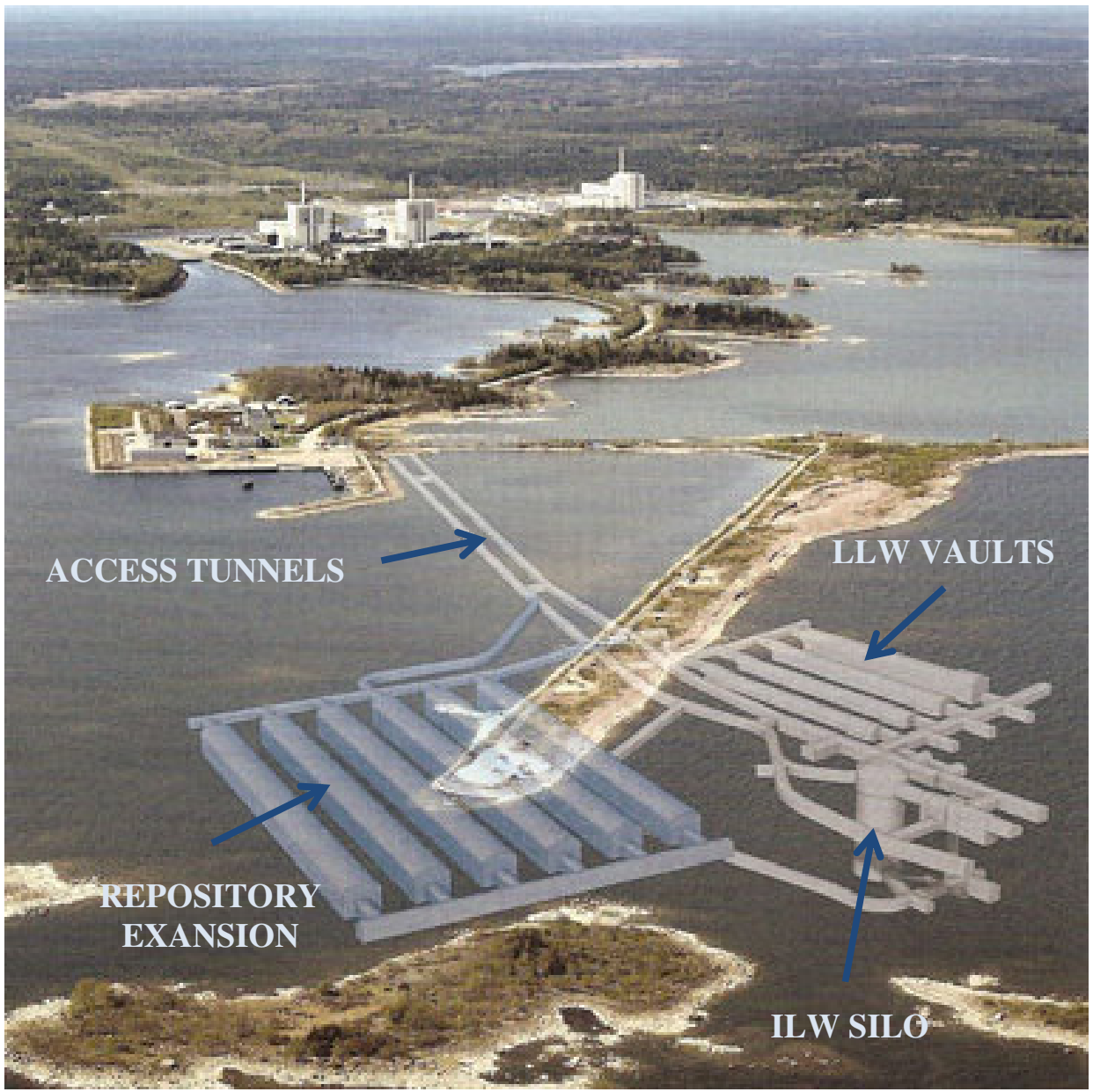

Figure 51. Swedish final repository (SFR) for short lived LILW at Forsmark (BSRRW 2009) 
into 15 compartments. The waste is piled on top of the concrete floor in such a way that the molds act as support for prefabricated slabs, put in position as soon as the compartments are filled (Carlsson 2007; SKB 2011a; SKB 2006; Sweden 2008).

ILW is primarily disposed of in a concrete silo, with a height of $50 \mathrm{~m}$ and an inner diameter of $26 \mathrm{~m}$. Internally, the silo is divided into deep shafts of different sizes (largest measuring $2.5 \mathrm{~m}^{2}$ ) for waste various packages. The ILW is first mixed with concrete and encased in $200-\mathrm{L}$ drums or $1.2 \mathrm{~m}$ cubes of steel or concrete before its disposal. All handling of waste in the silo is automated and performed using remote control equipment (as illustrated in Figure 50). Typically, six meters of waste in layers of four molds or 16 drums are deposited at a time in each shaft, which is then backfilled with porous concrete before any more waste can be stacked on top. The shafts are separated by concrete walls and space between the silo and the rock wall has been filled with bentonite clay (approximately $1.2 \mathrm{~m}$ thick) to prevent groundwater infiltration. Up to 90 percent of the total activity in the SFR-1 will be placed in the silo. The total design capacity of the SFR-1 facility is $90,000 \mathrm{~m}^{3}$, but currently has an operating capacity of $63,000 \mathrm{~m}^{3}\left(45,000 \mathrm{~m}^{3}\right.$ in the vaults and $18,000 \mathrm{~m}^{3}$ in the silo) of which about one-half is in use (Olsson et al. 2008). The SFR-1 receives about 1,000 $\mathrm{m}^{3}$ of LILW per year (IAEA 2009e; IAEA 2001b; Carlsson 2007; SKB 2011a; SKB 2006; Lindberg 2006; Sweden 2008).

When SFR-1 is eventually closed and sealed, the storage rooms and tunnels will be backfilled with sand, gravel, or sand stabilized with cement to provide mechanical support for the rock. They will also be plugged or capped to both mechanically and hydraulically seal the chambers. The closed facility will be surrounded by multiple natural (i.e., surrounding crystalline rock) and engineered barriers (e.g., bentonite and concrete). The primary purpose of the barriers is to help prevent the transport of radionuclides, in case the closed SFR-1 is infiltrated with groundwater from the surrounding rock. Fortunately, because the groundwater pressure beneath the seabed is uniform, the groundwater in the surrounding rock is virtually immobile (i.e., 7,000 years old). Monitoring occurs for groundwater flows, water chemistry, rock movement, the performance of the bentonite barrier, and the properties of the waste to provide the data needed for safety assessments (SKB 2006; Sweden 2008).

Interim storage for LILW also exists at the AM facility on the Studsvik site. The AM facility was constructed in the 1980s and was designed to receive waste until about the year 2020 . The disposal area is located in a crystalline bedrock cavern with a minimum rock cover of $20 \mathrm{~m}$. The rock mass is grouted with concrete, the walls are reinforced by means of rendering concrete, and a special system was created to drain the rock. Waste stored at this facility include: operational waste from the Studsvik research reactors; irradiated and contaminated material from the production of isotopes and fuel testing at Studsvik facilities; incineration products from nuclear power plants, hospitals, and industry; products from the use of isotopes in industry and hospitals; and decommissioning waste from old nuclear facilities. The waste is first conditioned and then packed in containers before being positioned in the storage area, which is divided into two parts: shielded and unshielded. The shielded part of the AM storage facility has a maximum capacity corresponding to 14,400 drums (200-L), while the portion for waste that does not require shielding can hold only 4,600 drums. A further 1,000 drums can be deposited in others parts of the facility. As of the end of 2007, more than 1,700 $\mathrm{m}^{3}$ (2,650 packages) of radioactive waste had been disposed of in the AM facility (Sweden 2008).

Facilities for short-lived very low-level waste (generally containing activity concentrations less than $300 \mathrm{~Bq} / \mathrm{g}$ ) are located at the operating NPPs in Ringhals, Forsmark and Oskarshamn, as well as the Studsvik research site. Waste disposal typically involves shallow land burial performed in campaigns at 3 to 5 year intervals, with the facilities closed in between the 
campaigns. The design and layout of the shallow land burial facilities differs between NPPS, but all facilities have a protective top sealing layer to reduce water infiltration. Figure 52 provides an illustration of the shallow land burial facility at Oskarshamn. The licenses for the burials at the NPPs are valid until 2025-2040. Current inventories and licensed capacities of disposed waste in shallow land burials, as of the end of 2007 , were nearly $3,500 \mathrm{~m}^{3}$ (of $10,000 \mathrm{~m}^{3}$ capacity) at Ringhals, $4,000 \mathrm{~m}^{3}$ (of $17,000 \mathrm{~m}^{3}$ capacity) at Forsmark, 7,350 $\mathrm{m}^{3}$ (of $10,000 \mathrm{~m}^{3}$ capacity) at Orskarshamn, and $1,140 \mathrm{~m}^{3}$ (of $1,540 \mathrm{~m}^{3}$ capacity) at Studsvik (OECDNEA 2009b). In addition, some incineration of combustible VLLW occurs at the Studsvik facility, where the resulting ashes collected in steel drums and grouted with concrete before disposal (IAEA 2009e; IAEA 2011a; Sweden $20105^{\text {th }}$; Sweden 2008).



Figure 52. Shallow land burial at Oskarshamn (Sweden 2008)

\section{Current and Future Initiatives}

Major facilities that remain to be constructed and licensed include a repository for waste from decommissioning and dismantling the nuclear power plants and a repository for long-lived low and intermediate level waste.

There is currently no national policy requiring a certain starting point or endpoint for decommissioning. When the dismantling will start is a decision to be made by the owner of the NPP and it is their responsibility to plan and to execute the decommissioning activities. To meet the future needs for disposal of decommissioning waste resulting from the nation's NPPs, the existing SFR-1 facility at Forsmark will be extended. The planned extension (SFR-3) tunnel system layout is illustrated in Figure 51. The extension will be built at the same depth as the existing facility (i.e. $50 \mathrm{~m}$ ) and is designed with a total capacity of $150,000 \mathrm{~m}^{3}$, to handle the entire volume of estimated LILW from decommissioning and dismantling activities from the 12 Swedish NPPS. Test drilling in preparation for the extension was performed in 2009, and the results are currently under review and analysis. The goal is to submit a permit application for the extension in 2013, with the planned start of operation in 2020, at the earliest (SKB 2011a; Carlsson 2007; SKB 2009).

Long-lived LILW, mainly material from research, industry, medical applications, core components, and internal reactor components that were close to the core, is currently placed in interim storage either at the NPPs or Studsvik site, or in storage pools at the interim storage for spent nuclear fuel (Clab). A repository for approximately $20,000 \mathrm{~m}^{3}$ of this type of waste is eventually planned for the SFR facility. Its design would be similar to current SFR-1, but built at greater depth $(200$ to $300 \mathrm{~m})$. The final repository for long-lived LILW is estimated to be sited in about 2035 and operational around the year 2045 (Carlsson 2007; IAEA 2011a; OECD-NEA 
2009b; Sweden 2008). In the interim, preparations are under way for dry storage of long-lived LILW from all nuclear power plants in the Rock Cavern for Waste (BFA) in Simpevarp. A new type of waste container specially designed for this type of storage is under development. The Orskarshamn facility is already licensed and using BFA for storage of their long-lived LILW. Transports of long-lived waste from interim storage buildings at the other two NPP's are planned to start in 2011 to 2012, provided that an updated safety report has been approved by the regulatory authorities (OECD-NEA 2009b; Sweden 2008).

\subsection{Ukraine}

\section{Nuclear Capabilities}

The Ukrainian nuclear industry began in the early 1970s and was closely involved with Russia and the nuclear infrastructure of the Soviet Union, in order to ensure the military defense of the country. In fact, a significant part of the Soviet Union's technical and scientific nuclear complex was based in the Ukraine. Following the collapse of the Soviet Union, even though the Ukraine returned all nuclear weapons and delivery systems back to Russia, they inherited a sizeable nuclear infrastructure that has remained relatively stable (WNA 2011t; IAEA 2009f).

The Ukraine's first and best-known nuclear power plant was Chernobyl (ChNPP), which went critical in 1977. Chernobyl's had four operating reactor's during it lifetime: unit 4 was destroyed in the 1986 accident; unit 2 was shut down after a turbine hall fire in 1991; unit 1 was closed in 1997; and unit 3 was closed at the end of 2000 due to international pressure. Today, the Ukraine is heavily dependent on nuclear energy, with 15 operating reactors and two more under construction at four sites, generating nearly half of the country's electricity. In addition, there are two operating research reactors (WNA 2011t; IAEA 2009f).

Interruptions in Ukraine's natural gas supply from Russia in January 2006 sharply focused attention on the role of domestic nuclear power for greater energy security. In addition, the government intends to maintain its nearly 50 percent nuclear share in electricity production to 2030. To achieve these plans and enhance Ukraine's energy independence, a nuclear power strategy was approved by the government in 2006 that includes the building and commissioning 11 new reactors and 9 replacement units to more than double nuclear capacity by 2030 (WNA 2011t).

\section{Regulation and Legislation}

As a supreme governing body, the Cabinet of Ministers of Ukraine is delegated with powers to implement the laws of Ukraine referring to fuel and energy, approve energy policy and terms of public energy assets management, and develop a management system. In the second part of 1991, the breakdown of the Soviet Union deeply affected the structure of the nuclear energy complex, resulting in the separation of its various enterprises and loss of the centralized management system. As a result of that situation, the Cabinet of the Minister initially made the NPP managers personally responsible for the plants safe operation. In order to create a State Management System, ensuring the safe operation of the nuclear energy sector, the Cabinet of Ministers established the Ukrainian State Committee on Nuclear Power Utilization (GOSKOMATOM) in 1993. In 1996, the then Goskomatom was replaced by two Departments within the Fuel \& Energy Ministry: a Department for Nuclear Energy, responsible for civil nuclear power plants operation, and a Department for Atomic Industry, responsible for the development 
of nuclear fuel cycle. The state enterprise National Nuclear Energy Generating Company (NNEGC) "Energoatom" was also set up in 1996 as the organization of all operating NPP units in Ukraine with the aim of improving the electricity supply for the population and to the national economy, improving the NPPs operation, increasing the competition ability under various market conditions, and modifying the structure of nuclear energy management in accordance to the requirements of the acting legislation. The State Nuclear Regulatory Committee of Ukraine (SNRCU), established in 2000 by Presidential Decree, is currently the main central executive body authorized to regulate nuclear and radiation safety in Ukraine. The SNRCU, as a regulatory body, is independent from institutions and organizations that conduct their activity in the area of nuclear energy use (WNA 2011t; IAEA 2009f; Purtov et al. 2007).

Current nuclear and radiation requirements and regulatory provisions are set in a number of the laws of Ukraine, legal acts of the Cabinet of Ministry of Ukraine, and legal acts of the central executive authorities (e.g., norms, codes, and standards) (IAEA 2009f; SNRCU 2009; SNRCU 2007). The Law of Ukraine entitled On Nuclear Energy Use and Radiation Safety (1995) established the basis law in the field of nuclear energy utilization, which included determining the fundamentals of state regulation, defining the basic principles of the state policy, and identifying a provision giving an operating plant full legal responsibility for the consequences of any accident. In general, the law aims to protect the people and environment against adverse effects of nuclear activities and radioactive waste at present and in future. The 1995 law on Radioactive Waste Management complements this, and established the Ministry of Chernobyl Affairs (now a part of the Ministry for Emergency Situations) as the state agency responsible for licensing storage of radioactive waste. Finally, in 2009, the Strategy for Radwaste Management in Ukraine was approved. The Strategy, which is developed for 50 years, identified the mechanism for financing the handling of radioactive materials. The State Fund of Radioactive Waste Management is paid into by all enterprises and organizations in the territory of Ukraine whose activities result or may result in radioactive waste. In return, the state guaranties that they will ensure further safe management of generated radioactive waste, including its disposal (WNA 2011t; NTI 2008; SNRCU 2007; SNRCU 2009).

\section{Waste Management Practices and Facilities}

As in many other countries, the main sources of radioactive waste include industrial applications, research reactors, NNP operation, and planned decommissioning of NPPs. In addition, a unique Ukrainian situation involves the management of radioactive waste from the Chernobyl exclusion zone (Kozulko 2007). As a result, the Ukraine has numerous facilities for managing and storing LILW generated within the country, including: six State Interregional Specialized Plants (SISPs) for the non-nuclear power sector, two research reactor sites, four operating NPP sites, and the Chernobyl NPP and exclusion zone (IAEA 2009f; SNRCU 2009; SNRCU 2008)

The state interregional specialized plants (SISPs), of the State Corporation Ukrainian State Radon Association UkrDO (UkrDO Radon), deal with management of LILW generated from the use of radiation sources by non-nuclear power sector enterprises (e.g., industrial, medical, scientific, education). Originally established in the early 1960s, there are currently five operating SISPs that provide both management and long-term storage: Kyiv, Odessa, Kharkiv, Dnipropetrovsk, Lviv, and Donetsk. In general, after transport to the SISP, shielded radiation sources are stored in solid radioactive waste storage facilities and unshielded sources are stored in specialized well-type storage facilities designed for such radiation sources. Stores for solid LILW are engineered structures with dimensions 14.5 by 9.5 by $3 \mathrm{~m}$ and volume of $400 \mathrm{~m}^{3}$. The specialized plants do not accept liquid LILW; waste is accepted only after solidification and 
stored as solid radioactive waste. The liquid LILW produced by the SISPs is stored in the dedicated cylindrical tanks (dimensions 9 by $3.15 \mathrm{~m}$ ) made of stainless steel and coated with reinforced concrete. All plants also operate laundries and decontamination services for work clothes and means of individual protection. Depending on the specific plant, solid LILW storage capacities range from 450 to nearly $2,400 \mathrm{~m}^{3}$, with 2007 volumes ranging from about 400 to nearly $2000 \mathrm{~m}^{3}$ and totally nearly $4,900 \mathrm{~m}^{3}$ across all five pants. For Liquid LILW, storage capacities range from 200 to $4,000 \mathrm{~m}^{3}$, with 2007 volumes ranging from almost 30 to more than $400 \mathrm{~m}^{3}$ and totaling approximately $650 \mathrm{~m}^{3}$. A sixth SISP, Donetsk, does not operate storage facilities; it merely collects LILW in the region and performs decontamination services (SNRCU 2009; SNRCU 2008; Kozulko 2007; IAEA 2006d; SNRCU 2005).

Management of radioactive waste from Ukraine's two research reactors, SUNEI (Sevastopol) and NASU INR (Kyiv), occurs at the source of generation. Solid LILW is collected in situ, sorted, accounted for, and temporary stored in the facilities on-site until transported to the central waste management facility (i.e., Odessa or Kyiv SISP). Liquid LILW is collected via a special underground sewerage system located and temporary storage in metal tanks. At the SUNEI facility, the waste is then typically diluted up to the existing discharge standards and released into the sewer. Liquid LILW from NASU INR is processing by using evaporation followed by cementation (SNRCU 2008; Kozulko 2007).

Management of operational LILW is performed at the sites of four existing NPPs: Zaporizhzhya (ZNPP), Rivne (RNPP), South Ukraine (SUNPP), and Khmelnitsky (KNPP). The LILW primarily results from daily operation and scheduled repairs of the nuclear reactor units. The NPP designs provide for radioactive waste management systems and facilities, which include: solid waste sorting and compacting, incineration, liquid evaporation, and temporary storage. For solid radioactive waste, reinforced concrete boxes are used for storage purposes. For liquid waste, treatment involves purification, to both minimize volumes and reuse treated water, followed by evaporation. As of 2009 , the NPP storage facilities house a total of about $37,000 \mathrm{~m}^{3}$ of solid and $13,000 \mathrm{~m}^{3}$ of liquid radioactive waste, with more than 99 percent falling within the LILW category (94 to 99 percent LLW and 1 to 5 percent ILW, depending on facility). In general, the storage capacity at each NPP is calculated on the basis of design a 30-year service life of a power Unit (SNRCU 2009; SNRCU 2008; IAEA 2006d; SNRCU 2005)

LILW accumulated during the operation of the ChNPP is stored in temporary facilities on-site, which were constructed according to the original ChNPP designs. Storage facilities are equipped with special protection systems, including: ventilation, sewerage, physical protection, radiation control, alarm, and perimeter ground water monitoring. At present, the modules of storage are closed down (SNRCU 2008). In 2009, an Industrial Complex for Radwaste Management (ICSRM) was constructed at the ChNPP site to manage LILW. This complex incorporates facilities for temporary storage of solid and liquid HLW and LILW contained in 200$L$ drums; retrieval and processing of solid LILW from the existing temporary storage; sorting of long-lived and HLW solid waste for temporary separate storage; and conditioning of solid LILW by incineration, high-force compaction, and cementation, as required, before packaging it in cemented concrete containers for disposal (WNA 2011t; SNRCU 2008; Purtov et al. 2007; IAEA 2006d; SNRCU 2005).

The total volume of radioactive waste resulting from the Chernobyl disaster has been estimated to be approximately 2.8 million $\mathrm{m}^{3}$, which is located in radioactive waste disposal sites (RWDS), radioactive waste interim confinement sites (RICS), and more than 800 points of temporary localization that were established in the exclusion area in 1986 under extreme post-accident conditions and do not meet current regulatory requirements. The land of the Chernobyl 
exclusion zone has been withdrawn from national economy use and the total amount of LILW accumulated in the zone constitutes approximately 11 million $\mathrm{m}^{3}$, which includes 1.2 million $\mathrm{m}^{3}$ of radioactive contaminated forest (SNRCU 2003). Management of the radioactive waste generated as a result of works related to the elimination of consequences from Chernobyl accident, rehabilitation of exclusion zone, and decommissioning of ChNPP power units is performed by the State Specialized Enterprise (SSE) Complex and Technocenter (SNRCU 2009; SNRCU 2008; IAEA 2006d).

The SSE Complex implements radioactive waste management activities in the exclusion zone, including the collection and transportion of radioactive waste and operation of the last active and functioning RWDS, referred to as Buryakivka, a near-surface trench-type disposal site. Buryakivka RWDS opened in 1987 with a total design capacity of approximately 600,000 to $690,000 \mathrm{~m}^{3}$, which is situated within a total of 30 trenches (each designed to store about $22,000 \mathrm{~m}^{3}$ ). As of the end of 2009 , more than $600,000 \mathrm{~m}^{3}$ of LILW had been disposed of at the facility, leaving only about 7 to 11 percent of the design capacity remaining. Thus, the SSE Complex plans to modernize the Buryakivka RWDS to create additional capacities to dispose LLW generated at ChNPP and in the exclusion area, after performing an operational and longterm safety reassessment that takes into account all the radioactive waste disposed (or planned to be disposed) and state of existing protective barriers. In additional, the SSE Complex monitors and performs routine safety activities at the inactive RWDS and RICS sites (SNRCU 2009; SNRCU 2005).

The SSE Technocenter is responsible for and performs construction and operational activities related to the complex for decontamination, transport, processing, and disposal of radioactive waste from the territories contaminated as a result of the ChNPP disaster (code name Vektor) and required infrastructure facilities. The current Vektor Complex disposal facilities, which are

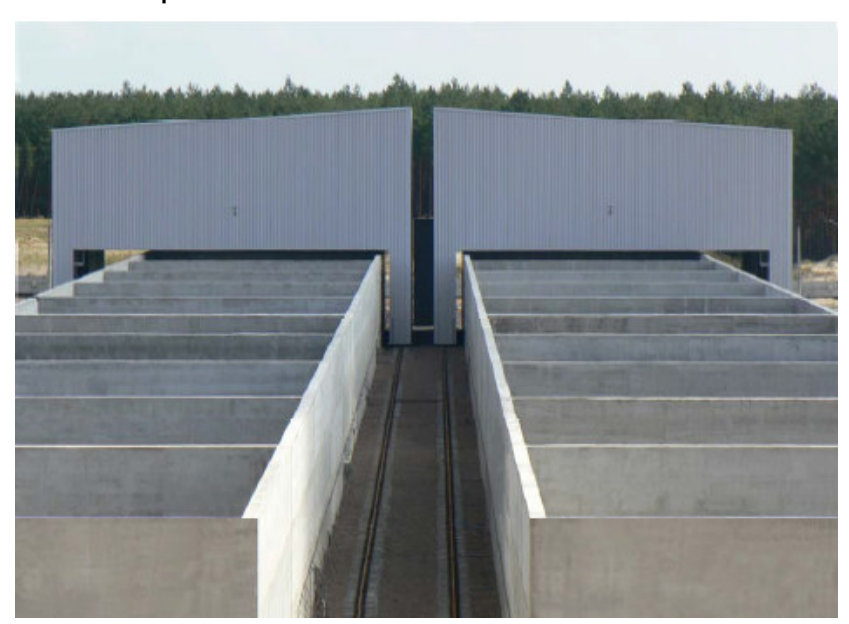

Figure 53. ENSDF at the Vektor Complex in the Chernobyl exclusion zone (NUKEM 2010) located about $10 \mathrm{~km}$ away from the ICSRM, are intended for short-lived LILW resulting from the Chornobyl disaster. These facilities include an engineered near-surface disposal facility (ENSDF), completed in 2008 as part of the ICSRM project and licensed in 2009 for disposal of conditioned solid LILW from the ICSRM and other sources of within the Chernobyl exclusion zone. The primary functions of the ENSDF are to receive, monitor, and record waste packages; load the waste packages into concrete disposal units; enable capping and closure of the disposal units; and allow monitoring and control for 300 years following closure. This facility, shown in Figure 53, is of modular structure with a mobile containment framework and remote lifting cranes for waste package handling and control. Each of the two sections consists of eleven modular disposal units with dimensions of about 25 by $20 \mathrm{~m}$, built on a layer of materials (gravel, cement, concrete) which provides an underground waterproofing system isolating the facility from the water table. The ENSDF has a capacity of approximately $55,000 \mathrm{~m}^{3}$ of waste packages. Reinforced concrete waste packages are placed on the perimeter and $200-\mathrm{L}$ drums are located in the center part of the disposal units. After the first layer is filled, it is capped with mortar, and once a disposal unit is full to depth of four SWPF waste containers (256 in total) and seven drums $(3,185$ in total) the upper layer will also be capped with a mortar layer. The unit 
will then be temporarily capped with a $0.6 \mathrm{~m}$ thick reinforced concrete slab covered with bitumen and a polyurethane film, and the mobile framework will be moved to the next disposal unit. The general loading and capping process is illustrated in Figure 54. At closure, when all disposal units of both sections are full, a final cover of layered engineered and natural barriers, including sand, bitumen, clay, gravel, and vegetation, will be put in place (NUKEM 2010; Ziehm and Pichurin 2003). The Vektor Complex also has disposal repositories TRO-1 and TRO-2, for LILW contained in reinforced concrete containers and bulk, respectively (SNRCU 2009; SNRCU 2008).

\section{Current and Future Initiatives}

The Vektor Complex disposal facilities were planned in two stages. Stage I facilities, as described above, were completed in 2008. The Stage II is to include facilities for: processing LILW (including long-lived); disposal of short-lived LILW from the Chernobyl site and other Ukrainian NPPs; disposal or long-term storage non-nuclear power enterprise waste; processing and long-term storage of long-lived and HLW (including nuclear fuel processing waste and

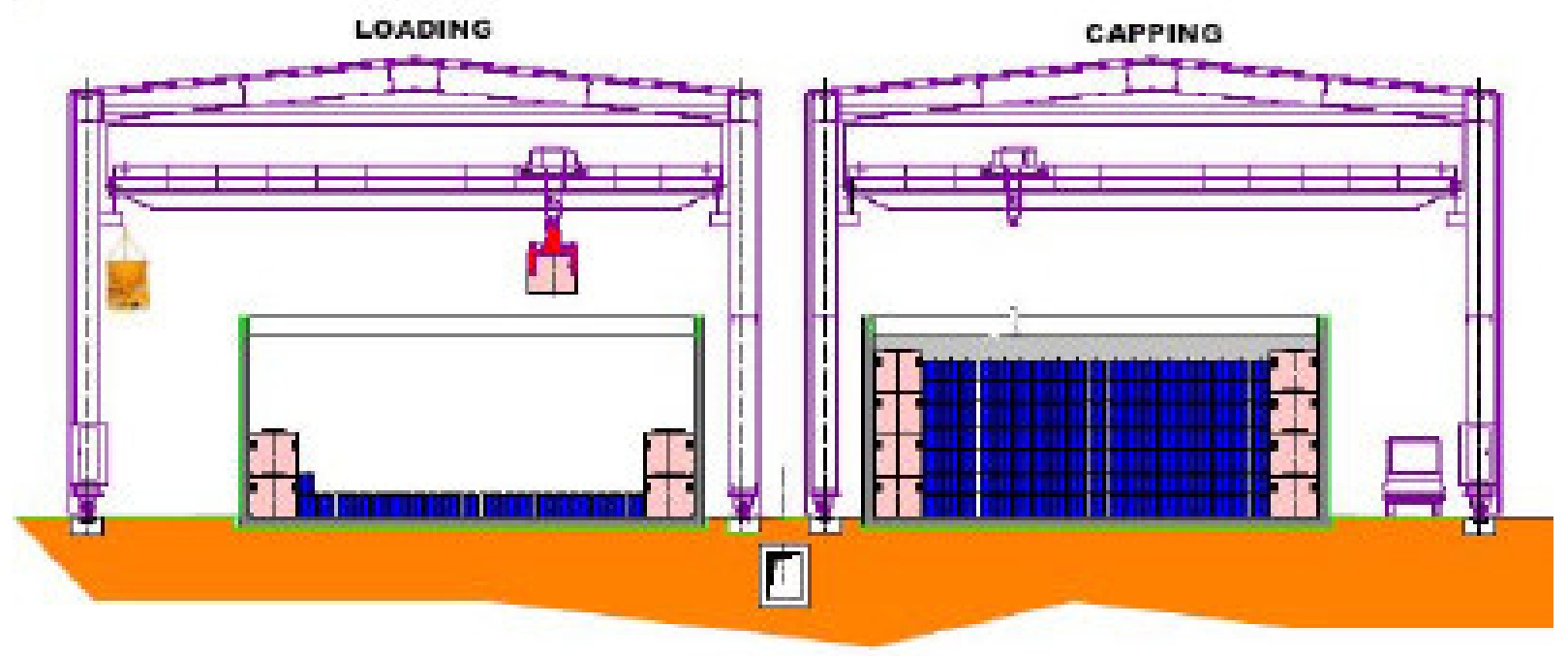

Figure 54. General storage procedure at the ENSDF (NUKEM 2010)

spent radiation sources). As of the end of 2009, the Cabinet of Ministers of Ukraine had endorsed the feasibility study of Stage II (SNRCU 2009).

The top-priority initiatives for the operational management of NPP waste include: modernization of existing and construction of new processing facilities for solid and liquid radioactive waste at the NPP sites; efforts to be taken at the existing NPPs to remove the accumulated radioactive waste from temporary storage facilities for processing; improvement of existing radioactive waste transportation systems; and improvement and development of special vessels for radioactive waste collection, transportation, and storage (IAEA 2009f).

\subsection{United Kingdom}

\section{Nuclear Capabilities}

British scientists were preeminent in the development of nuclear energy through to the early 1940s, and then picked up again after the Second World War focusing mainly on defense- 
related applications. The UK's civil nuclear program began in 1953, and the world's first commercial-scale nuclear power reactor started up in the England in 1956 at the Sellafield munitions and nuclear facility site. In the 1990's, nuclear plans were basically abandoned when the Secretary of State for Energy also announced that there was to be a moratorium on public sector construction of new nuclear stations. Since then, the question of new nuclear build was effectively ruled out until 2006, when a review of energy policy reversed the government's opposition to new nuclear. Government policy in England and Wales has since been supportive of new nuclear plants, which should be initiated, financed, constructed, and operated by the private sector with internalized waste and decommissioning costs as per international industry norms. The Scottish Government, on the other hand, has stated that new nuclear power is not wanted or needed in Scotland. This effectively means that no new nuclear plants are likely to be built in Scotland. In fact, the Scottish Government's energy policy aims "to progressively increase the generation of renewable and clean energy, [and] migrate Scotland away from a dependence on nuclear energy." However, Scottish Ministers are supportive of the possible life extension of existing nuclear power stations in the short term to help security of supply (WNA 2011r; WNA 2011s; DECC 2010; IAEA 2006e)

Currently, the UK has 18 operating nuclear power reactors at nine sites currently generating about 20 percent of its electricity, which is down from 25 percent in the late 1990s as old plants have been shut down and ageing-related problems affect plant availability. In fact, three reactors are due to shut down by the end of 2012 and all but one is scheduled to be retired by 2023. As a result, planning has begun on the first of the next-generation plants, which are expected to be on line beginning around 2018, with 10 to 12 additional new reactors operations by 2025. The UK also has 3 operating research reactors. (WNA 2011r; WNA 2011s; DECC 2010; IAEA 2007)

\section{Regulation and Legislation}

The Nuclear Installations Inspectorate (NII) was established in 1960 by the Nuclear Installations Act 1959 (subsequently replaced by the Nuclear Installations Act 1965) with the responsibility and power for regulating the nuclear industry. In 1975, the NII was incorporated into Health and Safety Executive (HSE), which was established in 1974 to enforce legislation on health and safety at work, particularly related to nuclear installations and site licensing procedures. The $\mathrm{NII}$, on behalf of the HSE, has the power to attach conditions to a nuclear site license that appear necessary or desirable in the interest of safety, or it views to fit with respect to the handling, treatment, and disposal of nuclear matter. The NNI, along with the Office for Civil Nuclear Safety (OCNS) and the UK Safeguards Office (UKSO) incorporated in 2007, is part of the HSE's the Nuclear Directorate (ND). The ND is a non-departmental public body funded through HSE and sponsored in Parliament by the Department for Work and Pensions (DWP). The HSE, and thus the ND, have the authority, under the Nuclear Installations Act of 1965, to charge the cost of effort and related expenses for regulatory work performed in support of the licensing process to the individual nuclear licensees (OECD-NEA 2010d; DECC 2010).

The policy for the management of radioactive waste is decentralized in the UK. The UK Government is responsible for policy in England, while the Scottish, Welsh, and Northern Ireland Governments (referred to as Devolved Administrations) have responsibility for policy in their respective countries. In England and Wales, the Environment Agency was created by the Environmental Act of 1995 to provide the basis for regulatory framework related to environmental protection and improvement, including the regulation of radioactive waste disposal. It is a non-departmental public body, sponsored largely by the UK Department for Environment, Food and Rural Affairs (Defra) and Welsh Assembly Government (WAG). The 
equivalent organization in Scotland is the Scottish Environmental Protection Agency (SEPA), also established by the Environmental Act of 1995 and sponsored by the Scottish Government; in Northern Ireland it is the Department of the Environment, Environment and Heritage Service (DOE EHS) (OECD-NEA 2010d; DECC 2010).

The Nuclear Decommissioning Authority (NDA), established by the UK Government in 2005, is responsible for civil and public sector nuclear facilities, as well as the long-term management of the country's historic and committed nuclear liabilities. The ownership of some twenty sites was transferred to the NDA with the previous owners, as contractors, now responsible for the management and operation of those sites. In addition, the NDA is tasked with the development of a national solid LLW strategy from the nuclear industry in the UK. In March 2007, the UK government and Devolved Administrations published a new UK policy for managing solid LLW, which outline the priorities for managing LLW responsibly and safely. As a result, the NDA drafted and initiated a consultation on the strategy for the Management of Solid Low Level Radioactive Waste from the UK Nuclear Industry. This plan, which based on a risk-informed approach, provides strategies for continued capability and capacity in the UK for safe, secure, and environmentally responsible management and disposal of LLW, originating from both nuclear and non-nuclear power industries. These strategies include the optimal use of the country's existing repository (described in greater detail in the next section below), development and use of new management and disposal routes, and assessment of when a future replacement facility might be required (OECD-NEA 2010d; Booth 2007; IAEA 2006e).

Radioactive waste in the UK is broadly classified into categories according to its heat generating capacity and the nature and quantity of radioactivity. HLW, or heat-generating, is considered that in which the temperature may rise significantly as a result of its radioactivity. ILW has activity levels exceeding the upper boundaries for LLW, but is not considered heat-generating. LLW is generally defined as having a radioactive content not exceeding $4,000 \mathrm{~Bq} / \mathrm{g}$ of alpha or $12,000 \mathrm{~Bq} / \mathrm{g}$ of beta/gamma activity; but, specific disposal sites may have different criteria. VLLW is considered a sub-category of LLW and is further split into 2 groups: low and high volume. In the case of low volume VLLW, arising from, for example, hospitals and universities, criteria for municipal, commercial, or industrial disposal alongside ordinary refuse (so-called "dust-bin disposal) include a maximum total activity of $400,000 \mathrm{~Bq}$ or single item activity of $40,000 \mathrm{~Bq}$ per $0.1 \mathrm{~m}^{3}$ of waste. High volume VLLW, arising from, for example, nuclear decommissioning, includes waste with a maximum concentration of $4 \mathrm{~Bq} / \mathrm{g}$ of total activity, which must be disposed of at controlled landfill sites (OECD-NEA 2010d; Pöyry 2011).

\section{Waste Management Practices and Facilities}

Most of the radioactive waste in the UK originates from the civil nuclear power industry, including the manufacture of fuel, reactor operations, decommissioning, spent fuel reprocessing, and $R \& D$ activities. The remainder of the radioactive waste arises from the defense program (i.e. nuclear weapons and submarines) or private sector applications (i.e., medical, industrial, educational, and research). In addition, the UK has a large amount of legacy waste from the pioneering development of nuclear power (WNA 2011r; OCED-NEA 2010, UK-P). According to the 2010 UK Radioactive Waste Inventory, an estimated total of more than 5.2 million $\mathrm{m}^{3}$ of radioactive waste existed (as of the beginning of April 2010) or was predicted to arise from existing facilities to end of life. Of this volume, approximately 4.5 million $\mathrm{m}^{3}$ is categorized as LLW and nearly 0.5 million $\mathrm{m}^{3}$ as ILW (Pöyry 2011). 
Until 1983, an estimated $33,000 \mathrm{~m}^{3}$ of radioactive wastes were disposed of in deep ocean sites along the coast of the UK and in the North Atlantic. In 1993, the government officially accepted an international ban on this method of disposal (WNA 2011r; Pöyry 2011). Today, the UK operates only one national LLW disposal facility, the Low Level Waste Repository (LLWR). The LLWR, pictured in Figure 55, is a 300 acre (120 ha) near-surface facility located near the village of Drigg in Cumbria, $6 \mathrm{~km}$ south of the Sellafield site. Originally the site was used for the production of explosives, but it was transferred to the United Kingdom Atomic Energy Authority (UKAEA) in 1957 for development as a low level waste repository. British Nuclear Fuels plc (BNFL), a company owned by the UK Government, took over ownership of the site in 1971, but ownership was transferred to the NDA in April 2005. The LLWR has operated since 1959 and is currently run by LLW Repository Ltd. on behalf of the NDA. The national repository site has

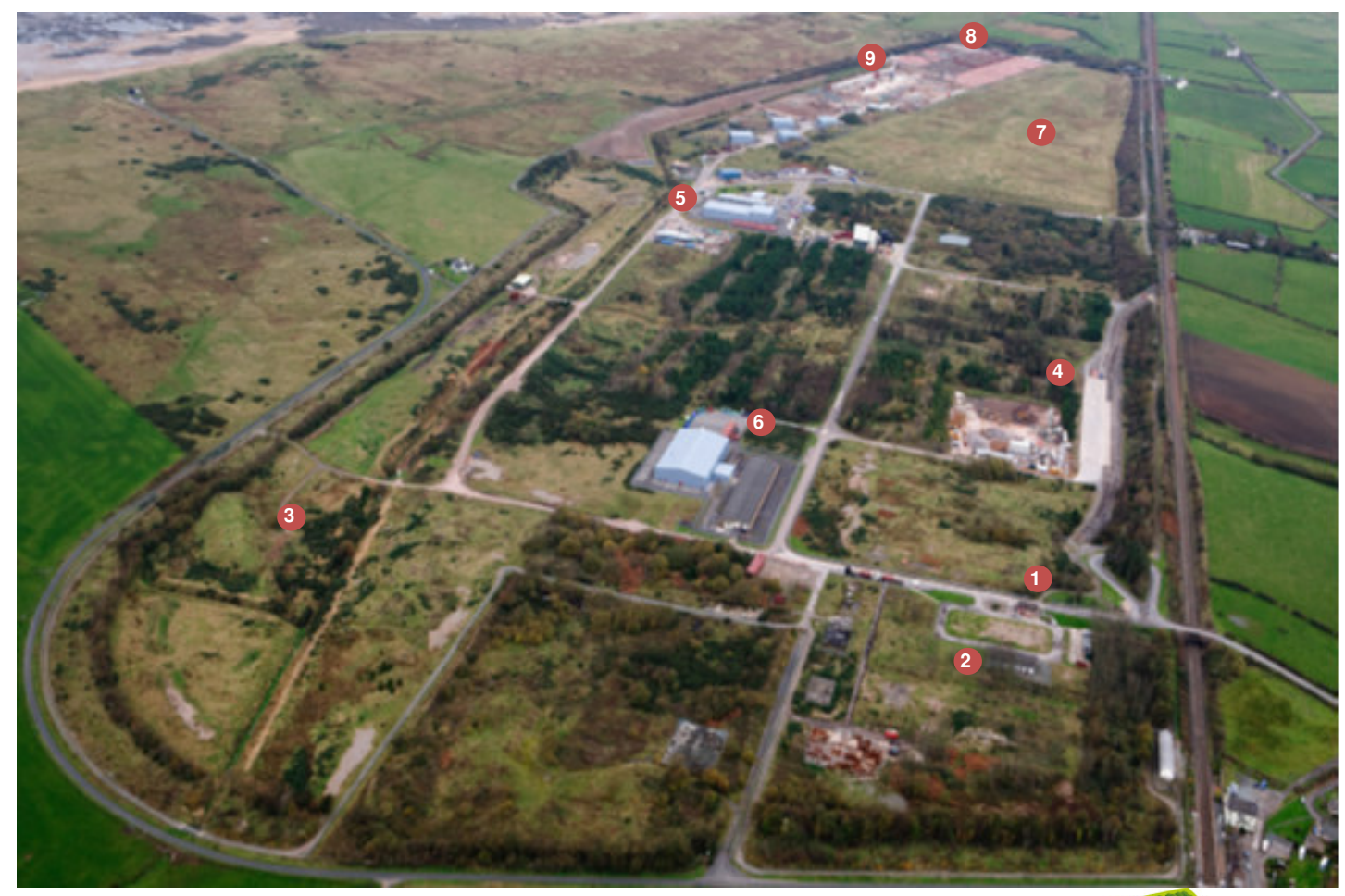

1. Site entrance

2. Conference centre

3. Wildlife habitat

4. Rail sidings

5. Office complex

6. Grouting facility

7. Trenches 1-7

8. Vault 8

9. Vault 9

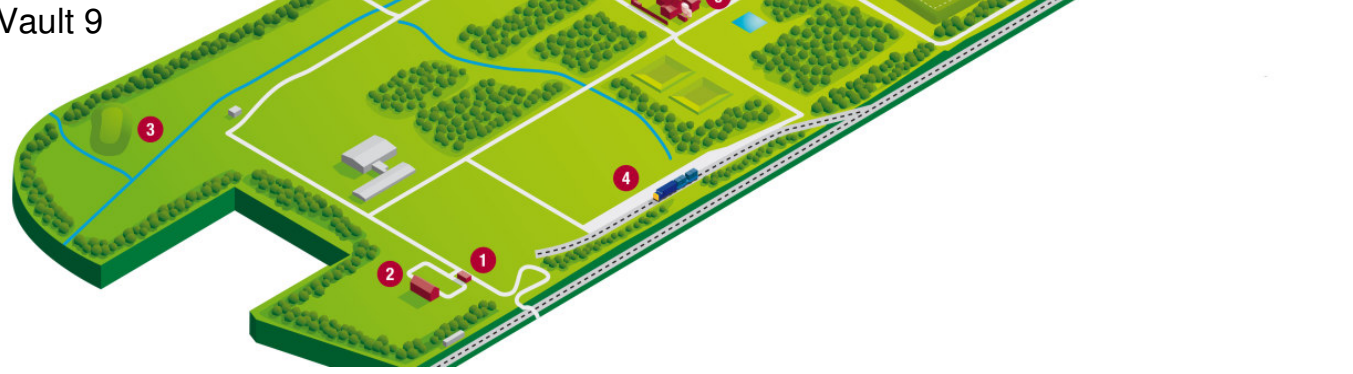

Figure 55. Drigg LLWR site layout (LLWR 2011) 
been operated safely for over 50 years and has evolved in line with international best practice (Pöyry 2011; WNA 2011w; Booth 2007).

LLWR is used by non-nuclear power sector facilities, such as hospitals and universities, for the disposal of their radioactive wastes, as well as for the disposal of LLW generated on nuclear sites. All disposals are authorized by the UK's Environment Agency and must not exceed LLW activity levels (i.e., $4,000 \mathrm{~Bq} / \mathrm{g}$ of alpha or $12,000 \mathrm{~Bq} / \mathrm{g}$ of beta/gamma). In addition, at a local level, the Cumbria Minerals and Waste Development Framework (MWDF) Core Strategy requires that in order for the LLWR to continue fulfilling its role as a component of the UK's LLW management capability, proposals for very long term storage or disposal must demonstrate feasibility in respect of the long term integrity of the site in terms of sea level rise and coastal erosion, and within the radiological capacity of the site. Thus, the MWDF provides further policy support for the full extent of the proposed site optimization and closure works, thereby enabling implementation of the UK national level Strategy aims and objectives (Booth 2007; LLWR 2011; DECC 2008).

During the years from 1959 to 1995, about $800,000 \mathrm{~m}^{3}$ of solid LLW was deposited into a series of open clay-lined trenches, which were then covered with soil and an interim cap. Since about 1988, trench disposals have been phased out in favor emplacement in concrete vaults. In 1995, the LLWR received a major upgrade of its disposal operations, after which all LLW has been and is currently disposed of in concrete engineered vaults (dimensions 60 by 200 by $5 \mathrm{~m}$ ). An engineered clay base is located beneath the concrete floor slab along with a drainage layer to remove water. Waste, which is typically comprises paper, cardboard, plastic, protective clothing, soil, rubble and metal, is

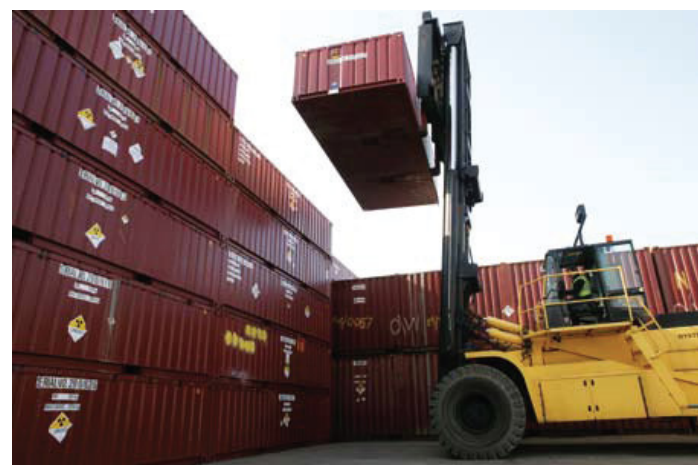

Figure 56. Metal LLW containers used at the Drigg LLWR (LLWR 2011) transported to the site by both road and rail. Where possible, the waste is compacted and then grouted into steel containers (typically $20 \mathrm{~m}^{3}$ ), similar to shipping containers, as pictured in Figure 56, prior to emplacement within the vaults. Larger items of wastes are grouted directly, in situ in the vault. As of April 2010, the deposited waste occupied 200,000 $\mathrm{m}^{3}$ of vault space, with more than $36,000 \mathrm{~m}^{3}$ of LLW in temporary storage awaiting disposal.

At final closure, void space within the vaults is backfilled with grout and a 12 component layered cap (shown in Figure 57), consistent with international best practice for LLW repositories and hazardous waste sites, will be installed. The cap must provide a suitable long term landscaped landform and physical cover over both the trenches and vaults, but also allow degradation gas to vent to atmosphere in order to prevent pressure build up that may adversely affect the integrity of the overlying cap formation layers. Finally, an enhanced engineered drainage system is planned within the disposal area to capture any ingress of water and conduct any resulting leachate via a preferred pathway (Booth 2007; LLWR 2011; Pöyry 2011; DECC 2008; IAEA 2001a). 


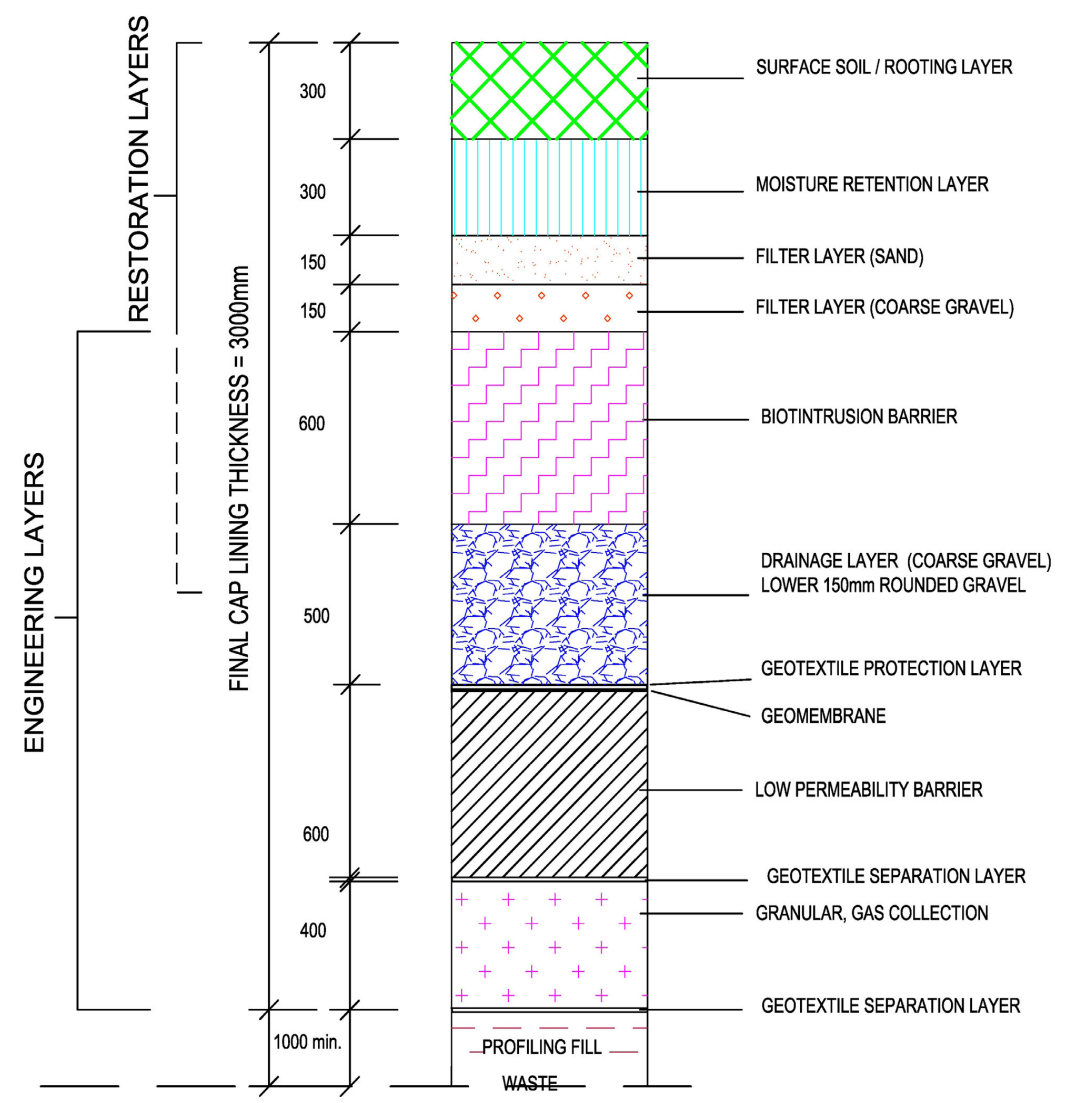

\section{SECTION THROUGH FINAL CAP}

Figure 57. 12 component layered cap for the LLWR (LLWR 2011)

LLW is also disposed of at various nuclear facilities across the country. For example, the Calder Landfill Extension Segregated Area is an engineered landfill on site at Sellafield used to dispose of high volume low-level radioactive waste primarily consisting of soil and rubble from demolition and construction projects, with a small amount of organic waste. The Clifton Marsh landfill site, near Preston, Lancashire, provides LLW land filling for three nuclear facility sites (Springfields Fuels Ltd; Sellafield Ltd [for Capenhurst]; and Urenco UK Ltd) and receives household and industrial waste from the Preston area (DECC 2008).

In Scotland, LLW is disposed of at the Dounreay site in Caithness, which was Britain's centre for experimental fast breeder research and development from 1954 until 1994. The site is currently operated and managed by Dounreay Site Restoration Ltd (DSRL) under contract to the NDA. The on-site LLW surface disposal facility, which only accepted waste generated from the Dounreay site, consisted of a series of six shallow pits. The now full facility was closed in 2005 with a disposal volume of almost $34,000 \mathrm{~m}^{3}$ (Pöyry 2011). As of April 2010, an additional 9,400 $\mathrm{m}^{3}$ of LLW was being temporarily stored awaiting the opening of a new disposal facility. There is also some LLW stored in existing pits which may have to be retrieved and disposed of in a suitable facility (Booth 2007; Pöyry 2011; DECC 2008).

With respect to ILW in the UK, until a long-term management solution is available, waste is conditioned into a passively-safe form and packaged for interim storage. The conditioning is intended to secure the wastes long-term safety, potentially for several decades, without the 
need for complex safety systems and to avoid the costs and risks involved in repackaging. As of April 2010 , nearly $170,000 \mathrm{~m}^{3}$ of ILW was being held in interim storage in specially built facilities at each site where it is produced. The Sellafield nuclear site holds the single largest inventory of ILW, approximately two-thirds of the total, in the UK. Other sites include nuclear power stations of the Magnox design (still operational at two sites; shutdown at 11 sites) the nuclear research sites at Donnreay, Harwell, and Winfrith, and the Atomic Weapons Establishments at Aldermaston (Pöyry 2011; OECD-NEA 2010c; DECC 2008).

The authorized disposal of solid ILW took place, primarily between the years of 1959 and 1977, at Dounreay within a shaft that was excavated to remove soil during the construction of a subsea effluent discharge tunnel. As a consequence of improved disposal practices, coupled with the shafts close proximity to the sea, UKAEA intends to recover the contents of the $65 \mathrm{~m}$ deep shaft for repackaging for long term interim storage and future disposal (Booth 2007; DECC 2008). Also in the 1960s, as the shaft filled up, a purpose-built storage facility known as the silo was constructed for ILW, with the first deposits occurring in 1971, after which the shaft was used only for bulky items. A second silo was built in the 1980s but never used. Transfers to the silo ceased in the 1990s, since when ILW has been stored in drums above-ground awaiting final disposal (DSRL 2011).

\section{Current and Future Initiatives}

A proposed expansion of the LLWR near Drigg, illustrated in Figure 58, consists of the phased construction of five new vaults (10 through 14), with an identical construction to that of Vault 9. Construction is expected to begin in 2013, and run through 2079 with the closure and capping of Vault 14. In addition, the LLW Repository Ltd., operators of the Drigg LLWR site, is developing a VLLW Disposal Service to support producers of this type of waste.



Figure 58. Proposed LLWR vault expansion (LLWR 2011)

In Scotland, an application has been submitted to the Highland Council for planning permission for a new solid low level waste near-surface disposal facility, adjacent to the eastern corner of the existing Dounreay site as illustrated in Figure 59. The proposed near-surface facility will consist of series of shallow engineered vaults to be built in phases, up to a maximum of six, with multiple barrier caps, as shown in Figure 62. The waste itself will be encapsulated in grout, contained within steel packages, and cemented in place within the vaults. In addition to containerized waste, some items of bulk LLW may be placed directly into the vaults and surrounded by grout in situ. This facility will provide final disposal for up to $175,000 \mathrm{~m}^{3}$ of LLW primarily resulting from decommissioning activities of the Dounreay site and adjacent Vulcan Naval Reactor Test Establishment (NRTE) site, along with relocation of LLW from historical disposal pits. In March 2010, DSRL issued a contract notice for the design and build of the first two vaults. Construction is due to begin in 2012 using a phased approach to enable the development and sizing of vaults tailored to actual waste amounts (DSRL 2011; Crawford 2010; DECC 2008). 
Although there no national facilities for disposal of ILW in the UK, a siting exercise for deep
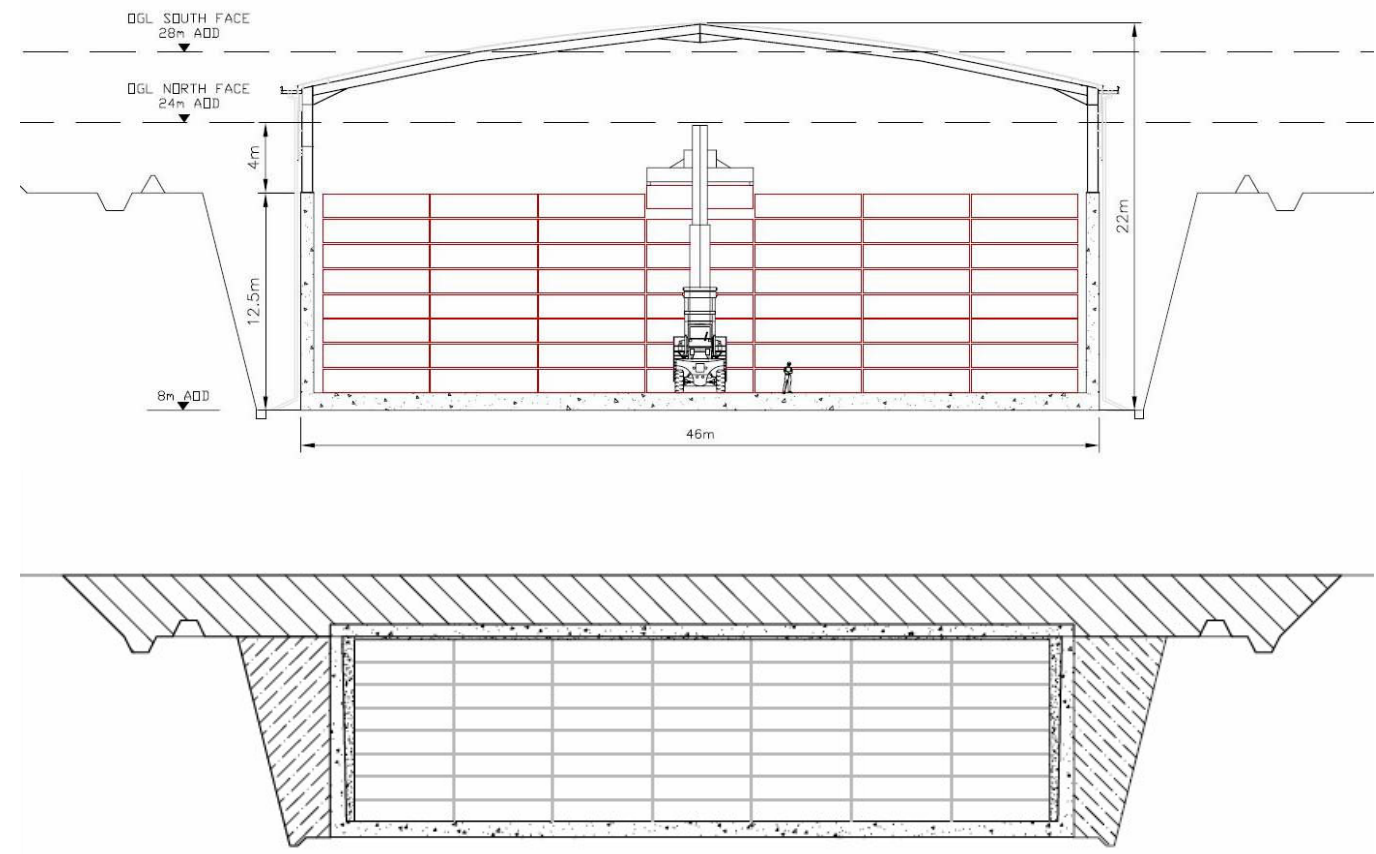

Figure 60. Conceptual diagrams of Dounreay LLW disposal vaults during operation and after closure (Crawford 2010)

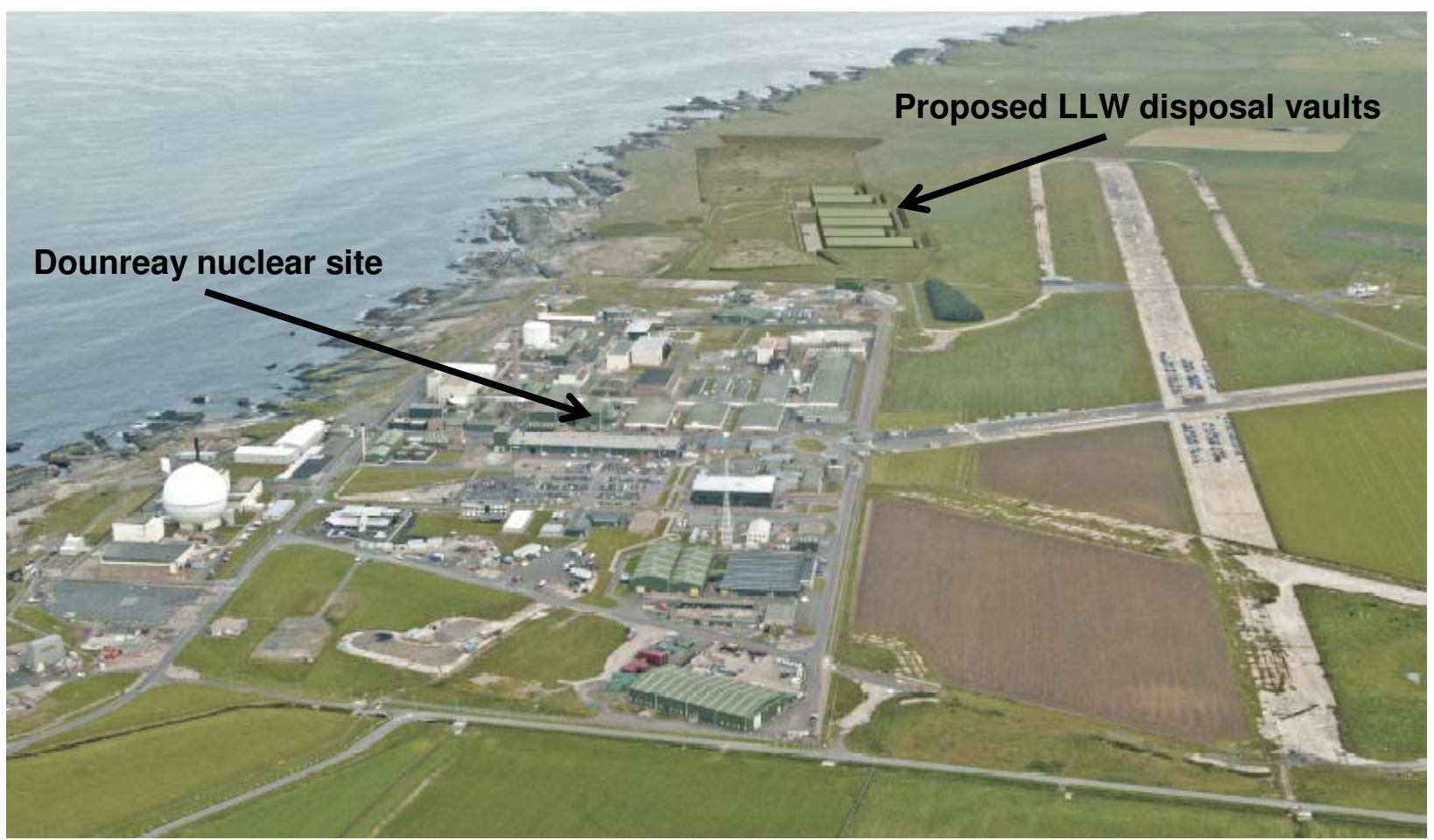

Figure 59. Current Dounreay nuclear site and proposed location of the new LLW disposal facility (Crawford 2010) 
geologic disposal was conducted and eventually rejected during the 1990's. Since then, the NDA has officially set up a Radioactive Waste Management Directorate (RWMD) to develop plans for a deep geological repository for high- and intermediate-level wastes and evolve into the entity that builds and operates it. The government is planning for the Geological Disposal Facility (GDF) to accommodate waste from new build as well as legacy sources (e.g., committed waste from existing operational facilities and those undergoing decommissioning). The new site selection was expected to be in around 2025; however, the government has invited communities to volunteer to host the facility, with three expressions received so far. Next steps include a 4-year geological study, surface research phase lasting ten years, and finally a 15-year period of underground research, construction, and commissioning. Operation is expected to commence as early as 2029 (WNA 2011r; WNA 2011w; Booth 2007).

\subsection{United States of America}

\section{Nuclear Capabilities}

The United States of America (US) was a pioneer of nuclear development. From 1939 to 1945, most research and development was focused on nuclear weapon development, after which attention was shifted to applications for naval propulsion and generating electricity. The first nuclear reactor to produce electricity did so at the National Reactor Testing Station (NRTS) in Idaho in December 1951. Since the mid-1950s, the prime focus has been on the technological evolution of reliable nuclear power plants, when the production of electricity from nuclear power was opened up to private industry. The nation's first full-scale atomic electric power plant, which was the world's first devoted exclusively to peacetime uses, located near Pittsburgh, Pennsylvania (close to the present-day Beaver Valley Nuclear Generating Station on the Ohio River) went online in December 1957 and operated until 1982 (WNA 2011u; WNA 2011z).

Since 1977, there have been no new reactor construction starts, largely because for a number of years gas generation was considered more economically attractive and because construction schedules were frequently extended by opposition, compounded by heightened safety fears following the Three Mile Island accident in 1979. However, during this no-build period, the US reliance on nuclear power continued to grow and remarkable gains in power plant utilization were achieved through improved refueling, maintenance, and safety systems at existing plants. Beginning in 2007, after a more than 30-year period, 16 new license applications have been submitted to build 24 proposed nuclear reactors. It is expected that the first four to six of these new units may come on line by 2020 (WNA 2011u).

Today, the US is the world's largest producer of nuclear power, accounting for more than 30 percent of worldwide nuclear generation of electricity. There are 104 operating nuclear power units in the US, located at 65 sites, in 31 states, operated by about 30 different power companies. In addition, the US has 41 operating research reactors. In 2008, nuclear generated electricity, which was produced primarily by reactors built between 1967 and 1990, accounted for nearly 20 percent of total domestic electricity production (WNA 2011u).

\section{Regulation and Legislation}

The Atomic Energy Act of 1946 created the Atomic Energy Commission (AEC) to encourage the use of nuclear power and regulate its safety, which made development of commercial nuclear 
power in the private sector possible. The US Government has actively promoted the development of commercial nuclear power and, while the US has more private sector participation in the production of civilian nuclear power than any other nation, the government is heavily involved through safety and environmental regulations, R\&D funding, and setting national energy goals (DOE 2008).

The Energy Reorganization Act of 1974 redistributed the functions performed by the AEC to two new agencies. The Nuclear Regulatory Commission (NRC) began operations in January 1975 as an independent authority to regulate private sector and non-military governmental nuclear power. NRC regulates the possession and use of nuclear materials as well as the siting, licensing, construction, and operation of nuclear facilities, including commercial nuclear waste management facilities. The Energy Research and Development Administration (ERDA) was established to ensure development of all energy sources, increase efficiency and reliability of energy resource use, and oversee military, production, and research activities. (DOE 2008)

The Department of Energy Organization Act (1977) brought a number of the Federal government's agencies and programs, including ERDA, into a single agency. The purpose was to achieve better coordination of policy by putting previously disparate agencies and programs together into a single Cabinet-level department. The Secretary of Energy reports to the President. The Department of Energy (DOE) was given responsibility for, among other matters, nuclear energy, the nuclear weapons programs, the government's 21 national laboratories, nuclear-related activities for environmental remediation of contaminated sites, and radioactive waste management activities for Government-owned and generated waste and materials. DOE has regulatory authority over its facilities and nuclear activities, and those operated or conducted on its behalf, except where NRC is specifically authorized by statute to regulate. (DOE 2008; WNA 2011z). Within the DOE, the Office of Environmental Management (EM) maintains waste management policies, assures the availability of these corporate resources, seeks efficiencies in operations, develops solutions to unique circumstances, and provides a complex-wide perspective, and addresses regulatory and policy issues. The Office of Health, Safety, and Security (HSS) establishes policies, standards and guidance on the safe and environmentally responsible conduct of the DOE mission, including policy and standards for nuclear safety and protection of the public and the environment, along with guidance to foster and facilitate DOE compliance with environmental laws and regulations (HSS 2011). In addition, the Environmental Protection Agency (EPA) has responsibility, among others things, to repair the damage already done to the environment and establish generally applicable environmental standards to protect the environment from hazardous materials and certain radioactive materials (DOE 2008). In general, commercial radioactive waste management is paid for through the Nuclear Waste Fund, into which utilities pay a $0.1 \mathrm{cent} / \mathrm{kWh}$ produced (WNA 2011x).

The radioactive waste classification scheme as used by NRC for commercial waste is different from the waste classification used by DOE for its radioactive waste. Table 2 and Table 3 provide commercial and DOE radioactive waste classifications, respectively. When the waste contains both radioactivity and hazardous contents it is called mixed waste. The transuranic (TRU) waste is not classified as a separate category for waste generated at non-DOE sites. In addition, commercial LLW is further classified as Class A, B, C, and Greater than Class C (GTCC) waste. 
Table 2. US Commercial Radioactive Waste Classification

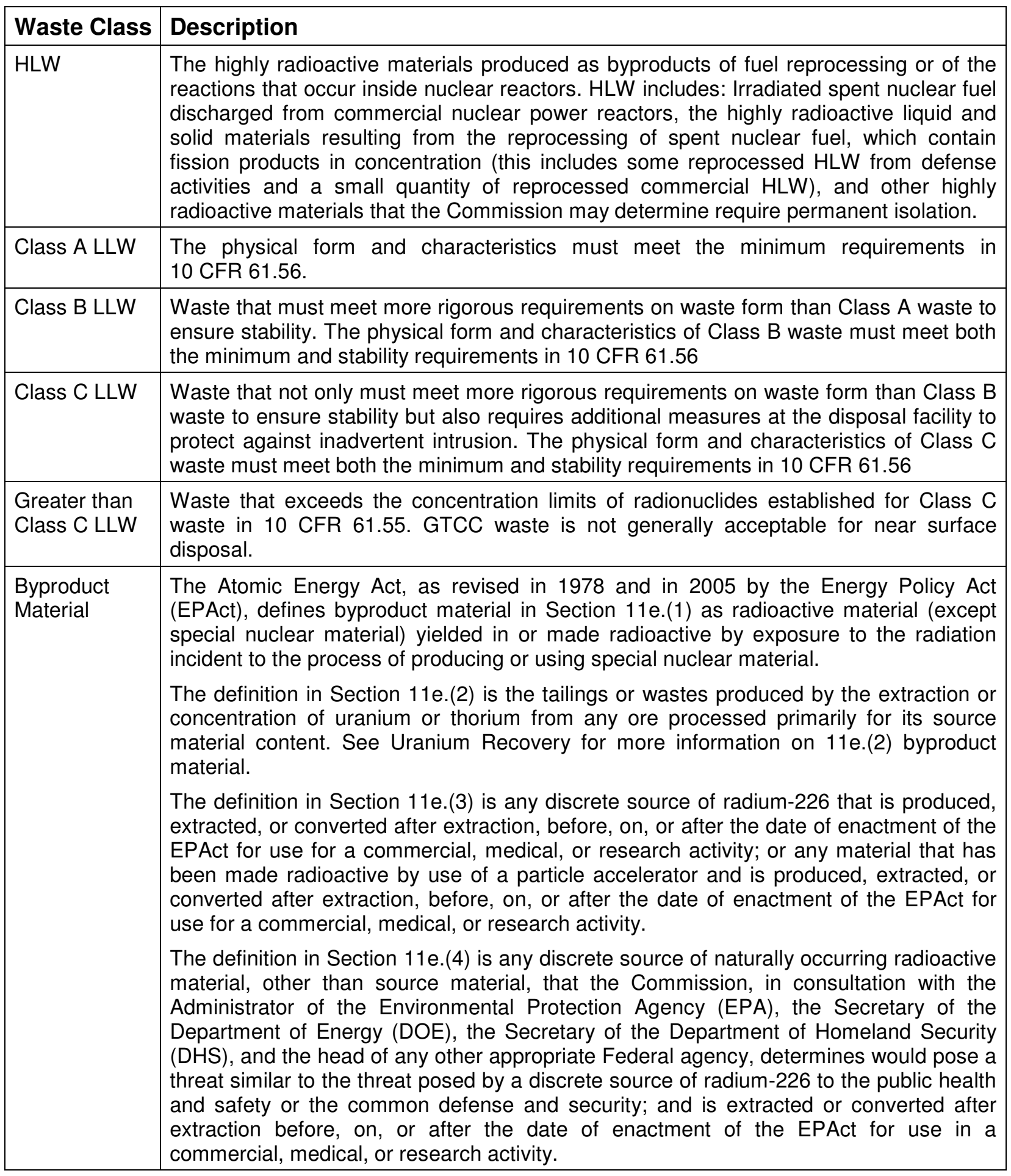

Source: Definitions from NRC 1982. 
Table 3. DOE Radioactive Waste Classification

\begin{tabular}{|l|l|}
\hline Waste Class & Description \\
\hline HLW & $\begin{array}{l}\text { High-level waste is the highly radioactive waste material resulting from the } \\
\text { reprocessing of spent nuclear fuel, including liquid waste produced directly in } \\
\text { reprocessing and any solid material derived from such liquid waste that contains } \\
\text { fission products in sufficient concentrations; and other highly radioactive material } \\
\text { that is determined, consistent with existing law, to require permanent isolation. }\end{array}$ \\
\hline TRU & $\begin{array}{l}\text { Radioactive waste containing more than } 100 \text { nanocuries (3700 becquerels) of alpha- } \\
\text { emitting transuranic isotopes per gram of waste, with half-lives greater than 20 } \\
\text { years, except for: (1) High-level radioactive waste; (2) Waste that the Secretary of } \\
\text { Energy has determined, with the concurrence of the Administrator of the } \\
\text { Environmental Protection Agency, does not need the degree of isolation required by } \\
\text { the 40 CFR Part 191 disposal regulations; or (3) Waste that the Nuclear Regulatory } \\
\text { Commission has approved for disposal on a case-by-case basis in accordance with } \\
10 \text { CFR Part 61. }\end{array}$ \\
\hline LLW & $\begin{array}{l}\text { Radioactive waste that is not high-level radioactive waste, spent nuclear fuel, } \\
\text { transuranic waste, byproduct material (as defined in section 11e.(2) of the Atomic } \\
\text { Energy Act of 1954, as amended), or naturally occurring radioactive material. }\end{array}$ \\
\hline Byproduct \\
Material & $\begin{array}{l}\text { (1) Any radioactive material (except special nuclear material) yielded in or made } \\
\text { radioactive by exposure to the radiation incident to the process of producing or } \\
\text { utilizing special nuclear material, and (2) the tailings or wastes produced by the } \\
\text { extraction or concentration of uranium or thorium from any ore processed primarily } \\
\text { for its source material content. [Source: Atomic Energy Act of 1954, as amended, } \\
\text { section 11(e)] }\end{array}$ \\
\hline
\end{tabular}

Source: Definitions from DOE 2007.

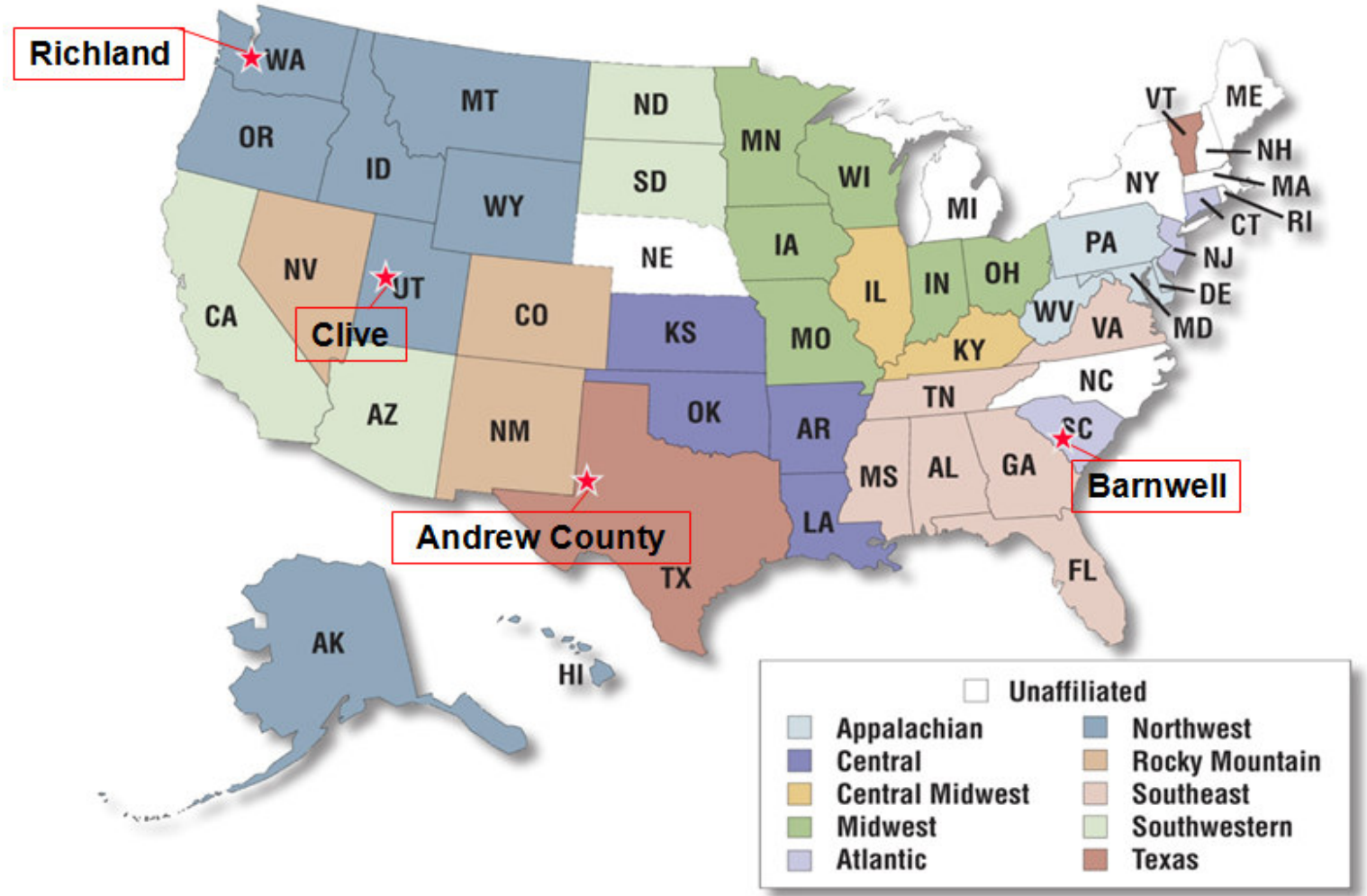

Figure 61. Commercial Disposal Facilities and LLW Interstate Compacts 


\section{Waste Management Practices and Facilities}

\section{Commercial Facilities}

Currently, there are three licensed operating commercial low-level waste disposal facilities in the US: Barnwell, SC; Clive, UT; and Richland, WA. The Barnwell and Clive locations are operated by EnergySolutions, whereas the Richland location is operated by US Ecology. A fourth facility in Andrews County, TX was licensed in 2009 and will be operated by Waste Control Specialists. Barnwell, Richland, and Andrews facilities accept low-level waste (LLW) Classes A, B, and C (with origin restrictions); whereas, Clive only accepts Class $A$, but from almost all regions of the United States. All four commercial LLW waste disposal facilities are located in and regulated by an Agreement State. The site locations for these facilities, along with the 10 United States regional compacts, are shown in Figure 61.

\section{Barnwell, SC}

The Barnwell Waste Management Facility, located approximately $8 \mathrm{~km}$ west of the city of Barnwell, in Barnwell County, SC, is operated by Chem-Nuclear Systems (CNS), LLC (a subsidiary of EnergySolutions). The entire site covers an area of approximately 278 acres (113 ha), with 235 acres for facility operations and 115 acres of these developed for disposal. The land is deeded to the State and leased to Chem-Nuclear Systems, LLC. The lease, administered by the SC Budget and Control Board, expires in 2075; however, closure activities began in 2008 and waste disposal operations are planned to end in 2038.

Initially licensed in 1969, Barnwell has been in operation since 1971 and historically accepted waste from all US generators. In 1979, with the closure of three of the six US commercial LLW disposal sites (in IL, KY, and NY), the Barnwell site was receiving more than three-quarters of the nation's waste. The increased rate of waste receipt led the State of South Carolina to establish annual disposal volume limits on the waste allowed to be received at the site. With the passage of the Low-Level Radioactive Waste Policy Act (LLRWPA) in 1980, Barnwell was designated the regional host facility for the Southeast Compact, consisting of eight states (AL, FL, GA, MA, NC, SC, TN, VA). But, it still received waste from out-of-compact states, contingent on their compact meeting specified milestones for new site development. In 1995, South Carolina withdrew from the Southeast Compact after continued delays in building a new regional disposal site in North Carolina (as set forth in the LLRWPA), and the Barnwell facility began accepting waste from generators in all states except North Carolina and the Northwest Compact (AK, OR, HI, UT, ID, WA, MT, WY). Effective July 2000, the Atlantic Compact Act enabled South Carolina to join the Atlantic Compact (CT, NJ, SC) and as of July 2008, the Barnwell site only accepts LLW waste from the three Atlantic Compact States (CT, NJ, SC).

Barnwell utilizes shallow land disposal. Sealed waste containers are placed in concrete vaults (stacked up to three high) located in engineered earthen trenches excavated up to about $9 \mathrm{~m}$ below grade. Sand is placed on the trench bottom to provide an even foundation for waste containers and ensure infiltrating water drains away. When a trench is full, sand and soil is backfilled around and over the vaults. An engineered cap consisting of multiple layers of sand, clay, high density polyethylene, and top soil covers the trench area. Shallow rooted grasses planted on top of the cap control erosion. The facility design exceeds federal regulatory requirements. Environmental sampling is performed not only as a monitoring function of the disposal facility, but also to establish a baseline body of data for comparison should circumstances dictate a need for concern. 
In addition to its Federal license from the NRC, the Barnwell site is licensed by the South Carolina Department of Health and Environmental Control (DHEC) for receipt, handling, and disposal of Class A, B, and C low level radioactive waste. Barnwell does not accept toxic chemical or liquid waste. As of 2008 , more than $790,000 \mathrm{~m}^{3}$ (or approximately 90 percent) of the total available disposal volume has been used, leaving only about $85,000 \mathrm{~m}^{3}$ for future waste disposal. The vast majority of this remaining space has been set aside for the decommissioning of the 12 nuclear power plants in the three state compact region, beginning around 2031 and lasting for about 20 years. Due to decay, approximately 3 million curies remain out of the more than 12 million curies total received and disposed to date (IAEA 2011a).

Clive, UT

The Clive disposal facility, operated by EnergySolutions (previously Envirocare of Utah, LLC), is currently the nation's largest LLW disposal facility. Located in Tooele County, it is situated in Utah's West Desert, approximately $120 \mathrm{~km}$ west of Salt Lake City, within a nearly 64,000 acre (26 ha) hazardous waste zone, which includes two hazardous waste incinerators, the Army's nerve gas storage site, and the Army's Dugway Proving Grounds (EIA 2005). The Clive facility was initially licensed by the State of Utah in 1988 for naturally-occurring radioactive material wastes (NORM). The facility has expanded in size and capabilities over the years and is currently permitted, licensed, and authorized to receive, treat, and dispose of Class A LLRW (beginning in 1991), naturally-occurring and accelerator produced radioactive material (NORM/NARM), PCB radioactive waste, asbestos-contaminated waste, mixed waste, and 11e.(2) Byproduct Material (but excludes biological wastes and sealed sources). In 2001, a separate license to accept Class B and C LLRW was issued pending legislature and gubernatorial approval; however, this license was subsequently appealed to the Utah Radiation Control Board (URCB) and the request was officially withdrawn in 2005.

The Clive site is located within the Northwest compact; however, it is not the compact's host LLW disposal facility. In 1992, the operators of the Clive site entered into an arrangement with the Northwest Interstate Compact that allowed them to accept certain types of low-level radioactive and mixed wastes from outside of the Compact. Although this arrangement has been subsequently modified and reviewed, Clive still accepts Class A LLW from Federal facilities and most regions of the United States (except those in the Northwest and Rocky Mountain Compacts, covered by the Richland facility, see below). In addition, EnergySolutions applied in 2008 to NRC to allow the importation of 20,000 tons of low level radioactive waste from Italy for disposal at its Clive facility. This application was opposed by both the State of Utah and the Northwest Compact; and, even though EnergySolutions has challenged the State's and Compact's authority to refuse foreign waste, the US Nuclear Regulatory Commission placed the application on hold until legal action is resolved.

The LLW operations are managed at two on-site facilities: bulk waste facility (BWF) and containerized waste facility (CWF). Clive uses above grade engineered disposal cells (or landfill embankments) to store LLW waste. The cell foundation, which consists of compacted in-situ clays or sands, is established below ground level approximately 4 to $6 \mathrm{~m}$ above the groundwater table. A half meter thick compacted low-permeability clay liner is put in prior to waste placement. Following final placement, the embankment side slopes and top are covered with a compacted $2 \mathrm{~m}$ thick low-permeability radon barrier, which is overlain by drainage, frost, and erosion protection layers. Currently, the Clive facility has three disposal embankments in use for LLW; each licensed embankment meets or exceeds the applicable regulatory requirements. In addition, the landfill cells are surrounded by a network of groundwater monitoring wells. The air, vegetation, and soils on and in close proximity to the site are monitored 
Clive receives all forms of LLW, including, but not limited to, soil, sludges, resins, large reactor components, dry active waste, and other radioactively contaminated debris. The facility is readily accessible by rail and truck and is designed to receive both bulk (e.g., intermodals, gondolas, etc.) and non-bulk (e.g., drums, boxes, etc.) containers. As of 2008, more than 2.8 million $\mathrm{m}^{3}$ (or 63 percent) of the total available disposal volume has been used, leaving approximately 1.7 million $\mathrm{m}^{3}$ for future waste disposal (IAEA 2011a). It should also be noted that EnergySolutions states on its company website that "Clive has enough capacity to dispose of all of the low-level radioactive waste from the eventual decommissioning of the 104 US nuclear reactors and still have abundant capacity, over 50 million cubic feet", which equates to more than 1.4 million $\mathrm{m}^{3}$ (WNN 2008).

Richland, WA

The Richland disposal facility, operated by US Ecology Incorporated (a subsidiary of American Ecology Corporation), is located in Benton County, Washington, approximately 23 miles northwest of the city of Richland. It is near the center of DOE's nearly 380,000 acre (153 ha) Hanford reservation on a 100 acre tract of land leased by the State of Washington from the federal government in 1964. The facility was opened in July 1965 and is expected to close in 2056, which is just 7 years before the 100 year state lease on the land expires.

Richland is the current host site for the Northwest Compact. The Northwest Compact was initially established in 1981 and included seven states: AK, OR, HI, UT, ID, WA, MT; an eighth state, Wyoming, joined the compact in 1992. Also in 1992, the Rocky Mountain Compact, comprised of Colorado, Nevada, and New Mexico, reached agreement with the Northwest Compact and the state of Washington to send up to 6,000 cubic feet of LLRW to the Richland disposal facility annually (plus a 3 percent per annum growth factor). In 1993, the Northwest Compact placed origin restrictions on the waste that the Richland disposal facility could accept and currently takes waste from only the eleven states of the Northwest and Rocky Mountain Compacts.

The Richland site practices conventional shallow-land burial of packaged waste, generally metal drums or metal boxes, which is usually put directly into the unlined trenches. The trenches are approximately $240 \mathrm{~m}$ long, 45 feet wide. and 14 feet deep. There are currently three open and operating trenches and 20 filled trenches. The filled trenches have been covered with at least five feet of site soils. In addition to the trenches, five underground storage tanks were installed for treatment and disposal of liquid low-level radioactive resin wastes.

Several types of waste have been disposed of at the commercial Richland LLW disposal site since it began operation in 1965. Waste types include LLW, naturally occurring and acceleratorproduced radioactive materials (NORM/NARM), non-radioactive hazardous and mixed waste. Since 1985, Richland is licensed by the State of Washington to receive only Class A, B, and C LLW, as well as (NORM/NARM). The Richland facility has a large amount unused capacity to accept LLRW. As of 2008, about $400,000 \mathrm{~m}^{3}$ (or only 23 percent) of the total available disposal volume has been used (approximately 95 percent of which is class $A$ ), leaving more than 1.3 million $\mathrm{m}^{3}$ for future waste disposal (IAEA 2011a; WA DOH 2005). 
Andrew County, TX

A new facility, to be owned and operated by Waste Control Specialists, LLC (WCS), is planned for northwestern Andrews County, Texas. The Andrews site covers approximately 14,400 acres (5,800 ha) of property, which is primarily in Texas with nominal acreage in New Mexico. The operating facilities area is more than 1,300 acres (nearly 530 ha) within the WCS site that includes proposed Federal Waste Facility (FWF) and Compact Waste Facility (CWF) landfills, byproduct material waste disposal facility, existing RCRA (Resource Conservation and Recovery Act) landfill, RCRA storage and processing units, and TX DSHS (Texas Department of State Health Services) licensed waste storage and processing activities. The total estimated disposal capacity is more than $790,000 \mathrm{~m}^{3}$ (TX CEQ 2009).

In 2003, Texas law-makers passed legislation that allowed private interests to apply for an NRC Part 61 LLW disposal site license. In response to the new law, in August 2004, WCS submitted a license application to the Texas Commission on Environmental Quality (TCEQ) for authorization to construct a near-surface LLW disposal facility. In September 2009, the Texas Commission on Environmental Quality issued a license for WCS to accept Classes A, B and C LLW from the Texas Compact (TX and VT), as well as the federal government. The Andrews WCS site is also permitted for GTCC LLW storage, PCB-contaminated waste treatment, storage and land disposal, AEA Section 11e.(2) waste storage, and NRC exempt and exempt-mixed waste land disposal, including selected NORM waste.

The Andrews WSC site is the only commercial LLW disposal facility under consideration in the United States at this time. It should also be noted that, in early 2010, the Texas Low-Level Radioactive Waste Disposal Compact Commission proposed the reasonable and responsible exportation and importation of LLW into and out of the Texas Compact Andrews facility (Texas Register 2010; TLLRWDCC 2010). In fact, without this importation, the Andrews WCS facility would not be economically viable, and jobs and other economic benefits to Andrews County and the State would be lost (Baltzer 2010). In January 2011, the Texas commission regulating radioactive material voted to let the site accept LLW shipped in from 36 other states (Schechter 2011).

Initial LLRW disposal cell construction for each of the proposed disposal facilities (FWF and CWF) will be completed prior to any waste placement, and the disposal cells will be progressively expanded, in a phased manner, as waste disposal capacity is utilized. The top 9 to $15 \mathrm{~m}$ of material at the site is alluvial material. Beneath this is a low-permeability clay formation known as the red beds, which extends to a depth of over $300 \mathrm{~m}$, and contains interbeds of sandstone at various depths. Waste disposal will be entirely within the red beds. After the disposal units are filled with waste, a low-permeability cover of red bed material will be constructed over the top of the cells. The remainder of the excavation will be closed, from the bottom up, with clay fill material, a shotcrete (or concrete that is applied by force) barrier, a compacted clay performance layer, a lateral sand drain layer, additional clay fill material, a rock layer for erosion and bio-intrusion protection, and a final vegetated soil layer.

\section{DOE Sites}

DOE has a national system for managing government radioactive waste. This includes six active LLW sites under management; however only the Nevada Test Site (NTS) and Savannah River Site (SRS) accept waste from other off-site DOE facilities. Oak Ridge, TN site only accepts waste from cleanup projects. The Hanford site and Idaho National Laboratory (INL) site 
also accept LLW generated from cleanup projects. The site locations for these facilities, along with other smaller DOE low-level and mixed low-level disposal facilities, are shown in Figure 62.

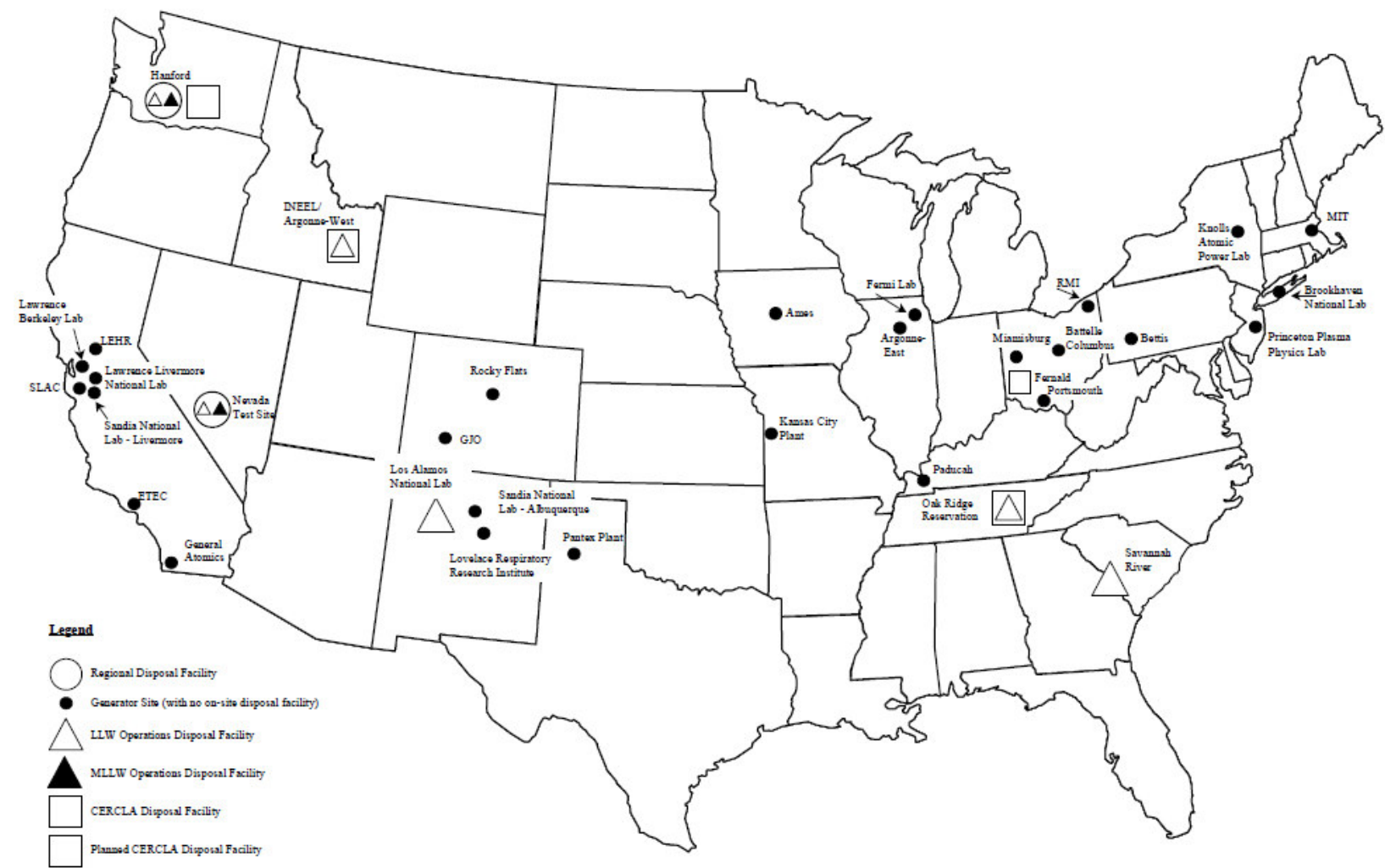

Figure 62. DOE Low-Level and Mixed Low-Level Disposal Facilities

Hanford Site, WA

The Hanford Site occupies a geographically diverse land area of nearly 380,000 acres (more than 150,000 ha) in the southeastern portion of the State of Washington. The site is northwest of the City of Richland, Washington, on the Columbia Plateau. It is bounded on the north by the Saddle Mountains, on the east by the Columbia River, and on the south and west by the Yakima River and the Rattlesnake Hills, respectively. A large area of pristine shrub-steppe habitat, the Hanford Site is bisected by the Columbia River and nearly 9,000 acre of the river's surface water flow is within the geographic boundary of the Site. In contrast, the Hanford Site is also included on the CERCLA National Priorities List (NPL) of contaminated sites.

Established in 1943, the Hanford Site is owned by the Federal government and has been managed by the Manhattan Project, AEC, ERDA, and currently US DOE, Richland Operations Office (RL). From the 1940s through 1980s, the primary mission at Hanford was to produce nuclear materials in support of United States defense, research, and biomedical programs. Operations associated with those programs used facilities for fabrication of nuclear reactor fuel, reactors for nuclear materials production, chemical separation plants, nuclear material processing facilities, research laboratories, and waste management facilities. Plutonium production at Hanford has since ceased, and DOE activities at the site currently include research, environmental restoration, and waste management. 
Hanford Site waste accounts for nearly two-thirds by volume of the nuclear waste in the DOE complex. The site contains vast amounts of both radioactive and hazardous wastes. Currently, about 10 percent of Hanford Site's waste is radioactive, and 75 percent of the site's waste is contaminated with both radioactive and hazardous components. The most abundant contaminants are tritium, carbon tetrachloride, chromium, nitrates, cobalt, strontium, cesium, technetium, iodine, plutonium, and uranium. The disposal facilities at the Hanford Site are operated by the Waste Management (200 Area Burial Grounds) and the Environmental Restoration program. As of 2008, more than 3.9 million $\mathrm{m}^{3}$ of LLW has been disposed of, which is only about 17 percent of the total estimated available disposal volume, leaving nearly 20 million $\mathrm{m}^{3}$ for future waste disposal (IAEA 2011a).

The Hanford Site 200 Area Burial Grounds is classified as a shallow landfill disposal facility, which covers an area of about 48,000 acre (nearly $20 \mathrm{ha}$ ). The 200 Area facility is divided geographically into three regions: East, West, and North. These areas are further divided into smaller burial grounds. The capacity at this facility is based on the standard trench design, typically either wide-bottomed or V-shaped, currently used at the facility. The design involves use of unlined trenches having sloped (about 45 degrees) sides. The dimensions of the standard trench design are $6 \mathrm{~m}$ deep, $12 \mathrm{~m}$ wide at the base, $30 \mathrm{~m}$ wide at the surface, but vary in length up to approximately $490 \mathrm{~m}$. The design assumes that $11 \mathrm{~m}^{3}$ of waste in each linear foot of trench length. Based on the standard trench design, the 200 Area Burial Grounds have a combined disposal capacity of nearly 2 million $\mathrm{m}^{3}$ of LLW.

The Environmental Restoration Disposal Facility (ERDF) is located on the Central Plateau between the 200 East and West Area. ERDF is a massive landfill that is regulated by the United States Environmental Protection Agency (CERCLA disposal facility), with a maximum waste volume of more than 21 million $\mathrm{ft}^{3}$ (DOE 2000). Only Hanford Site waste resulting from remediation of the 100, 200, and 300 Areas will be disposed in the ERDF. Its Record of Decision (ROD) was signed in January 1995 and construction of the first two cells concluded in 1996. The first load of contaminated material was disposed at the ERDF on July 1, 1996. The ERDF accepts materials that come from building demolition projects (e.g., construction debris, glass, paper, metal pipe/shapes, and plastics) and solid waste burial ground excavations at Hanford. Contaminated soil makes up the largest portion of the volume estimated to be disposed at this facility. The facility currently consists of 8 disposal areas known as cells, built two at a time, which measure about $430 \mathrm{~m}$ by $220 \mathrm{~m}$ at the top of the trench and $300 \mathrm{~m}$ by $150 \mathrm{~m}$ at the bottom of the trench. The ninth cell, a so-called "super cell", is currently under construction. When completed it will be the largest one at about double the capacity of an existing cell at ERDF (DOE 2010). As future remediation and disposal decisions are made, DOE plans to construct additional cells as needed.

The Hanford site is also a RCRA interim status facility for disposal of MLLW. Disposal of MLLW began at this facility in 1999. The facility, which is located in the 200 West Area, consists of two trenches (31 and 34 ) with an estimated disposal capacity of more than $42,000 \mathrm{~m}^{3}$.

In addition, US Ecology, Inc. operates the commercial Richland LLW disposal facility on 100 acres (40 ha) of the Hanford Site near the 200 East Area leased by the State of Washington from DOE. This facility is licensed by the US Nuclear Regulatory Commission (NRC) and the State of Washington, not DOE. The US Ecology Richland facility is one of three commercial LLW disposal facilities in the United States (for further information, see above). 
Idaho National Laboratory (INL), ID

The Idaho National Laboratory (INL) site occupies approximately 570,000 acres (230 ha) and is located about $50 \mathrm{~km}$ west of Idaho Falls in southeast Idaho. Previously known as Idaho National Engineering and Environmental Laboratory (INEEL), the facility name was shortened in 2005 when Battelle Energy Alliance took over operation of the lab and merged with Argonne National Laboratory-West. The site sits on the Eastern Snake River Plain and is bordered by the Biterroot, Lemhi, and Lost River mountain ranges. The INL is within the Medicine Lodge and Big Butte Resource Areas, which are administered by the Bureau of Land Management. Only, about two percent of the total INL area $(11,400$ acres) is used by the DOE for facilities and operations.

The site was established in 1949 as the National Reactor Testing Station, where the Atomic Energy Commission (AEC) built, tested, and operated various types of nuclear reactors. As of April 1991, 52 reactors had been built at the site, with 13 still operating or operable. In addition to nuclear reactor research, other INL facilities support reactor operations; processing and storage of high-level waste, low-level mixed waste (LLMW), and LLW; disposal of low-level waste; and also storage of transuranic (TRU) waste generated by national defense program activities. Today, INL is one of DOE's multiprogram national laboratories with numerous research and development activities, including reactor performance, materials testing, environmental monitoring, natural resources research and planning, and waste processing.

One LLW disposal facility, the Radioactive Waste Management Complex (RWMC), is presently operating at INL. The 144-acre complex is located in the southwest portion of the site and was established in 1952 for the disposal of defense wastes (mostly transuranic), solid LLW, and MLLW generated at INL. Today, the facility provides waste management, interim storage of transuranic waste, and disposal of INL-generated LLW, but provides no means for disposing of MLLW (since April 1984). As of 2008, more than $300,000 \mathrm{~m}^{3}$ of LLW has been disposed of, which is approximately 60 percent of the total estimated available disposal volume, leaving approximately $184,000 \mathrm{~m}^{3}$ for future waste disposal (IAEA 2011A; IOO 2006).

The RWMC accepts LLW for disposal from INL on-site sources. It consists of two main disposal and storage areas: Transuranic Storage Area, Pad A, for storage and examination of transuranic waste, and Subsurface Disposal Area (SDA) for disposal of LLW. The SDA is a 97-acre area in the western part of the complex surrounded by a flood control dike and drainage channel. Since 1952, waste has been buried at the SDA in pits, trenches, soil vault rows, and concrete vaults. The major burial areas presently open are the pits, which are $30 \mathrm{~m}$ by about 3 to $6 \mathrm{~m}$ and vary from 60 to $360 \mathrm{~m}$ long. Pits are generally excavated to bedrock depth (about $9 \mathrm{~m}$ ), and then backfilled with $0.6 \mathrm{~m}$ of soil over rock. After the waste is placed on the soil by high-density stacking, the pits are backfilled with at least $1 \mathrm{~m}$ of soil. Remote-handled waste in concrete vaults is also disposed in the pits area. The RWMC total disposal capacity is estimated to be about $96,000 \mathrm{~m}^{3}$ and, as of 2006 , the disposal volume was about $31,000 \mathrm{~m}^{3}$ (IAEA 2011a).

INL was listed on the CERCLA NPL of contaminated sites in 1989, so there also exists an CERCLA disposal facility (ICDF) within the site boundaries, The ICDF's primary function is to provide a disposal site in one central location for waste from various cleanup sites at the INL. The ICDF landfill is an on-site, engineered facility for the disposal of hazardous, low-level waste (LLW), mixed low-level waste (MLLW), and polychlorinated biphenyl (PCB) contaminated soil and debris waste. The modular design disposal cells, which include a buffer zone, cover 
approximately 40 acres, have an estimated total disposal capacity of nearly $490,000 \mathrm{~m}^{3}$ and, as of 2006, the disposal volume was about 240,000 $\mathrm{m}^{3}$ (IAEA 2011A; IOO 2006).

Los Alamos National Laboratory (LANL), NM

Los Alamos National Laboratory (LANL) is located on the Pajarito Plateau in north-central New Mexico, within Los Alamos and Santa Fe Counties, approximately $100 \mathrm{~km}$ north-northeast of Albuquerque and $40 \mathrm{~km}$ northwest of Santa Fe. LANL occupies an area of approximately 27,500 acres (11,000 ha), bounded on the southeast by the Rio Grande. The area is dominated by the Jemez Mountains to the west and the Sangre de Cristo Mountains to the east. These two ranges flank the Rio Grande Valley, which roughly bisects the state from north to south. Developed land accounts for approximately 5 percent of the LANL area, therefore most of the site is undeveloped grassland, shrub land, woodland, and forest that serve to provide a buffer for security and safety and space for future expansion.

Established during World War II, in support of the Manhattan project and for the sole purpose of designing and building an atomic bomb, the laboratory was officially known as Project $Y$. In the years since the 1940s, Los Alamos was responsible for the development of the hydrogen bomb and has served as one of the primary classified US national laboratories designing the country's nuclear arsenal. At the end of the Cold War, LANL went through a process of intense scientific diversification in their research programs to adapt to the changing political conditions. Today, LANL is managed and operated by Los Alamos National Security (LANS) and conducts multidisciplinary research for fields such as national security, weapons development, outer space, renewable energy, medicine, nanotechnology, and supercomputing.

LANL has one operating LLW disposal facility, Area G within Technical Area-54 (TA-54). Beginning in 1957, TA-54 Area $G$ was used to dispose of waste generated from operations involving radioactive materials and waste, which would currently be classified as mixed waste. In 1970, the AEC directed its facilities to begin storing TRU waste, so that it could eventually be retrieved. So, LANL began segregating LLW from TRU waste and dedicating specific areas within Area $G$ for management of these wastes. Since 1986, TRU waste has been segregated for storage at TA-54 Area G. Today, LANL TA-54 Area G accepts on-site LLW for disposal, although in special cases off-site waste has been accepted from Defense Programs sites.

Area G currently occupies 64 acres (26 ha) and consists of landfill cells (pits and trenches) and land disposal shafts. Typically, pits are rectangular, about $20 \mathrm{~m}$ wide, $150 \mathrm{~m}$ long, and $20 \mathrm{~m}$ deep; whereas, shafts are typically cylindrical, about $20 \mathrm{~m}$ deep and range in diameter from around 0.5 to $1 \mathrm{~m}$. As of 2008 , nearly $250,000 \mathrm{~m}^{3}$ of LLW has been disposed of, which is only about 15 percent of the total estimated available disposal volume, leaving more than 1.3 million $\mathrm{m}^{3}$ for future waste disposal (IAEA 2011a). An additional 24 acres (nearly $10 \mathrm{ha}$ ), immediately adjacent to Area $\mathrm{G}$, is dedicated for future expansion of the LLW disposal area.

Nevada National Security Site (NNSS), NV

The NNSS formerly known as Nevada Test Site (NTS) is located in Nye County, NV and encompasses approximately 867,000 acres $(350,000 \mathrm{ha})$ in southern Nevada. It is approximately $105 \mathrm{~km}$ northwest of Las Vegas. To the north, east, and west, the mountainous and undeveloped Federal-owned lands provide a buffer zone, varying from 24 to $105-\mathrm{km}$ wide, between the test areas and public lands. The Bureau of Land Management manages the land that borders on the southern and southwestern face of the site. Approximately 25 percent of NTS is undeveloped or provides buffer zones for ongoing programs and projects. Facility 
expansions are possible within all areas and encroachment from land development is not a concern.

TheNNSS has historically been the continental location of the US nuclear weapons testing program. However, since the moratorium on testing began in October 1992, this mission has changed to maintain a readiness to conduct tests, if so directed, in the future. Currently, much work on the NNSS has been and continues to be related to national defense and other nationalsecurity-related research, development, and testing programs. However, there is growing emphasis on environmental restoration and waste management programs, which have been part of NNSS operations since the beginning of the nation's nuclear testing program.

In 1961, the US government began utilizing the NNSS for disposing LLW. Initially, the waste was generated by the weapons testing program; however, later it was also generated through DOE environmental restoration activities. Since 1976, NNSS disposal activities have expanded to include receipt of LLW generated at other DOE and US Department of Defense (DoD) facilities throughout the US. The NNSS RWMS currently receives LLW from 15 generators including: Aberdeen Proving Grounds; AlliedSignal; Bechtel Nevada; Boeing North AmericanRocketdyne; Fernald Environmental Management Project; General Atomics; International Technology Corporation, Las Vegas; Lovelace Respiratory Research Institute; Mound Plant; Pantex Plant; RMI Environmental Services; Rocky Flats Plant; Sandia National Laboratories, California; and Sandia National Laboratories, New Mexico. As of 2008, more than 1 million $\mathrm{m}^{3}$ of LLW has been safely disposed at the Area $3 \& 5$ sites, which is only about 28 percent of the total available disposal volume, leaving approximately 2.7 million $\mathrm{m}^{3}$ for future waste disposal.

The NNSS also operates its disposal facilities within two Radioactive Waste Management Sites (RWMS): Area 5 and Area 3. Area 5, accepts LLW materials that were generated in the Nation's Defense Programs (DP) activities. This more than 730-acre (nearly 300 ha) complex, of which 160 acres (65 ha) in current use for the storage and disposal facility, is approximately $240 \mathrm{~m}$ above ground water levels. It consists of shallow, excavated LLW disposal trenches, which range in depth from about 4 to $15 \mathrm{~m}$. As the cells are filled to capacity, the LLW is covered with a $2.5 \mathrm{~m}$ thick layer of native soil. At closure, a cap is put in place. Also located at the Area 5 site is aboveground storage for TRU waste awaiting transfer to the Waste Isolation Pilot Plant (WIPP) and Greater Confinement Disposal Units, which consist of $3 \mathrm{~m}$ in diameter partially cased shafts that are nearly $37 \mathrm{~m}$ deep and were previously used for disposing of waste not suited for shallow land burial because of high exposure and potential for migration into biopathways. Nonradioactive hazardous wastes are also accumulated at the Area 5 site awaiting shipment to offsite treatment and disposal facilities. The Area 3 site covers about 120 acres (49 ha), but has limited available capacity remaining. Historically, larger (e.g., concrete monoliths, cargo containers) or bulk form LLW (e.g., debris collected from atmospheric nuclear test locations) was disposed of in surface subsidence craters (that were formed in the early 1960s by underground nuclear tests), which are approximately 490 feet above ground water levels. The waste packages were layered in cells separated by up to $1 \mathrm{~m}$ layer of fill soil. Once the two currently inactive disposal cells are filled to capacity, it is anticipated that Area 3 will undergo closure the processes. Additionally, there are facilities for the storage, characterization, and certification of Transuranic Waste.

\section{Oak Ridge Site (ORR), TN}

The Oak Ridge Reservation (ORR) consists of approximately 35,000 acres $(14,000$ ha) of Federal-owned lands located in East Tennessee, approximately $40 \mathrm{~km}$ east of Knoxville. The site spans Anderson and Roane Counties and is within the incorporated city limits of Oak Ridge, 
TN, with the residential section of Oak Ridge forming the northern boundary of the reservation. The Tennessee Valley Authority's Melton Hill and Watts Bar reservoirs on the Clinch and Tennessee Rivers form the eastern, southern, and western boundaries.

Dating back to World War II, the Atomic Energy Commission established ORR in 1942 to play a major role in the production of enriched uranium for the Manhattan Project, maintenance of materials and components for nuclear weapons, and preservation of a technological lead over the Soviet Union. Today, Oak Ridge remains as a legacy to the Cold War, but has expanded beyond that first mission. Currently owned by DOE, it is home to a world leading research and manufacturing park, with major federal programs in the areas of science, environmental management, energy efficiency, nuclear fuel supply, reindustrialization, and national security. ORR is also currently listed on the CERCLA NPL of contaminated sites.

The ORR includes three large industrial production facilities. The Oak Ridge National Laboratory (ORNL), formerly known as the $\mathrm{X}-10$ Site, is a research facility that includes nuclear reactors and ongoing energy, chemical, and biological programs. The Y-12 National Security Complex, which is a facility that formerly production enriched uranium-235 by an electromagnetic process, and currently disassembles nuclear weapon components, processes nuclear materials, and performs other functions, related to energy and national defense programs. Finally, the East Tennessee Technology Park (ETTP), formerly the K-25 Site, is a past production facility that enriched uranium-235 by gaseous diffusion. In the past decade, the missions of ORNL and Y-12 have continued to evolve, while ETTP will be cleaned up for eventual use as a private-sector industrial park.

LLW disposal activities have been primarily occurred at four ORR facilities: Interim Waste Management Facility (IWMF); CERCLA Environmental Management Waste Management Facility (EMWMF); Hydrofract; and Solid Waste Storage Areas. The IWMF, located within the 68-acre southwest region of ORR designated as Solid Waste Storage Area (SWSA) 6, was constructed in 1991 for LLW disposal from on-site non-environmental-restoration activities (disposal capacity of about $5,600 \mathrm{~m}^{3}$ ). Operations ceased in 2001, with the facility at less than 70 percent capacity, and LLW generated from non-environmental-restoration activities at the ORR are directed to other facilities for disposal. The CERCLA disposal facility (EMWMF) was developed to manage environmental restoration waste generated at ORR as a result of other CERCLA RODs, with a maximum waste volume of approximately 1.7 million $\mathrm{m}^{3}$. Since its operation began in 2002, nearly $650,000 \mathrm{~m}^{3}$ of LLW has been disposed of within the EMWMF facility. In addition, past disposal practices, including Hydrofract (deep well injection) and Solid Waste Storage Areas (Old Burial Grounds), account for more than $450,000 \mathrm{~m}^{3}$ of disposed LLW material. As of 2008 , the total volume of disposed material at these ORR facilities adds up to more than 1.1 million $\mathrm{m}^{3}$.

\section{Savannah River Site (SRS), SC}

The Savannah River Site (SRS) is located in south-central South Carolina about 12 miles south of Aiken. The site occupies an area of approximately 192,000 acres (78,000 ha), ranging from about 24 to $130 \mathrm{~m}$ above mean sea level. The SRS's major geophysical feature is the Savannah River, which forms the site's southwestern boundary.

The DOE's primary mission at the SRS, from its construction in the 1950s until the recent end of the Cold War, was the production and processing of nuclear materials to support defense programs. The end of the Cold War has led the United States to a reduction in the size of it's the US nuclear arsenal. Many of the more than 120 facilities across the country, including SRS, 
that DOE used to manufacture, assemble, and maintain the former arsenal were either decommissioned or converted to new uses through decontamination processes. In addition, the wastes generated during the Cold War must be cleaned up in a safe and cost-effective manner. DOE must also manage wastes that might be generated in the future by ongoing operations, including new defense facilities that might be located at SRS. Accordingly, the SRS's current missions include site remediation and safe processing of nuclear materials.

The Savannah River Site accepts waste from different DOE sites across the US. Disposal of solid LLW at SRS traditionally has been accomplished using engineered trenches in accordance with the guidelines and technology existing at the time of disposal. The E-Area occupies 200 acres ( $81 \mathrm{ha}$ ), approximately $10 \mathrm{~km}$ from the nearest plant boundary. The original disposal site area (about 80 acres) began to receive waste in 1953 and was filled in 1972, when operations were shifted to a contiguous 120 acre site. In 1986, part of the site was closed and designated as a mixed waste facility, because it contained hazardous material. Since these older facilities are now filled, currently compacted and packaged LLW is deposited for burial in the 100-acre E-Area Low Activity Waste (LAW) Vaults, Intermediate Level Waste (ILW) Vaults, and Trenches. Waste material to be disposed in trenches is generally material with the potential to be contaminated with radionuclides (i.e., environmental restoration soil or building decommissioning rubble from regulated areas), but is neither tritiated waste nor designated as LAW or ILW. As of 2008, nearly 1 million $\mathrm{m}^{3}$ of LLW has been disposed at the STS, which is nearly 60 percent of the total available disposal volume, leaving nearly $680,000 \mathrm{~m}^{3}$ for future waste disposal. Monitoring wells are located near each disposed waste area to verify performance and to monitor groundwater in the vicinity of the vaults.

\section{Current and Future Initiatives}

Currently for public and private institutions and corporations, in addition to all federal (except $\mathrm{DOE}$ ) and state agencies located in 7 regional compacts (illustrated in Figure 61) there is no disposal option available for Class B and Class C LLW waste. The Barnwell and Richland sites accept Class B and Class C waste from Atlantic and Northwest and Rocky Mountain compact, respectively. The new proposed facility at Andrew County, TX is currently licensed to accept waste only from Texas Compact as well as from DOE facilities. With the approved changes to the license, for reasonable and responsible exportation and importation of LLW into and out of Texas Compact, it is likely some of the Class B and Class C waste from other Compacts may be disposed in Andrew site.

Nuclear Power Plants that also do not have a disposal outlet for Class B and C waste and are likely to continue to accumulate Class B and Class $C$ waste at an annual rate of up to 5.5 to $7 \mathrm{~m}^{3}$ per unit (NRC 2009b). Currently there are 90 operating reactors that do not have access to disposal option for their Class B and Class C LLW. The lack of disposal access has become an issue in the licensing of new reactors. NRC reaffirmed and summarized its earlier guidance related to LLW storage at reactor sites in 2008 (NRC 2008b).

The total annual volume of Class B and Class $C$ for different material licensees could be as much as $28 \mathrm{~m}^{3}$ (NRC 2009a). To deal with this situation, NRC issued a Regulatory Issue Summary for materials and fuel cycle licensees on extended interim storage of LLW (NRC 2008a). NRC in its 2009 Policy Issue Information has concluded that although fuel cycle facilities and material licensees can effectively store Class B and Class $C$ waste for extended period of time but licensees that produce liquid Class B or Class $C$ waste, licensees undergoing decommissioning, or licensees that are relocating their facilities may have difficulty managing their waste (NRC 2009a). Council on Radionuclides and Radiopharmaceuticals (CORAR) in 
their testimony to Texas Low-Level Radioactive Waste Disposal Compact Commission mentioned that many biomedical research products have been deleted due to radioactive waste issues (CORAR 2010).

Considering the current situation there is a need for a long-term solution for Class $\mathrm{B}$ and Class C LLW disposal. To mitigate the impact of closing of the Barnwell LLW disposal facility, NRC is working on guidance or rulemaking on the blending of low-level waste. Industry has proposed approaches in which Class B and Class C LLW waste is mixed with Class A waste to form a Class $A$ mixture that can be disposed at a Class $A$ disposal facility such as an existing licensed facility at Utah. NRC regulations guidance currently discourages down blending but do not prohibit it and acknowledge that it may be appropriate in some cases. To address this issue NRC staff has prepared a vote paper to address the policy issues related to blending of lowlevel radioactive waste (NRC 2010).

\section{CONCLUSIONS}

\section{Nuclear Capabilities}

Currently, there are 31 countries across the globe operating a total of 433 nuclear power plants, with a total capacity of more than $365 \mathrm{GW}(\mathrm{e})$. There are also 65 new reactors under construction mainly at NPPs in Eastern Asia and Eastern Europe. Table 4 provides a summary of the nuclear facilities for the countries covered in this report, which spans 6 continents and approximately 90 percent of the combined number of worldwide reactors in operation, units under construction,

and

total

power

generated. 
Table 5 summarizes the percentages of domestic and worldwide nuclear electricity generation for these same countries.

The U.S. has the largest number of commercial reactors with 104 in operation, but they have only one reactor currently under construction. The U.S. derives almost 20 percent of its domestic electricity from nuclear power, an amount that accounts for nearly 30 percent of worldwide nuclear generated electricity. The U.S. also has the largest number of units in permanent shutdown. France with 58 operating nuclear reactors, has about half number of the U.S., and also has one unit under construction. These nuclear facilities account for nearly three-quarters of the domestically generated electricity, and nearly 20 percent of that produced worldwide. France has the fourth largest number of nuclear power reactors in permanent shutdown. With respect to operating rectors, Japan, with 50 units (plus 2 under construction), follows closely after France; and, as a result of the 2011 Fukushima-Daiichi disaster, Japan now ranks fifth in the total number of reactors in permanent shutdown. Japanese NPPs supply nearly 30 percent of its nation's electricity and about 12 percent of that worldwide. Rounding out the top four countries in terms of number and nuclear power generation is Russia, which has 32 operating reactor units (11 under construction) providing about 10 percent of its total electricity capacity, but only about $6 \%$ of nuclear generated electricity worldwide.

Table 4. Summary of the Nuclear Facilities ${ }^{a}$

\begin{tabular}{|l|c|c|c|c|c|c|c|c|}
\hline \multirow{2}{*}{ Country } & \multicolumn{2}{|c|}{ In Operation } & \multicolumn{2}{c|}{$\begin{array}{c}\text { Under } \\
\text { Construction }\end{array}$} & \multicolumn{2}{c|}{$\begin{array}{c}\text { Long-term } \\
\text { Shutdown }\end{array}$} & \multicolumn{2}{c|}{$\begin{array}{c}\text { Permanent } \\
\text { Shutdown }\end{array}$} \\
\cline { 2 - 10 } & No. & Total GW(e) & No. & Total GW(e) & No. & Total GW(e) & No. & Total GW(e) \\
\hline Argentina & 2 & 0.9 & 1 & 0.692 & & & & \\
\hline Armenia & 1 & 0.4 & & & & & 1 & 0.4 \\
\hline Australia & & & & & & & & \\
\hline Belgium & 7 & 6 & & & & & & 0.01 \\
\hline Brazil & 2 & 1.9 & 1 & 1.2 & & & & \\
\hline Bulgaria & 2 & 1.9 & 2 & 1.9 & & & 4 & 1.6 \\
\hline Canada & 18 & 12.6 & & & 4 & 2.5 & 3 & 0.5 \\
\hline China & 15 & 11.1 & 27 & 27.2 & & & & \\
\hline France & 58 & 63.1 & 1 & 1.6 & & & 12 & 3.8 \\
\hline Germany & 9 & 12.1 & & & & & 27 & 14.3 \\
\hline India & 20 & 4.4 & 6 & 4.2 & & & & \\
\hline Japan & 50 & 44.2 & 2 & 2.6 & 1 & 0.25 & 9 & 4.3 \\
\hline Korea & 21 & 18.7 & 5 & 5.6 & & & & \\
\hline Russia & 32 & 22.7 & 11 & 9.2 & & & 5 & 0.8 \\
\hline Sweden & 10 & 9.3 & & & & & 3 & 1.2 \\
\hline Ukraine & 15 & 13.1 & 2 & 1.9 & & & 4 & 3.5 \\
\hline United Kingdom & 18 & 9.9 & & & & & 27 & 3.5 \\
\hline United States & 104 & 101.2 & 1 & 1.2 & & & 28 & 9.8 \\
\hline
\end{tabular}

a The values in the table are as of September 2011 and derived from IAEA 2011b.

The next four countries in terms of operating reactor numbers are Korea, India, Canada, and UK, and Germany. These countries all have around 20 operating units, and each accounts for five percent or less of the internationally generated electricity from NPPs. Domestically, Korea 
gains about 25 percent of its electricity needs from nuclear power; whereas just less than three percent of India's electricity is produced from its nuclear power sector. Korea has five reactor units currently under construction, and India has six. For the Canada and UK, nuclear power accounts for 14 and 18 percent, respectively, of the total electricity produced domestically within each country. Neither of these two countries have any reactors under construction. However, the UK ranks second (tied with Germany, after the US) in terms of nuclear power reactors in permanent shutdown.

The Ukraine has the ninth largest number of operational nuclear reactors worldwide with 15 units; it has two additional ones under construction. These reactors produce nearly 50 percent of the nation's electricity, and account for about 14 percent of that produced worldwide. China has 15 operating reactors that provide for only about one percent of the country's electricity needs and account for less than three percent of the internationally generated nuclear electricity. However, there are 27 nuclear power reactors under construction in China. Sweden ranks eleventh in terms of operating nuclear reactors, with 10 units generating more than 40 percent of the nation's domestic electricity. As of March 2011, Germany follows closely with only nine operating reactors units. Belgium has seven operating reactors that meet more than 50 percent of its domestic electricity needs. With no new reactors currently under construction, Sweden, Germany, and Belgium each contribute only about two to three percent to the global nuclear generated electricity market. 
Table 5. Summary of Nuclear Electricity Generation

\begin{tabular}{|l|c|c|}
\hline \multirow{2}{*}{ Country } & \multicolumn{2}{|c|}{$\begin{array}{c}\text { Estimated Portion of Nuclear } \\
\text { Generated Electricity }\end{array}$} \\
\cline { 2 - 3 } & Domestic (\%) & International (\%) $^{\mathbf{a}}$ \\
\hline Argentina & 10 & 0.2 \\
\hline Armenia & 39 & 0.1 \\
\hline Australia & & 2 \\
\hline Belgium & 54 & 1 \\
\hline Brazil & 3 & 1 \\
\hline Bulgaria & 34 & 3 \\
\hline Canada & 14 & 3 \\
\hline China & 1 & 18 \\
\hline France & 74 & 5 \\
\hline Germany & 28 & 1 \\
\hline India & 3 & 12 \\
\hline Japan & 30 & 5 \\
\hline Korea & 25 & 6 \\
\hline Russia & 10 & 2 \\
\hline Sweden & 42 & 4 \\
\hline Ukraine & 48 & 3 \\
\hline United Kingdom & 18 & 27 \\
\hline United States & 20 & \\
\hline
\end{tabular}

a These estimations are based on available reported data values from: 2010 for China, France, and Germany; 2009 for Japan, Ukraine, and UK; 2008 for Argentina, Armenia, Belgium, Brazil, Korea, and Sweden; and 2007 for Bulgaria, India, and Russia

The remaining five countries covered in this report, Argentina, Brazil, Bulgaria, Armenia, Australia, each have two or less operating nuclear power reactors, which combined account for just over one percent of the nuclear generated electricity worldwide. Specifically, Argentina and Brazil each have two operating reactors, and one additional unit under construction. These reactors produce ten and three percent, respectively, of the country's electricity. Bulgaria gains about 35 percent of its electricity needs from its two nuclear power reactors and has two additional units under construction. Armenia generates nearly 40 percent of its domestic electricity from its one operating nuclear power reactor. Finally, Australia does not have a commercial nuclear power program, although it has some of the world's largest uranium deposits and actively mines and exports uranium for nuclear fuel.

\section{Waste Management Practice, Facilities, and Initiatives}

The existing LILW waste facilities, their waste management practices, and corresponding national initiatives for the countries covered in this report are summarized in Table 6. 


\section{Disposal Practices}

Numerous types of LILW disposal practices have been used historically and currently around the globe. The most commonly utilized forms involve near surface shallow land burial, placement in concrete surface vaults, shallow and deep underground geologic disposal, interim temporary storage options, and historic sea-based dumping.

Near-surface disposal techniques primarily involve shallow land burial of waste in natural and engineered earthen trenches (or pits) and engineered concrete cells. Some historical shallow land burial was performed without the use of any liners; however, the majority of disposal practice around the globe utilized linings that range from clay to stone to multi-layer engineered barriers. Countries that have or currently use near-surface disposal techniques for either LLW and/or VLLW include Argentina, Australia, Brazil, Bulgaria, China, France, India, Japan, Sweden (VLLW only), Ukraine, UK, Scotland, and US. Another type of near-surface disposal includes temporary and/or permanent placement within a shaft or tile hole, which has been employed in Australia, India, and Scotland.

Many countries also utilize surface disposal options, such as engineered concrete vault-type structures with multi-layer engineered and natural barriers (also referred to as landfill embankments), which are typically built using a modular design. Countries that have or currently use surface vaults for LILW include Bulgaria, China, France, India, Ukraine, UK, and US. Liquid LLW in the Ukraine is stored in dedicated cylindrical tanks made of stainless steel and coated with reinforced concrete. Another surface option, practiced in Russia, involves the use of ground concrete platforms for the long-term interim storage of nuclear reactor compartments.

Shallow underground geologic disposal, ranging from 50 to $130 \mathrm{~m}$ deep, has been used in Korea and Sweden. Korea's design involves engineered rock caverns in a stable and homogeneous granite rock formation. Sweden has four mined rock vaults and a concrete silo surrounded by multiple natural and engineered barriers. Deep geologic disposal is used in both Germany and Russia. In Germany, waste is stored in pre-existing deep geological formations, such as former mine chambers (250 - 3,400 m depth), with the option to recover waste using the help of various mining technique. Russia utilizes a deep-well injection method, which pumps liquid radioactive wastes under pressure into deep underground porous rock formations that typically range from 150 - $500 \mathrm{~m}$ deep, but can go as deep as 2,600 m.

Interim temporary storage or disposal for LILW is commonly used in the absence of permanent storage or as a temporary solution until waste can be transported to a permanent facility. Facilities maybe located near the point of production (e.g., NPP sites), or in purpose built centralized facilities. Storage and disposal option can be located in either in-ground structures or above-ground engineered facilities and include sand trenches, clay lined trenches, engineered bunkers, trench-type warehouses, metal tanks, reinforced concrete disposal cells, and specially designed buildings. Counties that utilize these types of interim facilities include Argentina, Armenia, Australia, Belgium, Brazil, Bulgaria, Canada, Japan, Korea, Russia, Ukraine, UK, and US. Sweden uniquely uses a crystalline bedrock cavern with a minimum rock cover of $20 \mathrm{~m}$ to temporary store LILW.

Historic sea-based disposal of LLW has been also been used by Belgium, Russia, Sweden, and the UK. Sweden was the first of these countries to suspend (1960s) and subsequently ban (1971) these activities. Both Belgium and the UK used this method of disposal into the early 1980s; whereas, Russia continued the practice of sea dumping until 1993. Other historical 
methods of disposal, which are no longer in practice, include the US practice of deep well injection (referred to as Hydrofract).

Types of Facilities

Currently, there are seven countries with an open and operating national repository for LLW. Bulgaria operates the Novi Han Repository for permanent disposal of non-nuclear power generated LLW. China has two repositories (Northwest and Beilong) for LILW from the nuclear industry, institutions, and NPPs, along with a national centralized storage facility for disused radioactive sources that are primarily nuclear industry legacy waste. France operates the Centre de l'Aube for current and historical LILW and the Centre de Morvilliers (CSTFA) for VLLW primarily originating from nuclear facility decommissioning and dismantling. India has seven Near Surface Disposal Facilities (NSDF) across the country co-located with nuclear power and research reactor complexes for disposal of LILW. The Rokkasho-Mura Disposal Center acts as the principal disposal center for Japanese LLW. Sweden operates the Swedish Final Repository (SFR-1) for short-lived LILW primarily from the country's nuclear reactors, along with final repositories for short-lived VLLW that located at the operating NPPs in Ringhals, Forsmark and Oskarshamn, as well as the Studsvik research site. Finally, the Drigg Low Level Waste Repository (LLWR) provides for disposal of LLW from non-nuclear power sector facilities, as well as nuclear sites in the UK.

The remaining eleven countries summarized in this report have no permanent operating national repository available for all of its LLW. These countries include Argentina, Armenia, Australia, Belgium, Brazil, Canada, Korea, Germany, Russia, Ukraine, and the US. Of these countries, Russia, Ukraine, and the US do have national repositories that conditionally accept waste. For example, Russia has a land-based national repository for areas within northwest Russia only, and Ukraine operates a repository for waste originating within the Chernobyl exclusion zone. The US, which has nine total operating LLW repositories, has limitation for acceptance based on classification, sector (e.g., governmental or commercial) and origin location of waste (e.g., state or compact).

Fortunately, many countries, including the majority of those with no current operating national LLW repository, have future plans for a permanent disposal facility. Argentina and Armenia are in the early planning stages of a near surface repository at a yet to be determined site. Australia is currently in the site selection process for a national radioactive waste repository for LLW, short-lived ILW, and conditioned long-lived ILW; facilities that are to be co-located at a yet undetermined site. The Belgium LLW surface disposal facility, to be located at Dessel, is currently in the design phase, with full operation is expected by the year 2016. Plans for a Brazilian national waste repository for LILW are under development and Government review. Bulgaria has selected a priority location at the Radiana site for its national repository, but has not begun the full design process.

Canada has initiatives underway for a Deep Geologic Repository (DGR) on the BNPD site, designed to hold current and future LILW from OPG's 20 reactors, that is currently in the environmental assessment and licensing phase with full service operation beginning around 2017-18. Studies and initial evaluations are also underway for a deep repository at the CRL site for AECL's inventory of solid LILW. In addition, Canada has plans for two historic LLW disposal facilities currently in the environmental assessment and regulatory review phase, each expected to be completed in late 2011. 
France is undergoing site selection and preliminary investigations for a long-lived LLW nearsurface disposal center with operation planned for 2019. Construction is under way in Germany for a LILW repository at the former Konrad iron ore mine in Salzgitter (at depths between 800 $1,300 \mathrm{~m}$ ), which is expected to be operational between 2013 and 2014. Germany is also in the early planning and investigational stages for a repository in a rock salt dome $(250-3,400 \mathrm{~m}$ deep) at the Gorleben site that will accept all types of radioactive waste (including HLW); however, development is currently in a moratorium period. Japan has plans under development to construct a sub-surface disposal facility (50-100 m deep) at Rokkasho site for relatively higher level of LLW; geological investigations were completed in March 2006. Korea's national repository, the Wolsong LILW Disposal Center, is expected to open in 2012.

In Russia, construction is progressing (completion at the end of 2014) on The Regional Centre for Conditioning and Storage of Radioactive Waste (TsKDKh RAO), located adjacent to the Sayda Bay storage facility site, and intended to completely finish the disposal chain for nuclear submarines in the northwest of Russia. In addition, tentative plans exist in Russia for the development of new and modernization of existing radioactive waste repositories, including refurbishment of more than 15 storage facilities, establishment of four to six regional waste repositories for LILW containing short-lived radionuclides, and construction of one or two repositories for wastes containing long-lived radionuclides.

Sweden has planned extension of the existing SFR-1 facility at Forsmark for disposal of decommissioning waste resulting from the nation's NPPs, which is expected to start operation in 2020, at the earliest. The Ukraine has developed plans and completed a feasibility study for Stage II of the Vektor complex (construction of ENSDF was Stage I) that will include facilities for the disposal of short-lived LILW from the Chernobyl site and other Ukrainian NPPs, disposal or long-term storage of non-nuclear power enterprise waste, processing and long-term storage of long-lived and HLW (including nuclear fuel processing waste and spent radiation sources). Proposed expansion of the Drigg LLWR in the UK is expected to begin construction in 2013, and run through 2079. In addition, plans are being developed in the UK for a VLLW Disposal Service to support producers of this type of waste. In Scotland, a proposed solid LLW nearsurface disposal facility is being planned adjacent to the existing Dounreay site, with construction due to begin in 2012. Finally, the US has a fourth commercial and federal LLW facility currently under construction in Texas. This facility was licensed in 2009 for Class A, B, and $\mathrm{C}$ waste, but will accept waste from Federal facilities and Texas Compact States only. 
Table 6. Summary of international Waste Management Practice, Facilities, and Initiatives

\begin{tabular}{|c|c|c|c|}
\hline Country & Existing Facilities & Waste Management Practices & Initiatives \\
\hline \multirow[t]{2}{*}{ Argentina } & $\begin{array}{l}\text { Ezeiza Radioactive Waste Management } \\
\text { Area (EMA): located at Ezeiza Atomic } \\
\text { Center (EAC) site; permanently suspended } \\
\text { operation in 2006. }\end{array}$ & $\begin{array}{l}\text { Near surface engineered trenches and } \\
\text { underground concrete pits for solid and } \\
\text { liquid LLW wastes. Temporary storage for } \\
\text { ILW in a specially designed building. }\end{array}$ & \multirow[t]{2}{*}{$\begin{array}{l}\text { Permanent LLW and ILW repositories are to be co- } \\
\text { located at a yet to be determined site. The ILW } \\
\text { facility would likely be of a near-surface monolithic } \\
\text { concrete or sub-surface geologic type. }\end{array}$} \\
\hline & $\begin{array}{l}\text { Atucha-1 and Embalse NPP sites: storage } \\
\text { facilities for LILW. }\end{array}$ & $\begin{array}{l}\text { Temporary on-site storage in above ground } \\
\text { tanks or buildings. }\end{array}$ & \\
\hline Armenia & Metsamor NPP site: storage of LLW & $\begin{array}{l}\text { Temporary on-site storage in above ground } \\
\text { compartments. }\end{array}$ & $\begin{array}{l}\text { Proposal in process for the new LILW burial site; } \\
\text { details have yet to be finalized. }\end{array}$ \\
\hline \multirow[t]{2}{*}{ Australia } & $\begin{array}{l}\text { Multiple interim storage facilities: more than } 100 \\
\text { located throughout the country; no permanent } \\
\text { national repository. }\end{array}$ & $\begin{array}{l}\text { Ranges from purpose built decontamination } \\
\text { facilities and waste stores, to temporary } \\
\text { facilities for material in transit. }\end{array}$ & \multirow{2}{*}{$\begin{array}{l}\text { Site selection in process for a national radioactive } \\
\text { waste repository for LLW, short-lived ILW, and } \\
\text { conditioned long-lived ILW; facilities are to be co- } \\
\text { located. LLW and short-lived ILW will be disposed } \\
\text { of in shallow engineered trenches. Conditioned } \\
\text { long-lived ILW facility is planned as an engineered } \\
\text { above-ground building. }\end{array}$} \\
\hline & $\begin{array}{l}\text { Regional disposal facilities: limited access } \\
\text { based on origin of waste; e.g., Mt Walton East } \\
\text { Intractable Waste Disposal Facility (IWDF). }\end{array}$ & $\begin{array}{l}\text { Near-surface shaft or trench burial } \\
\text { technique. }\end{array}$ & \\
\hline \multirow[t]{2}{*}{ Belgium } & $\begin{array}{l}\text { Multiple interim storage facilities: two for LLW } \\
\text { and three for ILW. }\end{array}$ & Temporary above ground storage buildings. & \multirow{2}{*}{$\begin{array}{l}\text { LLW surface disposal facility located at Dessel is in } \\
\text { the design phase; full operation is expected by the } \\
\text { year } 2016 \text {. Facility is designed in a progressive, } \\
\text { flexible, and reversible manner with fully engineered } \\
\text { barriers and draining systems. }\end{array}$} \\
\hline & $\begin{array}{l}\text { Sea disposal: practice suspended in the early } \\
\text { eighties. }\end{array}$ & Permanent disposal of conditioned LLW. & \\
\hline \multirow[t]{3}{*}{ Brazil } & Angra NPP site: storage of solid LILW. & $\begin{array}{l}\text { Temporary on-site storage in above ground } \\
\text { buildings, to be later removed to a final } \\
\text { repository. }\end{array}$ & \multirow{3}{*}{$\begin{array}{l}\text { Plans for a national waste repository for LILW are } \\
\text { under development and Government review. Time } \\
\text { frame for construction of the first repository module } \\
\text { is estimated to be } 5 \text { years following final site } \\
\text { selection and approval. }\end{array}$} \\
\hline & $\begin{array}{l}\text { Multiple interim storage facilities: located at } \\
\text { CNEN research institutes and near other } \\
\text { smaller generators. }\end{array}$ & Temporary storage. & \\
\hline & $\begin{array}{l}\text { Abadia de Goiás facility: storage for waste } \\
\text { collected from the Goiânia accident; officially } \\
\text { closed with environmental restoration } \\
\text { performed }\end{array}$ & $\begin{array}{l}\text { Shallow engineered storage facilities for } \\
\text { short lived LLW. }\end{array}$ & \\
\hline \multirow[t]{2}{*}{ Bulgaria } & Kozloduy NPP site: storage facility for LILW. & $\begin{array}{l}\text { Temporary on-site surface disposal in } \\
\text { reinforced concrete trench-type and storage } \\
\text { in warehouse buildings. }\end{array}$ & \multirow{2}{*}{$\begin{array}{l}\text { Site selection in process the National Repository for } \\
\text { RAW (NRRAW); priority location is the Radiana site. } \\
\text { Repository will be designed as a near surface multi- } \\
\text { barrier modular engineered trench facility intended } \\
\text { for disposal of conditioned and packaged short-lived } \\
\text { LILW. }\end{array}$} \\
\hline & $\begin{array}{l}\text { Novi Han Repository: located in Losen } \\
\text { Mountain; permanent repository for non-nuclear } \\
\text { power generated wastes. }\end{array}$ & $\begin{array}{l}\text { Trench and vault-type surface disposal } \\
\text { options with multilayer engineered barriers } \\
\text { for LILW. }\end{array}$ & \\
\hline
\end{tabular}




\begin{tabular}{|c|c|c|c|}
\hline Country & Existing Facilities & Waste Management Practices & Initiatives \\
\hline \multirow[t]{4}{*}{ Canada } & $\begin{array}{l}\text { Multiple interim storage facilities: NPPs and } \\
\text { waste producers manage and operate these } \\
\text { facilities; no permanent national repository. }\end{array}$ & $\begin{array}{l}\text { Temporary long-term storage in such a way } \\
\text { that it can be retrieved when permanent } \\
\text { facilities become available. }\end{array}$ & \multirow{2}{*}{$\begin{array}{l}\text { Initiatives are ongoing for a Deep Geologic } \\
\text { Repository (DGR), planned on the BNPD site } \\
\text { beneath the WWMF ( } 650 \text { - } 700 \text { m depth), and } \\
\text { designed to hold current and future LILW from } \\
\text { OPG's } 20 \text { reactors. Environmental assessment and } \\
\text { licensing expected to take } 6-8 \text { years, followed by } \\
\text { issuance of a construction license in } 2012 \text { and full } \\
\text { service operation beginning around } 2017-18 \text {. }\end{array}$} \\
\hline & $\begin{array}{l}\text { Western Waste Management Facility (WWMF): } \\
\text { located at the Bruce Nuclear Power } \\
\text { Development (BNPD) site in Kincardine, } \\
\text { Ontario; stores the majority of LILW from } \\
\text { commercial nuclear reactor operations. }\end{array}$ & $\begin{array}{l}\text { Temporary LLW storage in above ground } \\
\text { buildings. Temporary ILW is storage in } \\
\text { either in-ground structures or above-ground } \\
\text { engineered, including quadricells, } \\
\text { containers, trenches, and tile holes. }\end{array}$ & \\
\hline & $\begin{array}{l}\text { AECL Research sites: LILW from research and } \\
\text { development is stored either at two laboratory } \\
\text { sites, Chalk River Laboratories (CRL) or } \\
\text { Whiteshell Laboratories (shutdown), or at three } \\
\text { research reactor sites. }\end{array}$ & $\begin{array}{l}\text { Temporary on-site LLW storage in sand } \\
\text { trenches, engineered bunkers, and shielded } \\
\text { above ground buildings. Temporary ILW } \\
\text { storage in in-ground concrete bunkers or } \\
\text { tile holes. }\end{array}$ & $\begin{array}{l}\text { Studies and initial evaluations are proceeding for a } \\
\text { deep repository at the CRL site for AECL's inventory } \\
\text { of solid LILW. }\end{array}$ \\
\hline & $\begin{array}{l}\text { Welcome Waste Management Facility: located } \\
\text { in Port Hope; repository for historic LLW. }\end{array}$ & Temporary storage. & $\begin{array}{l}\text { Port Hope Area Initiative (PHAI) has two projects } \\
\text { underway: Port Hope Project (planned as an } \\
\text { extended site of the existing facility) and Port } \\
\text { Granby Project. Both proposed facilities would be } \\
\text { above ground disposal mounds with multiple layers } \\
\text { of natural and engineered materials. Both projects } \\
\text { are in the environmental assessment and regulatory } \\
\text { review phase, expected completion in late } 2011 \text {. }\end{array}$ \\
\hline \multirow[t]{5}{*}{ China } & $\begin{array}{l}\text { On-site treatment and storage: located at each } \\
\text { NPP and most the large-scale nuclear facilities } \\
\text { for their own waste. }\end{array}$ & $\begin{array}{l}\text { Permanent on-site disposal for large } \\
\text { volumes and VLLW via emplacement in } \\
\text { engineered near surface structures. }\end{array}$ & \multirow[t]{5}{*}{ None identified. } \\
\hline & $\begin{array}{l}\text { National Urban Radioactive Waste Storage } \\
\text { Repositories: } 23 \text { repositories completed and } \\
4 \text { facilities incomplete as of } 2009 \text {; centralized } \\
\text { management and regulation for LILW. }\end{array}$ & Temporary storage facilities. & \\
\hline & $\begin{array}{l}\text { Provincial Radioactive Waste Storages: for } \\
\text { waste produced outside of the nuclear power } \\
\text { industry; waste actively is being transferred to } \\
\text { the national Urban Repositories; } 4 \text { provincial } \\
\text { storages were been capped by } 2009 \text {. }\end{array}$ & Temporary storage facilities. & \\
\hline & $\begin{array}{l}\text { Regional disposal: LILW from the nuclear } \\
\text { industry, institutions, and NPPs at two } \\
\text { facilities - Northwest LILW Repository (near } \\
\text { Yumen) and Beilong LILW Repository (located } \\
\text { near Daya Bay NPP in South China). }\end{array}$ & $\begin{array}{l}\text { Permanent near-surface disposal using } \\
\text { underground and partial underground } \\
\text { methods (e.g., concrete vaults), with a } \\
\text { multilayer combination of engineered and } \\
\text { natural barriers on top for LILW. }\end{array}$ & \\
\hline & $\begin{array}{l}\text { National centralized storage facility for disused } \\
\text { radioactive sources: primarily used for nuclear } \\
\text { industry legacy waste. }\end{array}$ & & \\
\hline
\end{tabular}




\begin{tabular}{|c|c|c|c|}
\hline Country & Existing Facilities & Waste Management Practices & Initiatives \\
\hline \multirow[t]{3}{*}{ France } & $\begin{array}{l}\text { Centre de la Manche: located at Digulleville, in } \\
\text { Normandy; national repository for current and } \\
\text { historical LILW; operated until July 1994; } \\
\text { currently in monitoring and surveillance phase. }\end{array}$ & $\begin{array}{l}\text { Permanent near-surface disposal. Past use } \\
\text { of direct burial in earthen or concrete } \\
\text { trenches and disposal in prefabricated } \\
\text { reinforced concrete monoliths. Protective } \\
\text { cap installed over disposal areas at closure. }\end{array}$ & \multirow{3}{*}{$\begin{array}{l}\text { Site selection and preliminary investigations under } \\
\text { development for a long-lived LLW disposal center. } \\
\text { Final repository is likely to be a near-surface type } \\
\text { constructed in clay. Operation planned for } 2019 . \\
\text { Intent to establish a commercially viable system to } \\
\text { recycle materials, notably steel and concrete, } \\
\text { recovered during decommissioning of nuclear } \\
\text { facilities in non-nuclear applications within the } \\
\text { nuclear industry. }\end{array}$} \\
\hline & $\begin{array}{l}\text { Centre de l'Aube: located at Digulleville, in } \\
\text { Normandy; national repository for current and } \\
\text { historical LILW; took over when in Centre de la } \\
\text { Manche shut down. }\end{array}$ & $\begin{array}{l}\text { Permanent surface disposal in engineered } \\
\text { concrete vaults. }\end{array}$ & \\
\hline & $\begin{array}{l}\text { Centre de Morvilliers (CSTFA): located near the } \\
\text { Centre de l'Aube around Troyes; for VLLW } \\
\text { primarily originating from nuclear facility } \\
\text { decommissioning and dismantling }\end{array}$ & $\begin{array}{l}\text { Permanent disposal near-surface lined } \\
\text { earthen trenches. }\end{array}$ & \\
\hline \multirow[t]{3}{*}{ Germany } & $\begin{array}{l}\text { Morsleben Repository for Radioactive Waste } \\
\text { (ERAM): located in East Germany at a former } \\
\text { salt dome; for LILW from nuclear power plants } \\
\text { as well as waste from research, medical, and } \\
\text { industrial applications; closed in } 1998 \text { and is } \\
\text { currently being decommissioned. }\end{array}$ & $\begin{array}{l}\text { Deep geologic disposal ( } 400-600 \text { m deep) } \\
\text { in former mine chambers. Currently being } \\
\text { stabilized with a special-purpose concrete. }\end{array}$ & \multirow{3}{*}{$\begin{array}{l}\text { Investigation for a repository in a rock salt dome } \\
(250-3,400 \text { m deep) at the Gorleben site that will } \\
\text { accept all types of radioactive waste (including } \\
\text { HLW). Development is currently in a moratorium } \\
\text { period, pending further examination of alternative } \\
\text { sites with favorable geological settings and } \\
\text { conclusion of safety analyses. } \\
\text { Construction underway for a LILW repository at the } \\
\text { former Konrad iron ore mine in Salzgitter. } \\
\text { Encasement drifts and waste disposal areas (at } \\
\text { depths between } 800-1,300 \text { m) could be backfilled } \\
\text { and sealed in the future. Expected to be operational } \\
\text { between } 2013 \text { and } 2014 \text {. }\end{array}$} \\
\hline & \multirow[b]{2}{*}{$\begin{array}{l}\text { Asse Research Mine and Repository: located } \\
\text { in West Germany in an old potash mine and } \\
\text { salt dome in Lower Saxony; for LILW disposal } \\
\text { by federal and state agencies; emplacement } \\
\text { halted in 1978, although research and } \\
\text { development was performed until 1992; } \\
\text { currently closed and is waste being removed. }\end{array}$} & \multirow{2}{*}{$\begin{array}{l}\text { Deep geologic disposal (up to } 750 \text { m deep) } \\
\text { in former mine chambers. }\end{array}$} & \\
\hline & & & \\
\hline India & $\begin{array}{l}\text { Near Surface Disposal Facilities (NSDF): seven } \\
\text { facilities across the country co-located with } \\
\text { nuclear power and research reactor complexes } \\
\text { (Trombay, Maharashtra; Tarapur, } \\
\text { Maharashtra; Kota, Rajasthan; Kalpakkam, } \\
\text { Tamil Nadu; Narora, Uttar Pradesh; Kakrapar, } \\
\text { Gujrat; Kaiga, Karnataka); for disposal of LILW. }\end{array}$ & $\begin{array}{l}\text { Permanent disposal is sub-divided into } \\
\text { zones for the various types of wastes and } \\
\text { employs near-surface multiple barrier } \\
\text { approach. Disposal cells for a typical LILW } \\
\text { facility include stone-lined earth trenches } \\
\text { (mainly LLW), reinforced concrete trenches/ } \\
\text { vaults, and steel lined concrete tile holes. }\end{array}$ & \\
\hline \multirow[t]{3}{*}{ Japan } & $\begin{array}{l}\text { Rokkasho-Mura Disposal Center: part of the } \\
\text { Japan Nuclear Fuel Limited (JNFL) nuclear fuel } \\
\text { cycle facilities; principal center for LLW. }\end{array}$ & $\begin{array}{l}\text { Permanent disposal in a near surface } \\
\text { engineered concrete pits. }\end{array}$ & \multirow{3}{*}{$\begin{array}{l}\text { Plans under development to construct a sub-surface } \\
\text { disposal facility (50 - } 100 \text { m deep) at Rokkasho site } \\
\text { for relatively higher level of LLW. Geological } \\
\text { investigations were completed in March } 2006 \text {. }\end{array}$} \\
\hline & $\begin{array}{l}\text { Tokai Research and Development Center: } \\
\text { located at Nuclear Science Research Institute } \\
\text { of JAEA; for VLLW; has been at the } \\
\text { preservation stage since October } 1997 .\end{array}$ & Permanent disposal in shallow trenches. & \\
\hline & NPP sites: storage facilities for LLW. & Temporary on-site storage. & \\
\hline
\end{tabular}




\begin{tabular}{|c|c|c|c|}
\hline Country & Existing Facilities & Waste Management Practices & Initiatives \\
\hline \multirow[t]{3}{*}{ Korea } & $\begin{array}{l}\text { The Wolsong LILW Disposal Center: located in } \\
\text { Gyeongju near the Wolsong NPP; for storage } \\
\text { and disposal of LILW; storage operation } \\
\text { commenced in December 2010; underground } \\
\text { repository expected to be operational in } 2012 \text {. }\end{array}$ & $\begin{array}{l}\text { Temporary on-site storage in outdoor } \\
\text { areas. }\end{array}$ & \multirow[t]{3}{*}{$\begin{array}{l}\text { Construction underway for underground repository } \\
(80-130 \text { m below the surface) portion of the } \\
\text { Wolsong LILW Disposal Center. The design } \\
\text { involves shallow geological disposal in a stable and } \\
\text { homogeneous granite rock formation using } \\
\text { engineered rock caverns (silos). }\end{array}$} \\
\hline & NPP sites: storage facilities for LLW. & Temporary on-site storage. & \\
\hline & $\begin{array}{l}\text { Nuclear Environment Technology Institute } \\
\text { (NETEC): for radioisotope related waste } \\
\text { resulting from various medical, industrial, } \\
\text { educational, and research applications. }\end{array}$ & Temporary on-site storage. & \\
\hline \multirow[t]{6}{*}{ Russia } & $\begin{array}{l}\text { Sayda Bay Long-Term Storage Facility: } \\
\text { located on the coastal strip of the Kola } \\
\text { Peninsula; land-based interim storage facility } \\
\text { for all LILW nuclear waste from radioactive } \\
\text { elements in northwest Russia; }\end{array}$ & \begin{tabular}{|l|} 
Long-term storage of decommissioned \\
nuclear submarines, surface vessels, and \\
their components awaiting dismantlement. \\
Vessels and components (currently floating) \\
are dismantled and scrap metal is \\
separated. Concrete platforms provide the \\
long-term interim storage area for nuclear \\
reactor compartments.
\end{tabular} & \multirow{3}{*}{$\begin{array}{l}\text { Construction progressing on The Regional Centre } \\
\text { for Conditioning and Storage of Radioactive Waste } \\
\text { (TsKDKh RAO), located adjacent to the Sayda Bay } \\
\text { storage facility site. The Centre is intended to } \\
\text { completely finish the disposal chain for nuclear } \\
\text { submarines in the northwest of Russia. The design } \\
\text { includes a complex for the acceptance, } \\
\text { decontamination, conditioning, and packaging of } \\
\text { radioactive materials; along with the assessment of } \\
\text { material that could potentially be recycled or reused } \\
\text { following treatment. The facility is scheduled for } \\
\text { completion at the end of } 2014 \text {. }\end{array}$} \\
\hline & $\begin{array}{l}\text { Nuclear Ships: sea-based storage for LILW on } \\
\text { vessels referred to as floating maintenance } \\
\text { bases (FMB); primary holding place is at } \\
\text { Sayda Bay. }\end{array}$ & $\begin{array}{l}\text { Transport and temporary storage on the } \\
\text { same vessels previously used for collection } \\
\text { and dumping of waste. }\end{array}$ & \\
\hline & Sea disposal: practice prohibited in July 1993. & $\begin{array}{l}\text { Permanent disposal of LLW and nuclear } \\
\text { ship reactors via dumping into the Baltic } \\
\text { and Arctic Seas, as well as northern Pacific. }\end{array}$ & \\
\hline & $\begin{array}{l}\text { Multiple temporary storage and disposal sites: } \\
\text { more than 1,400 facilities throughout the } \\
\text { country typically located near the point of } \\
\text { production (e.g., Mayak nuclear complex); for } \\
\text { storage of LILW; no permanent land-based } \\
\text { national repository exists for areas outside of } \\
\text { northwest Russia. }\end{array}$ & $\begin{array}{l}\text { Disposal of solid and solidified liquid LILW } \\
\text { is typically through near-surface burial in } \\
\text { clay lined trenches, without prior } \\
\text { processing. }\end{array}$ & \multirow[t]{3}{*}{$\begin{array}{l}\text { Tentative plans exist, as of } 2008 \text {, to develop new } \\
\text { and modernize existing radioactive waste } \\
\text { repositories. Included is the refurbishing of more } \\
\text { than } 15 \text { waste storage facilities, establishment of } \\
\text { four to six regional waste repositories for LILW } \\
\text { containing short-lived radionuclides, and } \\
\text { construction of one or two repositories for wastes } \\
\text { containing long-lived radionuclides. }\end{array}$} \\
\hline & $\begin{array}{l}\text { Radon repositories: } 16 \text { to } 30 \text { storage facilities } \\
\text { located throughout Russia (many filled to } \\
\text { capacity); for non-nuclear fuel cycle LILW. }\end{array}$ & $\begin{array}{l}\text { Disposal in near-surface or above-grade } \\
\text { reinforced concrete disposal cells. }\end{array}$ & \\
\hline & $\begin{array}{l}\text { Deep geologic disposal: more than } 20 \text { sites } \\
\text { located throughout Russia (e.g., Seversk and } \\
\text { Zheleznogorsk). }\end{array}$ & $\begin{array}{l}\text { Permanent disposal of liquid radioactive } \\
\text { waste using deep-well injection method, } \\
\text { which pumps wastes under pressure into } \\
\text { deep underground porous rock formations. } \\
\text { Wells typically range from } 150-500 \mathrm{~m} \\
\text { deep, but can go as deep as } 2,600 \mathrm{~m} \text {. }\end{array}$ & \\
\hline
\end{tabular}




\begin{tabular}{|c|c|c|c|}
\hline Country & Existing Facilities & Waste Management Practices & Initiatives \\
\hline \multirow[t]{4}{*}{ Sweden } & $\begin{array}{l}\text { Swedish Final Repository (SFR-1): situated at } \\
\text { the Forsmark NPP site in the crystalline } \\
\text { bedrock at depth of } 50 \mathrm{~m} \text { below the bottom of } \\
\text { the Baltic Sea; for short-lived LILW primarily } \\
\text { from reactors, but small amounts from other } \\
\text { operations. }\end{array}$ & $\begin{array}{l}\text { It has four mined rock vaults, one for LLW } \\
\text { waste and three for concrete tanks and ILW } \\
\text { waste. ILW is also (and primarily) disposed } \\
\text { of in a concrete silo. The facility is } \\
\text { surrounded by multiple natural and } \\
\text { engineered barriers. When closed, the } \\
\text { storage rooms and tunnels will be backfilled } \\
\text { and plugged to both mechanically and } \\
\text { hydraulically seal the chambers. }\end{array}$ & \multirow[t]{4}{*}{$\begin{array}{l}\text { Planned extension of the existing SFR-1 facility at } \\
\text { Forsmark for disposal of decommissioning waste } \\
\text { resulting from the nation's NPPs. The facility } \\
\text { (SFR-3) would eventually also handle long-lived } \\
\text { LILW, via placement at a greater depth. Test drilling } \\
\text { in preparation for the extension was performed in } \\
2009 \text {; results are currently under review and } \\
\text { analysis. The goal is to submit a permit application } \\
\text { for the extension in } 2013 \text {, with the planned start of } \\
\text { operation in } 2020 \text {, at the earliest. }\end{array}$} \\
\hline & $\begin{array}{l}\text { AM facility: located at the Studsvik research } \\
\text { site; for storage of LILW from non-nuclear } \\
\text { power applications and decommissioning of old } \\
\text { nuclear facilities. }\end{array}$ & $\begin{array}{l}\text { Temporary storage in a crystalline bedrock } \\
\text { cavern with a minimum rock cover of } 20 \mathrm{~m} \text {. }\end{array}$ & \\
\hline & $\begin{array}{l}\text { Facilities for short-lived VLLW facilities: located } \\
\text { at the operating NPPs in Ringhals, Forsmark } \\
\text { and Oskarshamn, as well as the Studsvik } \\
\text { research site. }\end{array}$ & Permanent disposal by shallow land burial. & \\
\hline & $\begin{array}{l}\text { Sea disposal: practice suspended in the early } \\
\text { sixties; banned in } 1971 .\end{array}$ & $\begin{array}{l}\text { Permanent disposal of LLW in Swedish } \\
\text { territorial waters, as well as in the Atlantic. }\end{array}$ & \\
\hline \multirow[t]{4}{*}{ Ukraine } & $\begin{array}{l}\text { Chernobyl exclusion zone: waste resulting } \\
\text { from the Chernobyl disaster is located in } \\
\text { radwaste disposal sites (RWDS), radwaste } \\
\text { interim confinement sites (RICS), and more } \\
\text { than } 800 \text { points of temporary localization in the } \\
\text { exclusion area. }\end{array}$ & $\begin{array}{l}\text { Temporary storage established under } \\
\text { extreme post-accident conditions. The } \\
\text { majority of these areas do not meet current } \\
\text { regulatory requirements. }\end{array}$ & \multirow[t]{2}{*}{$\begin{array}{l}\text { Plans exist to modernize the Buryakivka RWDS and } \\
\text { create additional disposal capacities. Initial step is to } \\
\text { perform an operational and long-term safety } \\
\text { reassessment that takes into account all the } \\
\text { radioactive waste disposed (or planned to be } \\
\text { disposed) and state of existing protective barriers. }\end{array}$} \\
\hline & $\begin{array}{l}\text { Buryakivka RWDS: last active and functioning } \\
\text { RWDS; part of the State Specialized Enterprise } \\
\text { (SSE) Complex for managing the radioactive } \\
\text { waste generated from Chernobyl accident. }\end{array}$ & $\begin{array}{l}\text { Disposal in near-surface trench-type } \\
\text { facilities. }\end{array}$ & \\
\hline & $\begin{array}{l}\text { Engineered Near-Surface Disposal Facility } \\
\text { (ENSDF): located at the SSE Technocenter } \\
\text { (Vektor); for disposal of conditioned solid LILW } \\
\text { from the ICSRM and other sources of within the } \\
\text { Chernobyl exclusion zone. }\end{array}$ & $\begin{array}{l}\text { Disposal of waste packages into modular } \\
\text { structure above ground concrete disposal } \\
\text { units. }\end{array}$ & \multirow{2}{*}{$\begin{array}{l}\text { Plans and feasibility study for Stage II of the Vektor } \\
\text { complex (construction of ENSDF was Stage I) have } \\
\text { been endorsed by the Cabinet of Ministers of } \\
\text { Ukraine. Facilities include: processing LILW } \\
\text { (including long-lived); disposal of short-lived LILW } \\
\text { from the Chernobyl site and other Ukrainian NPPs; } \\
\text { disposal or long-term storage of non-nuclear power } \\
\text { enterprise waste; processing and long-term storage } \\
\text { of long-lived and HLW (including nuclear fuel } \\
\text { processing waste and spent radiation sources). }\end{array}$} \\
\hline & $\begin{array}{l}\text { TRO } 1 \text { and TRO-2 disposal repositories: } \\
\text { located at the Vektor Complex; for LILW. }\end{array}$ & $\begin{array}{l}\text { Disposal in reinforced concrete containers } \\
\text { and in bulk. }\end{array}$ & \\
\hline
\end{tabular}




\begin{tabular}{|c|c|c|c|}
\hline Country & Existing Facilities & Waste Management Practices & Initiatives \\
\hline \multirow[t]{5}{*}{$\begin{array}{l}\text { Ukraine } \\
\text { (cont'd.) }\end{array}$} & $\begin{array}{l}\text { State Interregional Specialized Plants (SISPS): } \\
\text { six management facilities (Kyiv, Odessa, } \\
\text { Kharkiv, Dnipropetrovsk, Lviv, Donetsk); for } \\
\text { LILW generated by non-nuclear power sector } \\
\text { enterprises. }\end{array}$ & $\begin{array}{l}\text { Disposal of solid LILW in engineered } \\
\text { surface structures. Liquid LILW produced } \\
\text { by the SISPs is stored dedicated cylindrical } \\
\text { tanks made of stainless steel and coated } \\
\text { with reinforced concrete. Donetsk, does } \\
\text { not operate storage facilities; it merely } \\
\text { collects LILW in the region and performs } \\
\text { decontamination services. }\end{array}$ & \\
\hline & $\begin{array}{l}\text { Research reactor sites: two facilities at SUNEI } \\
\text { (Sevastopol) and NASU INR (Kyiv); for } \\
\text { operational LILW. }\end{array}$ & $\begin{array}{l}\text { Temporary storage of solid LILW at } \\
\text { facilities on-site until transported to the } \\
\text { central waste management facility (i.e., } \\
\text { Odessa or Kyiv SISP). Liquid LILW is } \\
\text { collected and temporary stored in metal } \\
\text { tanks awaiting further treatment. }\end{array}$ & \\
\hline & $\begin{array}{l}\text { NPP sites: four operating facilities at } \\
\text { Zaporizhzhya (ZNPP), Rivne (RNPP), South } \\
\text { Ukraine (SUNPP), and Khmelnitsky (KNPP); for } \\
\text { operational LILW. }\end{array}$ & $\begin{array}{l}\text { Temporary storage of solid LILW in } \\
\text { reinforced concrete boxes. }\end{array}$ & \\
\hline & $\begin{array}{l}\text { Chernobyl NPP (ChNPP) site: storage facilities } \\
\text { for LILW accumulated during the operation of } \\
\text { the ChNPP; constructed according to the } \\
\text { original plant designs; presently closed. }\end{array}$ & $\begin{array}{l}\text { Temporary on-site modules equipped with } \\
\text { protection systems. }\end{array}$ & \\
\hline & $\begin{array}{l}\text { Industrial Complex for Radwaste Management } \\
\text { (ICSRM): constructed at the ChNPP site to } \\
\text { manage LILW long-term. }\end{array}$ & $\begin{array}{l}\text { Temporary storage facilities of solid and } \\
\text { liquid LILW and HLW; retrieval and } \\
\text { processing of solid LILW from the existing } \\
\text { temporary storage; sorting of long-lived } \\
\text { and HLW solid waste for temporary } \\
\text { separate storage; and conditioning of } \\
\text { solid LILW, as required, before packaging } \\
\text { for final disposal. }\end{array}$ & \\
\hline
\end{tabular}




\begin{tabular}{|c|c|c|c|}
\hline Country & Existing Facilities & Waste Management Practices & Initiatives \\
\hline \multirow[t]{6}{*}{ United Kingdom } & $\begin{array}{l}\text { Drigg Low Level Waste Repository (LLWR): } \\
\text { located in Drigg in Cumbria; for disposal of LLW } \\
\text { from non-nuclear power sector facilities, as well } \\
\text { as nuclear sites. }\end{array}$ & $\begin{array}{l}\text { Permanent disposal in near-surface open } \\
\text { clay-lined trenches (until 1995) and } \\
\text { concrete engineered vaults with multilayer } \\
\text { engineered barriers. }\end{array}$ & $\begin{array}{l}\text { Proposed expansion of the LLWR, which consists of } \\
\text { the phased construction of five new vaults. } \\
\text { Construction is expected to begin in } 2013 \text {, and run } \\
\text { through } 2079 \text { with the closure and capping of the } \\
\text { last vault. In addition, the LLW Repository Ltd., } \\
\text { operators of the Drigg LLWR site, is developing a } \\
\text { VLLW Disposal Service to support producers of this } \\
\text { type of waste. }\end{array}$ \\
\hline & $\begin{array}{l}\text { Calder Landfill Extension Segregated Area: } \\
\text { located at Sellafield; for disposal of high volume } \\
\text { LLW primarily from demolition and construction } \\
\text { projects. }\end{array}$ & $\begin{array}{l}\text { Disposal using an engineered landfill on } \\
\text { site. }\end{array}$ & \\
\hline & $\begin{array}{l}\text { Clifton Marsh Landfill Site: located near } \\
\text { Preston, Lancashire; provides LLW disposal for } \\
\text { three nuclear facility sites (Springfields Fuels } \\
\text { Ltd; Sellafield Ltd [for Capenhurst]; and Urenco } \\
\text { UK Ltd); also receives household and industrial } \\
\text { waste from the Preston area. }\end{array}$ & $\begin{array}{l}\text { Disposal using an engineered landfill on } \\
\text { site. }\end{array}$ & \\
\hline & $\begin{array}{l}\text { Interim ILW storage facilities: located at } \\
\text { nuclear waste generating sites (e.g., NPPs of } \\
\text { the Magnox design; nuclear research sites at } \\
\text { Donnreay, Harwell, and Winfrith; and the } \\
\text { Atomic Weapons Establishments at } \\
\text { Aldermaston); for condition and storage of ILW. }\end{array}$ & $\begin{array}{l}\text { Temporary storage of conditioned ILW in } \\
\text { specially built facilities. }\end{array}$ & $\begin{array}{l}\text { There are no national facilities for disposal of ILW in } \\
\text { the UK, although a siting exercise for deep geologic } \\
\text { disposal was conducted and eventually rejected } \\
\text { during the 1990's. }\end{array}$ \\
\hline & $\begin{array}{l}\text { Dounreay site: located In Scotland; disposal of } \\
\text { LILW; closed in } 2005 .\end{array}$ & $\begin{array}{l}\text { Permanent disposal of LLW in a series of } \\
\text { six shallow pits. Temporary placement of } \\
\text { ILW within a shaft (until 1977); there is the } \\
\text { intention to recover this waste. }\end{array}$ & $\begin{array}{l}\text { Proposed solid LLW near-surface disposal facility is } \\
\text { being planned adjacent to the existing Dounreay } \\
\text { site. The proposed facility will consist of series of } \\
\text { shallow engineered vaults (maximum of six), with } \\
\text { multiple barrier caps. This facility will provide final } \\
\text { disposal for LLW primarily resulting from } \\
\text { decommissioning activities of the Dounreay site and } \\
\text { adjacent Vulcan Naval Reactor Test Establishment } \\
\text { (NRTE) site, along with relocation of LLW from } \\
\text { historical disposal pits. Contract notice for the } \\
\text { design and build of the first two vaults was issued in } \\
\text { March } 2010 \text {. Construction is due to begin in } 2012 \\
\text { using a phased approach to enable the } \\
\text { development and sizing of vaults tailored to actual } \\
\text { waste amounts. }\end{array}$ \\
\hline & Sea disposal: banned in 1983. & $\begin{array}{l}\text { Permanent disposal of LLW in deep ocean } \\
\text { sites along the coast of the UK and in the } \\
\text { North Atlantic. }\end{array}$ & \\
\hline
\end{tabular}




\begin{tabular}{|c|c|c|c|}
\hline Country & Existing Facilities & Waste Management Practices & Initiatives \\
\hline \multirow[t]{9}{*}{ United States } & $\begin{array}{l}\text { Barnwell: located in South Carolina; } \\
\text { commercial LLW disposal facility; accepts } \\
\text { Class A, B, and C waste from only from Atlantic } \\
\text { Compact States. }\end{array}$ & $\begin{array}{l}\text { Shallow land disposal in concrete vaults } \\
\text { and in engineered earthen trenches. }\end{array}$ & \multirow{3}{*}{$\begin{array}{l}\text { A fourth commercial and federal LLW facility is } \\
\text { currently under construction in Andrews County, } \\
\text { Texas. Licensed in } 2009 \text { for Class A, B, and C } \\
\text { waste, this facility will accept waste from Federal } \\
\text { facilities and Texas Compact States. The disposal } \\
\text { cells will be constructed in low-permeability clay } \\
\text { formation below at least } 9 \mathrm{~m} \text { from the top. }\end{array}$} \\
\hline & $\begin{array}{l}\text { Clive: located in Utah; commercial LLW } \\
\text { disposal facilities; accepts only Class A waste } \\
\text { from waste from Federal facilities and all } \\
\text { regions of the US. }\end{array}$ & $\begin{array}{l}\text { Above grade engineered disposal cells (or } \\
\text { landfill embankments). }\end{array}$ & \\
\hline & $\begin{array}{l}\text { Richland: located in Washington State; } \\
\text { commercial LLW disposal facilities; accepts } \\
\text { Class A, B, and C waste from Northwest and } \\
\text { Rocky Mountain Compact States. }\end{array}$ & $\begin{array}{l}\text { Conventional shallow-land burial in the } \\
\text { trenches. }\end{array}$ & \\
\hline & $\begin{array}{l}\text { Hanford: DOE LLW site; located in Washington } \\
\text { State; accepts waste from Hanford site only. }\end{array}$ & $\begin{array}{l}\text { Shallow landfill disposal using standard } \\
\text { trench design and engineered cells. }\end{array}$ & \\
\hline & $\begin{array}{l}\text { Idaho National Laboratory (INL): DOE LLW site; } \\
\text { accepts waste from INL only. }\end{array}$ & $\begin{array}{l}\text { Disposal via burial in pits, trenches, soil } \\
\text { vault rows, and concrete vaults. Also has } \\
\text { an engineered facility with modular design } \\
\text { disposal cells. }\end{array}$ & \\
\hline & $\begin{array}{l}\text { Los Alamos National Laboratory (LANL): DOE } \\
\text { LLW site; accepts on-site LLW for disposal, } \\
\text { although in special cases off-site waste has } \\
\text { been accepted from Defense Programs sites. }\end{array}$ & $\begin{array}{l}\text { Disposal area consists of landfill cells (pits } \\
\text { and trenches) and land disposal shafts. }\end{array}$ & \\
\hline & $\begin{array}{l}\text { Nevada Test site (NTS): DOE LLW site; } \\
\text { accepts LLW materials that were generated in } \\
\text { the Nation's Defense Programs (DP) activities. }\end{array}$ & $\begin{array}{l}\text { Disposal facilities consist of either of } \\
\text { shallow excavated disposal trenches or in } \\
\text { surface subsidence craters (that were } \\
\text { formed in the early 1960s by underground } \\
\text { nuclear tests). }\end{array}$ & \\
\hline & $\begin{array}{l}\text { Oak Ridge Site (ORR): DOE LLW site; accepts } \\
\text { waste from ORR only. }\end{array}$ & $\begin{array}{l}\text { Disposal activities have primarily included } \\
\text { engineered surface, deep well injection, } \\
\text { and trenches). }\end{array}$ & \\
\hline & $\begin{array}{l}\text { Savannah River Site (SRS): DOE LLW site; } \\
\text { accepts waste from different DOE sites. }\end{array}$ & $\begin{array}{l}\text { Burial in vaults and trenches. Past disposal } \\
\text { in engineered trenches. }\end{array}$ & \\
\hline
\end{tabular}




\section{REFERENCES}

ANDRA (Agence nationale pour la gestion des déchets radioactifs, or French National Radioactive Waste Management Agency). 2006. Disposal Facilities: Preserving a Collective Memory... for Future Generations. Essential Series 299VA. (September). Available at http://www.andra.fr/download/andra-international-en/document/editions/299.pdf.

ANDRA. 2008. A new disposal facility for very-low-level radioactive waste. Essential Series 232VA. (July). Available at http://www.andra.fr/download/andra-internationalen/document/editions/232.pdf.

ANDRA. 2009. Rapport annuel 2008: Centre de stockage de la Manche. (June). Available at http://www.andra.fr/download/site-principal/document/editions/329.pdf.

ANDRA. 2010. Visitez les sites de l'Andra pour comprendre la gestion des déchets radioactifs. Brochure 206/C. (January). Available at http://www.andra.fr/download/siteprincipal/document/editions/206c.pdf.

ANDRA, 2011a, Le Centre de stockage. Andra in Manche website. (July 1). Available at http://www.andra.fr/andra-manche/pages/fr/menu7//-andra-dans-la-manche/le-centre-destockage-1061.html.

ANDRA. 2011b. Les Centres de stockage FMA et TFA. Andra in Aube website. (August 1). Available at http://www.andra.fr/andra-aube/pages/fr/menu4/l-andra-dans-l-aube/les-centres-destockage-tfa-et-fma-1081.html.

ARN (Autoridad Regulatoria Nuclear, or Argentinean Nuclear Regulatory Authority). 2010. Argentinean National Report for The Convention on Nuclear Safety, Fifth Report. (August) http://www.arn.gob.ar/images/stories/informes y documentos/informe nacional de seguridad/ NATIONAL NUCLEAR SAFETY REPORT 2010.pdf

ARPANSA (Australian Radiation Protection and Nuclear Safety Agency). 2010. Safety Guide: Classification of Radioactive Waste. Radiation Protection Series No. 20. Australian Government. (April). Available at www.arpansa.gov.au/pubs/rps/rps20.pdf

ASN (Autorité de Sûreté Nucléaire, or French Nuclear Safety Authority). 2009. National plan on management of radioactive materials and waste (PNGMDR). (October 6) Available at http://www.asn.fr/index.php/English-version/References/National-plan-on-management-ofradioactive-materials-and-waste-PNGMDR.

Audero, M. 2004. Radioactive Waste Management in Argentina. in Proceedings of the IAEA International Conference on Issues and Trends in Radioactive Waste Management. IAEA-CN90. Vienna, Austria. (December 9-13). Available at http://www.iaea.org/inis/collection/NCLCollectionStore/ Public/34/016/34016274.pdf. 
Baltzer, R. 2010. Comments to Proposed Chapter 675, Subchapter B "Exportation and Importation of Waste". letter from R. Baltzer (President, Waste Control Specialists, LLC, Dallas, TX), to M. Ford (Chairman, Texas Low-Level Radioactive Waste Disposal Commission, Austin, TX) with cc to M. Henderson (Executive Director, Waste Control Specialists, LLC), B. Lindquist, and B. Kroger. (April 13).

Belgium, Kingdom of. 2006. National Report for the Second meeting of the Contracting Parties to the Joint Convention on the Safety of Spent Fuel Management and on the Safety of Radioactive Waste Management. Federal Agency for Nuclear Control. (May). Available at http://www.fanc.fgov.be/download/JointConv 121005noannex.pdf.

Belgoprocess. 2009. About Us. Company website. Available at http://www.belgoprocess.be/eng/AboutUs.htm.

Bergman, C. 2006. Model repository for low and intermediate level short lived waste, presented at CEG workshop on "Isolation and Disposal of Radioactive Waste." Olkiluoto, Finland. (June 28-30). Available at http://www.iaea.org/OurWork/ST/NE/NEFW/CEG/documents/ws062006 13E.pdf.

BfS (Bundesamtes für Strahlenschutz, or German Federal Office for Radiation Protection). 2003. Our Guiding Principles: Federal Office for Radiation Protection Responsibility for Man and Environment. Agency website. (April 14). Available at http://www.bfs.de/en/bfs/wir/leitbild.html.

BMU (Bundesministerium für Umwelt, or German Federal Ministry for the Environment, Nature Conservation, and Nuclear Safety). 2008. Joint Convention for the Safety of Spent Fuel Management and on the Safety of Radioactive Waste Management, Report of the Federal Republic of Germany for the Third Review Meeting. Federal Republic of Germany. (October). Available at http://www.bmu.de/files/pdfs/allgemein/application/pdf/3nationaler bericht atomenergie en.pdf

BMWi (Bundesministerium für Wirtschaft und Technologie, or German Federal Ministry of Economics and Technology). 2006. German-Russian nuclear submarine decommissioning project: Long term storage facility (LTST) and radioactive waste storage facility (RWSF) at Sayda Bay. Berlin. (July 18). Available at http://www.bmwi.de/English/Redaktion/Pdf/publikationu-boote-2006-en, property=pdf,bereich=bmwi,sprache=en, rwb=true.pdf.

BMWi. 2011. German Ministry of Economics and Technology project for the dismantlement of nuclear powered submarines. Agency website. Berlin. Available at http://www.bmwi.de/English/Navigation/external-economic-policy,did=307412.html.

Booth, P.M. 2007, "Socioeconomic issues and public involvement practices and approaches for developing and operating repositories for low and intermediate level waste UK perspective," In Low and Intermediate Level Waste Repositories: Socioeconomic Aspects and Public Involvement, Proceedings of a workshop. International Atomic Energy Agency (IAEA). Waste Technology Section. Vienna, Austria. IAEA-TECDOC-1553. (June). Available at http://wwwpub.iaea.org/MTCD/publications/PDF/te 1553 web.pdf. 
Borissova, K. 2007. "Public information \& ensuring transparency in the decision making process of SE RAW," In Low and Intermediate Level Waste Repositories: Socioeconomic Aspects and Public Involvement, Proceedings of a workshop. International Atomic Energy Agency (IAEA). Waste Technology Section. Vienna, Austria. IAEA-TECDOC-1553. (June). Available at http://www-pub.iaea.org/MTCD/publications/PDF/te 1553 web.pdf.

Borrmann, F., P. Brennecke, W. Koch, K. Kugel, and S. Steyer. 2007. "Germany: Management of Decommissioning Waste in Germany," In Disposal Aspects of Low and Intermediate Level Decommissioning Waste: Results of a coordinated research project 2002-2006. CD-ROM. IAEA-TECDOC-1572. (December). Available at http://www-pub.iaea.org/MTCD/publications/PDF/TE 1572 companion CD web.pdf.

Bouldin, B. 2004. Russian Government Restructuring and the Future of WMD Threat Reduction Cooperation: A Preliminary Analysis. RANSAC Policy Update. (March). Available at http://www.ransac.org/documents/rfgovtrestructuring032604.pdf.

Bradley D.J. 1997. Behind the Nuclear Curtain: Radioactive Waste Management in the Former Soviet Union. Battelle Press. Columbus, Ohio.

Brewitz, W. and T. Rothfuchs. 2007. Concepts and Technologies for Radioactive Waste Disposal in Rock Salt. Acta Montanistica Slovaca, 12:67-74. Available at http://actamont.tuke.sk/pdf/2007/s1/10brewitz.pdf.

BSRRW (Baltic Sea Region Radioactivity Watch). 2009. The Low Level Waste Repository already operating at Forsmark. Organization website. Available at http://www.bsrrw.org/?page id=111.

Bulgaria, Republic of. 2010. Strategy for Managing the Spent Nuclear Fuel and Radioactive Waste until 2030. Draft report by the Council of Ministers. Available at http://www.strategy.bg/StrategicDocuments/View.aspx?lang=en-GB\&ld=681.

Carlsson, J. 2007. "Sweden: Performance Assessment of a Planned Near-Surface Repository for Short Lived Waste from Decommissioning of Swedish Nuclear Power Plants," In Disposal Aspects of Low and Intermediate Level Decommissioning Waste: Results of a coordinated research project 2002-2006. CD-ROM. IAEA-TECDOC-1572. (December). Available at http://www-pub.iaea.org/MTCD/publications/PDF/TE 1572 companion CD web.pdf.

China, The People's Republic of. 2008. Joint Convention on the Safety of Spent Fuel Management and on the Safety of Radioactive Waste Management, National Report. Beijing, China. (September). Available at http://www.vatesi.lt/fileadmin/documents/Ataskaitos/Kinijos.pdf.

CNSC (Canadian Nuclear Safety Commission). 2008. Canadian National Report for the Joint Convention for the Safety of Spent Fuel Management and on the Safety of Radioactive Waste Management - Third Report. Minister of Public Works and Government Services. Government of Canada. (October). Available at http://www.nuclearsafety.gc.ca/pubs catalogue/uploads/joint convention 2009 third national $r$ eport e.pdf. 
CoA (Commonwealth of Australia). 2008. Joint Convention on the Safety of Spent Fuel Management and on the Safety of Radioactive Waste Management National Report. Prepared for the Third Review Meeting in frames of the Joint Convention on the Safety of Spent Fuel Management and the Safety of Radioactive Waste Management. (October). Available at http://www.arpansa.gov.au/pubs/regulatory/conventions/jc09 aust thirdreview.pdf.

Cochran, T.B., R.S. Norris, and O. A. Bukharin. 1995. Making the Russian Bomb: From Stalin to Yeltsin, Natural Resources Defense Council. Westview Press. Boulder, Colorado. Available at http://docs.nrdc.org/nuclear/nuc 01019501a 138.pdf.

Compton, K.L., V.Novikov, and F.L. Parker. 2000. Deep Well Injection of Liquid Radioactive Waste at Krasnoyarsk-26: Volume I. RR-00-1. International Institute for Applied Systems Analysis. Laxenburg, Austria. (February). Available at http://www.iiasa.ac.at/Admin/PUB/Documents/RR-00-001.pdf.

CORAR (Council on Radionuclides and Radiopharmaceuticals). 2010. Executive Summary: Biomedical Research Products Deleted Due to Radioactive Waste Issues. (January 7). (Available from ADAMS - Accession Number ML100060060).

Cosemans, C. 2004. The Inventory of Radioactive Waste as an Integrated Part of a Low-Level Radioactive Waste Management System. (November 19). Available at http://newmdb.iaea.org/Library.aspx?Sort1=1\&PageSize=20\&ListDetail=1\&Pagelndex=1\&IsoCo $\underline{\mathrm{de}}=\mathrm{BE}$

Crawford, M. 2010. Dounreay New Low Level Waste Facilities: RSA 93 Environmental Safety Case 2010. Scottish Environment Protection Agency (SEPA). NLLWF/3/ESC/GAL/0425/IS/01. (October 27). Available at http://www.dounreay.com/UserFiles/File/New\%20Low\%20Level\%20Waste\%20Disposal\%20Fac ilities/Environmental\%20Safety\%20Case\%202010.pdf.

DBE (Deutsche Gesellschaft zum Bau und Betrieb von Endlagern für Abfallstoffe mbH, or German Company for the Construction and Operation of Waste Repositories). 2011. Company website. Available at http://www.dbe.de/en/about-dbe/activities-of-dbe/index.php.

DECC (UK's Department of Energy and Climate Change). 2008. The United Kingdom's Third National Report on Compliance with the Obligations of the Joint Convention for the Safety of Spent Fuel Management and on the Safety of Radioactive Waste Management. Health and Safety Executive. (May 30). Available at http://www.decc.gov.uk/assets/decc/what\%20we\%20do/uk\%20energy\%20supply/energy\%20mi x/nuclear/radioactivity/iaeajointconvention/120091118140636 e @@ thirdukjointconventionre port.pdf.

DECC. 2010. The United Kingdom's Fifth National Report on Compliance with the Convention on Nuclear Safety Obligations. Health and Safety Executive. (October). Available at http://www.decc.gov.uk/assets/decc/What\%20we\%20do/UK\%20energy\%20supply/Energy\%20 mix/Nuclear/issues/safety/international/731-uk-5th-nuclear-safety-obs.pdf.

Derveaux, K., and A. Waffeleart. 2004. Belgian Low-Level and Short-Lived Waste: Does It Belong in Dessel?. STOLA. Dessel, Belgium. (November). Available at http://www.stora.org/assets/stola/publicaties/bergingsproject\%20eng.pdf. 
Dmitriev S.A. 2007. "Long term storage of institutional radioactive waste: Ecological and social issues," In Low and Intermediate Level Waste Repositories: Socioeconomic Aspects and Public Involvement, Proceedings of a workshop. International Atomic Energy Agency (IAEA). Waste Technology Section. Vienna, Austria. IAEA-TECDOC-1553. (June). Available at http://wwwpub.iaea.org/MTCD/publications/PDF/te 1553 web.pdf.

DOE (U.S. Department of Energy). 2000. The Current and Planned Low-Level Waste Disposal Capacity Report, Revision 2. Office of Environmental Management. (December). Available at http://www.em.doe.gov/pdfs/llwrev2.pdf.

DOE. 2007. Radioactive Waste Management Manual. DOE M 435.1-1. (January). Available at https://www.directives.doe.gov/directives/current-directives/435.1-DManual-1c1/view.

DOE. 2008. United States of America Third National Report for the Joint Convention on the Safety of Spent Fuel Management and on the Safety of Radioactive Waste Management. DOE/EM-0654, Rev. 2. Washington, DC. (October). Available at http://www.em.doe.gov/pdfs/3rd\%20US\%20Rpt\%20on\%20SNF\%20JC-\%20COMPLETE\%20REPORT\%20-\%2010\%2013\%2008.pdf.

United States Department of Energy

DOE. 2010. Hanford Site. Agency website. Available at http://www.hanford.gov.

DRET (Australian Department of Resources, Energy and Tourism). 2009. Proposed Commonwealth Radioactive Waste Management Facility, Northern Territory: Synthesis Report. Australian Government. (March 13). Available at http://www.ret.gov.au/resources/Documents/radioactive waste/radioactive\%20waste\%20manag ement/08-0589-01-2145479A\%20(Synthesis).pdf.

DRET. 2011a. Amounts of Radioactive Waste in Australia. Australian Government. (August 12). Available at http://www.ret.gov.au/resources/radioactive waste/radiation radioactive/Pages/AmountsofRadi oactiveWasteinAustralia.aspx

DRET. 2011b. Radioactive Waste Management in Australia. Australian Government. (January 31). Available at http://www.ret.gov.au/resources/radioactive waste/waste mgt in aust/Pages/RadioactiveWast eManagementinAustralia.aspx.

DSRL (Dounreay Site Restoration Limited). 2011. New Low Level Waste Facilities. Company website. Available at http://www.dounreay.com/waste/radioactive-waste/low-level-waste/newlow-level-waste-facilities.

DTF (Australian Department of Treasury and Finance). 2011. Mt Walton East Intractable Waste Disposal Facility. Building Management and Works division, Government of Western Australia. Available at http://www.finance.wa.gov.au/cms/content.aspx?id=3903.

Dutch, S. 1999. The Russian Radioactive Waste Injection Program: Graphics based on illustrations in The New York Times. Natural and Applied Sciences, University of Wisconsin Green Bay. (September 25). Available at http://www.uwgb.edu/dutchs/EarthSC202Notes/Grndh2o.htm. 
EC (European Commission). 2010. Proposal for a Council Directive on the management of spent fuel and radioactive waste. $\operatorname{COM(2010)} 618$ final. 2010/0306 (NLE). Brussels, Belgium. (March 11). Available at http://www.environ.ie/en/Legislation/Environment/EnvironmentalRadiation/FileDownLoad,24976. en.pdf.

EcoLur. 2011. Radioactive Waste Burial Site Project Not Closed. Organization website. (January 10). Available at http://www.ecolur.org/en/news/waste/radioactive-waste-burial-siteproject-not-closed/1895/.

EIA (U.S. Energy Information Administration). 2005. Salt Lake City Mill Site (Preliminary), Salt Lake County, Utah. Agency website. (October 9). http://www.eia.doe.gov/cneaf/nuclear/page/umtra/salt lake title1.html.

ENS (European Nuclear Society). 2006, Post-Conference Technical Visit. 10th International Topical Meeting on Research Reactor Fuel Management (RRFM). (May). Available at http://www.euronuclear.org/meetings/rrfm2006/technical.htm.

EPA (Australian Environmental Protection Authority). 2000. Intractable Waste Disposal Facility, Mt Walton East, Change to Environmental Conditions Waste Management (WA). Section 46 Report and Recommendations. Bulletin 1005. Perth, Western Australia. (December). Available at http://epa.wa.gov.au/EPADocLib/967 B1005.pdf.

Fahey, C. 2010. Port Hope Project Update: Port Hope Area Initiative. Presentation to Council Municipality of Port Hope. (April 20). Available at http://www.porthope.ca/en/resources/PHAIProjectUpdateApril202010.pdf.

FAO (Food and Agriculture Organization of the United Nations). 2005. Mapping global urban and rural population distributions. Rome, Italy. Available at http://www.fao.org/docrep/009/a0310e/a0310e00.htm.

FEPC (Federation of Electric Power Companies of Japan). 2002. Japan's Nuclear Power Program. Available at http://www.japannuclear.com/nuclearpower/nuclearpower.html.

Fleming, P.M., and R.P. Mourão, 2007, "The present status of public acceptance of radioactive waste repositories in Brazil," In Low and Intermediate Level Waste Repositories: Socioeconomic Aspects and Public Involvement, Proceedings of a workshop. International Atomic Energy Agency (IAEA). Waste Technology Section. Vienna, Austria. IAEA-TECDOC-1553. (June). Available at $\underline{\text { http://www-pub.iaea.org/MTCD/publications/PDF/te } 1553 \text { web.pdf. }}$

FNCA (Forum for Nuclear Cooperation in Asia). 2007. Updated RWM Consolidated Report, on Radioactive Waste Management in FNCA Countries. FNCA RWM-R004. Radioactive Waste Management Project Group, Forum for Nuclear Cooperation in Asia. (March). Available at http://www.fnca.mext.go.jp/english/rwm/e consolidated.html\#r004.

FRB (Federal Republic of Brazil). 2008. National Report of Brazil 2008, For the Third Review Meeting of the Joint Convention on the Safety of Spent Fuel Management and on the Safety of Radioactive Waste Management. (October). Available at http://www.cnen.gov.br/seguranca/documentos/Waste final 08.pdf 
FRB. 2010. Fifth National Report of Brazil for the Nuclear Safety Convention. (September). Available at http://www.cnen.gov.br/seguranca/documentos/5NationalReportDraft5l.pdf.

GlobalSecurity.org. 2005a. Krasnoyarsk-26/Zheleznogorsk, Mining and Chemical Combine [MCA], within Weapons of Mass Destruction (WMD). (April 28). Available at http://www.globalsecurity.org/wmd/world/russia/krasnoyarsk-26 nuc.htm.

GlobalSecurity.org. 2005b. Tomsk-7/Seversk, Combine 816/Siberian Chemical Combine, within Weapons of Mass Destruction (WMD). (April 28). Available at http://www.globalsecurity.org/wmd/world/russia/tomsk-7 nuc.htm.

Grattone, N. 2010. Argentina Waste Context. National Atomic Energy Commission. National Radioactive Waste Management (PNGRR). (June). Available at http://www.sandia.gov/IAEA/Student Presentations/Natalia Grattone Argentina.pdf.

Harriague, S., C. Barberis, E. Cinat, C. Grizutti, and H. Scolari. 2007. "Argentina: Disposal Aspects of Ra-1 Research Reactor Decommissioning Waste," In Disposal Aspects of Low and Intermediate Level Decommissioning Waste: Results of a coordinated research project 20022006. CD-ROM. IAEA-TECDOC-1572. (Dec.). Available at http://www-pub.iaea.org/MTCD/publications/PDF/TE 1572 companion CD web.pdf.

Hartley, B.M. 1998. The Establishment of a Radioactive Waste Disposal Facility in Western Australia for Low Level Waste. Applied Radiation and Isotopes. 49(3): 259-264.

Hooft, E., and J-P. Boyazis. 2007. "Local partnership for developing an integrated project for the disposal of low level short lived waste - The Belgian experience," In Low and Intermediate Level Waste Repositories: Socioeconomic Aspects and Public Involvement, Proceedings of a workshop. International Atomic Energy Agency (IAEA), Waste Technology Section. Vienna, Austria. IAEA-TECDOC-1552. (December). Available at http://wwwpub.iaea.org/MTCD/publications/PDF/te 1553 web.pdf.

HSS (U.S. Office of Health, Safety and Security). 2011. U.S. Department of Energy. Agency website. Available at http://www.hss.doe.gov/index.html.

IAEA (International Atomic Energy Agency). 2001a. Procedures and Techniques for Closure of Near Surface Disposal Facilities for Radioactive Waste. IAEA-TECDOC-1260. Vienna, Austria. (December). Available at http://www.iaea.org/inis/collection/NCLCollectionStore/ Public/33/003/33003360.pdf.

IAEA. 2001b. Technical Considerations in the Design of Near Surface Disposal Facilities for Radioactive Waste. IAEA-TECDOC-1256. Vienna, Austria. (November). Available at http://www.iaea.org/inis/collection/NCLCollectionStore/ Public/33/003/33003335.pdf.

IAEA. 2003a. "Canada," In Country Nuclear Power Profiles, 2009 Edition. (December). Available at http://wwwpub.iaea.org/MTCD/publications/PDF/cnpp2009/countryprofiles/Canada/Canada2003.htm.

IAEA. 2003b. "People's Republic of China," In Country Nuclear Power Profiles, 2009 Edition. (December). Available at http://wwwpub.iaea.org/MTCD/publications/PDF/cnpp2009/countryprofiles/China/China2003.htm. 
IAEA. 2004. "Argentina," In Country Nuclear Power Profiles, 2009 Edition. (December). Available at http://wwwpub.iaea.org/MTCD/publications/PDF/cnpp2009/countryprofiles/Argentina/Argentina2004.htm

IAEA. 2006a. "Armenia," In Country Nuclear Power Profiles, 2009 Edition. (December). Available at http://wwwpub.iaea.org/MTCD/publications/PDF/cnpp2009/countryprofiles/Armenia/Armenia2006.htm.

IAEA. 2006b. "Brazil," In Country Nuclear Power Profiles, 2009 Edition. (December). Available at http://wwwpub.iaea.org/MTCD/publications/PDF/cnpp2009/countryprofiles/Brazil/Brazil2006.htm

IAEA. 2006c. "France," In Country Nuclear Power Profiles, 2009 Edition. (December). Available at http://www-

pub.iaea.org/MTCD/publications/PDF/cnpp2009/countryprofiles/France/France2006.htm.

IAEA. 2006d. Improvements of radioactive waste management at WWER nuclear power plants. IAEA-TECDOC-1492. Vienna, Austria. (April). Available at http://wwwpub.iaea.org/MTCD/publications/PDF/te 1492 web.pdf.

IAEA. 2006e. "United Kingdom," In Country Nuclear Power Profiles, 2009 Edition. (August). Available at http://www-

pub.iaea.org/MTCD/publications/PDF/cnpp2009/countryprofiles/UnitedKingdom/UnitedKingdom 2006.htm.

IAEA. 2007. Disposal Aspects of Low and Intermediate Level Decommissioning Waste: Results of a coordinated research project 2002-2006. IAEA-TECDOC-1572. Vienna, Austria.

(December). Available at http://www-pub.iaea.org/MTCD/publications/PDF/te 1572 web.pdf

IAEA. 2009a. "Bulgaria," In Country Nuclear Power Profiles, 2009 Edition. (July). Available at http://www-

pub.iaea.org/MTCD/publications/PDF/cnpp2009/countryprofiles/Bulgaria/Bulgaria2004.htm.

IAEA. 2009b. Classification of Radioactive Waste: General Safety Guide. IAEA Safety Standards Series No. GSG-1. Vienna, Austria. Available at http://www-pub.iaea.org/MTCD/publications/PDF/Pub1419 web.pdf

IAEA. 2009c. "Germany," In Country Nuclear Power Profiles, 2009 Edition. (March). Available at http://www-

pub.iaea.org/MTCD/publications/PDF/cnpp2009/countryprofiles/Germany/Germany2008.html.

IAEA. 2009d. "Republic of Korea," In Country Nuclear Power Profiles, 2009 Edition. (March). Available at http://www-

pub.iaea.org/MTCD/publications/PDF/cnpp2009/countryprofiles/Korea/Korea2008.html.

IAEA. 2009e. "Sweden," In Country Nuclear Power Profiles, 2009 Edition. (August). Available at http://wwwpub.iaea.org/MTCD/publications/PDF/cnpp2009/countryprofiles/Sweden/Sweden2006.htm. 
IAEA. 2009f. "Ukraine," In Country Nuclear Power Profiles, 2009 Edition. (August). Available at http://www-

pub.iaea.org/MTCD/publications/PDF/cnpp2009/countryprofiles/Ukraine/Ukraine2003.htm.

IAEA. 2010. International Status and Prospects of Nuclear Power. Report by the Director General, Board of Governors General Conference. GOV/INF/2010/12-GC(54)/INF/5. (September 2). Available at www.iaea.org/About/Policy/GC/GC54/GC54InfDocuments/English/gc54inf-5 en.pdf

IAEA. 2011a. Country Waste Profiles. The Net-Enabled Waste Management Database (NEWMDB). Available at http://newmdb.iaea.org/profiles.aspx.

IAEA. 2011b. Power Reactor Information Center (PRIS). Available at http://www.iaea.org/programmes/a2/index.html.

India, Government of. 2007. National Report of the Republic of India, for The Convention on Nuclear Safety, Fourth Review Meeting of Contracting Parties. (September). Available at http://www.aerb.gov.in/t/news/IndianNationalReportCNS.pdf.

India, Government of. 2010. National Report of the Republic of India, for the Convention on Nuclear Safety, Fifth Review Meeting of Contracting Parties. (August). Available at http://www.aerb.gov.in/t/news/CNS2010.pdf.

IOO (Idaho Operations Office). 2006. ICDF Complex Remedial Action Report, Revision 0. Department of Energy. DOE/ID-11252. (September). Available at http://ar.inel.gov/images/pdf/200609/2006092800989TUA.pdf.

Japan, Government of. 2008. Joint Convention for the Safety of Spent Fuel Management and on the Safety of Radioactive Waste Management, National Report of Japan for the Third Review Meeting. (October). Available at http://www.meti.go.jp/english/report/data/Japan mainpages.pdf.

Jinchuk, D. 1999. "An Option for the Management if Radioactive Waste in Argentina," In Proceedings of the International Symposium on Technologies for the Management of Radioactive Waste from Nuclear Power Plants and Back End Nuclear Fuel Cycle Activities. IAEA-SM-357. Taejon, Republic of Korea. (August 30 - September 3). Available at http://wwwpub.iaea.org/MTCD/publications/PDF/csp 006c/PDF-Files/paper-77p.pdf.

JNFL (Japan Nuclear Fuel Limited). 2011. Low Level Radioactive Waste Disposal Center. Company website. Available at http://www.jnfl.co.jp/english/.

Johnson, A.R. 2009. New Russian law on radioactive waste management. Decommission: Dismantling of Old Nuclear Power Plants website, cooperation project between NGOs (nongovernmental organizations) Zelenyj Mir/Green World, Gaia Apatity Ecological Center, Za Prirodu, and Norges Naturvernforbund/Friends of the Earth Norway. (June 16). Available at http://www.decomatom.org/node/72. 
Kim, C-L., J.B. Park, and J.W. Park. 2007. "Republic of Korea, a Study on the Disposal Concept and Packaging of Low- and Intermediate-Level Decommissioning Waste in Korea." In Disposal Aspects of Low and Intermediate Level Decommissioning Waste: Results of a coordinated research project 2002-2006. CD-ROM. IAEA-TECDOC-1572. (December). Available at http://www-pub.iaea.org/MTCD/publications/PDF/TE 1572 companion CD web.pdf.

Kim ,H. 2010. Challenges of New National Organization for Radioactive Waste Management in Korea. presented at IAEA Technical Meeting. Paris, France. (June 7-9). Available at http://wwwns.iaea.org/downloads/rw/conventions/fourth-review-cycle/tm-paris/Session\%202/korea-kim.pdf.

Korea, Republic of. 2008. Korea Third National Report under the Joint Convention for the Safety of Spent Fuel Management and on the Safety of Radioactive Waste Management. Ministry of Education, Science \& Technology. (October). Available at http://www.kins.re.kr/pdf/Korean\%20Third\%20National\%20Report\%202008.pdf

Kozulko, T. 2007. "Public involvement for developing and operating repositories for low and intermediate level radioactive waste - Approaches in Ukraine," In Low and Intermediate Level Waste Repositories: Socioeconomic Aspects and Public Involvement, Proceedings of a workshop. International Atomic Energy Agency (IAEA). Waste Technology Section. Vienna, Austria. IAEA-TECDOC-1553. (June). Available at http://wwwpub.iaea.org/MTCD/publications/PDF/te 1553 web.pdf.

Kristof, E. 2010. Nuclear-Waste Pileup and Tumbling Waste. National Geographic photographs. (July 8). Available at http://news.nationalgeographic.com/news/2010/07/photogalleries/100708radioactive-nuclear-waste-science-salt-mine-dump-pictures-asse-ii-germany/\#/salt-minenuclear-waste-asse-germany-loader-barrels 23154 600x450.jpg.

Kumar, S., S.S. Ali, M. Chander, N.K. Bansal, and K. Balu. 1999. "Integrated Radioactive Waste Management from NPP, Research Reactor, and Back End of Nuclear Fuel Cycle - An Indian Experience," In Proceedings of the International Symposium on Technologies for the Management of Radioactive Waste from Nuclear Power Plants and Back End Nuclear Fuel Cycle Activities. IAEA-SM-357. Taejon, Republic of Korea. (August 30 - September 3). Available at http://www-pub.iaea.org/MTCD/publications/PDF/csp 006c/PDF-Files/paper-38.pdf.

Lempert, J.P., and E. Biurrun. 1999. "Deep Geological Radioactive Waste Disposal in Germany: Lessons Learned and Future Perspectives," In Proceedings of the International Symposium on Technologies for the Management of Radioactive Waste from Nuclear Power Plants and Back End Nuclear Fuel Cycle Activities. IAEA-SM-357. Taejon, Republic of Korea. (August 30 September 3). Available at http://www-pub.iaea.org/MTCD/publications/PDF/csp 006c/PDFFiles/paper-16p.pdf.

Lindberg, C. 2006. Swedish Experience from Siting, Construction and Operation of RW Disposal Facilities, presented at CEG workshop on "Isolation and Disposal of Radioactive Waste." Olkiluoto, Finland. (June 28-30). Available at http://www.iaea.org/OurWork/ST/NE/NEFW/CEG/documents/ws062006 10E.pdf. 
Linge, I.I. 2009. Draft State Federal Legislation: Treatment of Radioactive Waste. presented at the Contact Expert Group (CEG) Workshop on Management of Spent Nuclear Fuel and Radioactive Waste: Regulatory and Licensing Issues. St. Petersburg, Russia. (May 27-28). Available at http://www.iaea.org/OurWork/ST/NE/NEFW/CEG/documents/ws052009/1.3\%20Linge\%20Eng.p df.

LLW Repository Ltd., 2011. Planning Application. Available at http://www.llwrsite.com/llwstrategy/planning-application.

Maset, E. and R. Andresik. 2007. "Present situation of the low level waste repository in Argentina and the necessity for developing a new site," In Low and Intermediate Level Waste Repositories: Socioeconomic Aspects and Public Involvement, Proceedings of a workshop. International Atomic Energy Agency (IAEA). Waste Technology Section. Vienna, Austria. IAEATECDOC-1553. (June). Available at http://wwwpub.iaea.org/MTCD/publications/PDF/te 1553 web.pdf.

Metcalfe, D., P.W. Yuen, D. McCauley, S. Brooks, J. Miller, and M. Stephens. 2009. "Implementation and Ongoing Development of a Comprehensive Program to Deal with Canada's Nuclear Legacy Liabilities". In Proceedings of the 12th International Conference on Environmental Remediation and Radioactive Waste Management. ICEM2009-16039. Liverpool, UK. (Oct. 11-15). Available at http://www.nuclearlegacyprogram.ca/en/documents/ICEM2009 16039.pdf.

MPH (Municipality of Port Hope). 2009. Port Hope Area Initiative (PHAI). Municipality website. Available at http://www.porthope.ca/en/residentservices/PHAl.asp.

Munshi, S.K. 2007. "Socioeconomic issues and public involvement practices for near surface disposal of low and intermediate level radioactive waste - Indian approach," In Low and Intermediate Level Waste Repositories: Socioeconomic Aspects and Public Involvement, Proceedings of a workshop. International Atomic Energy Agency (IAEA). Waste Technology Section. Vienna, Austria. IAEA-TECDOC-1553. (June). Available at http://wwwpub.iaea.org/MTCD/publications/PDF/te 1553 web.pdf.

NHMRC (Australian National Health and Medical Research Council). 1992. Code of practice for the near-surface disposal of radioactive waste in Australia. Radiation Health Series No. 35. Australian Government Publishing Service. Canberra, Australia. (November). Available at http://www.arpansa.gov.au/pubs/rhs/rhs35.pdf.

Nikitin, A. 2010. The new bill on radioactive waste management in Russia: An analysis. Position paper. The Bellona Foundation website. (January 7). Available at http://www.bellona.org/position papers/new bill on radwaste.

NIRS (Nuclear Information and Resource Service). 2009a. United States Commercial "LowLevel" Radioactive Waste Disposal Sites Fact Sheet. (April). Available at http://www.nirs.org/factsheets/wastesitesfctst43009.pdf.

NIRS. 2009b. United States Commercial "Low-Level" Radioactive Waste Disposal Sites Fact Sheet: Nuclear Information and Resource Service. (April). Available at http://nukefreetexas.org/downloads/NIRS low level radioactive waste factsheet.pdf. 
NLLP (Canadian Nuclear Legacy Liabilities Program). 2010. Phases of the Nuclear Legacy Liabilities Program. Natural Resource Canada. Agency website. Available at http://www.nuclearlegacyprogram.ca/en/phases en.html.

NNSA (Chinese National Nuclear Safety Administration). 2009. Annual Report for Nuclear Safety. Ministry of Environmental Protection, The People's Republic of China. Available at http://english.mep.gov.cn/standards reports/nuclearsafetyAR/AR2009/201101/P020110105325 549842424.pdf.

NRC (U.S. Nuclear Regulatory Commission). 1982. Part 61--Licensing Requirements for Land Disposal of Radioactive Waste. NRC Regulations Title 10, Code of Federal Regulations. 47 FR 57463. (December 27). Available at http://www.nrc.gov/reading-rm/doccollections/cfr/part061/full-text.html.

NRC. 2008a. Considerations for Extended Interim Storage of Low-Level Radioactive Waste by Fuel Cycle and Material Licensees. Regulatory Issue Summary 2008-32. (May 9). (Available from the ADAMS- ML073330725).

NRC. 2008b. Interim Storage of Low-Level Radioactive Waste at Reactor Sites. Regulatory Issue Summary 2008-12. (December 30). (Available from the ADAMS- ML082190768).

NRC. 2009a. Annual Review of the Need for Rulemaking and/or Regulatory Guidance on LowLevel Radioactive Waste Storage. Policy Issue Information. SECY-09-0188. (December 31).

NRC. 2009b. Fact Sheet - Depleted Uranium and Other Waste Disposal. (August). Available at http://www.nrc.gov/reading-rm/doc-collections/fact-sheets/fs-du-other-waste-disposal.pdf.

NRC. 2010. Blending of Low-Level Radioactive Waste. Policy Issue (Notation Vote). SECY-100043. (April 7). Available at http://www.nrc.gov/reading-rm/doccollections/commission/secys/2010/secy2010-0043/2010-0043scy.html.

NTI (Australian Nuclear Threat Initiative). 2003a. Russia: Mayak Radioactive Waste Facilities. produced by the James Martin Center for Nonproliferation Studies (CNS), Monterey Institute of International Studies. (July 17). Available at http://www.nti.org/db/nisprofs/russia/fissmat/pumayak/nucwaste.htm.

NTI. 2003b. Russia: Radon. produced by the CNS, Monterey Institute of International Studies. (July 22). Available at http://www.nti.org/db/nisprofs/russia/reactor/waste/radon.htm.

NTI. 2007. Russia: Naval Nuclear Reactors. produced by the CNS, Monterey Institute of International Studies. (January 19). Available at http://www.nti.org/db/nisprofs/russia/naval/overview.htm.

NTI. 2008. Ukraine Profile: Spent Fuel and Radioactive Waste/Developments. produced by the CNS, Monterey Institute of International Studies. (December). Available at http://www.nti.org/e research/profiles/Ukraine/Nuclear/chronology spent fuel waste.html.

NTI. 2010. Russia: Spent Fuel and Radioactive Waste, produced by the CNS, Monterey Institute of International Studies. (March). Available at http://www.nti.org/db/nisprofs/russia/naval/waste/wasteovr.htm 
NTI. 2011a. Australia Profile. produced by the CNS, Monterey Institute of International Studies. (April). Available at http://www.nti.org/e research/profiles/Australia/index.html.

NTI. 2011b. South Korea: Nuclear Overview. produced by the CNS, Monterey Institute of International Studies. (April). Available at http://www.nti.org/e research/profiles/SKorea/Nuclear/index.html.

NUKEM Technologies. 2010. Industrial Complex for Solid Radwaste Management (ICSRM) at Chernobyl Nuclear Power Plant. Project Description. Available at http://www.nukemtechnologies.com/fileadmin/user upload/ICSRM 2010.pdf.

OECD-NEA (Organization for Economic Cooperation and Development - Nuclear Energy Agency). 2005. "Country Profile: Korea," In Radioactive Waste Management Programs in OCED/NEA Member Countries. Available at http://www.oecdnea.org/rwm/profiles/Korea profile web.pdf.

OECD-NEA. 2009a. "Country Profile: Australia," In Radioactive Waste Management Programs in OCED/NEA Member Countries. Available at http://www.oecdnea.org/rwm/profiles/Australia profile web.pdf.

OECD-NEA. 2009b. "Country Report: Radioactive Waste Management and Decommissioning in Sweden," In Radioactive Waste Management Programs in OCED/NEA Member Countries. Available at http://www.oecd-nea.org/rwm/profiles//Sweden report web 2009.pdf.

OECD-NEA. 2010a. "Country Profile: Belgium," In Radioactive Waste Management Programs in OCED/NEA Member Countries. Available at http://www.oecdnea.org/rwm/profiles/Belgium\%20profile\%202010\%20web.pdf.

OECD-NEA. 2010b. "Country Profile: Sweden," In Radioactive Waste Management Programs in OCED/NEA Member Countries. Available at http://www.oecdnea.org/rwm/profiles//Sweden\%20profile\%202010\%20web.pdf.

OECD-NEA. 2010c. "Country Profile: United Kingdom," In Radioactive Waste Management Programs in OCED/NEA Member Countries. Available at http://www.oecdnea.org/rwm/profiles/United\%20Kingdom\%20profile\%202010\%20web.pdf.

OECD-NEA. 2010d. "Country Report: Radioactive Waste Management and Decommissioning in the United Kingdom: National Framework for Management and Regulation of Radioactive Waste and Decommissioning," In Radioactive Waste Management Programs in OCED/NEA Member Countries. Available at http://www.oecdnea.org/rwm/profiles/United\%20Kindgom\%20Report\%202010\%20web.pdf.

OECD-NEA. 2010e. "Country Report: Radioactive Waste Management in Rep. of Korea," In Radioactive Waste Management Programs in OCED/NEA Member Countries. Available at http://www.oecd-nea.org/rwm/profiles/Korea\%20report\%202010\%20web.pdf.

Olsson, O., T. Hedman, B. Sundman, and C. Svemar. 2008. Geological disposal of radioactive waste-Experience from operating facilities in Sweden. Reviews in Engineering Geology. 19:73-80. 
ONDRAF/NIRAS (Belgian Agency for Radioactive Waste and Enriched Fissile Materials). 2006. The disposal on Belgian territory of short-lived low-level and medium-level radioactive waste: Final report by ONDRAF/NIRAS for the period 1985-2006 inviting the Federal Government to decide on the continuation of the disposal programme. NIROND 2006-02 E. Brussels, Belgium. (May). Available at http://www.ondraf.be/engels/PDF/Final report cat A 99 final text.pdf

ONDRAF/NIRAS. 2007. The concept of surface disposal in Dessel for category A waste. Brussels, Belgium. (November). Available at http://www.ondraf.be/engels/PDF/Fiche 5 E.pdf

ONDRAF/NIRAS. 2011. Inventory of radioactive waste. Agency website. Available at http://www.nirond.be/engels/7.8 Inventaris eng.html\#waste

Orr, K. 2007. "Canadian experience in seeking community support for a deep geologic Repository," In Low and Intermediate Level Waste Repositories: Socioeconomic Aspects and Public Involvement, Proceedings of a workshop. International Atomic Energy Agency (IAEA). Waste Technology Section. Vienna, Austria. IAEA-TECDOC-1553. (June). Available at http://www-pub.iaea.org/MTCD/publications/PDF/te 1553 web.pdf.

Owen, J. 2010. Photos: Leaking Nuclear Waste Fills Former Salt Mine. National Geographic photographs. (July 8). Available at http://news.nationalgeographic.com/news/2010/07/photogalleries/100708-radioactive-nuclearwaste-science-salt-mine-dump-pictures-asse-ii-germany/\#/salt-mine-nuclear-waste-assegermany-loader-barrels 23154 600x450.jpg.

Park, H.S. 1999. "The Status of the radioactive waste management in Korea," In Proceedings of the International Symposium on Technologies for the Management of Radioactive Waste from Nuclear Power Plants and Back End Nuclear Fuel Cycle Activities. IAEA-SM-357. Taejon, Republic of Korea. (August 30 - September 3). Available at http://wwwpub.iaea.org/MTCD/publications/PDF/csp 006c/PDF-Files/paper-62.pdf.

Park, J.B., H. Jung, E.Y. Lee, C.L. Kim, G.Y. Kim, K.S. Kim, et al. 2009. Wolsong Low- and Intermediate-Level Radioactive Waste Disposal Center: Progress and Challenges. Nuclear Engineering and Technology, Special Issue in Celebration of the 40th Anniversary of the Korean Nuclear Society. 41(4):477-492. (May). Available at http://article.nuclear.or.kr/jknsfile/v41/JK0410477.pdf.

Paschoa, A.S., A. Tranjan Filho, and J.J. Rosenthal. 1993. Revisiting Goiania: Toward a final repository for radioactive waste. IAEA Bulletin. 35(1):28-31. Available at http://www.iaea.org/Publications/Magazines/Bulletin/Bull351/35105892831.pdf.

Perovskiy, V.A. 2011. "Where To Get Radioactive Waste For Sayda," In Russia's Nuclear Waste Handling Program Examined. Open Source Center (article from St. Petersburg ProAtom.ru in Russian). (February 18).

PHAI (Port Hope Area Initiative). 2011. Project website. Available at http://www.phai.ca/en/phaihome. 
PNGMDR (Plan National de Gestion des Matières et des Déchets Radioactifs, or French National Plan for Management of Radioactive Materials and Waste). 2006. National Radioactive Material and Waste Management Plan: 2007 - 2009. Version 7. République Française. (January 26). Available at http://www.asn.fr/index.php/content/download/15566/100913/Radioactive Material Waste.pdf.

Pöyry Energy Limited. 2011. The 2010 UK Radioactive Waste Inventory: A Summary of Information for International Reporting. prepared for the UK Department of Energy \& Climate Change (DECC) and the Nuclear Decommissioning Authority (NDA). URN 10D/987, NDA/ST/STY(11)006. (February). Available at http://www.nda.gov.uk/ukinventory/documents/Reports/upload/2010-UK-Radioactive-WasteInventory-A-Summary-of-Information-for-International-Reporting.pdf.

Purtov, O., P. Rusinko, L. Litvinsky, and A. Masko. 2007. "Ukraine: Decommissioning Waste Management Strategy in Ukraine," In Disposal Aspects of Low and Intermediate Level Decommissioning Waste: Results of a coordinated research project 2002-2006. CD-ROM. IAEA-TECDOC-1572. (December). Available at http://www-pub.iaea.org/MTCD/publications/PDF/TE 1572 companion CD web.pdf.

Raj, K., K.K. Prasad, and N.K. Bansal. 2006. Radioactive waste management practices in India. Nuclear Engineering and Design. 236(7-8):914-930. (April).

Ramana, M.V., D.G. Thomas, and S. Varughese. 2001. Estimating nuclear waste production in India. Current Science: 81(11, 10). (December). Available at www.ias.ac.in/currsci/dec102001/1458.pdf.

Republica Argentina. 2008. Joint Convention on the Safety of Spent Fuel Management and on the Safety of Radioactive Waste Management, Third National Report. Available at http://www.cnea.gov.ar/xxi/residuos/en/THIRD\%20NATIONAL\%20REPORT\%20DV.pdf

République Française. 2008. France, Third National Report on Compliance with the Joint Convention Obligations. Joint Convention for the Safety of Spent Fuel Management and on the Safety of Radioactive Waste Management. (September). Available at http://www.french-nuclearsafety.fr/index.php/content/download/15546/100853.

République Française . 2010. France: Convention on Nuclear Safety, Fifth National Report for the 2011 Peer Review Meeting. (July). Available at http://www.french-nuclearsafety.fr/index.php/content/download/27163/163366.

Rieke, J. 2010. Satellite image map of Mayak. Color correction, borders, and labels of a NASA World Wind screenshot (Landsat Global Mosaic visual layer). (April 30). Available at http://commons.wikimedia.org/wiki/File:Satellite image map of Mayak.jpg.

Russian Federation. 2006. First National Report of the Russian Federation on compliance with the obligations of the Joint Convention on the Safety of Spent Fuel Management and the Safety of Radioactive Waste Management. Prepared for the Second Review Meeting in frames of the Joint Convention on the Safety of Spent Fuel Management and the Safety of Radioactive Waste Management. Moscow, Russia. Available at http://wwwns.iaea.org/downloads/rw/conventions/russian-federation-national-report.pdf. 
Russian Federation. 2008. Second National Report of the Russian Federation on compliance with the obligations of the Joint Convention on the Safety of Spent Fuel Management and the Safety of Radioactive Waste Management. Prepared for the Third Review Meeting in frames of the Joint Convention on the Safety of Spent Fuel Management and the Safety of Radioactive Waste Management. Moscow, Russia. Available at http://www.vatesi.It/fileadmin/documents/Ataskaitos/Rusijos.pdf.

Sailer, M. 2008. Nuclear waste repository case studies: Germany. Nuclear waste repository case studies. Bulletin of the Atomic Scientists. (August 29). Available at http://www.thebulletin.org/web-edition/reports/nuclear-waste-repository-case-studies/nuclearwaste-repository-case-studies-germ.

SC Rosatom (State Atomic Energy Corporation of Russia). 2011. Agency website. Available at http://www.rosatom.ru/wps/wcm/connect/rosatom/rosatomsite.eng/

Schechter, D., 2011. West Texas facility ready for nuclear waste. Texas News. WFAA website. (February 8). Available at http://www.wfaa.com/news/texas-news/West-Texas-facility-ready-fornuclear-waste-115543929.html.

Schwarz, T. 2010. Salt Cave. National Geographic photographs. (July 8). Available at http://news.nationalgeographic.com/news/2010/07/photogalleries/100708-radioactive-nuclearwaste-science-salt-mine-dump-pictures-asse-ii-germany/\#/salt-mine-nuclear-waste-assegermany-salt-mine 23157 600x450.jpg.

SE RAW (Bulgaria State Enterprise Radioactive Waste). 2011. Report on Environmental Impact Assessment EIAR on Investment Proposal for Construction of National Repository for Low and Intermediate Level Radioactive Waste Disposal - NRRAW. prepared by Eco Energoproekt LTD. (January). Available at

http://www.mmediu.ro/protectia mediului/evaluare impact/13.04.2011 Kozlodui/EIA report ND F.pdf.

SKB (Svensk Kärnbränslehantering AB, or Swedish Nuclear Fuel and Waste Management Company). 2006. SFR: Final Repository for Radioactive Operational Waste. Stockholm, Sweden. (February). Available at http://www.skb.se/upload/publications/pdf/Engelsk low res.pdf.

SKB. 2009. Annual Report. Stockholm, Sweden. Available at http://www.skb.se/upload/publications/pdf/SKB Verksamhet 2009 Engelsk web.pdf.

SKB. 2011a. Final repository for short-lived radioactive waste. Company website. Available at http://www.skb.se/Templates/Standard 25485.aspx.

SKB. 2011b. The M/S Sigyn. Company website. Available at http://www.skb.se/Templates/Standard 25490.aspx.

SNRCU (State Nuclear Regulatory Committee of Ukraine). 2003. Ukraine National Report: Document developed in Compliance with the Joint Convention on the Safety of Spent Fuel Management and on the Safety of Radioactive Waste Management. Kyiv, Ukraine. (April 29). Available at http://www.snrc.gov.ua/nuclear/doccatalog/document;jsessionid=958478B2B63AF0B4586350C 500E8C685?id=52829. 
SNRCU. 2005. Nuclear and Radiation Safety in Ukraine Annual Report 2005. Kyiv, Ukraine. Available at http://www.snrc.gov.ua/nuclear/doccatalog/document?id=52833.

SNRCU. 2007. Fourth National Report of Ukraine on Compliance with the Obligations of the Convention on Nuclear Safety. Kyiv, Ukraine. (September). Available at http://www.snrc.gov.ua/nuclear/doccatalog/document?id=75135.

SNRCU. 2008. National Report: On Compliance with the Obligations under the Joint Convention on the Safety of Spent Fuel Management and on the Safety of Radioactive Waste Management. Kyiv, Ukraine. (September). Available at http://www.snrc.gov.ua/nuclear/doccatalog/document?id=119923.

SNRCU. 2009. Nuclear and Radiation Safety in Ukraine Annual Report 2009. Kyiv, Ukraine. Available at http://www.snrc.gov.ua/nuclear/doccatalog/document?id=132443.

Soda, Kunihisa, Laszlo Koblinger, and Frank Marcinowski, 2009. Joint Convention on the Safety of Spent Fuel Management and on the Safety of Radioactive Waste Management, Third Review Meeting of the Contracting Parties, Summary Report, JC/RM3/02/Rev 2, Vienna, Austria, May. Available at http://www-ns.iaea.org/downloads/rw/conventions/third-review-meeting/final-report-english.pdf.

STOLA (Studie- en Overleggroep Laagactief Afval Dessel, or Dessel Study and Consultation Group on Low-Level Waste). 2004. Belgian Low-Level and Short-Lived Waste: Does It Belong In Dessel? An integrated disposal project with technical and social implications. Dessel, Belgium. (November). Available at http://www.stora.org/assets/stola/publicaties/bergingsproject\%20eng.pdf.

STORA (Studie- en Overleggroep Radioactief Afval Dessel, or Dessel Study and Consultation Group on Radioactive Waste). 2011. Association website. Available at http://www.stora.org/default.asp.

Sumi, Y., and Y. Matsuo, 2005, Nuclear Fuel Recycling and Waste Management in Japan, NARUC Summer Meeting in Austin, Texas (July 25). Available at http://www.narucmeetings.org/Presentations/nucwaste Matsuo s05.pdf.

Sweden. 2008. Sweden's Third National Report under the Joint Convention for the Safety of Spent Fuel Management and on the Safety of Radioactive Waste Management: Swedish implementation of the obligations of the Joint Convention. Ministry of the Environment.

Ds 2008:73. Stockholm, Sweden. Available at http://www.regeringen.se/content/1/c6/11/80/02/4e35cfc4.pdf.

Texas Register. 2010. Title 31. Natural Resources and Conservation Part, 21. Texas Low Level Radioactive Waste Disposal Compact Commission, Chapter 675. Preliminary Rules, Subchapter B. Exportation and Importation of Waste. 31 TAC \$§ 675.21-23. 35 (7):961-1384. (February 12). Available at http://www.tllrwdcc.org/pdf/Subchp\%20B\%20in\%20TR\%20published\%20100212.pdf.

Thomson, C. 2009. Radwaste management: Mixing it up. Nuclear Engineering International, Global Trade Media. (July 27). Available at http://www.neimagazine.com/story.asp?sectionCode=76\&storyCode=2053685. 
TX CEQ (Texas Commission on Environmental Quality). 2009. Radioactive Material License. Licensee: Waste Control Specialists, LLC. License Number: R04100. (Sept. 10)

TLLRWDCC (Texas Low-Level Radioactive Waste Disposal Compact Commission). 2010. 31 TAC §§ 675.21-23 - Committee Draft. (April 29).

Van Zaelen, G., and C. Cosemans. 2005. Waste Inventory Record Keeping Systems (WIRKS) in Belgium. ONDRAF/NIRAS Workshop. Brussels, Belgium. (August 28-31). Available at http://newmdb.iaea.org/GetLibraryFile.aspx?RRoomID=554.

Voizard, P., 2006, Morvilliers Very-Low-Level Waste Facility - Experience Gained After Two Years Of Operation, presented at CEG workshop on "Isolation and Disposal of Radioactive Waste." Olkiluoto, Finland. (June 28-30). Available at http://www.iaea.org/OurWork/ST/NE/NEFW/CEG/documents/ws062006 18E.pdf.

WA DOH (Washington State Department of Health). 2005. Commercial Low Level Radioactive Waste Disposal. Division of Environmental Health, Office of Radiation Protection. Agency website. Available at http://www.doh.wa.gov/EHP/rp/waste/llwhm.htm.

Wen, Z., and Z. Liu. 2007. "Feasibility Study of the Option of On-Site Disposal of Decommissioned Nuclear Wastes in China." In Low and Intermediate Level Waste Repositories: Socioeconomic Aspects and Public Involvement, Proceedings of a workshop. International Atomic Energy Agency (IAEA). Waste Technology Section. Vienna, Austria. IAEA-TECDOC1553. (June). Available at http://www-pub.iaea.org/MTCD/publications/PDF/te 1553 web.pdf.

WNA (World Nuclear Association). 2007. Radioactive waste repository \& store for Australia. (October). Available at http://www.world-nuclear.org/info/inf72.html.

WNA. 2010. Nuclear Power in Armenia. (August 21). Available at http://www.worldnuclear.org/info/inf113.html.

WNA. 2010. Radioactive Waste Management - Appendix 2: Storage and Disposal Options, (November). Available at http://www.world-nuclear.org/info/inf04ap2.html.

WNA. 2011a. China's Nuclear Fuel Cycle. (July 28). Available at http://www.worldnuclear.org/info/inf63b china nuclearfuelcycle.html.

WNA. 2011b. Emerging Nuclear Energy Countries, (September). Available at http://www.worldnuclear.org/info/inf102.html.

WNA. 2011c. International Nuclear Waste Disposal Concepts. (June). Available at www.worldnuclear.org/info/inf21.html.

WNA. 2011d. Nuclear Power in Argentina (August). Available at http://www.worldnuclear.org/info/inf96.html.

WNA. 2011e. Nuclear Power in Belgium. (June). Available at http://www.worldnuclear.org/info/inf94.html. 
WNA. 2011f. Nuclear Power in Brazil. (March). Available at http://www.worldnuclear.org/info/inf95.html.

WNA. 2011g. Nuclear Power in Bulgaria. (July). Available at http://www.worldnuclear.org/info/inf87.html.

WNA. 2011h. Nuclear Power in Canada. (August). Available at http://www.worldnuclear.org/info/inf49a Nuclear Power in Canada.html.

WNA. 2011i. Nuclear Power in China. (September 15). Available at http://www.worldnuclear.org/info/inf63.html.

WNA. 2011j. Nuclear Power in China Appendix 1: Government Structure and Ownership. (July). Available at http://www.world-nuclear.org/info/inf63ai chinanuclearstructure.html.

WNA. 2011k. Nuclear Power in France. (July 26). Available at http://www.worldnuclear.org/info/inf40.html.

WNA. 2011I. Nuclear Power in Germany. (August). Available at http://www.worldnuclear.org/info/inf43.html.

WNA. $2011 \mathrm{~m}$. Nuclear Power in India. (September). Available at http://www.worldnuclear.org/info/inf53.html.

WNA. 2011n. Nuclear Power in Japan. (September). Available at http://www.worldnuclear.org/info/inf79.html.

WNA. 20110. Nuclear Power in Russia. (August). Available at http://www.worldnuclear.org/info/inf 45. html.

WNA. 2011p. Nuclear Power in South Korea. (August 1). Available at http://www.worldnuclear.org/info/inf81.html.

WNA. 2011q. Nuclear Power in Sweden. (August 22). Available at http://www.worldnuclear.org/info/inf42.html.

WNA. 2011r. Nuclear Power in the United Kingdom. (August 16). Available at http://www.worldnuclear.org/info/inf84.html.

WNA. 2011s. Nuclear Power in the United Kingdom: Appendix 1. (June). Available at http://www.world-nuclear.org/info/inf84a nuclear development UK.html.

WNA. 2011t. Nuclear Power in Ukraine. (August). Available at http://www.worldnuclear.org/info/inf $46 . \mathrm{html}$.

WNA. 2011u. Nuclear Power in the USA. (September). Available at http://www.worldnuclear.org/info/inf $41 . \mathrm{html}$.

WNA. 2011v. Radioactive Waste Management. (July). Available at http://www.worldnuclear.org/info/inf04.html. 
WNA. 2011w. Radioactive Waste Management - Appendix 3: National Policies. (July). Available at http://www.world-nuclear.org/info/inf04ap3.html.

WNA. 2011x. Radioactive Waste Management - Appendix 4: National Funding. (July). Available at http://www.world-nuclear.org/info/inf04ap4.html.

WNA. 2011y. Russia's Nuclear Fuel Cycle. (July). Available at http://www.worldnuclear.org/info/inf45a Russia nuclear fuel cycle.html.

WNA. 2011z. US Nuclear Power Policy. (August). Available at http://www.worldnuclear.org/info/inf41 US nuclear power policy.html.

WNN (World Nuclear News). 2008. Energy Solutions' Italian job. Waste and Recycling section. Available at http://www.world-nuclear-news.org/WR-

Energy Solutions Italian job 1305082.html.

Xiande, W. 1999. "National Strategy and Practice for Disposal of Radioactive Waste in China," In Proceedings of the International Symposium on Technologies for the Management of Radioactive Waste from Nuclear Power Plants and Back End Nuclear Fuel Cycle Activities. IAEA-SM-357. Taejon, Republic of Korea. (August 30 - September 3). Available at http://wwwpub.iaea.org/MTCD/publications/PDF/csp 006c/PDF-Files/paper-13.pdf.

Zarafyan, I. 2010. We Have New Nuclear Policy? EcoLur: New Informational Policy in Ecology website. (June 29). Available at http://www.ecolur.org/en/news/nuclear-energy/we-have-newnuclear-policy/1116/.

Ziehm, R., and S.G. Pichurin. 2003. Engineered Near Surface Disposal Facility of the Industrial Complex for Solid Radwaste Management at Chernobyl Nuclear Power Plant. paper presented at the Waste Management Conference. Tucson, AZ. (February 23-27). Available at http://www.wmsym.org/archives/2003/pdfs/152.pdf. 